Prepared in cooperation with the Bureau of Reclamation

\title{
Instream Flow Characterization of Upper Salmon River Basin Streams, Central Idaho, 2003
}

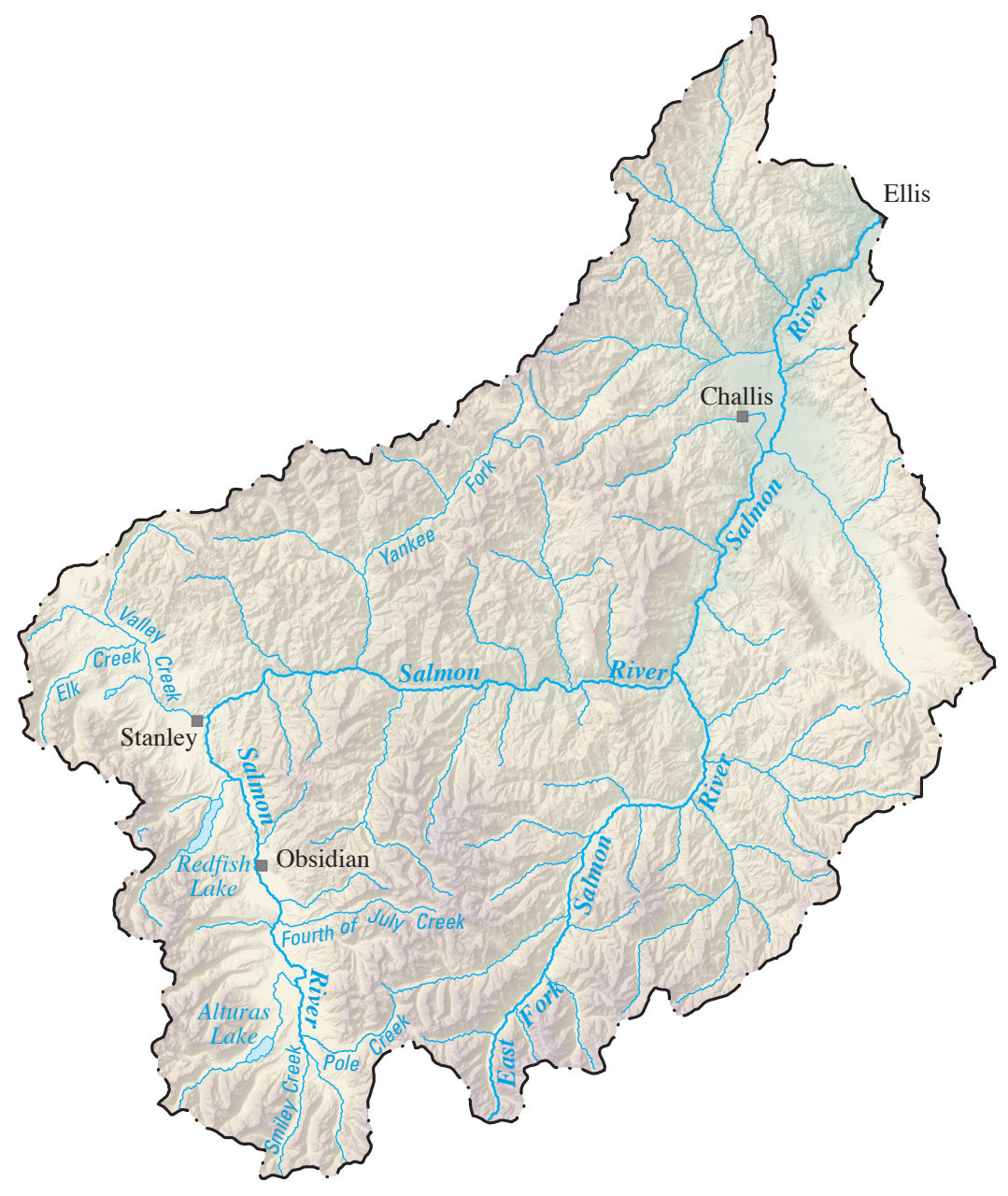

Scientific Investigations Report 2004-5173

Version 1.2 
On July 7, 2005 the following corrections were made to this report (Version 1.2):

Page 9, left column - EA Engineering Science and Technology Incorporated, 1991b changed to $1991 \mathrm{a}$

Page 9, left column - URL corrected

Page 14, figure 1 corrected - correct location for Castle Peak added to large map

Page 18, second reference, left column - spelling of Henriksen corrected

Page 26, Pole Creek section - Temperature in degrees Fahrenheit information removed

Page 45, Fourth of July Creek section - Temperature in degrees Fahrenheit information removed and explanation box in illustration corrected

Page 94, Elk Creek section - Temperature in degrees Fahrenheit information removed

Page 115, Valley Creek section - Temperature in degrees Fahrenheit information removed and explnation box in illustration corrected 


\section{Instream Flow Characterization of Upper Salmon River Basin Streams, Central Idaho, 2003}

By Terry R. Maret, Jon E. Hortness, and Douglas S. Ott

Prepared in cooperation with the Bureau of Reclamation

Scientific Investigations Report 2004-5173

Version 1.2

U.S. Department of the Interior

U.S. Geological Survey 


\section{Instream Flow Characterization of Upper Salmon River Basin Streams, Central Idaho, 2003}

By Terry R. Maret, Jon E. Hortness, and Douglas S. Ott

Prepared in cooperation with the Bureau of Reclamation

Scientific Investigations Report 2004-5173

Version 1.2

U.S. Department of the Interior

U.S. Geological Survey 


\title{
U.S. Department of the Interior \\ Gale A. Norton, Secretary
}

\author{
U.S. Geological Survey \\ Charles G. Groat, Director
}

U.S. Geological Survey, Reston, Virginia: 2004

For more information about the USGS and its products:

Telephone: 1-888-ASK-USGS

World Wide Web: http://www.usgs.gov/

Any use of trade, product, or firm names in this publication is for descriptive purposes only and does not imply endorsement by the U.S. Government.

Although this report is in the public domain, permission must be secured from the individual copyright owners to reproduce any copyrighted materials contained within this report.

Maret, T.R., Hortness, J.E., and Ott, D.S., 2004, Instream Flow Characterization of Upper Salmon River Basin Streams, Central Idaho, 2003: Reston, VA., U.S. Geological Survey Scientific Investigations Report 2004-5173, 158 p.

URLs in the printed version of this report are not complete. Refer to the Web version of this report at http://id.water.usgs.gov/public/reports.html for complete URLs (which are indicated in blue). 


\section{Contents}

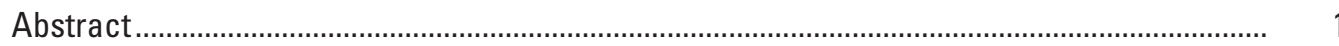

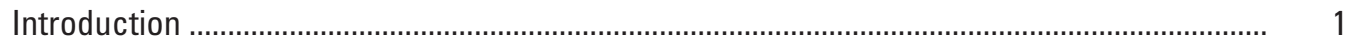

Purpose and Scope …........................................................................................... 3

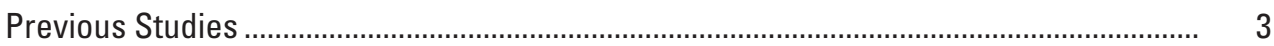

Description of Study Area .................................................................................................... 5

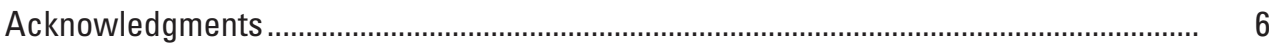

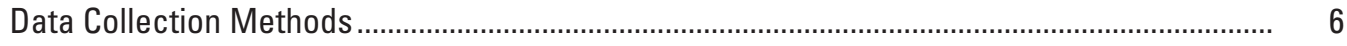

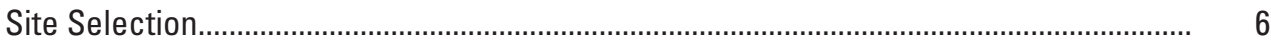

Environmental Variables ....................................................................................................

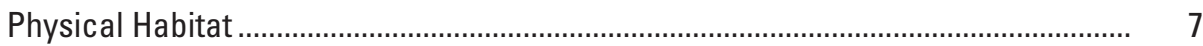

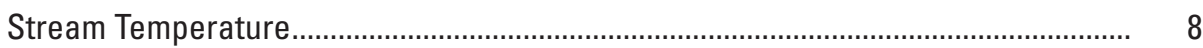

Analytical Methods for Instream Flow Characterization ........................................................... 8

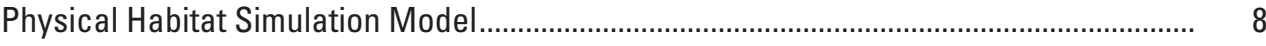

Hydraulic Modeling and Calibration ......................................................................... 8

Habitat Modeling ..................................................................................................... 9

Selection of Target Species and Suitability Criteria ............................................ $\quad 9$

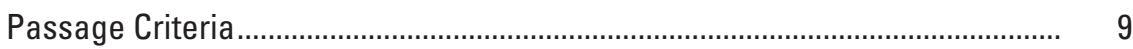

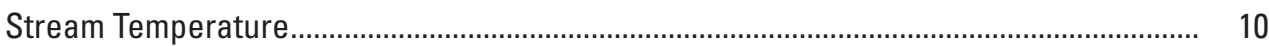

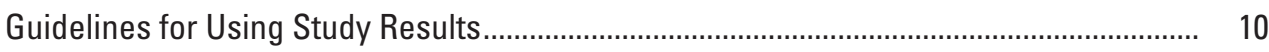

Climatic and Hydrologic Conditions During 2003 ….............................................................. 11

Climatic Conditions .................................................................................................... 12

Hydrologic Conditions ............................................................................................... 12

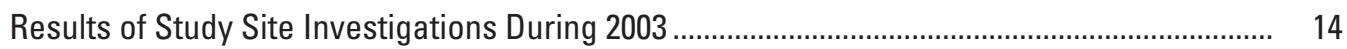

Pole Creek Section ..................................................................................................... 21

Pole Creek ................................................................................................... 22

Hydrology During 2003 ..................................................................................... 22

Habitat Modeling and Passage Results ................................................................... 24

Stream Temperature Results ............................................................................ $\quad 25$

Pole Creek Appendix Abbreviations ........................................................................ 26

Fourth of July Creek Section...................................................................................... 40

Fourth of July Creek ............................................................................................. 41

Hydrology During 2003 .................................................................................... 41

Habitat Modeling and Passage Results ................................................................ 42

Stream Temperature Results .............................................................................. 44

Fourth of July Creek Appendix Abbreviations ...................................................... 46

Elk Creek Section ................................................................................................... 90

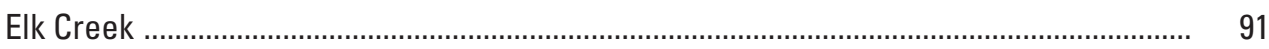

Hydrology During 2003 ................................................................................. 91

Habitat Modeling and Passage Results ................................................................ 93

Stream Temperature Results ............................................................................. 94

Elk Creek Appendix Abbreviations..................................................................... 95

Valley Creek Section .......................................................................................... 110

Valley Creek ..................................................................................................................... 111

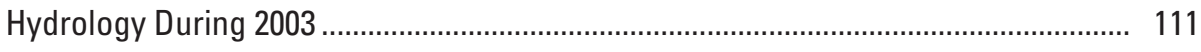

Habitat Modeling and Passage Results .............................................................. 113

Stream Temperature Results .................................................................................. 114

Valley Creek Appendix Abbreviations ................................................................. 116

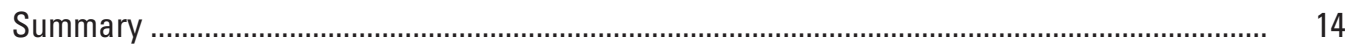

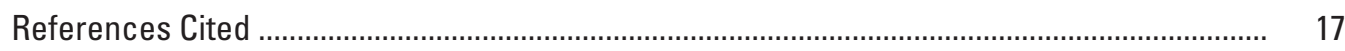




\section{Figures}

1. Location of upper Salmon River Basin, Idaho …….................................................... 4

2. Hierarchical mesohabitat classification .................................................................... 7

3. Mean daily air temperature for period June through September 2003 in relation to long-term (1971 through 2000) mean daily temperature measured at Stanley Ranger Station, upper Salmon River Basin, Idaho.....

4. Pole Creek study site, diversion, and gaging station location, upper Salmon River Basin, Idaho, 2003.

5. Daily mean discharge at upper Pole Creek below Pole Creek Ranger Station near Obsidian (13292380), upper Salmon River Basin, Idaho, June 1 through September 30, 2003

6. Daily mean discharge for water year 2003 , estimated long-term daily mean discharge, and estimated 80-, 50-, and 20-percent exceedance statistics for upper Pole Creek below Pole Creek Ranger Station near Obsidian (13292380), upper Salmon River Basin, Idaho, July 1 through September 30

7. Maximum daily water temperature for period June 25 through September 28, 2003, at Pole Creek, upper Salmon River Basin, Idaho

8. Fourth of July Creek study sites, diversions, and gaging station locations, upper Salmon River Basin, Idaho, 2003.

9. Daily mean discharge at Fourth of July Creek upstream from diversions near Obsidian (13293350), upper Salmon River Basin, Idaho, June 1 through September 30, 2003

10. Daily mean discharge for water year 2003 , estimated long-term daily mean discharge, and estimated 80-, 50-, and 20-percent exceedance statistics for Fourth of July Creek upstream from diversions near Obsidian (13293350), upper Salmon River Basin, Idaho, July 1 through September 30

11. Maximum daily water temperature for period June 25 through September 28, 2003, at Fourth of July Creek, upper Salmon River Basin, Idaho

12. Elk Creek and Valley Creek study sites, diversions, and gaging station locations, upper Salmon River Basin, Idaho, 2003.

13. Daily mean discharge at lower Elk Creek upstream from diversions near Stanley (13294640), upper Salmon River Basin, Idaho, June 1 through September 30, 2003 ... 91

14. Daily mean discharge for water year 2003 , estimated long-term daily mean discharge, and estimated 80-, 50-, and 20-percent exceedance statistics for Elk Creek upstream from diversions near Stanley (13294640), upper Salmon River Basin, Idaho, July 1 through September 30 ...

15. Maximum daily water temperature for period June 19 through September 29, 2003,

at Elk Creek, upper Salmon River Basin, Idaho.

16. Daily mean discharge at Valley Creek upstream from diversions near Stanley

(13294600), upper Salmon River Basin, Idaho, May 1 through September 30, 2003 .... 111

17. Daily mean discharge for water year 2003 , estimated long-term daily mean discharge, and estimated 80-, 50-, and 20-percent exceedance statistics for Valley Creek upstream from diversions near Stanley (13294600), upper Salmon River Basin, Idaho, July 1 through September 30

18. Maximum daily water temperature for period June 19 through September 29, 2003, at Valley Creek, upper Salmon River Basin, Idaho (site VC1 period July 15 through September 29, 2003). 


\section{Tables}

1. Basin and site characteristics for gaging stations, diversions, and study sites in the upper Salmon River Basin, Idaho, 2003.

2. Calculated and estimated 80-, 50-, and 20-percent monthly exceedance discharge values for Pole Creek below Pole Creek Ranger Station near Obsidian (13292380), upper Salmon River Basin, Idaho, 2003

3. Miscellaneous discharge measurements collected on Pole Creek, upper Salmon River Basin, Idaho, 2003

4. Habitat and discharge measurements for upper Pole Creek (PC2), upper Salmon River Basin, Idaho, 2003

5. Calculated and estimated 80-, 50-, and 20-percent monthly exceedance discharge values for Fourth of July Creek upstream from diversions near Obsidian (13293350), upper Salmon River Basin, Idaho, 2003

6. Miscellaneous discharge measurements collected on Fourth of July Creek, upper Salmon River Basin, Idaho, 2002-03

7. Habitat and discharge measurements for upper (JC3), middle (JC2), and lower (JC1) Fourth of July Creek, upper Salmon River Basin, Idaho, 2003

8. Calculated and estimated 80-, 50-, and 20-percent monthly exceedance discharge values for Elk Creek upstream from diversions near Stanley (13294640), upper Salmon River Basin, Idaho, 2003

9. Miscellaneous discharge measurements collected on Elk Creek, upper Salmon River Basin, Idaho, 2003

10. Habitat and discharge measurements for lower Elk Creek (EC1), upper Salmon River Basin, Idaho, 2003

11. Calculated and estimated 80-, 50-, and 20-percent monthly exceedance discharge values for Valley Creek upstream from diversions near Stanley (13294600), upper Salmon River Basin, Idaho, 2003.

12. Miscellaneous discharge measurements collected on Valley Creek, upper Salmon River Basin, Idaho, 2003.

13. Habitat and discharge measurements for upper (VC3), middle (VC2), and lower (VC1) Valley Creek, upper Salmon River Basin, Idaho, 2003 


\section{Conversion Factors and Datum}

\begin{tabular}{lcl}
\hline Multiply & By & To obtain \\
\hline cubic foot per second $\left(\mathrm{ft}^{3} / \mathrm{s}\right)$ & 0.02832 & cubic meter per second $\left(\mathrm{m}^{3} / \mathrm{s}\right)$ \\
foot $(\mathrm{ft})$ & 0.3048 & meter $(\mathrm{m})$ \\
foot per second $(\mathrm{ft} / \mathrm{s})$ & 0.3048 & meter per second $(\mathrm{m} / \mathrm{s})$ \\
inch (in.) & 25.4 & millimeter $(\mathrm{mm})$ \\
mile $(\mathrm{mi})$ & 1.609 & kilometer $(\mathrm{km})$ \\
square mile $\left(\mathrm{mi}^{2}\right)$ & 2.590 & square kilometer $\left(\mathrm{km}^{2}\right)$ \\
\hline
\end{tabular}

Temperature in degrees Celsius $\left({ }^{\circ} \mathrm{C}\right)$ may be converted to degrees Fahrenheit $\left({ }^{\circ} \mathrm{F}\right)$ as follows:

$$
{ }^{\circ} \mathrm{F}=1.8^{\circ} \mathrm{C}+32
$$

Sea level: In this report, "sea level" refers to the National Geodetic Vertical Datum of 1929-a geodetic datum derived from a general adjustment of the first-order level nets of the United States and Canada, formerly called Sea Level Datum of 1929.

Horizontal coordinate information is referenced to the North American Datum of 1983 (NAD83)

Water Year: In U.S. Geological Survey reports dealing with surface-water supply, a water year is the 12-month period, October 1 through September 30. The water year is designated by the calendar year in which it ends; thus, the year ending September 30, 2003, is called the "2003 water year." 


\section{Abbreviations}

$\begin{array}{ll}\text { ASTM } & \text { American Society of Testing and Materials } \\ \text { AVDEPTH/AVPERM } & \text { Hydraulic parameter option in PHABSIM for Windows } \\ \text { BIA } & \text { Bureau of Indian Affairs } \\ \text { CI } & \text { Composite index } \\ \text { ESA } & \text { Endangered Species Act } \\ \text { HABTAE } & \text { Habitat program option in PHABSIM for Windows } \\ \text { IDEO } & \text { Idaho Department of Environmental Quality } \\ \text { IDFG } & \text { Idaho Department of Fish and Game } \\ \text { IFIM } & \text { Instream Flow Incremental Methodology } \\ \text { MAD } & \text { Mean annual discharge } \\ \text { MANSO } & \text { Manning's equation } \\ \text { MDAT } & \text { Maximum daily-average temperature } \\ \text { MDMT } & \text { Maximum daily-maximum temperature } \\ \text { MWMT } & \text { Maximum weekly-maximum temperature } \\ \text { MWAT } & \text { Maximum weekly-average temperature } \\ \text { NOAA } & \text { National Oceanic and Atmospheric Administration } \\ \text { PHABSIM } & \text { Physical Habitat Simulation Model } \\ \text { O.20 } & \text { Daily mean discharge exceeded 20 percent of the time during a } \\ \text { O.50 } & \text { specified month } \\ \text { O.80 } & \text { Daily mean discharge exceeded 50 percent of the time during a } \\ \text { SI } & \text { specified month (same as median discharge) } \\ \text { SNRA } & \text { Daily mean discharge exceeded 80 percent of the time during a } \\ \text { SRA } & \text { specified month } \\ \text { SSTEMP } & \text { Suitability index } \\ \text { STG0 } & \text { Sawtooth National Recreation Area } \\ \text { USEPA } & \text { Snake River Adjudication } \\ \text { USFS } & \text { Stream Segment Temperature Model } \\ \text { USFWS } & \text { Stage-discharge relation } \\ \text { USGS } & \text { U.S. Environmental Protection Agency } \\ \text { WSP } & \text { U.S. Forest Service } \\ \text { WUA } & \text { U.S. Fish and Wildlife Service } \\ \text { WY03 } & \text { U.S. Geological Survey } \\ \text { Water surface profile } \\ \text { Weighted usable area } \\ \text { Water 2003 }\end{array}$




\title{
Instream Flow Characterization of Upper Salmon River Basin Streams, Central Idaho, 2003
}

\author{
By Terry R. Maret, Jon E. Hortness, and Douglas S. Ott
}

\section{Abstract}

Anadromous fish populations in the Columbia River Basin have plummeted in the last 100 years. This severe decline led to Federal listing of chinook salmon (Oncorhynchus tshawytscha) and steelhead trout (Oncorhynchus mykiss) stocks as endangered or threatened under the Endangered Species Act (ESA) in the 1990s. Historically, the upper Salmon River Basin (upstream from the confluence with the Pahsimeroi River) in Idaho provided migration corridors and significant habitat for these ESA-listed species, in addition to the federally listed bull trout (Salvelinus confluentus). Human development has modified the original streamflow conditions in many streams in the upper Salmon River Basin. Summer streamflow modifications, as a result of irrigation practices, have directly affected the quantity and quality of fish habitat and also have affected migration and (or) access to suitable spawning and rearing habitat for these fish.

As a result of these ESA listings and Action 149 of the Federal Columbia River Power System Biological Opinion of 2000, the Bureau of Reclamation was tasked to conduct streamflow characterization studies in the upper Salmon River Basin to clearly define habitat requirements for effective species management and habitat restoration. These studies include the collection of habitat and streamflow information for the Physical Habitat Simulation (PHABSIM) model, a widely applied method to determine relations between habitat and discharge requirements for various fish species and life stages. Model results can be used by resource managers to guide habitat restoration efforts in the evaluation of potential fish habitat and passage improvements by increasing streamflow.

Instream flow characterization studies were completed on Pole, Fourth of July, Elk, and Valley Creeks during 2003. Continuous streamflow data were collected upstream from all diversions on each stream. In addition, natural summer streamflows were estimated for each study site using regression equations.

PHABSIM results are presented for bull trout, chinook salmon, and steelhead trout over a range of summer streamflows. Habitat/discharge relations are summarized for juvenile, adult, and spawning life stages at each study site. Adult fish passage and discharge relations are evaluated at specific transects identified as a potential low-streamflow passage barrier at each study site. Continuous summer water temperature data for selected study sites also are summarized and compared with Idaho Water Quality Standards and various temperature requirements of targeted fish species.

Results of these habitat studies can be used to prioritize and direct cost-effective actions to improve fish habitat for ESA-listed anadromous and native fish species in the basin. These actions may include acquiring water during critical low-flow periods by leasing or modifying irrigation delivery systems to minimize out-of-stream diversions.

\section{Introduction}

Rivers, streams, and lakes in the upper Salmon River Basin (defined as the area upstream from the confluence with the Pahsimeroi River) historically provided migration corridors and significant spawning and rearing habitat for anadromous Snake River spring/summer chinook salmon (Oncorhynchus tshawytscha), sockeye salmon (Oncorhynchus nerka), and steelhead trout (Oncorhynchus mykiss). Wild salmon and steelhead in the basin migrate nearly $900 \mathrm{mi}$ between the mountain streams at elevations of 7,000 ft or more where they spawn, hatch, and rear, and the Pacific Ocean where they mature to adulthood. High-elevation spawning and rearing and extensive migration represent a life-history strategy unique among Columbia River chinook salmon and steelhead and may be very important for the long-term survival of these species.

However, anadromous fish populations in the Columbia River Basin have plummeted in the last 100 years (Chapman, 1986; Thurow, 2000; Thurow and others, 2000). This severe decline led to Federal listing of these salmon and steelhead stocks as endangered or threatened under the Endangered Species Act (ESA) in the 1990s. Most remaining populations are severely depressed; fewer than 2 percent of the watersheds in the Columbia River Basin are classified as supporting strong, wild populations of steelhead trout or chinook salmon (Thurow and others, 2000). In addition, at least 214 stocks of 
anadromous salmonids are on the decline or at risk of extinction in the Pacific Northwest and California (Nehlsen and others, 1991).

Wild salmon and steelhead continue to migrate into the upper Salmon River Basin and depend on available spawning and rearing habitat. Resident bull trout (Salvelinus confluentus) also inhabit many of the rivers and streams. However, human development has modified the original streamflow conditions in many streams in the basin. Summer streamflow modifications (July through September) have directly affected the quantity and quality of fish habitat and also have affected migration and (or) access to suitable spawning and rearing habitat for these fish (Munther, 1974; Scott and others, 1981).

Reduced streamflows resulting from diversions also may contribute to increased water temperatures that may be unsuitable for native salmonids in the Sawtooth National Recreation Area (SNRA; M. Moulton, U.S. Forest Service, oral commun., 2003). Stream temperatures vary both spatially, throughout a stream, and temporally, over time. Many factors, both natural and human, can affect stream temperature. Water temperatures are controlled naturally by interactions between solar radiation, ambient air temperature, streamflow, channel geomorphology, and riparian vegetation. There is a natural tendency for stream temperature to increase as water travels downstream. Human activities such as the removal of riparian shading and the alteration of streamflow can accentuate this increase in water temperature.

In general, high water temperatures coincide with high ambient air temperatures and usually occur during the months of July and August. It also is at this time that diversions of streamflow for agricultural purposes are at their highest and streamflows are generally at their lowest. This reduction in streamflow, coupled with high ambient air temperatures, can have severe negative effects on the distribution, health, and survival of coldwater fish species.

Most Pacific Northwest fish are ectothermic (coldblooded), and their survival depends on water temperatures that are within their optimal range. When water temperature exceeds an organism's optimal range, the organism can experience adverse health effects such as reduced growth or increased susceptibility to disease (Countant, 1976; Beitinger and others, 2000; McCullough and others, 2001; Sauter and others, 2001; Selong and others, 2001). Different species have unique temperature requirements, and an individual species may have a unique temperature requirement for each of its life stages. For example, salmonids require varying temperatures to initiate and carry out spawning, incubation, juvenile growth, and adult migration activities (Poole and others, 2001). For chinook salmon, optimal water temperatures range between $10.0^{\circ}$ and $17.0^{\circ} \mathrm{C}$. Adult spawning activities are triggered at water temperatures between $7.0^{\circ}$ and $14.0^{\circ} \mathrm{C}$. Water temperatures above $21.0^{\circ} \mathrm{C}$ can create thermal barriers that can block adult migration to spawning grounds. These thermal barriers can be created by diverting streamflow for irrigation during the summer when air temperatures are at their highest.
Exposure to water temperatures greater than $21.0^{\circ} \mathrm{C}$ for more than 1 week is usually fatal to adult chinook salmon, whereas constant temperatures above $16.0^{\circ} \mathrm{C}$ have been shown to be intolerable for bull trout (Poole and others, 2001). Ott and Maret (2003) predicted a higher probability of bull trout occurrence in streams in the Salmon River Basin where daily maximum temperatures are $10.0^{\circ}$ to $15.0^{\circ} \mathrm{C}$. Passage of bull trout into tributary streams to spawn in late summer may be decreased when temperatures exceed $13.0^{\circ} \mathrm{C}$ and may be potentially blocked when water temperatures exceed $18.0^{\circ} \mathrm{C}$ (J. Dunham, U.S. Forest Service, written commun., 2004).

The Bureau of Reclamation (Reclamation) was tasked through Reasonable and Prudent Alternative Action 149 of the Federal Columbia River Power System Biological Opinion of 2000 to address streamflow deficiencies in 16 priority subbasins in the Columbia River Basin (National Oceanic and Atmospheric Administration, 2000). Flow characteristic studies were undertaken to evaluate streamflow requirements of ESA-listed fish. Results of these studies will be used to prioritize and direct cost-effective actions to improve fish habitat for ESA-listed anadromous and native fish species in the basin. These actions may include acquiring water during critical low-flow periods by leasing or modifying irrigation delivery systems to minimize out-of-stream diversions. Reclamation considers flow characterization studies an integral part of the information needed to correct flow deficiencies within the 10year timeframe allotted for work in each subbasin (Spinazola, 2002).

Many landowners; Federal, State, and Tribal governments; and other local and private parties have completed or are completing projects to maintain, improve, and restore riparian habitat, water quality, fish passage, and other environmental conditions important to protect and restore ESA-listed anadromous and native fish species in the basin (Spinazola, 2002). In addition, the Idaho Department of Fish and Game (IDFG) has completed annual redd counts and fish population assessments on the upper Salmon River and many of its major tributaries (P. Murphy, Idaho Department of Fish and Game, oral commun., 2003). The livelihoods of many of the people who inhabit the basin also depend on streamflows that are used for agricultural, domestic, commercial, municipal, recreational, and other purposes. Formulating an approach to meet the needs of both people and fish rests on understanding how much streamflow is needed by each. The amount of water necessary for different human uses frequently can be determined from readily available information; however, the amount of streamflow necessary to conserve habitat for ESAlisted fish is more difficult to identify because the relevant information for fish is rarely available.

Numerous methods can be used to determine streamflow needs for fish and wildlife (Instream Flow Council, 2002), but one of the most widely used is the Instream Flow Incremental Methodology (IFIM), developed in the 1970s by physical and biological scientists in the U.S. Fish and Wildlife Service (USFWS). IFIM integrates concepts of water-supply planning, analytical hydraulic engineering models, and empirically 
derived habitat/discharge relations to address water-use and instream-flow issues, questions concerning life-stage-specific effects on selected species, and the general well-being of aquatic biological populations. Accepted by many resource managers as an excellent process for establishing habitat/discharge relations, it is the most widely used method in the United States (Instream Flow Council, 2002).

A major component of IFIM is a collection of computer algorithms called the Physical Habitat Simulation Model (PHABSIM). This model incorporates hydrology, stream morphology, and microhabitat preferences to create relations between streamflow and habitat availability (Bovee and others, 1998). Habitat availability is measured by an index called the weighted usable area (WUA), which is the wetted area of a stream weighted by its suitability for use by an organism (expressed as the number of square feet of usable habitat per 1,000 feet of stream). PHABSIM simulates habitat/discharge relations for various species and life stages and allows quantitative habitat comparisons at different discharges of interest.

Streamflow restoration projects developed and completed in the headwaters of the upper Salmon River will provide immediate localized benefits by restoring quality, quantity, and access to important spawning and rearing habitats. As more studies are completed in order of biological priority and more restoration projects are implemented on the basis of streamflow study results, streamflows needed for migration, spawning, and rearing for all fish will be systematically improved. Furthermore, the restored streamflows have the potential for improving spawning and rearing habitat within downstream reaches of the main stem of the Salmon River. Additionally, if the streamflows obtained from these projects are protected from downstream diversion, these benefits are increased by improved conditions for survival throughout the Salmon River migration corridor, thereby improving long-term productivity of the stocks.

\section{Purpose and Scope}

This report summarizes instream flow characterization results for Pole, Fourth of July, Elk, and Valley Creeks in the upper Salmon River Basin of Idaho. Natural streamflows were characterized using continuous summer streamflow data collected upstream from diversions. Comparisons between these data and monthly discharge exceedance estimates, based on regional regression analyses, were reported.

Purposes of this report are to (1) compile, review, and analyze hydrologic and biological data for selected streams; (2) assemble habitat suitability curves for the targeted species and life stages that are needed to perform PHABSIM modeling and analysis; (3) provide instream flow characterization results for selected streams to identify streamflow needs during July through September for fish passage and various life stages of chinook salmon, steelhead trout, and bull trout; and (4) evaluate the effects of water diversions on water temperature for the selected streams.
Ultimately, the goal of these studies is to provide streamflow and fish habitat information to water-resource managers so informed decisions can be made to enhance instream habitat needs of ESA-listed fish species. A Web page maintained by the U.S. Geological Survey (USGS) that provides supporting data and modeling results can be accessed at http:/|id.water.usgs.gov/projects/salmon_streamflow|

\section{Previous Studies}

Previous instream flow studies conducted in the upper Salmon River Basin consist of investigations for the Snake River Adjudication (SRA) process, which were funded by the Bureau of Indian Affairs (BIA) and U.S. Forest Service (USFS). The BIA funded a number of fishery studies in the Salmon River Basin that focused on the development of instream flow recommendations for the preservation of important fishery resources. Between 1989 and 1992, the BIA contracted with EA Engineering, Science, and Technology to develop instream flow recommendations for important fishery resources and prepared suitability criteria, conducted instream flow studies, made recommendations, and filed water right claims as part of the SRA (EA Engineering Science and Technology Incorporated, 1989, 1991a, b, 1992a, b, c). The BIA also funded the USGS to classify Salmon River subbasins on the basis of basin and hydrologic characteristics to assist in the filing of water right claims (Lipscomb, 1998).

Investigations by the USFS also were conducted by Hardy and others (1992) to file water right claims for protection of fishery resources on public lands. More recent (199798) instream flow studies also were completed by the USFS on selected streams in the upper Salmon River Basin (M. Combs, Utah State University, oral commun., 2003). These data also were collected for the SRA to evaluate minimum and maintenance streamflows for the protection of important fishery resources; however, these data were never published.

A variety of methods have been developed to estimate streamflow needs for fish. Tennant (1976) offered one of the first methodologies for determining instream flows to protect aquatic resources. This simple approach recommends minimum stream discharges based on a percentage of mean annual discharge (MAD) that varies with the level of resource protection from poor to outstanding. Hatfield and Bruce (2000) developed equations for predicting optimum (maximum) discharge for selected salmonid life stages in western North America streams by using results from 127 PHABSIM studies. They concluded that MAD was the best predictor of optimum discharge. However, the 95-percent error estimates around the optimum predicted discharge can be substantial. The National Oceanic and Atmospheric Administration (NOAA) has draft protocols to estimate tributary streamflows to protect salmon listed under the ESA (D. Arthaud, National Oceanic and Atmospheric Administration, written commun., 2001). These protocols offer specific guidelines based on percentages of mean monthly streamflow and PHABSIM optimum estimates. 


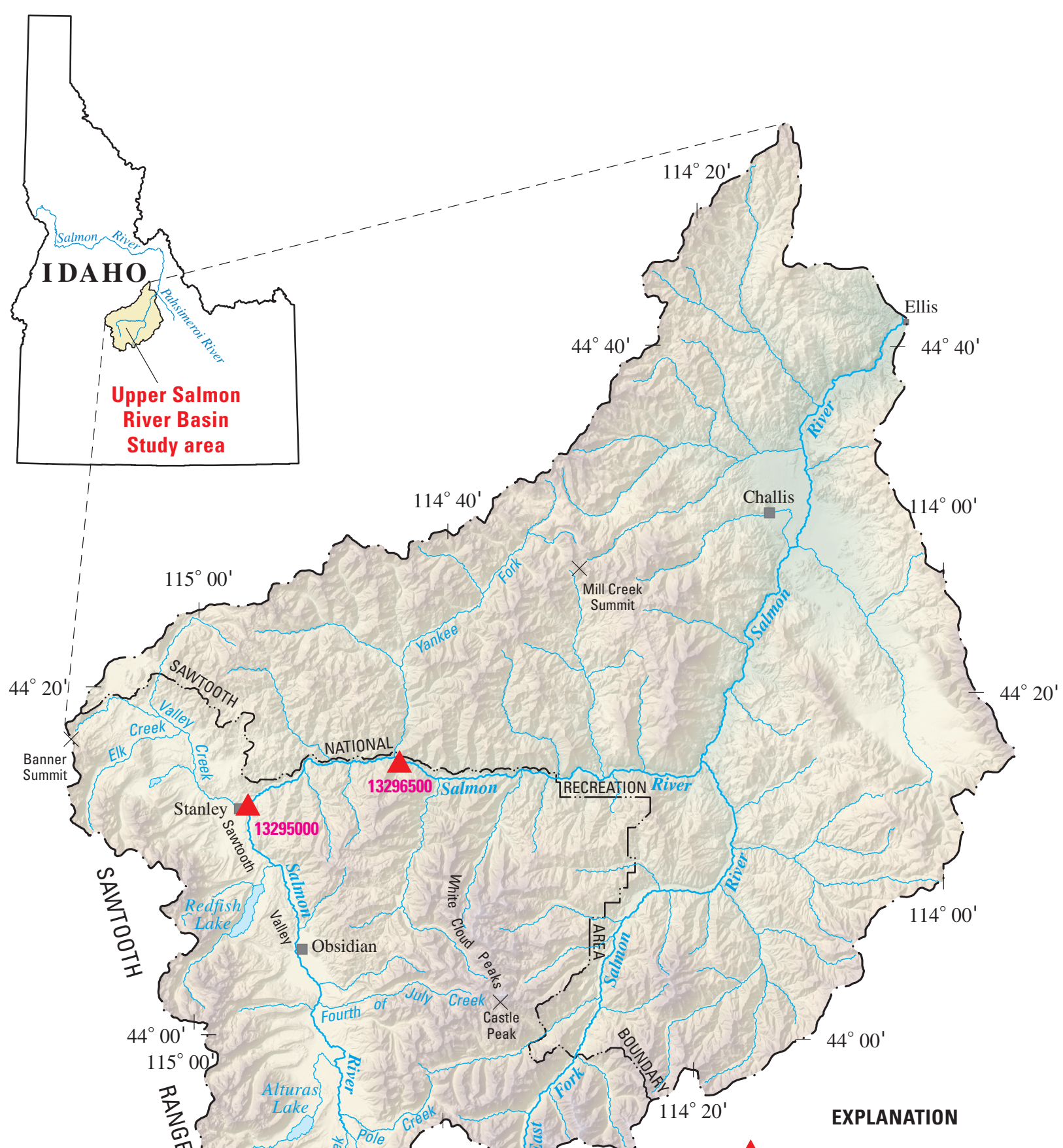

U.S. Geological Survey gaging station and identification

13296500 Salmon River below Yankee Fork 13295000 Valley Creek at Stanley

Base from U.S. Geological Survey digital data; 1998; 1:40,000,

Transverse Mercator projection; Factor at central meridian: 0.99960;

Longitude of central meridian: $-114^{\circ} 00^{\prime}$; Latitude of origin: $42^{\circ} 00^{\prime}$

False easting (meters): 500,000; False northing (meters): 100,000

Hydrography from U.S. Geological Survey; 1999; 1:24,000

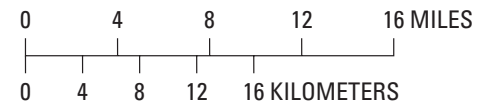

Figure 1. Location of upper Salmon River Basin, Idaho. 
Hydrologic studies by the USGS have provided information on streamflow statistics and geomorphology for streams in the Salmon River Basin. Hortness and Berenbrock (2001) developed regional regression equations that may be used to relate monthly and annual streamflow statistics to various basin characteristics (for example, basin area, basin elevation, percentage of forest cover in the basin, mean annual precipitation, and average basin slope). These equations are useful for predicting streamflow statistics in ungaged basins. Emmett (1975) evaluated hydrology, geomorphology, and water-quality characteristics of selected streams in the Salmon River Basin.

Habitat suitability curves for depth, velocity, and substrate are available for most native fish species of the Salmon River Basin. Rubin and others (1991) empirically determined suitability curves for juvenile chinook salmon and steelhead trout for small tributary streams in the Salmon River Basin. Cochnauer and Elms-Cockrum (1986) developed suitability curves for a number of Idaho salmonid species and their life stages by using guidelines provided by Bovee and Cochnauer (1977). EA Engineering Science and Technology Incorporated (1991b) developed a complete set of habitat suitability curves for depth, velocity, and substrate for most of the native fish species in the Salmon River Basin for the BIA as part of the SRA. These curves were developed following guidelines presented by Crance (1985) which consisted of a Delphi approach. This approach involves formal meetings among fishery experts to reach a consensus on suitability curves for various species and life stages.

Until recently, a significant study of stream temperature in the Salmon River Basin had not been undertaken. Starting in 2000, the USGS, in cooperation with the Idaho Department of Environmental Quality (IDEQ), initiated studies to document the natural spatial and temporal variability of stream temperature and to examine relations among stream temperature, environmental variables, and aquatic biota in streams minimally disturbed by human activities in the Salmon River Basin. Results showed that temperatures in these minimally disturbed streams commonly exceeded current State and Federal stream temperature standards.

During the summer of 2000, Donato (2002) studied the temperature regime of 183 minimally disturbed streams in the Salmon and Clearwater River Basins to develop a predictive stream temperature model. A major finding of this study was that temperatures in 100 percent (119 of 119) of the streams in the Salmon River Basin failed to meet the IDEQ $9.0^{\circ} \mathrm{C}$ maximum daily-average temperature (MDAT) and the $13.0^{\circ} \mathrm{C}$ maximum daily-maximum temperature (MDMT) criteria for the protection of salmonid spawning. Results also showed that stream temperatures in 33 percent (39 of 119) of the streams exceeded the IDEQ $19.0^{\circ} \mathrm{C}$ MDAT criterion, and temperatures in 39 percent ( 47 of 119 ) of the streams exceeded the $22.0^{\circ} \mathrm{C}$ MDMT criterion for the protection of coldwater biota.

In 2001, Ott and Maret (2003) studied 34 minimally disturbed streams in the Salmon River Basin to document the temperature regime, characterize the distribution of aquatic biota in streams representing a gradient of temperature, and describe the relations between environmental variables and benthic invertebrate and fish assemblages. Results of this study showed that the maximum weekly-maximum temperature (MWMT) in 100 percent (33 of 33) of the streams for which temperature data were available exceeded the U.S. Environmental Protection Agency (USEPA) criterion of $10^{\circ} \mathrm{C}$ for bull trout spawning and juvenile rearing. The MDMT in 91 percent ( 30 of 33) of the streams exceeded the IDEQ criterion of $13.0^{\circ} \mathrm{C}$ for the protection of salmonid spawning; and the MDAT in all 33 streams exceeded the $9.0^{\circ} \mathrm{C}$ criterion for the protection of salmonid spawning. Results also showed that stream temperatures in 9 percent ( 3 of 33) of the streams exceeded the IDEQ $19.0^{\circ} \mathrm{C}$ MDAT and the $22.0^{\circ} \mathrm{C}$ MDMT criteria for the protection of coldwater biota.

Even though temperatures in all streams exceeded at least one temperature criterion, Ott and Maret (2003) concluded that these same streams support populations of coldwater indicator species. They also concluded that a single stream temperature standard is difficult to apply across such a broad area as the entire State of Idaho because streams differ in environmental complexity and biological diversity.

\section{Description of Study Area}

The upper Salmon River Basin (figure 1) is located in central Idaho and extends $121 \mathrm{mi}$ from the headwaters on the east side of the Sawtooth Range to the confluence with the Pahsimeroi River near the town of Ellis, Idaho, draining an area of approximately $2,428 \mathrm{mi}^{2}$. The basin contains large areas that have been designated as wilderness, several national forests, and the SNRA. These features make the basin a popular destination for fishing, hiking, whitewater rafting, and other outdoor activities.

Elevation above sea level ranges from $11,815 \mathrm{ft}$ at Castle Peak to 4,640 ft at the confluence of the Salmon and Pahsimeroi Rivers. Mean elevation of the basin is 7,570 ft. Climate in most of the basin is semiarid and annual precipitation averages 24 in. per year. Precipitation is primarily snow, and peak flows in streams generally result from spring snowmelt.

The upper Salmon River Basin is located in the Idaho Batholith and Middle Rockies ecoregions (McGrath and others, 2001), which consist primarily of coniferous forests in upper elevations and sagebrush and grasslands in the valleys. Pine and fir predominate, covering 44 percent of the basin; rangeland covers the remaining 56 percent.

The geology of the basin consists primarily of metamorphic and sedimentary rocks, granite, volcanic rocks, and alluvium (King and Beikman, 1974). Much of the basin is characterized by stream channels deeply incised in bedrock and bordered by steep terrain.

Streams in the upper parts of watersheds in the basin typically have high water clarity, coarse-grained substrates (cobble and boulders), high stream gradients ( $>0.5$ percent), well- 
defined riffles and pools, and very sparse macrophyte growth. In contrast, streams in the lower part of the basin typically have lower water clarity, more fine-grained sediments, lower stream gradients, and generally denser macrophyte growth. These streams frequently are subjected to channelization, loss of riparian habitat by cattle grazing, and diversion of water for irrigation.

Designated aquatic life beneficial uses of the study streams include coldwater biota and salmonid spawning (Idaho Department of Environmental Quality, 2003). Limited waterquality sampling on small tributaries of the upper Salmon River Basin has indicated few signs of human activities (Ott and Maret, 2003). On the basis of IDEQ's total maximum daily load assessments, study streams were not water-quality limited and all beneficial uses were fully supporting (Idaho Department of Environmental Quality, 2003). In a few areas in the upper part of the basin, the effects of historical logging, mining, and cattle-grazing activities are noticeable.

According to SNRA biologists, the greatest impacts on anadromous fish and their habitat in the upper Salmon River Basin are the effects of water diversions and related instream flow problems (Scott and others, 1981). Of about 497 diversions in the basin, about 189 are within the SNRA boundary (M. Moulton, U.S. Forest Service, written commun., 2004). However, the actual amount of water diverted is unknown. The impacts of dewatering these streams include direct loss of valuable spawning and rearing habitats; blocking of access to historical spawning and rearing habitat; and disruption of the aquatic ecosystem brought about by annual recurrence of unnaturally low streamflows. Most diversions in the study area are screened to prevent loss of fish into irrigation diversions. Generally, water for irrigation in the basin is diverted from July through September and, because of the high elevation $(>7,000 \mathrm{ft})$, the resulting growing season is only about 80 days.

Invertebrates and fish in the Salmon River and its tributaries consist primarily of coldwater species. The most common benthic invertebrate orders are Ephemeroptera (mayflies), Plecoptera (stoneflies), Trichoptera (caddisflies), and Diptera (true flies); the most common fish families are Salmonidae (trout), Cottidae (sculpins), Cyprinidae (minnows), and Catostomidae (suckers). The most common fish species in the upper Salmon River Basin include bull trout, chinook salmon, resident rainbow (Oncorhynchus mykiss) and steelhead trout, brook trout (Salvelinus fontinalis), cutthroat trout (Oncorhynchus clarki), mountain whitefish (Prosopium williamsoni), longnose dace (Rhinichthys cataractae), and shorthead sculpin (Cottus confusus). Little historical information exists prior to irrigation on the use of upper Salmon River tributary streams by anadromous fish for spawning and rearing. According to IDFG, most tributary streams of the upper Salmon River offer coldwater refugia for juvenile salmonid rearing when the Salmon River water temperatures are not suitable (P. Murphy, Idaho Department of Fish and Game, oral commun., 2004). The endangered sockeye salmon once was found in five lakes within the upper Salmon River
Basin; however, it now returns only to Redfish Lake, where active recovery efforts are in operation (National Oceanic and Atmospheric Administration, 2002).

\section{Acknowledgments}

Numerous individuals assisted in collecting and processing data during the course of this study. Joseph Bunt, Ross Dickinson, Jack Doyle, Alvin Sablan, Kenneth Skinner, and Christopher Mebane, USGS, assisted with data collection. Jim Henriksen and Terry Waddle, USGS, provided training and technical guidance for PHABSIM modeling. Paul Devries of R2 Consultants provided useful background information on previous PHABSIM work they completed for the BIA. Matt Combs of Utah State University provided data sets from previous instream flow studies completed in the Salmon River Basin. Several individuals from the USFS also contributed to the study: Mark Moulton provided useful information about previous studies in the SNRA and gave valuable advice regarding stream characteristics and study design, Ruth Wooding assisted with obtaining landowner permission to access private land, and Tim Page provided information on previous studies conducted for the SRA process. Joe Spinazola, Ronald Sutton, and Al Simpson, Reclamation, contributed to planning and study design. A number of representatives of the Interagency Technical Workgroup organized by Reclamation also provided guidance: Cynthia Robertson and Thomas Curet (IDFG), Jim Morrow and Donald Anderson (NOAA), and Janna Brimmer (USFWS). Jacque Coles of the USGS provided assistance in building the Web site that accompanies this report. The authors wish to thank the colleague reviewers for improving the quality of this report. Funding for this study was provided by Reclamation and USGS.

\section{Data Collection Methods}

\section{Site Selection}

Once a list of priority streams based on input from the Interagency Technical Workgroup (see "Acknowledgments" for a list of members) was provided by Reclamation, the USGS conducted a reconnaissance on each stream to locate diversions and select potential study sites. Reclamation and USFS assisted in identifying private landowners and obtaining permission to access their land. PHABSIM study sites in the upper Salmon River Basin were selected following guidelines described by Bovee (1997). According to these guidelines, a geographical hierarchy is used to represent a study area in PHABSIM. The first-order subdivision of the study area is the stream segment. Stream segments are typically long sections of stream with a uniform flow regime and consistent geomorphology. Within the stream segment, there can be several habitat-related subdivisions, including representative reaches, mesohabitats, and microhabitats. 
The representative reaches and mesohabitat types describe the stream segment and make up the second-order division of the study area. A representative reach is approximately 10 to 15 channel widths in length and typically contains many or all of the mesohabitat types present in the entire segment. The proportions of the mesohabitat types in the reach also are assumed to be the same as their proportions in the segment. Mesohabitats are short sections of stream, usually with a length of about the same magnitude as the width, and have unique characteristics that distinguish them from other mesohabitat types. Mesohabitat types are identified through a process known as mesohabitat typing, which is an inventory of the proportions of each mesohabitat in a segment. Mesohabitat types commonly are delineated by localized slope, channel shape, and structure and generally are described as runs, riffles, or pools. Collectively, all the mesohabitat types represent the stream segment.

Typically, either the representative reach or mesohabitat typing is used to describe the stream segment. In this study, mesohabitat typing, using a cumulative-lengths approach, was used to describe the stream segment. In the cumulativelengths approach, the length of each mesohabitat type is measured during the inventory, and the proportion of a particular mesohabitat type in a segment is calculated as the cumulative length of all similar mesohabitat types divided by the total length of the segment that was surveyed.

Although a mesohabitat type often is described simply as a run, riffle, or pool, it can be stratified into finer subdivisions to describe the stream segment more accurately. Often, these finer subdivisions take into account varying degrees of slope, width, velocity, and depth. Eight mesohabitat categories were used in this study and represent backwater (pools) and varying degrees of slopes (riffles and runs) in both narrow and wide channels (figure 2). Specifically, these mesohabitats included shallow and deep pools representing backwater with a hydraulic control. Slopes were designated as low, moderate, or high on the basis of the amount of surface turbulence, velocity, and substrate size. Because of the large variation in stream types encountered, mesohabitat typing was based on relative changes within each stream. The overall goal of this approach was to categorize major habitat types present in each segment

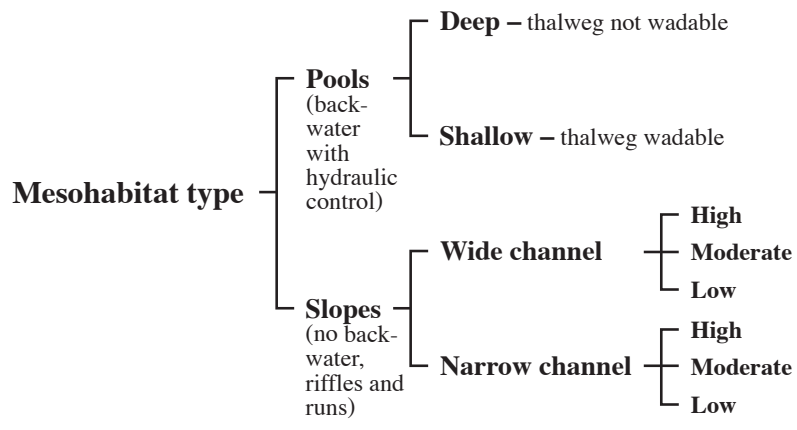

Figure 2. Hierarchical mesohabitat classification (Mesohabitats are equivalent to gemorphic channel units such as riffles, pools, and runs) and represent them in the PHABSIM modeling by weighting their relative importance.

PHABSIM study sites, the third-order division of a study area, describe either the representative reaches or the mesohabitat types. The study sites are divided longitudinally by stream cells and transects. When mesohabitat types are used to describe the stream segment, transects are established at the study site to represent the mesohabitat type and are weighted according to the proportion of the mesohabitat type in the segment. The segment is represented by all transects from all mesohabitat types. Generally, mesohabitats making up less than 10 percent of the stream segment were not included in the assessment.

Transects, the fourth-order division of a study area, are subdivided by lateral stream cells and verticals along which measures of microhabitat are made. Microhabitats are usually shorter than one channel width and represent a relatively homogeneous area utilized by an individual fish (Bovee, 1997). Examples of microhabitat include undercut banks, velocity shelters behind boulders, and woody debris.

Stream sites were established downstream from all diversions on each stream to evaluate the cumulative impact of multiple diversions. Additional study sites on the same stream were selected downstream from other upstream diversions if significant amounts of water ( $>10$ percent of the streamflow) were being diverted and (or) there were marked changes in stream geomorphology.

Shallow riffle habitats that potentially could create a bottleneck to passage were evaluated at each study site. One or more transects were placed across these areas at each study site to evaluate discharge relations and stream depth across the entire stream width.

\section{Environmental Variables}

\section{Physical Habitat}

Data were collected at verticals along transects to represent hydraulic and geomorphologic conditions in each cell in a mesohabitat type. Water-surface elevations were determined at each transect for at least two measured discharges. One additional stage-discharge pair was collected at some transects when cross-sectional data were collected at the verticals in the transect.

The data were collected at about 30 to 40 verticals to better define the habitat features of each transect. At each vertical in a transect, depth and mean velocity were measured, and cover and substrate types were determined. Cell width was determined from the spacing of the verticals. Channel structure and hydraulic variables were collected using standard USGS procedures described by Benson and Dalrymple (1967) and Rantz (1982). Transect and reference mark locations were georeferenced $( \pm 1 \mathrm{ft})$.

Hydrologic information for each study site was expressed using the Q.80, Q.50, and Q.20 exceedance discharge statis- 
tics. The exceedance discharge Qxx indicates the discharge (Q) that is equaled or exceeded xx percent for a specified time, such as annual or specific month.

Substrate types were identified by visual observation and were classified as silt, sand, gravel, cobble, or boulder. When more than one substrate type was observed at the vertical, such as gravel and cobble, the dominant substrate was determined.

Instream cover that provided velocity shelter and (or) protection from predators for fish was determined across each transect. Types of cover included woody debris, undercut banks, large substrate (for example, boulder or large cobble), aquatic vegetation, and overhanging vegetation (see Raleigh and others, 1986). To characterize stream shading, percent canopy opening was estimated at each transect with a clinometer following procedures described Fitzpatrick and others (1998).

\section{Stream Temperature}

Data loggers were used to record stream temperature throughout the study area. Data logger deployment and data collection followed procedures outlined by Stevens and others (1975) and Zaroban (2000). The digital data loggers used in this study (StowAway TidbiT; Onset Computer Corporation, Pocasset, Mass.) measure temperature to within $\pm 0.4^{\circ} \mathrm{C}$ and record temperature within a range of $-0.5^{\circ}$ to $37^{\circ} \mathrm{C}$. Prior to deployment of the data loggers, a calibration audit was conducted using an ice water and ambient temperature bath. Results of the audit showed that all data loggers recorded temperature to within $\pm 0.4^{\circ} \mathrm{C}$ of the audit temperatures as determined by a thermometer calibrated in accordance with American Society of Testing and Materials (ASTM) standards.

To capture the natural thermal regime and to assess the effects of diversions on stream temperature, the data loggers were deployed spatially throughout each stream. Generally, a data logger was placed far enough upstream from all diversions to avoid possible effects of diversions, at study site locations, and near the stream's mouth. Deployment consisted of selecting a well-mixed location in the stream, usually in the thalweg below a riffle, and attaching the data logger to a steel rod that was driven into the streambed. Data loggers were placed at mid-depth out of direct sunlight when possible and were programmed to record stream temperature hourly.

\section{Analytical Methods for Instream Flow Characterization}

\section{Physical Habitat Simulation Model}

Hydraulic and habitat simulation models contained in PHABSIM were used to characterize instream physical attributes (depth, velocity, substrate, and cover) over a range of expected summer (July through September) discharges.
A recently updated version of PHABSIM for Windows was used to analyze data for each study site (Waddle, 2001). To estimate the amount of fish habitat available over a range of discharges, hydrologic and habitat data were collected at a few targeted discharges representing the range of discharges for the period of interest at each study site. These data were used to calibrate a hydraulic model, which then was used to predict the stream hydraulic attributes (depth and velocity) over the range of discharges of interest. The biological importance of the stream hydraulic attributes then was assessed with the suitability criteria for each species and life stage to produce a relation between habitat availability and discharge. The final output was expressed as WUA for a representative stream segment. To facilitate interpretation, the WUA results were normalized to a percentage of maximum for the range of discharges simulated.

\section{Hydraulic Modeling and Calibration}

The hydraulics portion of the PHABSIM model includes calculation of water-surface elevations and velocity distributions. The following data collected in the field are required in this portion of the model: channel geometry, Manning's roughness (n) values, water-surface elevations, specific cell velocities, and stream discharges. Water-surface elevations can be calculated using one or any combination of the following methods: (1) stage-discharge relation or rating curve (STGQ), (2) Manning's equation (MANSQ), or (3) step-backwater water-surface profile (WSP) (Waddle, 2001). In most cases, the stage-discharge relation method is used only when three or more discharges and corresponding water-surface elevations are available. In both the stage-discharge relation and Manning's equation methods, the individual transects are independent of each other. In the WSP method, the individual transects are hydraulically connected.

The hydraulic portion of the PHABSIM model is calibrated in two separate steps. First, attempts are made to match the simulated water-surface elevations with the measured elevations. Calibration is performed by adjusting the n-values or related roughness variables within a realistic range as observed in the field until the simulated water-surface elevations match or nearly match the measured elevations. Typically, a difference of $0.02 \mathrm{ft}$ or less between the simulated and measured values is desirable (Waddle, 2001). Second, attempts are made to match the simulated velocities at each transect with the measured velocities for the measured discharges. This calibration is performed by adjusting local n-values in specific cells until the simulated velocities match or nearly match the measured velocities. A difference of $0.02 \mathrm{ft} / \mathrm{s}$ between the simulated and measured values is desirable (Waddle, 2001). It may be unrealistic to exactly simulate a measured velocity distribution. However, in relatively smooth, uniform channels, it may be possible to be close. On the contrary, velocity distributions for fairly rough, nonuniform channels are much more difficult to simulate, and the final calibration values are based on the user's selection of the simulation that best represents 
the measured values (J. Henriksen, Biological Resources Division, oral commun., 2004).

\section{Habitat Modeling}

\section{Selection of Target Species and Suitability Criteria}

Use of PHABSIM requires selection of target species, life stages present during the period of stream use (periodicity), and suitability criteria. This information was derived from previous SRA work by the BIA and USFS in the Salmon River Basin (EA Engineering Science and Technology Incorporated, 1991a, b). Upon review of this information, the Interagency Technical Workgroup directed the USGS to target the ESAlisted species bull trout, chinook salmon, and steelhead trout for juvenile, adult, and spawning life stages. The fry life stage ( $<50 \mathrm{~mm}$, or about $2 \mathrm{in}$.) was not modeled because of the inability to accurately measure microhabitat parameters at a scale that would be meaningful. The endangered sockeye salmon was not selected as a target species because its habitat in the upper Salmon River Basin generally is not directly affected by diversions. Because water is diverted for irrigation predominantly in summer (July through September), the Interagency Technical Workgroup recommended targeting this period for study. High streamflows for channel maintenance generally have not been as great an issue in the upper Salmon River Basin (M. Moulton, U.S. Forest Service, oral commun., 2003). ${ }^{1}$

Suitability criteria represent the quantification of the relative importance of depth, velocity, and channel index (substrate) for specific life stages of each species. Suitability index (SI) values for depth, velocity, and channel index range from 0 (no suitability) to 1.0 (maximum suitability). The Interagency Technical Workgroup recommended using suitability criteria previously developed for the SRA process (EA Engineering Science and Technology Incorporated, 1991a). The suitability curves selected for use in this study were developed within the Pacific Northwest and Idaho, making them applicable to upper Salmon River Basin streams. The suitability criteria and periodicity (period of stream use) for the various fish species and life stages targeted in this study can be accessed at http://

\section{id.water.usgs.gov/projects/salmon streamflow/habitat_curves}

The habitat program HABTAE within PHABSIM was used to estimate WUA for the simulated discharges of interest. A number of specific settings were used in this habitat simulation program. The geometric mean calculation was used to derive the composite index (CI) score for each cell. The CI was calculated as the geometric mean of the input variable:

$$
\mathrm{Cl}=\left(\mathrm{SI}_{1} \times \mathrm{SI}_{2} \times \ldots \times \mathrm{SI}_{\mathrm{n}}\right)^{1 / \mathrm{n}},
$$

where $\mathrm{SI}_{\mathrm{n}}$ is the suitability index value for variable $\mathrm{n}$, and $\mathrm{n}$ is the number of input variables. Calculating the $\mathrm{CI}$ on the basis of the geometric mean allows for more compensatory relations among variables than an arithmetic mean does (J. Henriksen,
Biological Resources Division, oral commun., 2003). For example, if two of three individual composite suitabilities are within the maximum range and the third is very low, the third individual composite suitability has a reduced effect on computation of the CI. The resulting CI value, combined with the surface area measured for various discharge scenarios, represents the weighted suitability, where a value of 1.0 indicates maximum habitat for the target species and life stage. The WUA is the sum of the products of CI values and surface area for all transect cells representing the study area.

Nose velocity settings were used for adult and juvenile bull trout as recommended by EA Engineering Science and Technology Incorporated (1991b). Specific settings for nose velocity consisted of estimates of Manning's n, which ranged from 0.04 to 0.06 for the study sites, depth of $0.2 \mathrm{ft}$ from the stream bottom, and use of a power law to calculate nose velocity from mean column velocity (Waddle, 2001). Default settings and mean column velocities were used to compute SI scores for all other species and life stages.

Because instream cover is important to juvenile salmonids for velocity shelters and protection from predators (Hillman and others, 1987; Spangler and Scarnecchia, 2001), and because all substrates are considered suitable for juvenile life stages, cover was substituted for substrate as a component of channel index in PHABSIM. Model results are reported separately for total WUA cover in relation to incremental changes in discharge for each site.

\section{Passage Criteria}

The passage criterion recommended by Thompson (1972) for stream depth over width was used to evaluate individual transects at each study site. For adult passage, the minimum depth criterion to be applied must be present over 25 percent of the total stream width and contiguous over at least 10 percent of the stream width at a representative transect. This criterion represents a minimum depth over relatively short stream distances, generally less than $20 \mathrm{ft}$ (Arthaud and others, 2001). The minimum depth criterion recommended by Thompson (1972) is $0.8 \mathrm{ft}$ for chinook salmon. According to SNRA biologists, this criterion is too high for marginally acceptable anadromous adult fish passage in the upper Salmon River Basin (Scott and others, 1981). Therefore, a depth criterion of $0.6 \mathrm{ft}$ (Scott and others, 1981) was used in this study to assess anadromous fish passage. Shallower water depths can allow passage. On August 15, 2002, adult chinook were observed in Valley Creek moving through a shallow riffle that was $0.2 \mathrm{ft}$ deep. Depths that would provide marginal adult chinook passage also would meet the requirements of passage for other adult and juvenile fish.

A hydraulic parameter option within PHABSIM called AVDEPTH/AVPERM was used to characterize the hydraulic properties of each passage transect (Waddle, 2001). Stream depth criteria between 0.4 and $0.8 \mathrm{ft}$ were used to evaluate the amount of stream width available for passage at the simulated discharges for each transect. Results are displayed graphically

\footnotetext{
${ }^{1}$ This sentence was revised January 13, 2005.
} 
to show the relation between discharge and the specified depth criteria over stream width.

\section{Stream Temperature}

Stream temperature data were inspected for obvious errors such as data logger malfunction and exposure to air temperatures. Data collected prior to deployment and after retrieval were removed from the data set. Time-series plots and other forms of graphical displays were used to inspect the data and to compare data sets. Temperature metrics, which characterize the thermal regime of stream temperatures, were calculated for all data sets and consisted of MDMT, MDAT, MWMT, and maximum-weekly (7-day) average temperature (MWAT). Maximum 7-day metrics were derived from the 7day moving average of daily (maximum or average) temperatures.

To ensure that stream temperatures stay within the optimal range, State and Federal regulatory agencies have established stream temperature standards. IDEQ is tasked with establishing and enforcing water-quality standards, which include stream temperature criteria. In the early 1990s, the IDEQ established stream temperature criteria of $22.0^{\circ} \mathrm{C}$ MDMT and $19.0^{\circ} \mathrm{C}$ MDAT for the protection of coldwater biota, and $13.0^{\circ} \mathrm{C}$ MDMT and $9.0^{\circ} \mathrm{C}$ MDAT for the protection of salmonid spawning (Grafe and others, 2002). In addition to the Idaho water-quality standard stream temperature criteria, the USEPA imposed a site-specific rule on those water bodies where bull trout are present (40 CFR 131.E.1.i.d, 1997). This rule set a criterion of $10.0^{\circ} \mathrm{C}$ MWMT during June through September for the protection of bull trout spawning and juvenile rearing in natal streams.

Although these stream temperature criteria have been established, it is recognized that a single stream temperature criterion for all streams may not accommodate the natural temperature variation within and among streams or the existence of naturally warm water. Consequently, temperatures in Idaho streams commonly exceed the criteria (Essig, 1998; Maret and others, 2001; Donato, 2002; Ott and Maret, 2003).

A Stream Segment Temperature (SSTEMP) model (Bartholow, 2002), developed to assist resource managers predict the consequences of stream and watershed manipulation on water temperatures, was explored for use in determining the effects of diversions on water temperature in streams in the upper Salmon River Basin. SSTEMP is a mechanistic, onedimensional, heat-transport model that predicts daily mean and maximum water temperatures as a function of stream distance and environmental heat flux. The model calculates net heat flux as the sum of heat to or from a stream by using longwave atmospheric radiation, direct short-wave solar radiation, convection, conduction, evaporation, shading, streambed fluid friction, and the water's back radiation. The model also incorporates ground-water influx. SSTEMP is based on the dynamic temperature steady-flow equation and assumes that all input data, including meteorological and hydrological variables, can be represented by daily averages. SSTEMP can be used to predict natural stream temperatures at a location that then can be compared with measured water temperatures affected by dewatering of the stream by diversions. Ultimately, this model can be used to identify streamflows required to minimize temperature effects on the targeted fish species.

\section{Guidelines for Using Study Results}

The results presented in this report summarize the hydrology, habitat, and temperature characteristics of each stream in the study area. PHABSIM, the primary analysis tool used, provides output of WUA in relation to discharge for target species and life stages. WUA is thought to be proportional to habitat availability (Bovee and others, 1998). This output can be illustrated with a series of graphs showing curves for each life stage for the fish species of interest. The highest point on each curve represents the discharge at which WUA is maximized for adult, spawning, or juvenile life stages. These maximum values rarely coincide among life stages for any one species or for several species. Furthermore, the habitat/discharge relation does not address water availability; even the unregulated flow may commonly be less than the discharge at which the maximum WUA is available. The amount of WUA lost or gained can be determined by comparison with a reference, or unregulated, streamflow condition. Typically, the maximum, percentiles, or inflections are chosen from these curves at the level of protection desired or at points above which greater amounts of flow provide only minor gains in usable habitat. In streams with more than one species of interest, it would be appropriate to review the results to ensure that the recommended flows are beneficial to all species and harmful to none.

Discharge/depth relations for adult fish passage were evaluated at each study site at selected transects across wide, shallow areas. These areas were identified during the stream mesohabitat typing phase of the assessment and represent potential passage barriers or "bottlenecks." If available, results from multiple passage transects can be averaged to best represent the overall passage conditions and streamflow needs for a particular stream segment. The relative percentage of mesohabitat types representing selected passage transects can be used to approximate the amount of potential passage habitat in various stream segments. This information may help identify those streams that have a relatively large amount of wide, shallow habitat that may restrict adult fish passage.

The mechanisms by which the various components are integrated and the relative importance they are assigned within the water-management decision process is a matter of professional judgment and beyond the scope of this study. Failure to provide adult fish passage connecting to the Salmon River would preclude success of improved conditions for spawning; therefore, ensuring enough water for adult fish passage would be foremost in management priorities. Water depth for adult 
passage is an additional consideration for the adult life stage. If possible, the choice of target flows should not reduce the water depth below that required for adult fish passage.

Discharge estimates providing maximum WUA for juvenile salmonid life stages are usually less than summer base flows, indicating a disconnect between the PHABSIM model results and actual juvenile salmonid needs. PHABSIM studies on streams in Washington demonstrated that streamflows estimated to produce maximum WUA for juvenile coho salmon (Oncorhynchus kisutch) were less than streamflows determined to actually increase juvenile recruitment $(\mathrm{H}$. Beecher, Washington Department of Fish and Wildlife, oral commun., 2004). When estimated flow for maximum juvenile WUA is less than estimated unimpaired summer base flow, the unimpaired summer base flow would be considered optimum until stream-reach-specific fish population and streamflow relations can be obtained (J. Morrow, National Oceanic and Atmospheric Administration, written commun., 2004).

Reasons for the apparent disparity between juvenile WUA curves and actual fish population and flow relations may include: inability to accurately measure and (or) quantify habitat parameters such as velocity, cover, and substrate at a scale that is meaningful for small fish; inability to accurately quantify side channels, bank indentations, riparian wetlands, or other lateral habitat that is important for rearing juvenile salmonids; inability to adequately incorporate temperature or other water-quality parameters into the model; and use of habitat suitability criteria that do not consider importance of high-velocity water in adjacent cells. Hampton (1988) determined that water velocity is the critical hydraulic parameter that determines microhabitat selection for juvenile chinook salmon and steelhead trout. For example, juvenile chinook salmon are strongly associated with pool habitat with little or no velocities (Hillman and others, 1987; Roper and others, 1994). However, stream salmonids have been observed to reside in, and forage from, microhabitat locations that were shielded from the current but adjacent to high-velocity water (Everest and Chapman, 1972). Likewise, foraging models that address improved foraging conditions associated with high-velocity flow near cover are correlated with growth and survival of juvenile Atlantic salmon (Salmo salar) (Nislow and others, 2004). Accurately modeling WUA for juvenile stream salmonids may require use of habitat suitability criteria developed using foraging models (Baker and Coon, 1997) and (or) more comprehensive modeling of habitat parameters.

To focus the integration of the various modeling results and relevant species and life stages, it is suggested that a priority species and life stage ranking approach be developed for each stream and period of concern. For example, the USFS prioritized federally listed anadromous species with the highest ranking, followed by Species of Special Concern, in their adjudication of water right claims for selected streams in central Idaho (Hardy, 1997). Prioritizing life stages present for the month or period of concern would benefit the selection of a target flow using the assumption that the priority life stage would require higher streamflows than other life stages would.
Generally, for small tributary streams of the upper Salmon River Basin, this priority ranking would be (from high to low): passage $>$ spawning $>$ adult $>$ juvenile. The ranking approach should involve discussions among resource-management agency representatives familiar with the streams of interest. Once the priority species and life stage are ranked, then each study site should be examined to determine streamflow and passage conditions for the period of interest. The results from PHABSIM provide a science-based linkage between biology and river hydraulics; however, there is no one single answer from this approach. PHABSIM results, along with other hydrologic and biological information, are intended to be used in negotiations or mediated settlements.

Habitat results are presented for each target species and life stage over an incremental range of discharges, allowing flexibility in interpretation. Because the streams studied are relatively small tributaries (basin size $<80 \mathrm{mi}$ ) to the Salmon River, a greater proportion of discharge is required to provide suitable water depths for fish habitat and connectivity for passage (Hatfield and Bruce, 2000). Once an adequate number of sites have been characterized using PHABSIM, it may be feasible to develop habitat/discharge relations for streams with similar basin characteristics within specific geographic locations. This could provide a regional planning tool that could eliminate intensive, site-specific studies.

The natural hydrograph also needs to be considered when developing flow targets. In drought years, summer flows that provide maximum possible habitat may not be attainable because of the hydrologic limits on the stream. Also, PHABSIM does not estimate flow or habitat needs of downstream juvenile migrants or spring runoff conditions necessary for maintenance of channel morphology or riparian zone functions. Arthaud and others (2001) have shown that downstream juvenile migrant survival can increase significantly with discharge. Thus, high spring flows that mimic the natural hydrograph can be a consideration in managing streamflows outside PHABSIM analysis.

\section{Climatic and Hydrologic Conditions During 2003}

Climatic and hydrologic conditions in the upper Salmon River Basin were near normal (30-year record, 1971-2000) during water year 2003 (WY03). Monthly snowpack levels were slightly below normal between January 1 and June 1, 2003. The average temperature during the 12 months of WY03 was slightly higher than the 30-year record average, whereas the average monthly temperatures were both above and below average. Annual mean streamflows in the basin were slightly below the long-term means, whereas monthly mean streamflows were both above and below the long-term means. 


\section{Climatic Conditions}

Average monthly snowpack levels for the Salmon River Basin upstream from Salmon, Idaho, ranged from 83 to 105 percent of normal during the period January 1 to June 1 . The average snowpack value for this area on April 1, 2003, was 96 percent of normal (Natural Resources Conservation Service, 2004b). The April 1 value is the most commonly used indicator of snowpack conditions since, in most years, it is the final value calculated before snowmelt begins. Observation sites located within or near the upper Salmon River Basin are Banner Summit (near the headwaters of Valley Creek), Galena Summit (at the headwaters of the Salmon River), Mill Creek Summit (at the headwaters of Yankee Fork), and Vienna Mine (at the headwaters of Smiley Creek). Specific snowpack levels at these sites on April 1, 2003, were as follows: Banner Summit, 93 percent of normal; Galena Summit, 96 percent of normal; Mill Creek Summit, 78 percent of normal; and Vienna Mine, 86 percent of normal (Natural Resources Conservation Service, 2004a).

The mean temperature at Stanley, Idaho, during WY03 was about $2.44^{\circ} \mathrm{C}\left(36.4^{\circ} \mathrm{F}\right)$, slightly higher than the 30 -year (1971-2000) mean of $1.83^{\circ} \mathrm{C}\left(35.3^{\circ} \mathrm{F}\right)$. Mean daily temperatures were slightly higher during June through September 2003 than during the long-term (1971-2000) record (figure 3). Mean monthly temperatures during the period when snowpack generally accumulates (October through April) were somewhat variable. Mean temperatures during October, November, and February were below the mean, whereas those during December, January, and March were above the mean. The mean April temperature was equal to the 30-year mean (Western Regional Climate Center, 2004).

\section{Hydrologic Conditions}

Annual mean streamflows at the long-term USGS gaging stations on Valley Creek at Stanley (13295000; 63 years of record) and on the Salmon River below Yankee Fork (13296500; 73 years of record) were approximately 7.5 and 9.7 percent below the long-term means, respectively. The annual mean streamflow at Valley Creek at Stanley was $185 \mathrm{ft}^{3} / \mathrm{s}$ compared with the long-term mean of $200 \mathrm{ft}^{3} / \mathrm{s}$, and the annual mean streamflow at the Salmon River below Yankee Fork was $883 \mathrm{ft} 3 \mathrm{~s}$ compared with the long-term mean of $978 \mathrm{ft} \%$ s. Monthly mean streamflows at Valley Creek at Stanley were generally slightly below the long-term means, with the exception of those for February, March, April, and June, which were slightly above the long-term means. Similarly, monthly mean streamflows at the Salmon River below

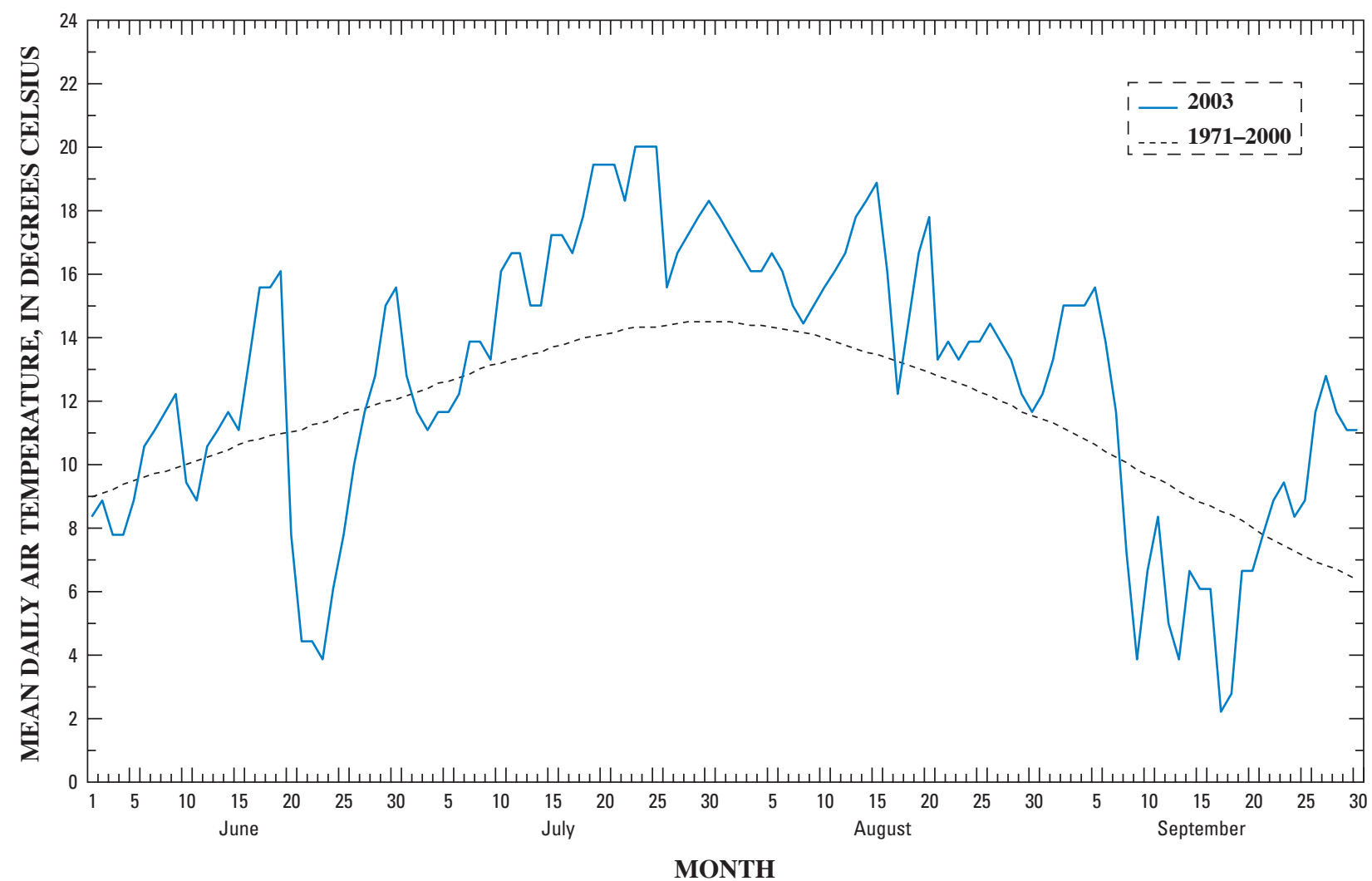

Figure 3. Mean daily air temperature for period June through September 2003 in relation to long-term (1971 through 2000) mean daily temperature measured at Stanley Ranger Station, upper Salmon River Basin, Idaho 
Table 1. Basin and site characteristics for gaging stations, diversions, and study sites in the upper Salmon River Basin, Idaho, 2003

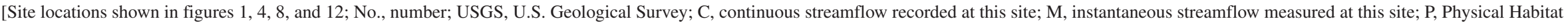
Simulation (PHABSIM) study site; T, continuous water temperature recorded at this site; latitude and longitude in degrees, minutes, and seconds; $\mathrm{mi}^{2}$, square miles; in., inches; —, no data]

\begin{tabular}{|c|c|c|c|c|c|c|c|c|c|c|}
\hline $\begin{array}{l}\text { Site } \\
\text { No. }\end{array}$ & Site name & $\begin{array}{l}\text { Site } \\
\text { type }\end{array}$ & Latitude & Longitude & $\begin{array}{l}\text { Basin } \\
\text { area } \\
\left(\mathrm{mi}^{2}\right)\end{array}$ & $\begin{array}{c}\text { Basin } \\
\text { slope } \\
\text { (percent) }\end{array}$ & $\begin{array}{c}\text { Mean } \\
\text { elevation } \\
\text { (feet } \\
\text { above } \\
\text { sea } \\
\text { level) }\end{array}$ & $\begin{array}{l}\text { Percent } \\
\text { forest }\end{array}$ & $\begin{array}{l}\text { Mean } \\
\text { annual } \\
\text { precipi- } \\
\text { tation } \\
\text { (in.) }\end{array}$ & $\begin{array}{l}\text { Stream segment } \\
\text { represented } \\
\text { by PHABSIM } \\
\text { study site }\end{array}$ \\
\hline PCG & Pole Creek at USGS gage & $\mathrm{C}, \mathrm{M}, \mathrm{T}$ & 435436 & 1144524 & 18.4 & 38 & 8487 & 74 & 30 & - \\
\hline PCD1 & Pole Creek diversion & $\mathrm{M}$ & 435435 & 1144526 & - & - & - & - & - & - \\
\hline PC2 & Upper Pole Creek & $\mathrm{M}, \mathrm{P}, \mathrm{T}$ & 435431 & 1144531 & 18.6 & 38 & 8477 & 74 & 30 & $\begin{array}{l}\text { Private property boundary upstream to } \\
\text { PCD } 1^{1}\end{array}$ \\
\hline JCG & Fourth of July Creek at USGS gage & $\mathrm{C}, \mathrm{M}, \mathrm{T}$ & 440226 & 1144520 & 15.8 & 40 & 8934 & 72 & 33 & - \\
\hline JCD3 & Upper Fourth of July Creek diversion & M & 440228 & 1144523 & - & - & - & - & - & - \\
\hline $\mathrm{JC} 3$ & Upper Fourth of July Creek & $\mathrm{M}, \mathrm{P}, \mathrm{T}$ & 440213 & 1144655 & 17.0 & 39 & 8862 & 71 & 33 & JCD2 upstream to JCD3 \\
\hline JCD2 & Middle Fourth of July Creek diversion & M & 440146 & 1144803 & - & - & - & - & - & - \\
\hline $\mathrm{JC} 2$ & Middle Fourth of July Creek & $\mathrm{M}, \mathrm{P}, \mathrm{T}$ & 440138 & 1144908 & 17.8 & 38 & 8763 & 68 & 32 & JCD1 upstream to JCD2 \\
\hline JCD1 & Lower Fourth of July Creek diversion & M & 440145 & 1144942 & - & - & - & - & - & - \\
\hline $\mathrm{JC} 1$ & Lower Fourth of July Creek & $\mathrm{M}, \mathrm{P}, \mathrm{T}$ & 440155 & 1145011 & 18.1 & 37 & 8731 & 67 & 31 & Mouth upstream to JCD1 \\
\hline ECG & Elk Creek at USGS gage & $\mathrm{C}, \mathrm{M}, \mathrm{T}$ & 441712 & 1150416 & 18.1 & 31 & 7559 & 65 & 27 & - \\
\hline ECD2 & Upper Elk Creek diversion & $\mathrm{M}$ & 441720 & 1150343 & - & - & - & - & - & - \\
\hline ECD1 & Lower Elk Creek diversion & M & 441726 & 1150142 & - & - & - & - & - & - \\
\hline $\mathrm{EC} 1$ & Lower Elk Creek & $\mathrm{M}, \mathrm{P}, \mathrm{T}$ & 441734 & 1150129 & 20.4 & 28 & 7471 & 67 & 26 & Mouth upstream to ECD1 \\
\hline VCGU & Valley Creek at upper USGS gage & $\mathrm{C}, \mathrm{M}, \mathrm{T}$ & 441857 & 1150401 & 29.4 & 30 & 7695 & 80 & 27 & - \\
\hline VCD4 & Upper Valley Creek diversion & M & 441837 & 1150321 & - & - & - & - & - & - \\
\hline $\mathrm{VC} 3$ & Upper Valley Creek & $\mathrm{M}, \mathrm{P}, \mathrm{T}$ & 441835 & 1150320 & 27 & 29 & 7681 & 79 & 27 & $\begin{array}{l}\text { Private property boundary downstream } \\
\text { to VCD3 }\end{array}$ \\
\hline $\mathrm{VCD} 3$ & Upper/middle Valley Creek diversion & M & 441729 & 1150107 & - & - & - & - & - & - \\
\hline $\mathrm{VC} 2$ & Middle Valley Creek & $\mathrm{M}, \mathrm{P}, \mathrm{T}$ & 441739 & 1150130 & 41.9 & 25 & 7490 & 77 & 26 & $\begin{array}{l}\text { Confluence with Elk Creek upstream to } \\
\text { public access bridge }\end{array}$ \\
\hline $\mathrm{VCD} 2$ & Middle Valley Creek diversion & M & 441724 & 1150056 & - & - & - & - & - & - \\
\hline VCD1 & Lower Valley Creek diversion & M & 441623 & 1150030 & - & 一 & - & - & - & 一 \\
\hline $\mathrm{VC} 1$ & Lower Valley Creek & $\mathrm{M}, \mathrm{P}, \mathrm{T}$ & 441601 & 1150023 & 76 & 25 & 7396 & 72 & 25 & $\begin{array}{l}\text { Public access bridge upstream to con- } \\
\text { fluence with Elk Creek }\end{array}$ \\
\hline VCGL & Valley Creek at lower USGS gage & $\mathrm{C}, \mathrm{M}, \mathrm{T}$ & 441321 & 1145549 & 148 & 26 & 7320 & 63 & 24 & - \\
\hline
\end{tabular}


Yankee Fork were slightly below the long-term means, with the exception of those for February, March, and June, which were slightly above the long-term means.

\section{Results of Study Site Investigations During 2003}

Investigations were performed on four separate tributaries to the Salmon River during the summer and fall of 2003. Data were collected at eight study sites (table 1): one site on upper Pole Creek (PC2), three sites on Fourth of July Creek (JC3, JC2, and JC1), one site on lower Elk Creek (EC1), and three sites on Valley Creek (VC3, VC2, and VC1). A plan view of each PHABSIM study site showing the locations of specific transects can be found in the appendices, figure $1 \mathrm{~A}$, figure $10 \mathrm{~A}$, figure $19 \mathrm{~A}$, figure $28 \mathrm{~A}$, figure $39 \mathrm{~A}$, figure $48 \mathrm{~A}$, figure 57A, and figure 66A.

In addition to the data collected at these study sites, continuous streamflow was recorded at four locations upstream from all diversions on Pole Creek (PCG), Fourth of July Creek (JCG), Elk Creek (ECG), and Valley Creek (VCGU). Longterm streamflow information, especially for basins smaller than 20 to $30 \mathrm{mi}^{2}$, in the upper Salmon River Basin is lacking. Additional streamflow data collected in these smaller basins not only would provide much needed information in these areas, but also could improve the accuracy of the regression equations used to estimate streamflows at ungaged sites.

Instream cover plays an important role in habitat selection for juveniles (Hampton, 1988). However, modeling fish cover presence for juvenile life stages proved to be problematic because of model limitations. Because all substrate types receive a suitability score of 1.0 for juvenile life stages, an attempt was made to substitute fish cover presence in the PHABSIM model by running this as a component of channel index. Because the composite suitability score equals zero when cover is absent in a cell, the resulting output produced WUA results only for cells with cover. Refinements of suitability criteria to score fish cover types by means of a discrete score rather than a binary score (that is, present or absent) may provide an opportunity to use cover more effectively in PHABSIM. Currently, this type of discrete scoring criteria for cover does not exist.

Juvenile instream cover WUA results were tabulated over the range of discharges modeled (see appendices, table 1A, table $3 \mathrm{~A}$, table $5 \mathrm{~A}$, table $7 \mathrm{~A}$, table $10 \mathrm{~A}$, table $12 \mathrm{~A}$, table $14 \mathrm{~A}$, and table 16A); however, final WUA graphs for each study site in the appendices do not include a cover component. Plots of cover WUA and discharge were evaluated for each study site, but these plots did not provide additional information that would enhance the determination of maximum habitat/discharge relations using PHABSIM (the maximum discharge range was essentially the same with and without the cover component). During their analysis of Snake River Adjudication data collected in Idaho, EA Engineering and Science Technology, Incorporated, also determined that PHABSIM was not effective in modeling instream cover ( $\mathrm{P}$. Devries, R2 Consultants, oral commun., 2003).

\section{Pole Creek (click here for study site investigation, figures $1 A-9 A$, and tables $1 A-2 A)$} Fourth of July Creek (click here for study site investigation,
figures $10 A-38 A$, and tables $3 A-9 A$ )

Elk Creek (click here for study site investigation, figures 39A-47A, and tables 10A-11A)

Valley Creek (click here for study site investigation, figures $48 \mathrm{~A}-74 \mathrm{~A}$ and tables $12 \mathrm{~A}-17 \mathrm{~A}$ )

\section{Summary}

Rivers, streams, and lakes in the upper Salmon River Basin historically provided migration corridors and significant habitat for anadromous chinook salmon, sockeye salmon, and steelhead trout. Wild salmon and steelhead in the basin migrate nearly 900 miles between the mountain streams and the Pacific Ocean. Resident bull trout also inhabit many of the rivers and streams in the basin. High-elevation spawning and rearing and extensive migrations may be very important for the long-term survival of these species.

Anadromous fish populations in the Columbia River Basin have plummeted in the last 100 years; this severe decline led to Federal listing of chinook salmon and steelhead stocks as endangered or threatened under the Endangered Species Act (ESA) in the 1990s. Human development has modified the original flow conditions in many streams in the upper Salmon River Basin. Summer streamflow modifications, as a result of irrigation practices, have directly affected the quantity and quality of fish habitat and also have affected migration and (or) access to suitable spawning and rearing habitat for these fish. Reduced streamflows resulting from diversions may contribute to increased water temperatures that may be unsuitable for native salmonids.

As a result of these ESA listings and Action 149 of the Federal Columbia River Power System Biological Opinion of 2000, the Bureau of Reclamation (Reclamation) was tasked to conduct streamflow characterization studies in the upper Salmon River Basin to clearly define habitat requirements for effective species management and habitat restoration. These studies were undertaken to evaluate potential fish habitat improvements by increasing streamflows as called for by the Federal Columbia River Power System Biological Opinion of 
2000. Results of these studies will be used to prioritize and direct cost-effective actions to improve fish habitat for ESAlisted anadromous and native fish species in the basin.

Numerous methods can be used to determine streamflow needs for fish and wildlife, but one of the most widely used is the Instream Flow Incremental Methodology, developed in the 1970s by physical and biological scientists in the U.S. Fish and Wildlife Service. A major component of Instream Flow Incremental Methodology is a collection of computer models called the Physical Habitat Simulation Model (PHABSIM). This model incorporates hydrology, stream morphology, and microhabitat preferences to create relations between streamflow and habitat availability. Habitat availability is measured by an index called the weighted usable area, which is the wetted area of a stream weighted by its suitability for use by an organism. PHABSIM simulates habitat/discharge relations for various species and life stages and allows quantitative habitat comparisons at different streamflows of interest.

Once a list of priority streams based on input from the Interagency Technical Workgroup was provided by Reclamation, the U.S. Geological Survey (USGS) conducted a reconnaissance on each stream to locate diversions and select potential study site locations. Mesohabitat typing, using a cumulative-lengths approach was used to describe the stream segment. In the cumulative-lengths approach, the length of each mesohabitat type is measured directly during the inventory, and the proportion of a particular mesohabitat type in a segment is calculated as the cumulative length of all like mesohabitat types divided by the total length of the segment that was surveyed. Because of the large variation in stream types encountered, mesohabitat typing was based on relative changes within each stream. Data were collected at verticals along transects to represent hydraulic and geomorphologic conditions in each cell in a mesohabitat type. At each vertical in a transect, depth and mean velocity were measured, and a cover and substrate type were determined.

Shallow riffle habitats that potentially could create a bottleneck to passage were evaluated at each study site. One or more transects were placed across these areas at each study site to evaluate discharge relations and stream depth across the entire stream width.

To capture the natural thermal regime and to assess the effects of diversions on stream temperature, data loggers were deployed spatially throughout each stream. Generally, a data logger was placed well upstream from all diversions, at study site locations, and near the stream's mouth.

Hydraulic and habitat simulation models contained in PHABSIM were used to characterize the instream physical attributes (depth, velocity, substrate, and cover) over a range of expected summer (July through September) discharges. The final output is expressed as weighted usable area (WUA) for a representative stream segment.

Climatic and hydrologic conditions in the upper Salmon River Basin were near normal during water year 2003 (WY03). Monthly snowpack levels were slightly below normal between January 1 and June 1, 2003. The average tem- perature during the 12 months of WY03 was slightly higher than the 30-year (1971-2000) average, whereas the average monthly temperatures were both above and below average. Annual mean streamflows in the basin were slightly below the long-term means, whereas monthly mean streamflows were both above and below the long-term means. Average monthly snowpack levels for the Salmon River Basin upstream from Salmon, Idaho, ranged from 83 to 105 percent of normal during the period January 1 to June 1.

The mean temperature at Stanley, Idaho, during WY03 was about $2.44^{\circ} \mathrm{C}$, slightly higher than the 30 -year (1971-2000) mean of $1.83^{\circ} \mathrm{C}$. Mean daily temperatures were slightly higher during June through September 2003 than during the long-term $(1971-2000)$ record.

Annual mean streamflows at the long-term USGS gaging stations on Valley Creek at Stanley (13295000; 63 years of record) and on the Salmon River below Yankee Fork (13296500; 73 years of record) were approximately 7.5 and 9.7 percent below the long-term means, respectively.

The results of PHABSIM provide a science-based linkage between biology and river hydraulics; however, there is no one single answer from this approach. Habitat results are presented for each target species and life stage over an incremental range of discharges, allowing flexibility in interpretation. Because the streams studied are relatively small tributaries (basin size $<80$ square miles) to the Salmon River, a greater proportion of discharge is required to provide suitable water depths for fish habitat and connectivity for passage.

Once an adequate number of sites have been characterized using PHABSIM, it may be feasible to develop habitat/ discharge relations for streams with similar basin characteristics within specific geographic locations. This could provide a regional planning tool that could eliminate intensive, site-specific studies.

Modeling fish cover presence for juvenile life stages proved to be problematic because of model limitations. Refinements of suitability criteria to score fish cover types by means of a discrete score rather than a binary score (that is, present or absent) may provide an opportunity to use cover more effectively in PHABSIM. Plots of cover, WUA, and discharge were evaluated for each study site, but these plots did not provide additional information that would enhance the determination of maximum habitat/discharge relations.

Caution is needed when interpreting juvenile WUA results because the streamflows necessary for maximum habitat for juvenile rearing may be underestimated using PHABSIM results. In fact, for streams that are being managed specifically for juvenile rearing, PHABSIM-derived WUA maximum discharges could be unrealistically low, resulting in flow regimes that are not protective of the fishery resource.

Investigations were performed on four separate tributaries to the Salmon River during the summer and fall of 2003. Data were collected at a total of eight study sites: one site on upper Pole Creek, three sites on Fourth of July Creek, one site on lower Elk Creek, and three sites on Valley Creek. 
Continuous streamflow was recorded at four locations upstream from all diversions on Pole Creek, Fourth of July Creek, Elk Creek, and Valley Creek. Long-term streamflow information, especially for basins smaller than 20 to 30 square miles, in the upper Salmon River Basin is lacking. Additional streamflow data collected in these smaller basins not only will provide much needed information in these areas, but also could improve the accuracy of the regression equations used to estimate streamflows at ungaged sites.

Analyses were completed to relate streamflows in Pole Creek during WY03 to long-term mean streamflows. Comparisons of July, August, and September monthly mean discharge during WY03 with long-term monthly mean discharge for the Valley Creek at Stanley gaging station (13295000) showed that WY03 monthly means were 25.3, 20.9, and 18.1 percent below the long-term monthly means, respectively.

Pole Creek is considered the highest quality fishery habitat within the Sawtooth National Recreation Area (SNRA) and has great potential to accommodate spawning of anadromous fish. However, this potential may be realized only if additional summer flows are provided to allow passage into spawning areas. Upper Pole Creek discharges required for maximum WUA ranged 7 to 17 cubic feet per second $\left(\mathrm{ft}^{3} / \mathrm{s}\right), 7$ to $29 \mathrm{ft}^{3} / \mathrm{s}$, and 9 to $29 \mathrm{ft}^{3} / \mathrm{s}$ for bull trout, chinook salmon, and steelhead trout life stages, respectively. Discharges required for passage over shallow riffle habitat ranged from 25 to $5 \mathrm{ft}^{3} / \mathrm{s}$ for the depth criterion of 0.6 foot over 25 percent of the total channel width and over 10 percent of the contiguous channel width, respectively.

Median discharge estimates for the months of July, August, and September for upper Pole Creek were 45.0, 17.3, and $13.7 \mathrm{ft}^{3} / \mathrm{s}$, respectively. The mean annual discharge estimate was $43.6 \mathrm{ft}^{3} / \mathrm{s}$.

Analysis of the stream temperature metrics for upper Pole Creek indicated a slight warming trend in a downstream direction. Results of the individual metric calculations showed that the maximum daily-maximum temperature (MDMT) was well below the MDMT of $21.0^{\circ} \mathrm{C}$ that can create a thermal barrier that would block adult chinook salmon from migrating to their spawning grounds. Also, the MDMT in upper Pole Creek never exceeded the $18.0^{\circ} \mathrm{C}$ threshold that may decrease bull trout migration.

Analyses were completed to relate streamflows in Fourth of July Creek during WY03 to long-term mean streamflows. The same techniques used to estimate long-term streamflows for Pole Creek also were used for Fourth of July Creek, Elk Creek, and Valley Creek study sites.

Upper Fourth of July Creek discharges required for maximum WUA ranged from 9 to $51 \mathrm{ft}^{3} / \mathrm{s}, 9$ to $39 \mathrm{ft}^{3} / \mathrm{s}$, and 9 to $39 \mathrm{ft}^{3} / \mathrm{s}$ for bull trout, chinook salmon, and steelhead trout life stages, respectively. Discharges required for passage over shallow riffle habitat were both $15 \mathrm{ft}^{3} / \mathrm{s}$ for the depth criterion of 0.6 foot over 25 percent of the total channel width and over 10 percent of the contiguous channel width.

Median discharge estimates for upper Fourth of July Creek for the months of July, August, and September were
$59.8,20.7$, and $15.3 \mathrm{ft}^{3} / \mathrm{s}$, respectively. The mean annual discharge estimate was $51.4 \mathrm{ft}^{3} / \mathrm{s}$.

Middle Fourth of July Creek discharges required for maximum WUA ranged from 12 to $18 \mathrm{ft}^{3} / \mathrm{s}, 9$ to $27 \mathrm{ft}^{3} / \mathrm{s}$, and 9 to $27 \mathrm{ft}^{3} / \mathrm{s}$ for bull trout, chinook salmon, and steelhead trout life stages, respectively. Discharges required for passage over shallow riffle habitat ranged from 11 to $9 \mathrm{ft}^{3} / \mathrm{s}$ for the depth criterion of 0.6 foot over 25 percent of the total channel width and over 10 percent of the contiguous channel width, respectively.

Median discharge estimates for middle Fourth of July Creek for the months of July, August, and September were $59.9,20.8$, and $15.6 \mathrm{ft}^{3} / \mathrm{s}$, respectively. The mean annual discharge estimate was $52.8 \mathrm{ft}^{3} / \mathrm{s}$.

Lower Fourth of July Creek discharges required for maximum WUA ranged from 12 to $18 \mathrm{ft}^{3} / \mathrm{s}, 7$ to $30 \mathrm{ft}^{3} / \mathrm{s}$, and 12 to $30 \mathrm{ft}^{3} / \mathrm{s}$ for bull trout, chinook salmon, and steelhead trout life stages, respectively. Discharges required for passage over two shallow riffle habitats near the mouth of the stream ranged from 18 to $5 \mathrm{ft}^{3} / \mathrm{s}$ and 27 to $12 \mathrm{ft}^{3} / \mathrm{s}$ for the depth criterion of 0.6 foot over 25 percent of the total channel width and over 10 percent of the contiguous channel width, respectively.

Median discharge estimates for lower Fourth of July Creek for the months of July, August, and September were 8, 20.2 , and $15.4 \mathrm{ft}^{3} / \mathrm{s}$, respectively. The mean annual discharge estimate was $51.9 \mathrm{ft}^{3} / \mathrm{s}$.

Analysis of the stream temperature metrics for Fourth of July Creek showed that temperatures were variable, but a gradual downstream warming trend was apparent. Large increases in water temperature in the lower end of Fourth of July Creek are not uncommon. In 2001, the U.S. Forest Service measured stream temperature increases of about $10^{\circ} \mathrm{C}$ between the U.S. Forest Service boundary and the mouth of Fourth of July Creek. The MDMT at all sites was below the $21.0^{\circ} \mathrm{C}$ threshold that can create a thermal barrier that would block adult chinook salmon from migrating to their spawning grounds. The MDMT exceeded $18.0^{\circ} \mathrm{C}$ in July and August at the lower site, indicating there may be decreased bull trout passage into Fourth of July Creek from the Salmon River as a result of high temperatures.

Lower Elk Creek discharges required for maximum WUA ranged from 34 to $59 \mathrm{ft}^{3} / \mathrm{s}, 18$ to $62 \mathrm{ft}^{3} / \mathrm{s}$, and 18 to $62 \mathrm{ft}^{3} / \mathrm{s}$ for bull trout, chinook salmon, and steelhead trout life stages, respectively. Discharges required for passage over shallow riffle habitat ranged from 34 to $12 \mathrm{ft}^{3} / \mathrm{s}$ for the depth criterion of 0.6 foot over 25 percent of the total channel width and over 10 percent of the contiguous channel width, respectively. Maximum WUA estimates determined by Utah State University at this same study site in 1999 were compared with maximum WUA estimates in this study. The University's WUA estimates ranged from 13 to $36 \mathrm{ft}^{3} / \mathrm{s}, 13$ to $64 \mathrm{ft}^{3} / \mathrm{s}$, and 18 to $64 \mathrm{ft}^{3} / \mathrm{s}$ for bull trout, chinook salmon, and steelhead trout, respectively, for the same three life stages. These maximum WUA estimates for bull trout were much lower than estimates in this study, whereas WUA estimates from both studies for chinook salmon and steelhead trout were similar. 
Median discharge estimates for lower Elk Creek for the months of July, August, and September were 34.3, 14.1, and $12.4 \mathrm{ft}^{3} / \mathrm{s}$, respectively. The mean annual discharge estimate was $39.2 \mathrm{ft}^{3} / \mathrm{s}$.

The MDMT measured on Elk Creek was below the $21.0^{\circ} \mathrm{C}$ threshold that can create a thermal barrier that would block adult chinook salmon from migrating to their spawning grounds. The MDMT exceeded $18.0^{\circ} \mathrm{C}$ in July and August at Elk Creek sites, indicating there may be decreased bull trout habitat and passage in Elk Creek as a result of high temperatures.

Valley Creek is one of the SNRA's most heavily utilized spawning streams for chinook salmon and steelhead trout. Upper Valley Creek discharges required for maximum WUA ranged from 13 to $29 \mathrm{ft}^{3} / \mathrm{s}, 9$ to $40 \mathrm{ft}^{3} / \mathrm{s}$, and 15 to $37 \mathrm{ft}^{3} / \mathrm{s}$ for bull trout, chinook salmon, and steelhead trout life stages, respectively. Discharges required for passage over shallow riffle habitat ranged from 15 to $8 \mathrm{ft}^{3} / \mathrm{s}$ for the depth criterion of 0.6 foot over 25 percent of the total channel width and over 10 percent of the contiguous channel width, respectively.

Median discharge estimates for upper Valley Creek for the months of July, August, and September were 19.0, 11.5, and $11.2 \mathrm{ft}^{3} / \mathrm{s}$, respectively. The mean annual discharge estimate was $29.7 \mathrm{ft}^{3} / \mathrm{s}$.

Middle Valley Creek discharges required for maximum WUA ranged from 36 to $84 \mathrm{ft}^{3} / \mathrm{s}, 24$ to $84 \mathrm{ft}^{3} / \mathrm{s}$, and 36 to 84 $\mathrm{ft}^{3} / \mathrm{s}$ for bull trout, chinook salmon, and steelhead trout life stages, respectively. Discharges required for passage over shallow riffle habitat were both $15 \mathrm{ft}^{3} / \mathrm{s}$ for the depth criterion of 0.6 foot over 25 percent of the total channel width and over 10 percent of the contiguous channel width. Maximum WUA estimates determined by Utah State University at this same study site in 1999 were compared with maximum WUA estimates in this study. The University's WUA ranged from 9 to $44 \mathrm{ft}^{3} / \mathrm{s}, 11$ to $70 \mathrm{ft}^{3} / \mathrm{s}$, and 21 to $70 \mathrm{ft}^{3} / \mathrm{s}$ for bull trout, chinook salmon, and steelhead trout, respectively, for the same three life stages. Generally, these maximum WUA estimates were lower than those in this study.

Median discharge estimates for middle Valley Creek for the months of July, August, and September were 32.9, 17.9, and $17.9 \mathrm{ft}^{3} / \mathrm{s}$, respectively. The mean annual discharge estimate was $48.2 \mathrm{ft}^{3} / \mathrm{s}$.

Lower Valley Creek discharges required for maximum WUA ranged from 23 to $75 \mathrm{ft}^{3} / \mathrm{s}, 20$ to $69 \mathrm{ft}^{3} / \mathrm{s}$, and 23 to 69 $\mathrm{ft}^{3} / \mathrm{s}$ for bull trout, chinook salmon, and steelhead trout life stages, respectively. Discharges required for passage over shallow riffle habitat ranged from 50 to $16 \mathrm{ft}^{3} / \mathrm{s}$ for the depth criterion of 0.6 foot over 25 percent of the total channel width and over 10 percent of the contiguous channel width.

Median discharge estimates for lower Valley Creek for the months of July, August, and September were 60.6, 31.5, and $31.0 \mathrm{ft}^{3} / \mathrm{s}$, respectively. The mean annual discharge estimate was $84.9 \mathrm{ft}^{3} / \mathrm{s}$.

Lower Valley Creek was the only study site where side channel habitat made up a significant portion ( $>10$ percent) of the stream segment assessed. Analysis of the inlet and outlet portions of the side channel revealed that a discharge of approximately $150 \mathrm{ft}^{3} / \mathrm{s}$ would be required to allow for a minimum passage depth of 0.4 foot for adult chinook. Because it is highly unlikely that natural discharges at this site during the months of July, August, and September would exceed 150 $\mathrm{ft}^{3} / \mathrm{s}$, this side channel likely does not contain suitable fish habitat during those months. In addition, no fish were observed during the initial site visit in July.

Analysis of the stream temperature metrics for Valley Creek indicated that, most of the time, there was a gradual warming trend downstream from upper to lower study sites. The MDMT at all sites was below the $21.0^{\circ} \mathrm{C}$ threshold that can create a thermal barrier that would block adult chinook salmon from migrating to their spawning grounds. The MDMT exceeded $18.0^{\circ} \mathrm{C}$ in July and August at all Valley Creek sites, indicating that there may be limited bull trout habitat and passage as a result of high water temperature.

\section{References Cited}

Arthaud, D., Kratz, K., Vandemoer, K., and Grady, M., 2001, Protocol for estimating tributary streamflow to protect salmon listed under the Endangered Species Act - Draft: National Marine Fisheries Service, Habitat Conservation Division, Northwest Region, 24 p.

Baker, E.A., and Coon, T.G., 1997, Development and evaluation of alternative habitat suitability criteria for brook trout: Transactions of the American Fisheries Society, v. 126, p. $65-76$.

Bartholow, J.M., 2002, Stream segment temperature model (SSTEMP) version 2.0: Fort Collins, Colo., U.S. Geological Survey, 29 p.

Beitinger, T.L., Bennett, W.A., and McCauley, R.W., 2000, Temperature tolerances of North American freshwater fishes exposed to dynamic changes in temperature: Environmental Biology of Fishes, v. 58, p. 237-275.

Benson, M.A., and Dalrymple, T., 1967, General field and office procedures for indirect discharge measurements: U.S. Geological Survey Techniques of Water-Resources Investigations, Book 3, Chap. A1, 30 p.

Berenbrock, C., 2003, Two-station comparison of peak flows to improve flood-frequency estimates for seven streamflowgaging stations in the Salmon and Clearwater River Basins, central Idaho: U.S. Geological Survey Water-Resources Investigations Report 03-4001, 27 p.

Bovee, K.D., 1997, Data collection procedures for the Physical Habitat Simulation System: Fort Collins, Colo., U.S. Geological Survey, Biological Resources Division, 141 p. 
Bovee, K.D., and Cochnauer, T., 1977, Development and evaluation of weighted criteria, probability of use curves for instream flow assessments - fisheries: U.S. Fish and Wildlife Service FWS/OBS-77/63, 39 p.

Bovee, K.D., Lamb, B.L., Bartholow, J.M., Stalnaker, C.B., Taylor, J., and Henriksen, J., 1998, Stream habitat analysis using the instream flow incremental methodology: U.S. Geological Survey Biological Resources Division Information and Technology Report USGS/BRD/ ITR - 1998-0004, $130 \mathrm{p}$.

Chapman, D.W., 1986, Salmon and steelhead abundance in the Columbia River in the nineteenth century: Transactions of the American Fisheries Society, v. 115, p. 662-670.

Cochnauer, T., and Elms-Cockrum, T., 1986, Subproject II. Regional coordination and assistance job \#1-a. Probability of use curves for selected Idaho fish species: Idaho Department of Fish and Game, 49 p.

Coutant, C.C., 1976, Thermal effects on fish ecology, in Encyclopedia of Environmental Science and Engineering: New York, Gordon and Breach, v. 2, p. 891-896.

Crance, J.H., 1985, Delphi technique procedures used to develop habitat suitability index models and instream flow suitability curves for inland stocks of striped bass: Fort Collins, Colo., U.S. Fish and Wildlife Service, WELUT-85/ W07, $58 \mathrm{p}$.

Donato, M.M., 2002, A statistical model for estimating stream temperatures in the Salmon and Clearwater River Basins, central Idaho: U.S. Geological Survey Water-Resources Investigations Report 02-4195, $39 \mathrm{p}$.

EA Engineering, Science, and Technology, Inc., 1989, Idaho instream flow studies, task 5 report - model evaluation and selection: Redmond, Wash., Prepared for Bureau of Indian Affairs, variously paged.

EA Engineering, Science, and Technology, Inc., 1991a, Review, evaluation and selection of final habitat suitability curves - Idaho instream flow project: Redmond, Wash., prepared for Bureau of Indian Affairs, variously paged.

EA Engineering, Science, and Technology, Inc., 1991b, Fish species periodicity within the Clearwater and Salmon River Basins, Idaho, Idaho instream flow studies: Redmond, Wash., Prepared for Bureau of Indian Affairs, variously paged.

EA Engineering, Science, and Technology, Inc., 1992a, Development and evaluation of flow recommendation procedures for use on the Idaho instream flow study: Redmond, Wash., Prepared for Bureau of Indian Affairs, $22 \mathrm{p}$.
EA Engineering, Science, and Technology, Inc., 1992b, Fish species distributions within the Salmon, Clearwater, Middle Snake, Weiser and North Fork Payette drainages of Idaho: Redmond, Wash., Prepared for Bureau of Indian Affairs, variously paged.

EA Engineering, Science, and Technology, Inc., 1992c, Stream flow and its relationship to the freshwater migrations of anadromous salmonids: Redmond, Wash., Prepared for Bureau of Indian Affairs, variously paged.

Emmett, W.W., 1975, The channels and waters of the upper Salmon River area, Idaho: U.S. Geological Survey Professional Paper 870-A, 116 p.

Essig, D.A., 1998, The dilemma of applying uniform temperature criteria in a diverse environment - an issue analysis: Boise, Idaho Division of Environmental Quality, 29 p.

Everest, F.H., and Chapman, D.W., 1972, Habitat selection and spatial interaction by juvenile chinook salmon and steelhead trout in two Idaho streams: Journal of the Fisheries Research Board of Canada, v. 29, p. 91-100.

Ezekial, M., and Fox, K.A., 1959, Methods of correlation and regression analysis: New York, John Wiley and Sons, 548 p.

Fitzpatrick, F.A., Waite, I.R., D’Arconte, P.J., Meador, M.E., Maupin, M.A., and Gurtz, M.E., 1998, Revised methods for characterizing stream habitat in the National Water-Quality Assessment Program: U.S. Geological Survey WaterResources Investigations Report 98-4052, 67 p.

Grafe, C.S., Mebane, C.A., McIntyre, M.J., Essig, D.A., Brandt, D.H., and Mosier, D.T., 2002, The Idaho Department of Environmental Quality water body assessment guidance, $2 \mathrm{~d}$ ed.: Idaho Department of Environmental Quality, $230 \mathrm{p}$.

Hampton, M., 1988, Development of habitat preference criteria for anadromous salmonids of the Trinity River: Sacramento, Calif., U.S. Fish and Wildlife Service, Division of Ecological Services, 93 p.

Hardy, T.B., 1997, Methodologies for quantification of multiple-use sustained-yield act claims: U.S. Forest Service, Boise Adjudication Team, Expert Witness Report, District Court of the Fifth Judicial District of the State of Idaho, in and for the County of Twin Falls, Case No. 39576, variously paged.

Hardy, T.B., Bart, B., and Carter, W., 1992, Region 1 and Region 4 hydraulic and habitat modeling, channel maintenance modeling data base and analysis system: Ogden, Utah, U.S. Forest Service, 114 p.

Hatfield, T., and Bruce, J., 2000, Predicting salmonid habitatflow relationships for streams from Western North America: North American Journal of Fisheries Management, v. 20, p. $1005-1015$. 
Hillman, T.W., Griffith, J.S., and Plats, W.S., 1987, Summer and winter habitat selection by juvenile chinook salmon in a highly sedimented Idaho stream: Transactions of the American Fisheries Society, v. 116, p. 185-195.

Hortness, J.E., and Berenbrock, C., 2001, Estimating monthly and annual streamflow statistics at ungaged sites in Idaho: U.S. Geological Survey Water-Resources Investigations Report 01-4093, 36 p.

Idaho Department of Environmental Quality, 2003, Upper Salmon River subbasin assessment and TMDL: Boise, Idaho Department of Environmental Quality, 216 p.

Instream Flow Council, 2002, Instream flows for riverine resource stewardship: Chap. 7, Instream Flow Assessment Tools, p. 171-304.

King, P.B., and Beikman, H.M., 1974, Geologic map of the United States: U.S. Geological Survey, scale 1:2,500,000.

Lipscomb, S.W., 1998, Hydrologic classification and estimation of basin and hydrologic characteristics of subbasins in central Idaho: U.S. Geological Survey Professional Paper $1604,49 \mathrm{p}$.

Maret, T.R., MacCoy, D.E., Skinner, K.D., Moore, S.E., and O'Dell, I., 2001, Evaluation of macroinvertebrate assemblages in Idaho rivers using multimetric and multivariate techniques, 1996-1998: U.S. Geological Survey WaterResources Investigations Report 01-4145, 69 p.

McCullough, D.A., Spalding, S., Sturdevant, D., and Hicks, M., 2001, Summary of technical literature examining the physiological effects of temperature on salmonids, issue paper 5: U.S. Environmental Protection Agency, EPA-910-D-01-005, $114 \mathrm{p}$.

McGrath, C.L., Woods, A.J., Omernik, J.M., Bryce, S.A., Edmondson, M., Nesser, J.A., Shelden, J., Crawford, R.C., Comstock, J.A., and Plocher, M.D., 2001, Ecoregions of Idaho (color poster with map, descriptive text, summary tables, and photographs): Reston, Va., U.S. Geological Survey (map scale 1:1,350,000).

Munther, G., 1974, Fishery effects of irrigation diversion and related structures in the Sawtooth National Recreation Area - progress report 1: U.S. Forest Service, 68 p.

National Oceanic and Atmospheric Administration, 2000, Endangered Species Act — Section 7 Consultation, Biological Opinion, Reinitiation of consultation on operation of the Federal Columbia River Power System, including the Juvenile Fish Transportation Program, and 19 Bureau of Reclamation projects in the Columbia Basin: accessed January 12, 2004, at URL http://www.nwr.noaa.gov/1 hydrop/ hydroweb/docs/Final/2000Biop.html
National Oceanic and Atmospheric Administration, 2002, Protected resources, sockeye salmon (Oncorhynchus nerka): accessed March 19, 2004, at URL http://www.nwr.noaa. gov/1salmon/salmesa/socksnk.htm

Natural Resources Conservation Service, 2004a, National Water and Climate Center, snowpack reports, water year 2003: accessed January 2004, at URL http:/|www.wcc.nrcs. usda.gov/snowcourse/snow_rpt.html

Natural Resources Conservation Service, 2004b, State basin outlook reports, water year 2003: accessed January 2004, at URL http://www.wcc.nrcs.usda.gov/cgibin/bor.pl

Nehlsen, W., Williams, J.E., and Lichatowich, J.A., 1991, Pacific salmon at the crossroads: stocks at risk from California, Oregon, Idaho, and Washington: Fisheries, v. 16, no. 2 , p. $4-21$.

Nislow, K.H., Sepulveda, A.J., and Folt, C.L., 2004, Mechanistic linkage of hydrologic regime to summer growth of age-0 Atlantic salmon: Transactions of the American Fisheries Society, v. 133 , p. $79-88$.

Ott, D.S., and Maret, T.R., 2003, Aquatic assemblages and their relation to temperature variables of least-disturbed streams in the Salmon River Basin, central Idaho, 2001: U.S. Geological Survey Water-Resources Investigations Report 03-4076, 45 p.

Poole, G., Dunham, J., Hicks, M., Keenan, D., Lockwood, J., Materna, E., McCullough, D., Mebane, C., Risley, J., Sauter, S., Spalding, S., and Sturdevant, D., 2001, Scientific issues relating to temperature criteria for salmon, trout, and char native to the Pacific Northwest: Technical Synthesis of the Water Temperature Criteria Technical Workgroup, U.S. Environmental Protection Agency, Region 10, 21 p.

Raleigh, R.F., Miller, W.J., and Nelson, P.C., 1986, Habitat suitability index model and instream flow suitability curves - chinook salmon: U.S. Fish and Wildlife Service Biological Report 82 (10.122), 64 p.

Rantz, S.E., 1982, Measurement and computation of streamflow - Volume 1. Measurement of stage and discharge: U.S. Geological Survey Water-Supply Paper 2175, 284 p.

Roper, B.B., Scarnecchia, D.L., and LaMarr, T.J., 1994, Summer distribution of and habitat use by chinook salmon and steelhead within a major basin of the south Umpqua River, Oregon: Transactions of the American Fisheries Society, v. 123, p. $298-308$.

Rubin, S.P., Bjornn, T.C., and Dennis, B., 1991, Habitat suitability curves for juvenile chinook salmon and steelhead developed using a habitat-oriented sampling approach: Rivers, v. 2, no. 1, p. 12-29. 
Sauter, S.T., McMillan, J., and Dunham, J., 2001, Salmonid behavior and water temperature, issue paper 1: U.S. Environmental Protection Agency, EPA-910-D-01-001, 36 p.

Scott, M., Contreras, G., Forsgren, H., Reynoldson, K., and McDevitt, G., 1981, Anadromous fish instream flow needs and conflicts within the Sawtooth National Recreation Area: U.S. Forest Service, 46 p.

Selong, J.H., McMahon, T.E., Zale, A.V., and Barrows, F.T., 2001, Effect of temperature on growth and survival of bull trout, with application of an improved method for determining thermal tolerance in fishes: Transactions of the American Fisheries Society, v. 130, p. 1026-1037.

Spangler, R.E., and Scarnecchia, D.L., 2001, Summer and fall microhabitat utilization of juvenile bull trout and cutthroat trout in a wilderness stream, Idaho: Hydrobiologia, v. 452, p. $145-154$.

Spinazola, J.M., 2002, Upper Salmon River Basin flow characterization studies: Boise, Idaho, Bureau of Reclamation, $4 \mathrm{p}$.

Stevens, H.H., Jr., Ficke, J.F., and Smoot, G.F., 1975, Water temperature - influential factors, field measurement, and data presentation: U.S. Geological Survey Techniques of Water-Resources Investigations, Book 1, Chap. D1, 65 p.

Tennant, D.L., 1976, Instream flow regimens for fish, wildlife, recreation, and related environmental resources, in Osborne, J., and Allman, C., eds., Instream flow needs, volume 2: Bethesda, Md., American Fisheries Society, Western Division, p. 359-373.
Thompson, K.E., 1972, Determining stream flows for fish life, Proceedings of the Instream Flow Requirement Workshop, March 15-16, 1972, Portland, Oreg.: Pacific Northwest River Basins Commission, p. 31-50.

Thurow, R.F., 2000, Dynamics of chinook salmon populations within Idaho's Frank Church Wilderness - implications for persistence: U.S. Forest Service Proceedings RMRS-P-15-VOL-3, p. 143-151.

Thurow, R.F., Lee, D.C., and Rieman, B.E., 2000, Status and distribution of chinook salmon and steelhead in the Interior Columbia River Basin and portions of the Klamath River Basin, in Knudsen, E.E., Steward, C.R., MacDonald, D.D., Williams, J.E., and Reiser, D.W., eds., Sustainable fisheries management — Pacific salmon: Boca Raton, Fla., Lewis Publishers, p. 133-160.

Waddle, T.J., 2001, PHABSIM for Windows-user's manual and exercises: Fort Collins, Colo., Midcontinent Ecological Science Center, U.S. Geological Survey Open-File Report $01-340,288$ p.

Western Regional Climate Center, 2004, Desert Research Institute, Idaho climate summaries: accessed January 2004, at URL http://www.wrcc.dri.edu/summary/climsmid.html

Zaroban, D.W., 2000, Protocol for placement and retrieval of temperature data loggers in Idaho streams: Idaho Department of Environmental Quality, Water Quality Monitoring Protocols, Report no. 10, 34 p. 


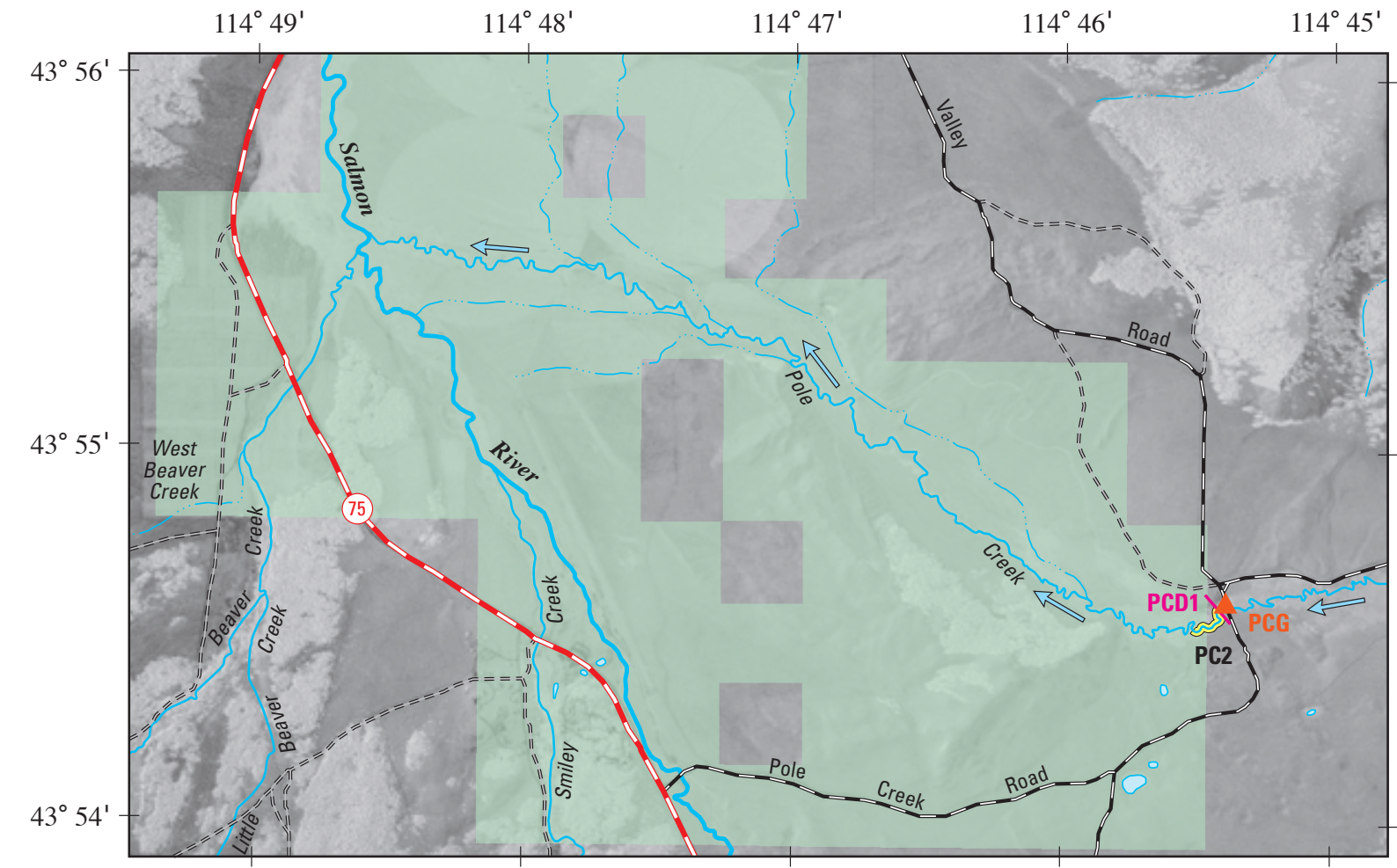

Base from U.S. Geological Survey digital data; 1998; 1:40,000

Transverse Mercator projection; Factor at central meridian: 0.99960;

Longitude of central meridian: $-114^{\circ} 00^{\prime}$; Latitude of origin: $42^{\circ} 00^{\prime}$

False easting (meters): 500,000; False northing (meters): 100,000

Hydrography from U.S. Geological Survey; 1999; 1:24,000
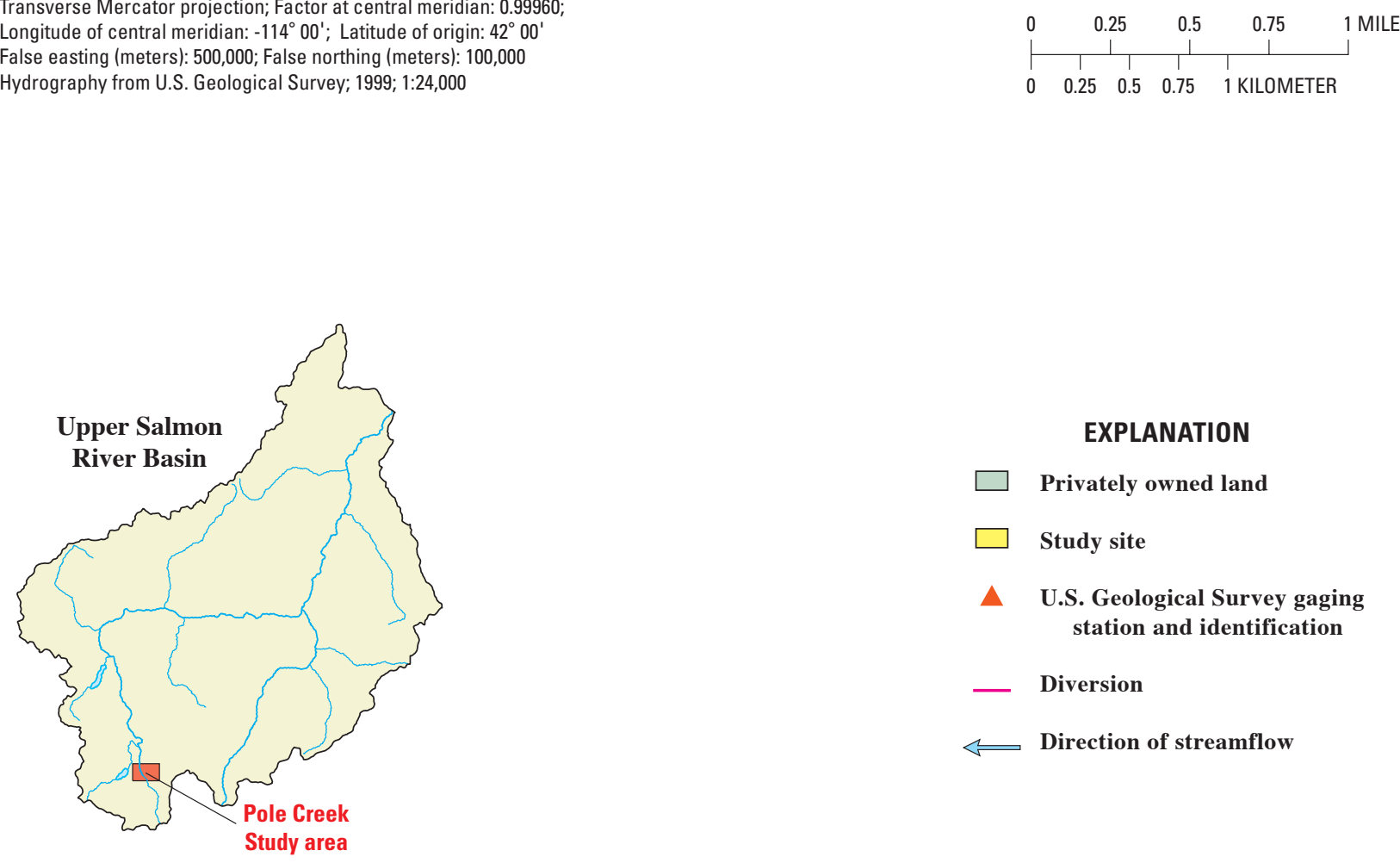

\section{EXPLANATION}

Privately owned land

Study site

$\Delta \quad$ U.S. Geological Survey gaging station and identification

- Diversion

$\Longleftarrow$ Direction of streamflow

Figure 4. Pole Creek study site, diversion, and gaging station location, upper Salmon River Basin, Idaho, 2003 (Basin and site characteristics shown in table 1) 


\section{Pole Creek (Click here for abbreviations used in figures $1 \mathrm{~A}-9 \mathrm{~A}$ and tables $1 \mathrm{~A}-2 \mathrm{~A}$ )}

Pole Creek is a westerly flowing tributary to the Salmon River and is located approximately $10 \mathrm{mi}$ downstream from the Salmon River headwaters (figure 1). Pole Creek originates in the White Cloud Peaks on the east side of the Sawtooth Valley. The upper Pole Creek Basin covers about $18.6 \mathrm{mi}^{2}$, of which about 74 percent is forest. The basin has a mean elevation of $8,477 \mathrm{ft}$ above sea level and receives a mean of about 30 in. of precipitation per year.

\section{Hydrology During 2003}

A short-term streamflow gaging station (13292380) was installed and operated on upper Pole Creek during the period June 1 through October 6, 2003. The gage was located upstream from all active diversions and about $3.5 \mathrm{mi}$ upstream from the confluence with the Salmon River (figure 4; PCG). Stage data were collected at 15-minute intervals and five instantaneous discharge measurements were completed. Stage-discharge relations from the instantaneous measure- mnts were used to determine discharges at each 15-minute interval, resulting in a continuous record of streamflow. A plot of the continuous daily mean discharge in upper Pole Creek upstream from the diversions during WY03 is presented in figure 5 , along with markers indicating the times when field data were collected at the study site. The study site was located about $200 \mathrm{ft}$ downstream from the gaging station and just downstream from the single active Pole Creek diversion (PCD1).

Additional analyses were completed to relate streamflows in upper Pole Creek during WY03 to long-term mean streamflows. Comparisons of July, August, and September monthly mean discharge during WY03 with long-term monthly mean discharge measured at the Valley Creek at Stanley gaging station (13295000) showed that WY03 monthly means were $25.3,20.9$, and 18.1 percent below the long-term monthly means, respectively. These values are slightly higher than the previously discussed snowpack values, which shows that snowpack levels during WY03 were between 4 and 22 percent below the long-term average. This is likely due to the fact that, in addition to current runoff conditions, late summer base flows also are affected by residual conditions from

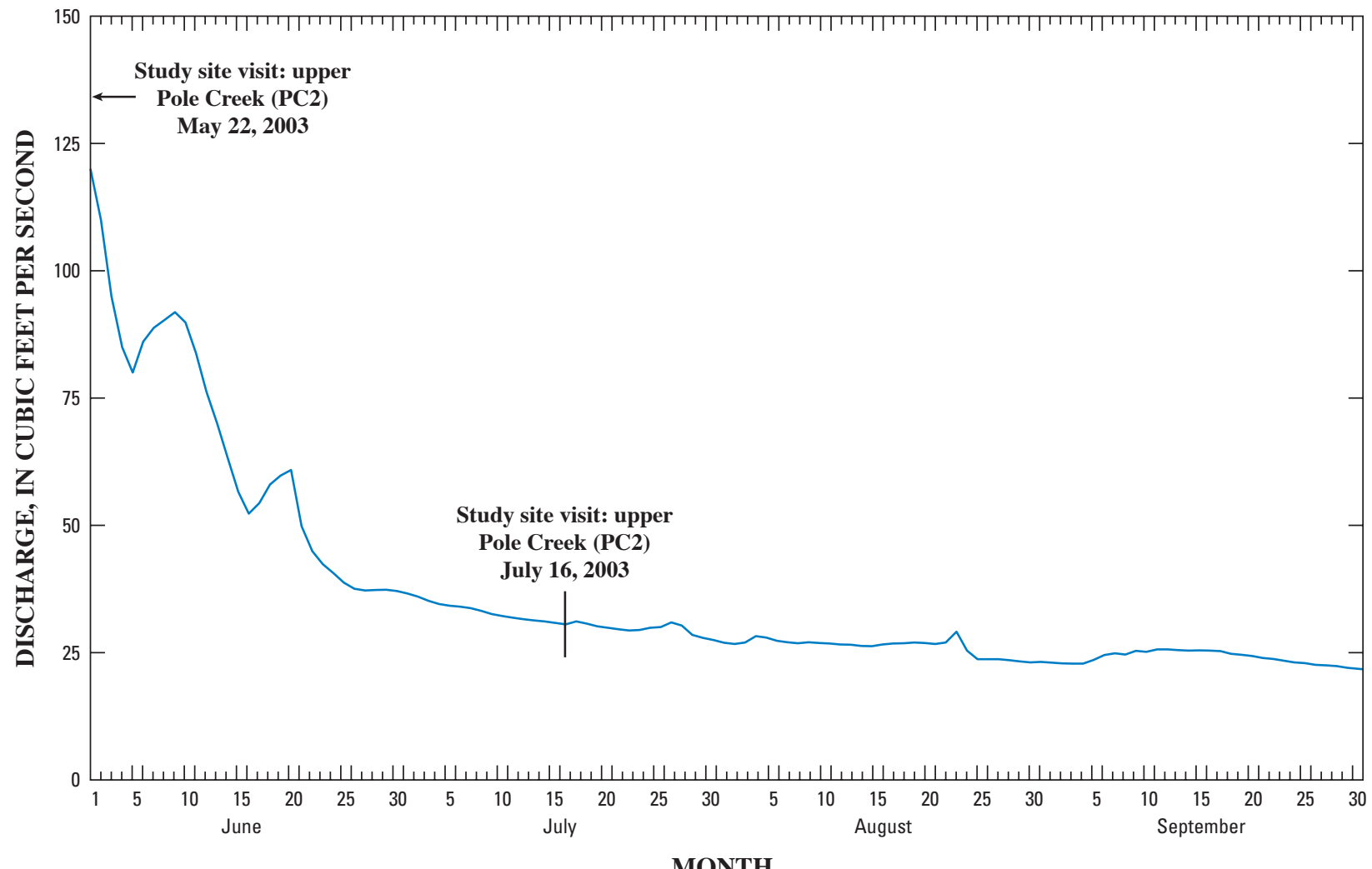

Figure 5. Daily mean discharge at upper Pole Creek below Pole Creek Ranger Station near Obsidian (13292380), upper Salmon River Basin, Idaho, June 1 through September 30, 2003 


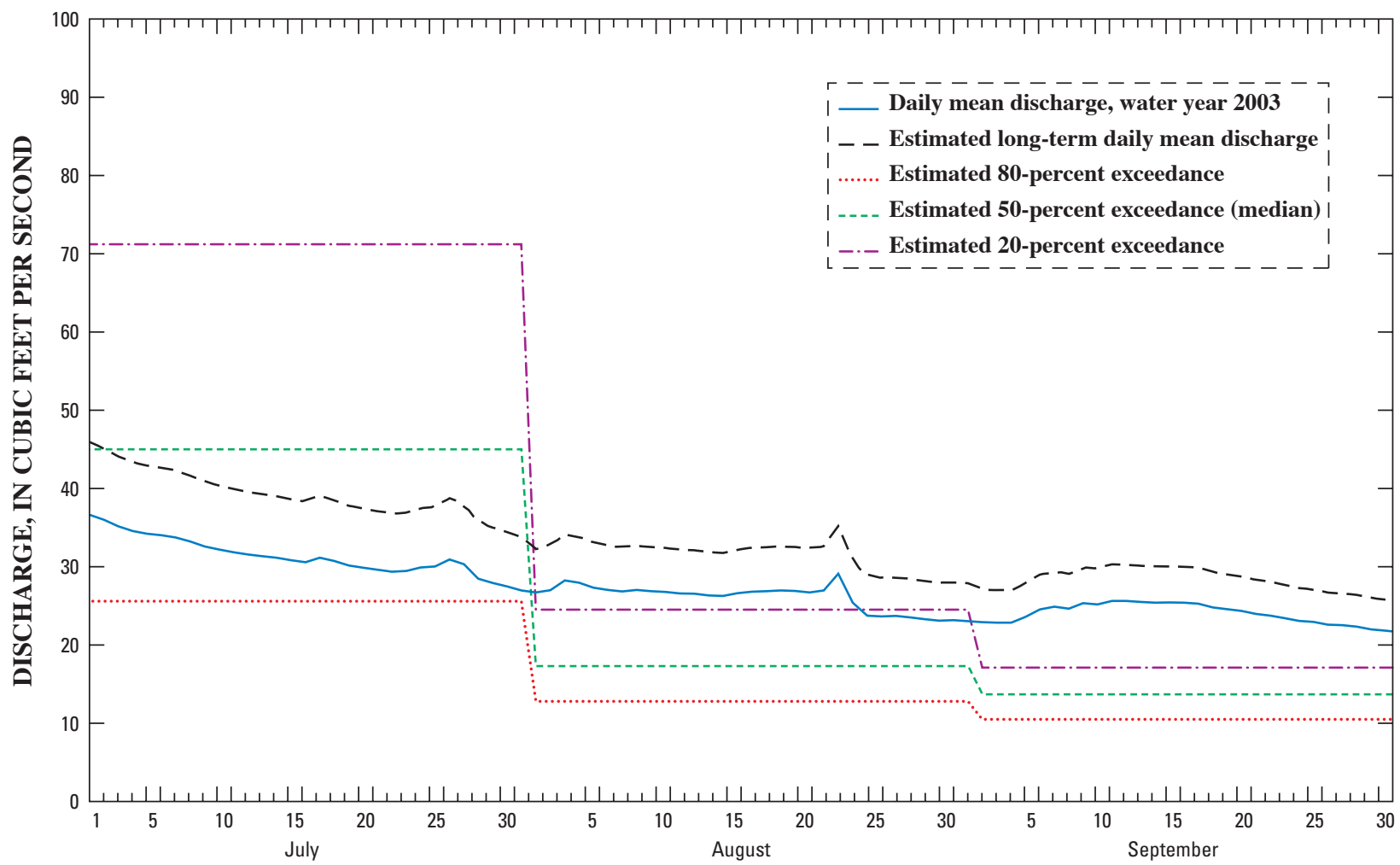

MONTH

Figure 6. Daily mean discharge for water year 2003, estimated long-term daily mean discharge, and estimated 80-, 50-, and 20-percent exceedance statistics for upper Pole Creek below Pole Creek Ranger Station near Obsidian (13292380), upper Salmon River Basin, Idaho, July 1 through September 30 (Estimates based on regional regression equations developed by Hortness and Berenbrock, 2001)

Table 2. Calculated and estimated 80-, 50-, and 20-percent monthly exceedance discharge values for Pole Creek below Pole Creek Ranger Station near Obsidian (13292380), upper Salmon River Basin, Idaho, 2003

[Q, discharge: values presented in cubic feet per second]

\begin{tabular}{|c|c|c|c|c|c|c|c|c|c|c|}
\hline & & \multicolumn{3}{|c|}{ July } & \multicolumn{3}{|c|}{ August } & \multicolumn{3}{|c|}{ September } \\
\hline & & 0.80 & 0.50 & 0.20 & 0.80 & 0.50 & 0.20 & 0.80 & 0.50 & 0.20 \\
\hline & Water year 2003 & 29.6 & 30.9 & 33.7 & 23.7 & 26.7 & 27.0 & 22.8 & 24.2 & 25.3 \\
\hline \multirow{2}{*}{ 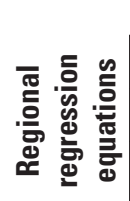 } & Upper confidence limit & 39.6 & 65.1 & 99.3 & 21.8 & 27.4 & 36.7 & 18.4 & 19.9 & 24.1 \\
\hline & Estimate & 25.6 & 45.0 & 71.2 & 12.8 & 17.3 & 24.5 & 10.5 & 13.7 & 17.1 \\
\hline
\end{tabular}

${ }^{1}$ Estimate based on comparisons between water year 2003 and long-term monthly mean discharges at Valley Creek at Stanley (13295000). 
previous years. In this case, several years of below-average streamflow in the upper Salmon River Basin prior to WY03 likely resulted in late summer base flows that were below the long-term average.

To determine an estimated "long-term daily mean" (normal year) hydrograph for upper Pole Creek, the daily mean values for July, August, and September for WY03 were adjusted upward on a monthly basis by the percent differences calculated for the Valley Creek at Stanley gaging station. In other words, all of the daily mean values for upper Pole Creek for July were increased by 25.3 percent; all of the August values were increased by 20.9 percent; and all of the September values were increased by 18.1 percent. The use of the Valley Creek at Stanley gaging station as an "index" station for short-term gaging stations in the upper Salmon River Basin is supported by Berenbrock's (2003) report. The July, August, and September daily mean discharge hydrograph for upper Pole Creek below Pole Creek Ranger Station (13292380) for WY03 and the estimated long-term daily mean hydrograph are presented in figure 6. Also presented in figure 6 are estimated monthly streamflow exceedance statistics for the gaging station location based on regional regression equations developed by Hortness and Berenbrock (2001).

The statistical values plotted in figure 6 include the lower confidence limit for the 80-percent exceedance discharge estimate, the 50-percent exceedance discharge estimate (median), and the upper confidence limit for the 20-percent exceedance discharge estimate. The median estimate gives an indication of long-term average streamflow conditions. During baseflow periods that are absent of peaks, the median and mean streamflow values should be similar. The other estimates provide an indication of the probable variation in streamflows at this location. The confidence limits for the regression equations are based on one standard error of the estimate, which may be wrong on average approximately one time out of three (Ezekial and Fox, 1959). They also are referred to as the 67-percent confidence limits.

The 80-, 50-, and 20-percent monthly exceedance discharge values were estimated on the basis of WY03 daily mean discharge values and estimated long-term daily mean discharge values at the upper Pole Creek gaging station (13292380) (table 2). Exceedance estimates, along with the confidence limits, also were derived from the regional regression equations (Hortness and Berenbrock, 2001) for this location (table 2). Comparison between the estimated long-term daily mean discharge values and values calculated on the basis of the regression equations can provide some insight as to the applicability of the regression equations for upper Pole Creek. As was apparent in figure 6, the regression estimates tend to be lower than the estimated long-term values, indicating that the equations, to some degree, could underestimate streamflow conditions in upper Pole Creek.

Although seepage analyses were not within the scope of this project, instantaneous discharge measurements provide some indication of the amount of streamflow being diverted
Table 3. Miscellaneous discharge measurements collected on Pole Creek, upper Salmon River Basin, Idaho, 2003

[Basin and site characteristics shown in table 1; locations shown in figure 4; PCG, Pole Creek at U.S. Geological Survey gage; PC2, Upper Pole Creek; values presented in cubic feet per second; - , no data available]

\begin{tabular}{c|c|c}
\hline Date & PCG $^{1}$ & PC2 \\
\hline $5 / 22 / 03$ & - & 30.8 \\
\hline $7 / 16 / 03$ & $\underline{30.6}$ & 9.15 \\
\hline $7 / 31 / 03$ & $\underline{27.0}$ & - \\
\hline
\end{tabular}

${ }^{1}$ Daily mean discharge values are underlined.

during the study period. A summary of all discharge measured in Pole Creek during the study period is presented in table 3.

\section{Habitat Modeling and Passage Results}

Upper Pole Creek (PC2) discharges required for maximum WUA ranged from 7 to $17 \mathrm{ft}^{3} / \mathrm{s}, 7$ to $29 \mathrm{ft}^{3} / \mathrm{s}$, and 9 to $29 \mathrm{ft}^{3} / \mathrm{s}$ for bull trout, chinook salmon, and steelhead trout life stages, respectively (table 4). Pool habitat made up about 18 percent of the stream segment surveyed, indicating this stream may have limited juvenile rearing habitat. Discharges required for passage over shallow riffle habitat ranged from 25 to $5 \mathrm{ft}^{3} / \mathrm{s}$ for the depth criterion of $0.6 \mathrm{ft}$ over 25 percent of the total channel width and over 10 percent of the contiguous channel width, respectively (see transect 2 photo at http:/l id.water.usgs.gov/projects/salmon_streamflow). Scott and others (1981), using a passage criterion similar to that used in this study, estimated that a discharge of $23 \mathrm{ft}^{3} / \mathrm{s}$ would provide passage for chinook salmon. For more information summarizing results of this study, see the appendices, figure 1A, figure 9A, and table $1 \mathrm{~A}$ and table $2 \mathrm{~A}$.

Pole Creek no longer sustains runs of anadromous fish. According to Munther (1974), the lack of anadromous stocks in Pole Creek could be attributable to historical dewatering of the lower $2.5 \mathrm{mi}$ of this stream. During his 1973 study, he noted that streamflows upstream from all diversions in Pole Creek stabilized at about $20 \mathrm{ft} 3 / \mathrm{s}$; however, at the mouth downstream from all diversions, flow had been reduced to less than $1 \mathrm{ft}^{3} / \mathrm{s}$ from June 15 through at least mid-September. According to Scott and others (1981), Pole Creek is considered the highest quality fishery habitat within the SNRA and has great potential to accommodate spawning of anadromous fish. However, this potential may be realized only if additional summer flows are provided to allow passage out of the Salmon River into spawning areas.

Summer (July through September) discharges for PC2 were estimated on the basis of regression equations and are listed in table 4. Median discharge (Q.50) estimates for the 
Table 4. Habitat and discharge measurements for upper Pole Creek (PC2), upper Salmon River Basin, Idaho, 2003

[WUA, weighted usable area; $\mathrm{ft}^{3} / \mathrm{s}$, cubic feet per second. WUA maximum discharge estimates were based on Physical Habitat Simulation Model output; Q.xx, daily discharge exceeded $\mathrm{xx}$ percent of the time during the specified month, in $\mathrm{ft}^{3} / \mathrm{s}$; Qa, mean annual discharge, in $\mathrm{ft}^{3} / \mathrm{s}$; ND, not determined]

\begin{tabular}{|c|c|c|c|c|c|c|c|c|c|c|c|c|c|c|c|}
\hline \multirow[b]{3}{*}{ Life stage } & \multicolumn{3}{|c|}{$\begin{array}{l}\text { Discharge, in } \mathrm{ft}^{3} / \mathrm{s} \text {, } \\
\text { required for maximum WUA }\end{array}$} & \multicolumn{2}{|c|}{$\begin{array}{l}\text { Discharge re- } \\
\text { quired for } \\
\text { adult salmonid } \\
\text { passage using } \\
0.6 \text { foot depth } \\
\text { criterion }^{1}\end{array}$} & \multicolumn{10}{|c|}{ Statistical summary of discharge ${ }^{2}$} \\
\hline & \multirow[b]{2}{*}{$\begin{array}{l}\text { Bull } \\
\text { trout }\end{array}$} & \multirow[b]{2}{*}{$\begin{array}{l}\text { Chinook } \\
\text { salmon }\end{array}$} & \multirow[b]{2}{*}{$\begin{array}{l}\text { Steelhead } \\
\text { trout }\end{array}$} & \multirow{2}{*}{$\begin{array}{c}\text { Over } 25 \\
\text { percent } \\
\text { of total } \\
\text { channel } \\
\text { width }\end{array}$} & \multirow{2}{*}{$\begin{array}{c}\text { Over } 10 \\
\text { percent } \\
\text { of } \\
\text { contigu- } \\
\text { ous } \\
\text { channel } \\
\text { width }\end{array}$} & \multicolumn{3}{|c|}{ July } & \multicolumn{3}{|c|}{ August } & \multicolumn{3}{|c|}{ September } & \multirow[b]{2}{*}{ Qa } \\
\hline & & & & & & 0.80 & 0.50 & 0.20 & 0.80 & 0.50 & 0.20 & 0.80 & 0.50 & 0.20 & \\
\hline Adult & 7 & 23 & 23 & 25 & 5 & 25.6 & 45.0 & 71.2 & 12.8 & 17.3 & 24.5 & 10.5 & 13.7 & 17.1 & 43.6 \\
\hline
\end{tabular}

${ }^{1}$ Passage criterion from Thompson (1972) and Scott and others (1981); depth over both width measurements must be met to ensure passage.

${ }^{2}$ Discharge statistics derived from regional regression equations using basin and climatic characteristics (Hortness and Berenbrock, 2001).

months of July, August, and September are 45.0, 17.3, and $13.7 \mathrm{ft}^{3} / \mathrm{s}$, respectively. The mean annual discharge estimate is $43.6 \mathrm{ft}^{3} / \mathrm{s}$. As indicated earlier, on the basis of WY03 data, the regression equations might, to some degree, underestimate streamflow statistics for upper Pole Creek. If deemed necessary, it would be possible to adjust the resulting streamflow statistics for various locations along Pole Creek on the basis of comparison information provided in figure 6 and table 2 . However, any adjustments would be somewhat crude, because they would be based on only 1 partial year of streamflow data.

\section{Stream Temperature Results}

Two data loggers were deployed in upper Pole Creek in 2003 (figure 4). One data logger was deployed near the USGS short-term gaging station (PCG) upstream from all diversions, and another was deployed at the PHABSIM study site PC2 about $200 \mathrm{ft}$ downstream from the diversion (PCD1). Both data loggers were deployed in mid-June and retrieved in late September. After the data were downloaded, June 25 through September 28 (96 days) was selected as the period of record for calculating stream temperature metrics.
Analysis of the stream temperature metrics for upper Pole Creek indicated a slight warming trend downstream from PCG to PC2 (figure 7). However, the increase in stream temperature was only slightly higher than the measurement error associated with the temperature recording data logger $\left( \pm^{-} 0.4\right)$ and is within the uncertainty range of the predicted temperatures from the SSTEMP model. Thus, the stream temperature model was not applied to Pole Creek.

Results of the individual metric calculations showed that the MDMT was $14.8^{\circ} \mathrm{C}$ at PCG and $15.5^{\circ} \mathrm{C}$ at PC2, occurring on July 21 at both sites, and was well below the MDMT of $21.0^{\circ} \mathrm{C}$ that, according to Poole and others (2001), can create a thermal barrier that would block adult chinook salmon from migrating to their spawning grounds. Also, the MDMT never exceeded the $18.0^{\circ} \mathrm{C}$ threshold that may block bull trout migration (J. Dunham, U.S. Forest Service, written commun., 2004). No stream temperatures at either location exceeded the IDEQ $19.0^{\circ} \mathrm{C}$ MDAT and $22.0^{\circ} \mathrm{C}$ MDMT criteria for the protection of coldwater biota during the period of record. A summary of the individual temperature metrics for all study sites can be accessed at http:/|id.water.usgs.gov/projects| salmon_streamflow 


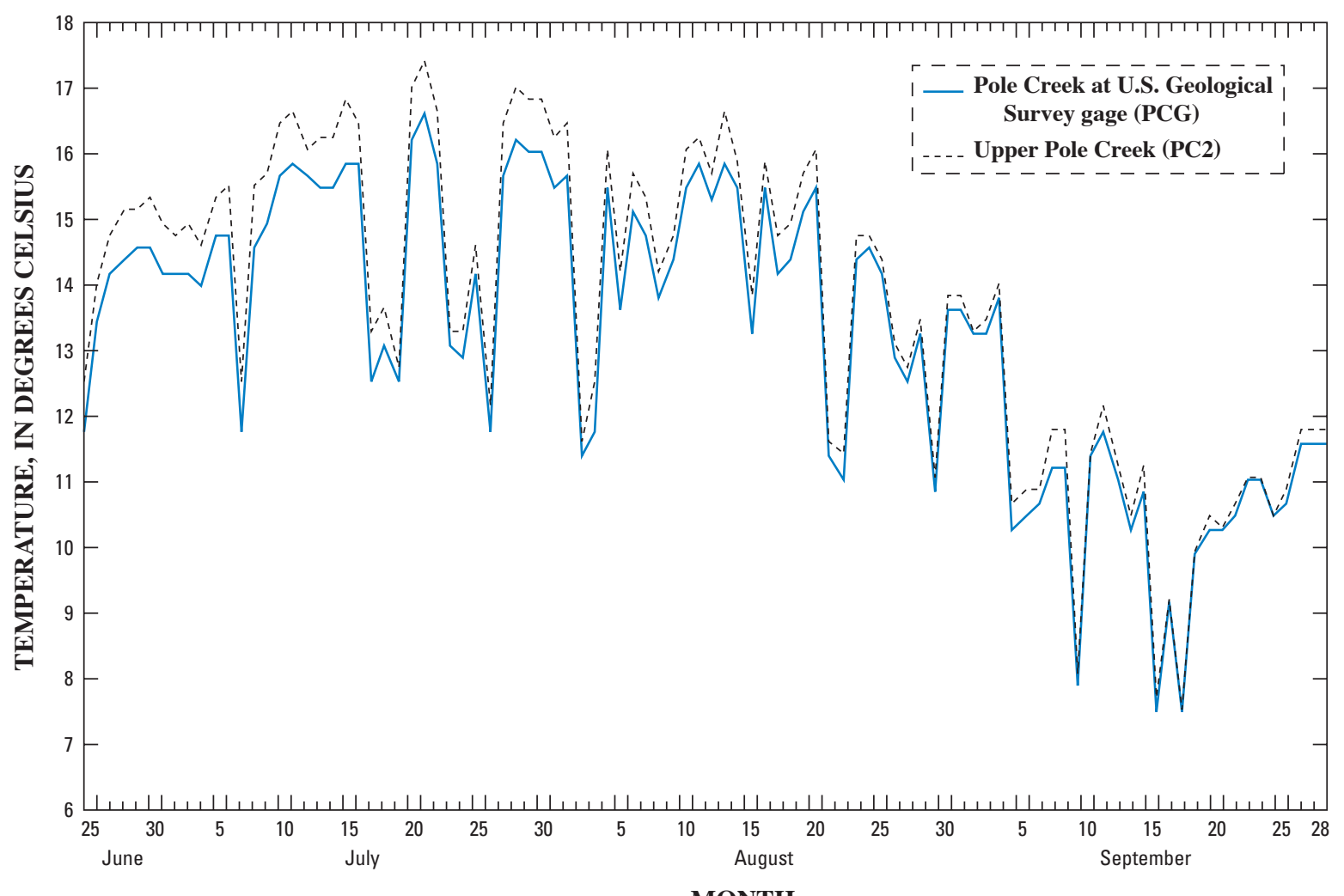

Figure 7. Maximum daily water temperature for period June 25 through September 28, 2003, at Pole Creek, upper Salmon River Basin, Idaho

\section{Pole Creek Appendix Abbreviations}

Contiguous, continuous width with equal or greater water depth

Discharge, in $\mathrm{ft}^{3} / \mathrm{s}$

$\mathrm{ft}$, feet

$\mathrm{ft}^{2}$, square feet

$\mathrm{ft}^{3} / \mathrm{s}$, cubic feet per second

PC2, site number (see table 1)

RM1, local reference mark

Stream width, in $\mathrm{ft}$

T1, transect number

Total Area, study site area, in $\mathrm{ft}^{2}$

WUA, weighted usable area, in $\mathrm{ft}^{2}$ per $1,000 \mathrm{ft}$ of stream 


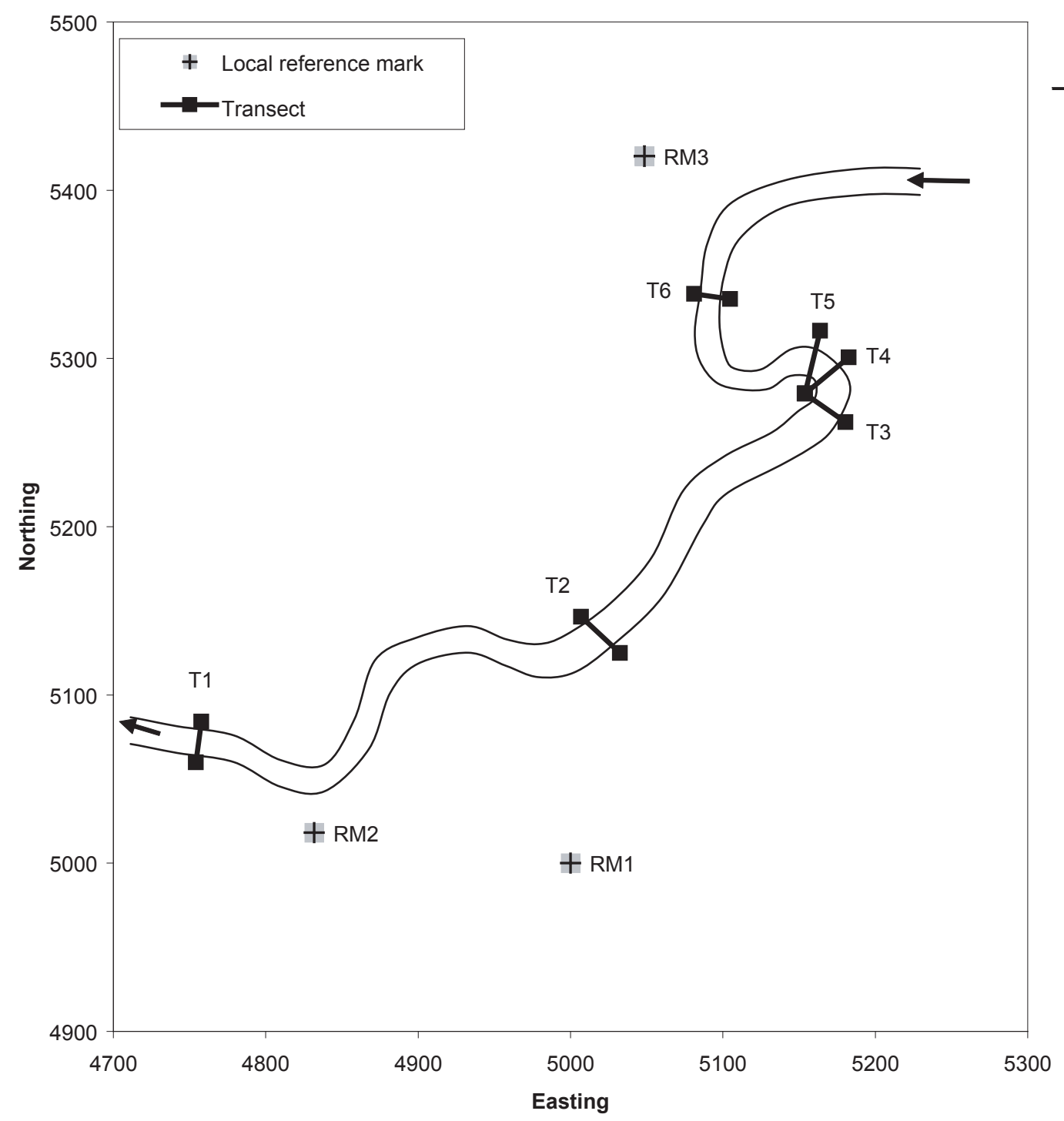

Transect Endpoint Coordinates (NAD 83)

\begin{tabular}{ccc} 
Point & Latitude & Longitude \\
\hline LB T1 & $114^{\circ} 45^{\prime} 30.19^{\prime \prime} \mathrm{W}$ & $43^{\circ} 54^{\prime} 31.38^{\prime \prime} \mathrm{N}$ \\
RB T1 & $114^{\circ} 45^{\prime} 30.21^{\prime \prime} \mathrm{W}$ & $43^{\circ} 54^{\prime} 31.14^{\prime \prime} \mathrm{N}$ \\
LB T2 & $114^{\circ} 45^{\prime} 26.84^{\prime \prime} \mathrm{W}$ & $43^{\circ} 54^{\prime} 32.15^{\prime \prime} \mathrm{N}$ \\
RB T2 & $114^{\circ} 45^{\prime} 26.47^{\prime \prime} \mathrm{W}$ & $43^{\circ} 54^{\prime} 31.95^{\prime \prime} \mathrm{N}$ \\
LB T3 & $114^{\circ} 45^{\prime} 24.95^{\prime \prime} \mathrm{W}$ & $43^{\circ} 54^{\prime} 33.55^{\prime \prime} \mathrm{N}$ \\
RB T3 & $114^{\circ} 45^{\prime} 24.57^{\prime \prime} \mathrm{W}$ & $43^{\circ} 54^{\prime} 33.40^{\prime \prime} \mathrm{N}$ \\
LB T4 & $114^{\circ} 45^{\prime} 24.95^{\prime \prime} \mathrm{W}$ & $43^{\circ} 54^{\prime} 33.55^{\prime \prime} \mathrm{N}$ \\
RB T4 & $114^{\circ} 45^{\prime} 24.57^{\prime \prime} \mathrm{W}$ & $43^{\circ} 54^{\prime} 33.78^{\prime \prime} \mathrm{N}$ \\
LB T5 & $114^{\circ} 45^{\prime} 24.95^{\prime \prime} \mathrm{W}$ & $43^{\circ} 54^{\prime} 33.55^{\prime \prime} \mathrm{N}$ \\
RB T5 & $114^{\circ} 45^{\prime} 24.83^{\prime \prime} \mathrm{W}$ & $43^{\circ} 54^{\prime} 33.92^{\prime \prime} \mathrm{N}$ \\
LB T6 & $114^{\circ} 45^{\prime} 25.98^{\prime \prime} \mathrm{W}$ & $43^{\circ} 54^{\prime} 34.09^{\prime \prime} \mathrm{N}$ \\
RB T6 & $114^{\circ} 45^{\prime} 25.65^{\prime \prime} \mathrm{W}$ & $43^{\circ} 54^{\prime} 34.08^{\prime \prime} \mathrm{N}$
\end{tabular}

For reference only; stream schematic not to scale. 
Figure 2A

Upper Pole Creek - PC2

Bull Trout WUA

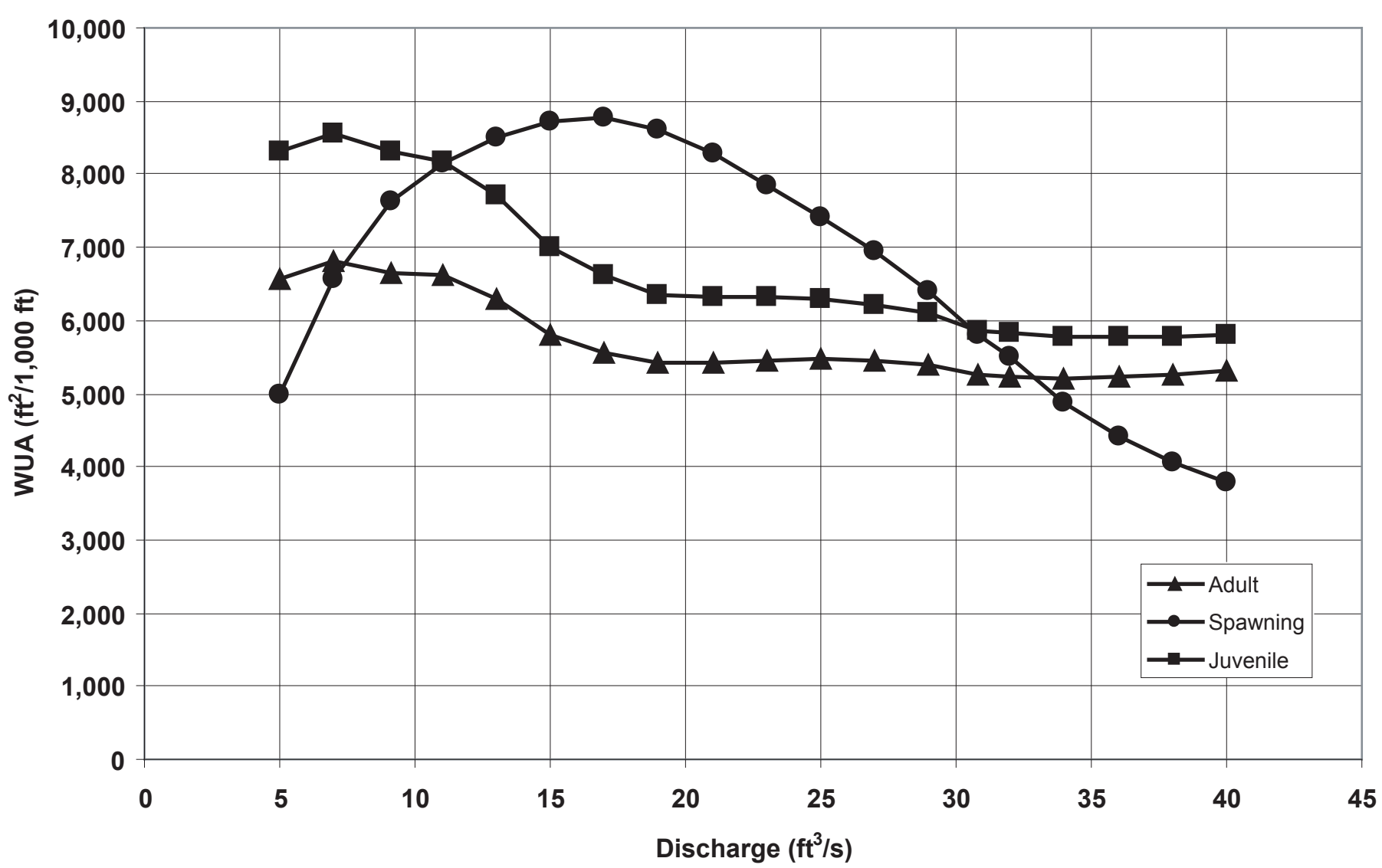


Figure 3A

Upper Pole Creek - PC2

Bull Trout WUA Normalized

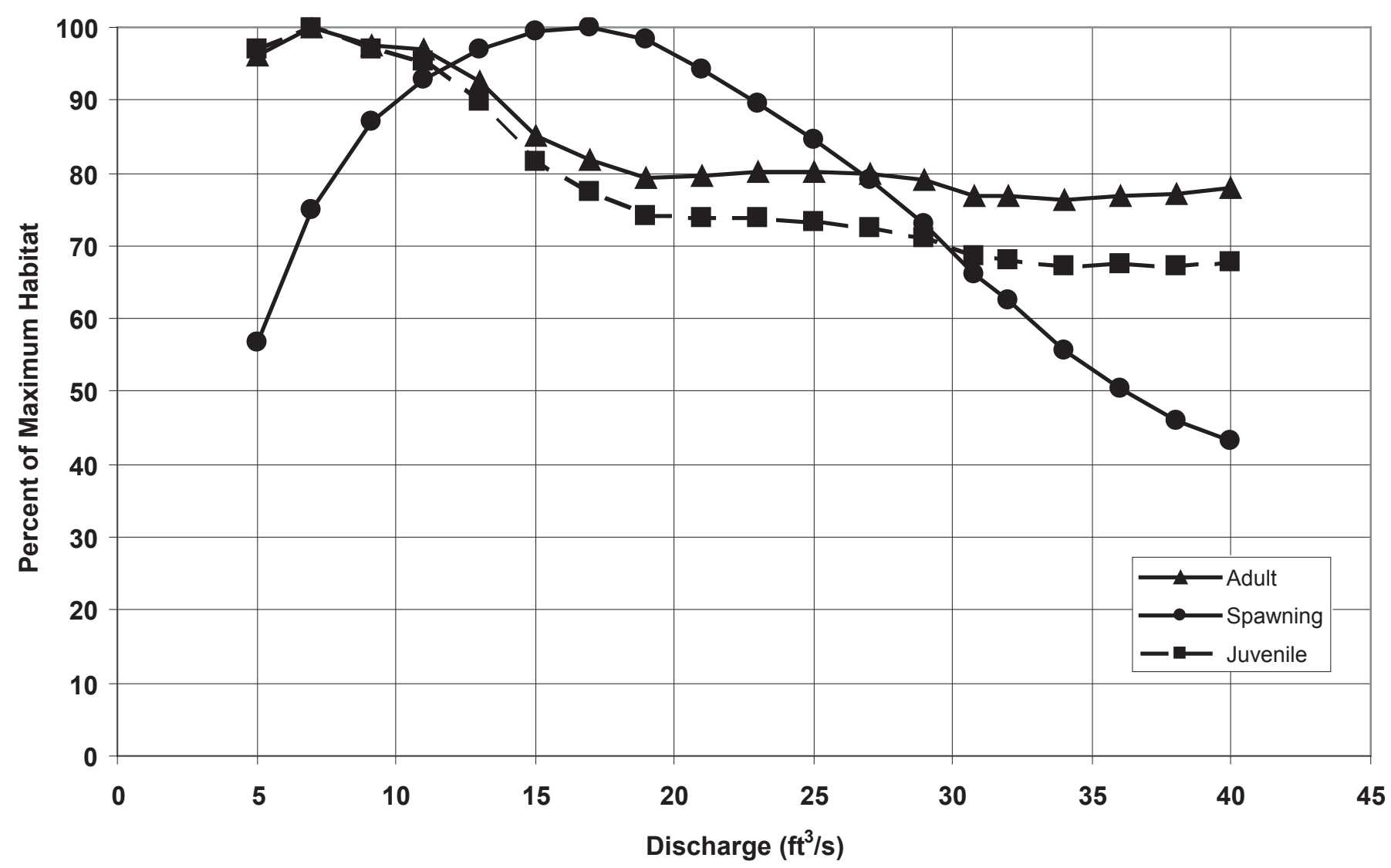


Figure 4A

Upper Pole Creek - PC2

Chinook Salmon WUA

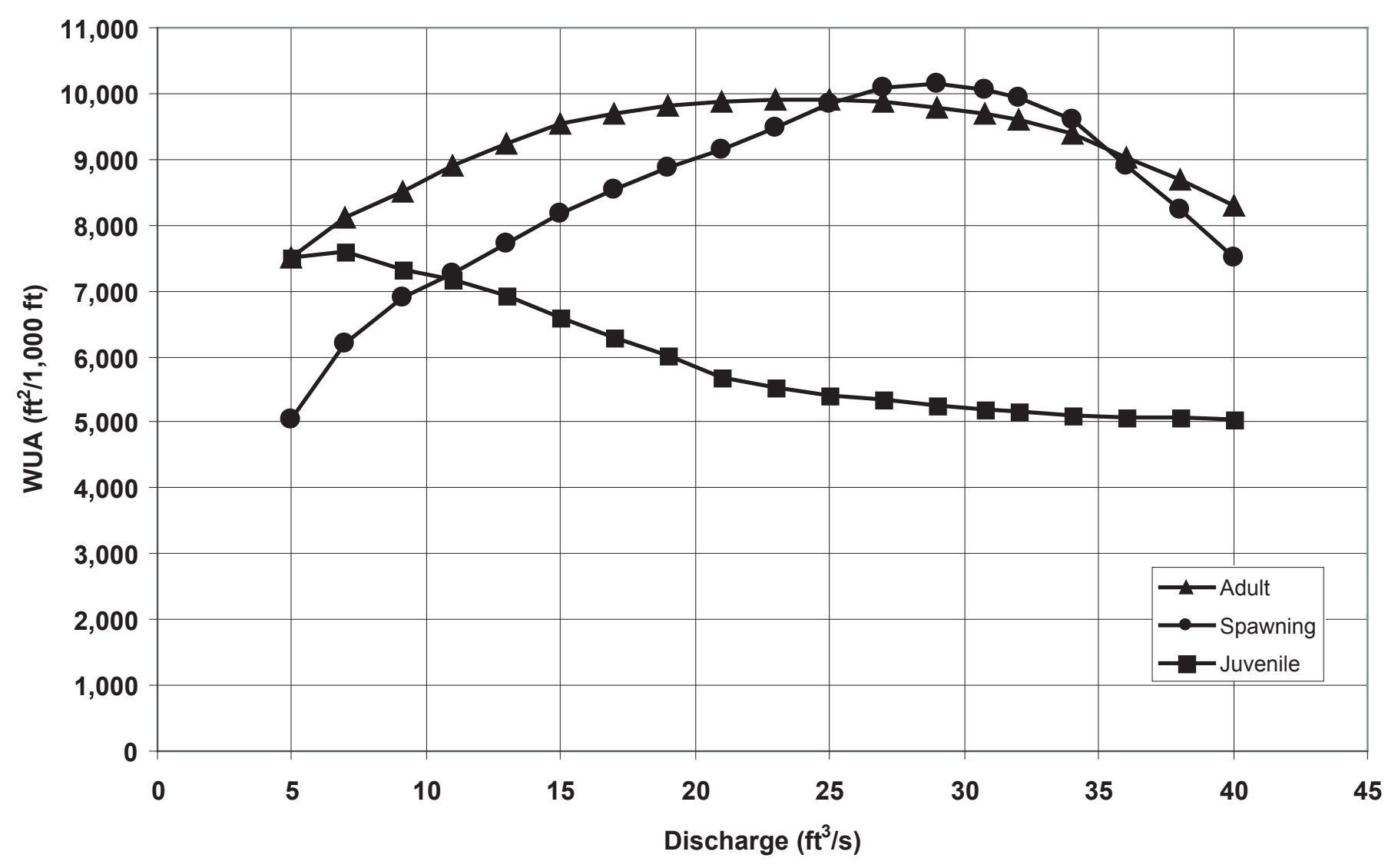


Figure 5A

Upper Pole Creek - PC2

Chinook Salmon WUA Normalized

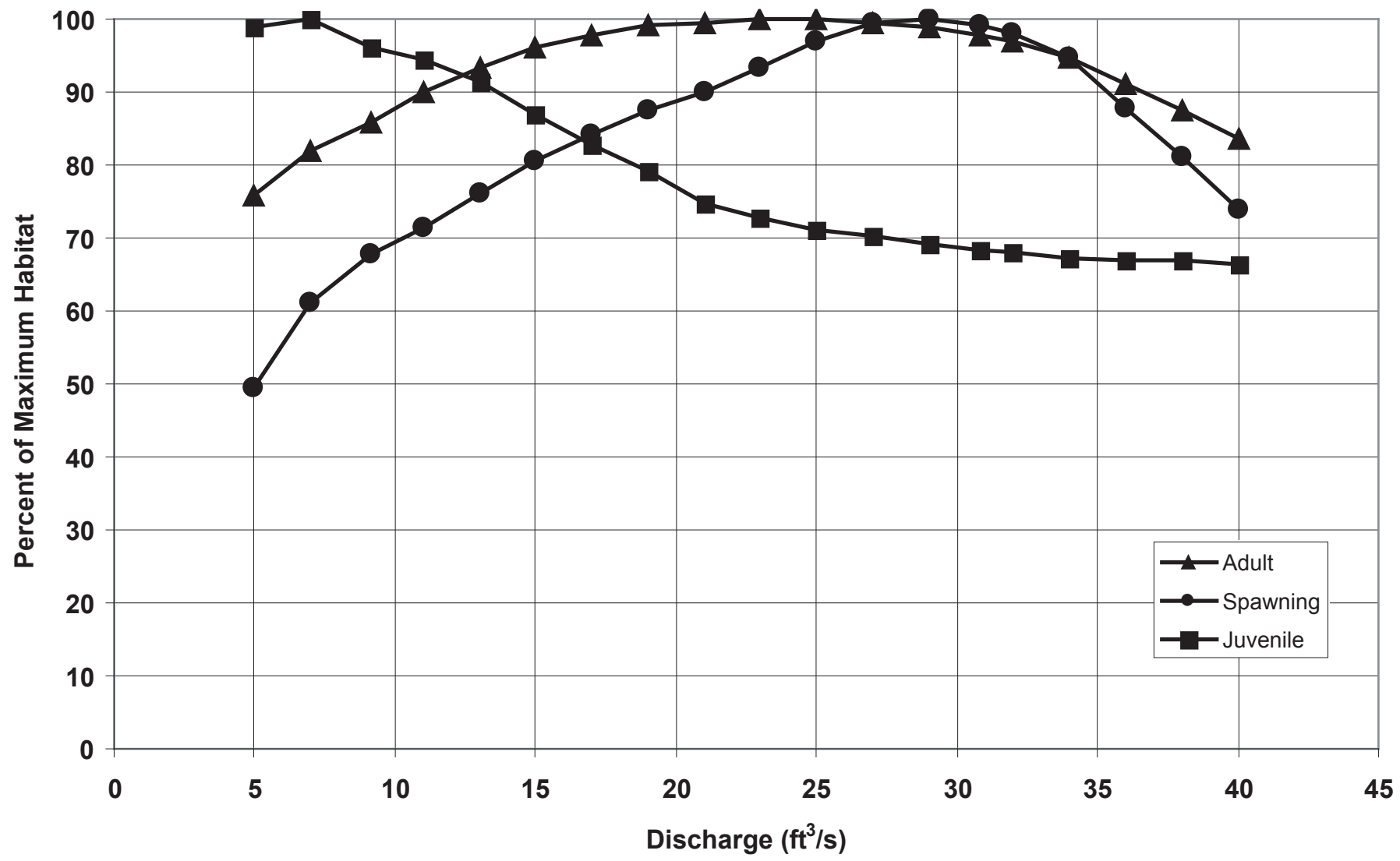


Figure 6A

Upper Pole Creek - PC2

Steelhead WUA

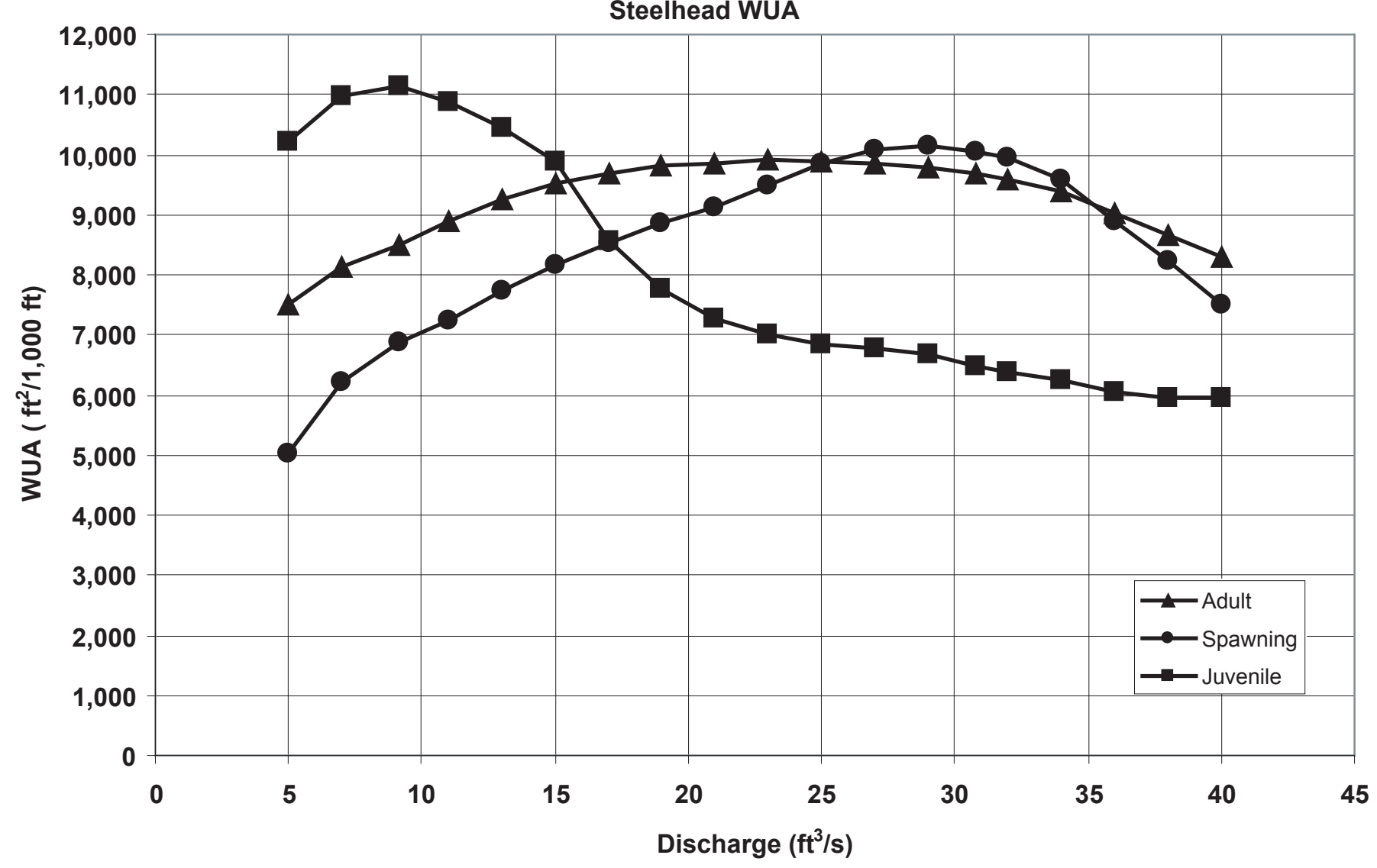


Figure 7A

Upper Pole Creek - PC2

Steelhead WUA Normalized

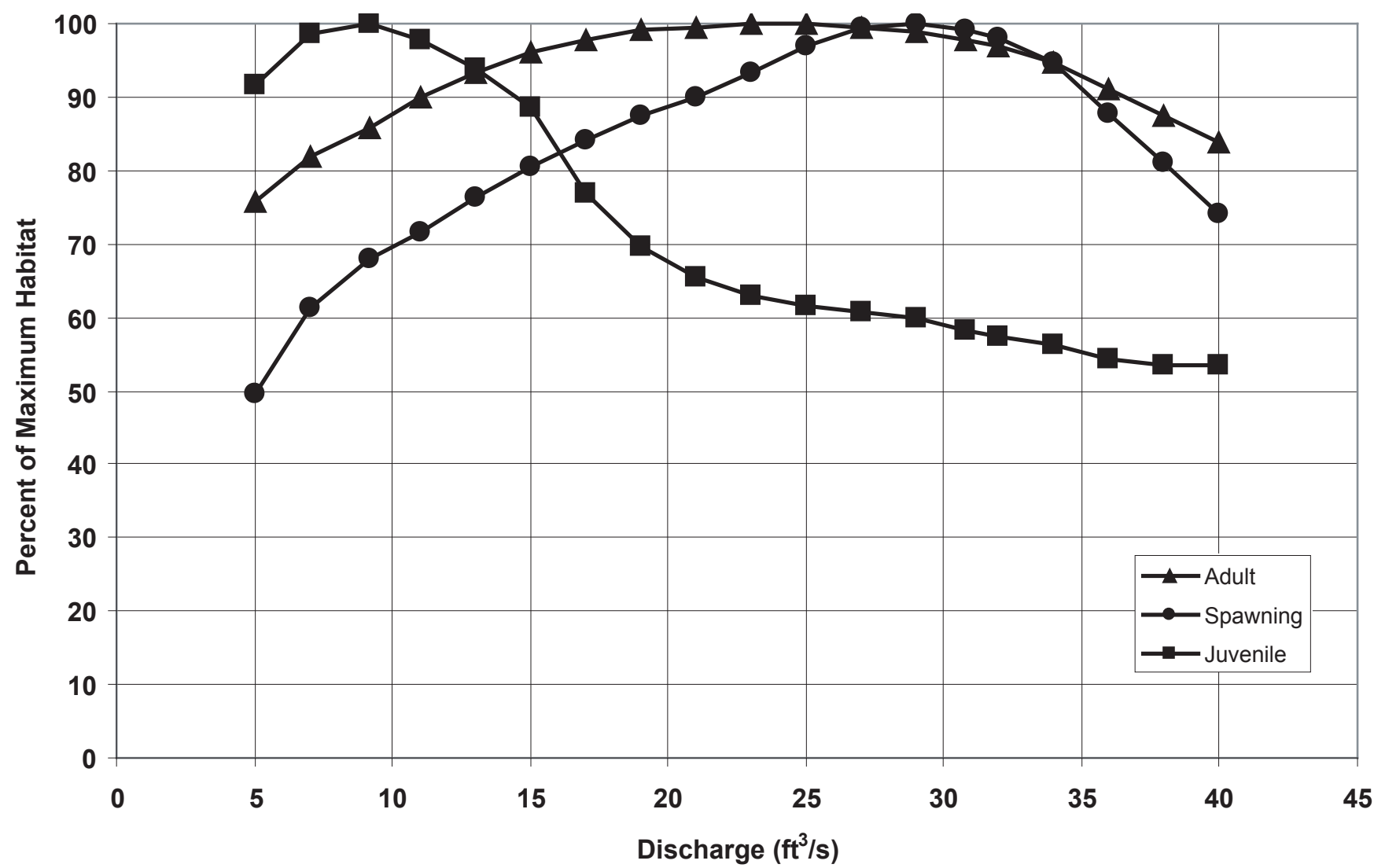


Table 1A. Weighted usable area for bull trout, chinook salmon, steelhead trout life stages, and cover for juvenile life stages, site PC2, upper Pole Creek, 2003

\section{BULL TROUT}

\begin{tabular}{|c|c|c|c|c|c|c|c|c|}
\hline \multirow{2}{*}{$\begin{array}{c}\text { Discharge } \\
\left(\mathrm{ft}^{3} / \mathrm{s}\right)\end{array}$} & \multirow{2}{*}{$\begin{array}{c}\text { Total Area } \\
\left(\mathrm{ft}^{2}\right)\end{array}$} & \multicolumn{4}{|c|}{ Summary of Weighted Usable Area $\left(\mathrm{ft}^{2} / 1000 \mathrm{ft}\right)$} & \multicolumn{3}{|c|}{ Percent of Optimum } \\
\hline & & Adult & Spawning & Juvenile & Cover & Adult & Spawning & Juvenile \\
\hline 5 & 16043.1 & 6559.6 & 4978.4 & 8304.0 & 402.8 & 96.19 & 56.74 & 96.95 \\
\hline 7 & 16519.5 & 6819.3 & 6568.6 & 8565.2 & 492.3 & 100.00 & 74.87 & 100.00 \\
\hline 9.15 & 16659.5 & 6656.2 & 7641.7 & 8301.0 & 523.7 & 97.61 & 87.10 & 96.92 \\
\hline 11 & 16811.7 & 6614.1 & 8149.2 & 8173.7 & 540.3 & 96.99 & 92.89 & 95.43 \\
\hline 13 & 16909.9 & 6302.8 & 8504.0 & 7701.2 & 551.2 & 92.43 & 96.93 & 89.91 \\
\hline 15 & 16997.9 & 5813.3 & 8714.8 & 6992.7 & 579.3 & 85.25 & 99.33 & 81.64 \\
\hline 17 & 17063.3 & 5571.9 & 8773.3 & 6619.4 & 608.3 & 81.71 & 100.00 & 77.28 \\
\hline 19 & 17122.1 & 5415.0 & 8623.6 & 6358.4 & 645.0 & 79.41 & 98.29 & 74.24 \\
\hline 21 & 17181.0 & 5424.9 & 8274.0 & 6323.1 & 651.1 & 79.55 & 94.31 & 73.82 \\
\hline 23 & 17256.9 & 5462.5 & 7844.2 & 6320.6 & 638.3 & 80.10 & 89.41 & 73.79 \\
\hline 25 & 17326.8 & 5473.4 & 7422.8 & 6286.5 & 603.7 & 80.26 & 84.61 & 73.40 \\
\hline 27 & 17395.9 & 5443.2 & 6946.0 & 6203.3 & 598.9 & 79.82 & 79.17 & 72.42 \\
\hline 29 & 17459.2 & 5392.9 & 6406.3 & 6095.2 & 578.9 & 79.08 & 73.02 & 71.16 \\
\hline 30.8 & 17484.5 & 5247.6 & 5807.0 & 5868.1 & 522.3 & 76.95 & 66.19 & 68.51 \\
\hline 32 & 17495.9 & 5240.5 & 5492.2 & 5837.9 & 557.1 & 76.85 & 62.60 & 68.16 \\
\hline 34 & 17513.4 & 5209.4 & 4886.2 & 5765.6 & 573.2 & 76.39 & 55.69 & 67.31 \\
\hline 36 & 17570.3 & 5240.3 & 4419.2 & 5770.3 & 585.4 & 76.85 & 50.37 & 67.37 \\
\hline 38 & 17640.8 & 5264.0 & 4047.1 & 5767.3 & 593.7 & 77.19 & 46.13 & 67.33 \\
\hline 40 & 17709.5 & 5309.9 & 3798.0 & 5797.6 & 604.5 & 77.87 & 43.29 & 67.69 \\
\hline
\end{tabular}

\section{CHINOOK SALMON}

\begin{tabular}{|c|c|c|c|c|c|c|c|c|}
\hline \multirow{2}{*}{$\begin{array}{c}\text { Discharge } \\
\left(\mathrm{ft}^{3} / \mathrm{s}\right)\end{array}$} & \multirow{2}{*}{$\begin{array}{c}\text { Total Area } \\
\left(\mathrm{ftt}^{2}\right)\end{array}$} & \multicolumn{4}{|c|}{ Summary of Weighted Usable Area $\left(\mathrm{ft}^{2} / 1000 \mathrm{ft}\right)$} & \multicolumn{3}{|c|}{ Percent of Optimum } \\
\hline & & Adult & Spawning & Juvenile & Cover & Adult & Spawning & Juvenile \\
\hline 5 & 16043.1 & 7507.6 & 5030.6 & 7508.8 & 444.7 & 75.77 & 49.58 & 98.76 \\
\hline 7 & 16519.5 & 8117.1 & 6213.9 & 7602.8 & 495.9 & 81.93 & 61.24 & 100.00 \\
\hline 9.15 & 16659.5 & 8501.2 & 6884.8 & 7312.9 & 521.8 & 85.80 & 67.85 & 96.19 \\
\hline 11 & 16811.7 & 8903.9 & 7250.4 & 7181.4 & 538.7 & 89.87 & 71.46 & 94.46 \\
\hline 13 & 16909.9 & 9252.7 & 7732.7 & 6940.1 & 547.9 & 93.39 & 76.21 & 91.28 \\
\hline 15 & 16997.9 & 9526.4 & 8174.3 & 6608.1 & 551.6 & 96.15 & 80.56 & 86.92 \\
\hline 17 & 17063.3 & 9700.2 & 8544.8 & 6295.6 & 547.6 & 97.90 & 84.21 & 82.81 \\
\hline 19 & 17122.1 & 9813.8 & 8865.3 & 6021.8 & 540.5 & 99.05 & 87.37 & 79.21 \\
\hline 21 & 17181.0 & 9866.0 & 9133.0 & 5689.3 & 529.2 & 99.58 & 90.01 & 74.83 \\
\hline 23 & 17256.9 & 9907.8 & 9481.4 & 5537.5 & 515.0 & 100.00 & 93.44 & 72.84 \\
\hline 25 & 17326.8 & 9900.7 & 9848.9 & 5406.9 & 489.8 & 99.93 & 97.06 & 71.12 \\
\hline 27 & 17395.9 & 9865.7 & 10088.7 & 5336.3 & 481.9 & 99.58 & 99.43 & 70.19 \\
\hline 29 & 17459.2 & 9795.5 & 10146.7 & 5255.2 & 452.9 & 98.87 & 100.00 & 69.12 \\
\hline 30.8 & 17484.5 & 9689.0 & 10060.4 & 5196.2 & 447.5 & 97.79 & 99.15 & 68.35 \\
\hline 32 & 17495.9 & 9600.3 & 9945.4 & 5170.2 & 448.2 & 96.90 & 98.02 & 68.00 \\
\hline 34 & 17513.4 & 9388.2 & 9600.3 & 5117.2 & 450.6 & 94.76 & 94.62 & 67.31 \\
\hline 36 & 17570.3 & 9036.0 & 8907.7 & 5086.6 & 455.2 & 91.20 & 87.79 & 66.90 \\
\hline 38 & 17640.8 & 8676.1 & 8225.9 & 5082.4 & 461.2 & 87.57 & 81.07 & 66.85 \\
\hline 40 & 17709.5 & 8295.4 & 7510.0 & 5049.4 & 459.5 & 83.73 & 74.01 & 66.41 \\
\hline
\end{tabular}


Table 1A. Weighted usable area for bull trout, chinook salmon, steelhead trout life stages, and cover for juvenile life stages, site PC2, upper Pole Creek, 2003 - Continued

\section{STEELHEAD}

\begin{tabular}{|c|c|c|c|c|c|c|c|c|}
\hline \multirow{2}{*}{$\begin{array}{c}\text { Discharge } \\
\left(\mathrm{ft}^{3} / \mathrm{s}\right)\end{array}$} & \multirow{2}{*}{$\begin{array}{c}\text { Total Area } \\
\left(\mathrm{ft}^{2}\right)\end{array}$} & \multicolumn{4}{|c|}{ Summary of Weighted Usable Area ( $\left.\mathrm{ft}^{2} / 1000 \mathrm{ft}\right)$} & \multicolumn{3}{|c|}{ Percent of Optimum } \\
\hline & & Adult & Spawning & Juvenile & Cover & Adult & Spawning & Juvenile \\
\hline 5 & 16043.1 & 7507.6 & 5030.6 & 10199.2 & 504.9 & 75.77 & 49.58 & 91.56 \\
\hline 7 & 16519.5 & 8117.1 & 6213.9 & 10991.3 & 622.8 & 81.93 & 61.24 & 98.67 \\
\hline 9.15 & 16659.5 & 8501.2 & 6884.8 & 11139.8 & 721.3 & 85.80 & 67.85 & 100.00 \\
\hline 11 & 16811.7 & 8903.9 & 7250.4 & 10878.5 & 780.3 & 89.87 & 71.46 & 97.65 \\
\hline 13 & 16909.9 & 9252.7 & 7732.7 & 10455.9 & 832.8 & 93.39 & 76.21 & 93.86 \\
\hline 15 & 16997.9 & 9526.4 & 8174.3 & 9870.8 & 865.2 & 96.15 & 80.56 & 88.61 \\
\hline 17 & 17063.3 & 9700.2 & 8544.8 & 8570.3 & 879.7 & 97.90 & 84.21 & 76.93 \\
\hline 19 & 17122.1 & 9813.8 & 8865.3 & 7769.2 & 896.6 & 99.05 & 87.37 & 69.74 \\
\hline 21 & 17181.0 & 9866.0 & 9133.0 & 7282.5 & 861.0 & 99.58 & 90.01 & 65.37 \\
\hline 23 & 17256.9 & 9907.8 & 9481.4 & 7002.3 & 871.2 & 100.00 & 93.44 & 62.86 \\
\hline 25 & 17326.8 & 9900.7 & 9848.9 & 6848.9 & 824.8 & 99.93 & 97.06 & 61.48 \\
\hline 27 & 17395.9 & 9865.7 & 10088.7 & 6775.0 & 790.2 & 99.58 & 99.43 & 60.82 \\
\hline 29 & 17459.2 & 9795.5 & 10146.7 & 6664.8 & 784.0 & 98.87 & 100.00 & 59.83 \\
\hline 30.8 & 17484.5 & 9689.0 & 10060.4 & 6473.9 & 698.0 & 97.79 & 99.15 & 58.11 \\
\hline 32 & 17495.9 & 9600.3 & 9945.4 & 6387.1 & 710.3 & 96.90 & 98.02 & 57.34 \\
\hline 34 & 17513.4 & 9388.2 & 9600.3 & 6256.7 & 722.1 & 94.76 & 94.62 & 56.17 \\
\hline 36 & 17570.3 & 9036.0 & 8907.7 & 6063.5 & 733.1 & 91.20 & 87.79 & 54.43 \\
\hline 38 & 17640.8 & 8676.1 & 8225.9 & 5956.9 & 746.4 & 87.57 & 81.07 & 53.47 \\
\hline 40 & 17709.5 & 8295.4 & 7510.0 & 5948.2 & 757.5 & 83.73 & 74.01 & 53.40 \\
\hline
\end{tabular}


Figure 8A

Percent of Contiguous Stream Width

Upper Pole Creek - PC2

Passage Transect 2 (wide low slope)

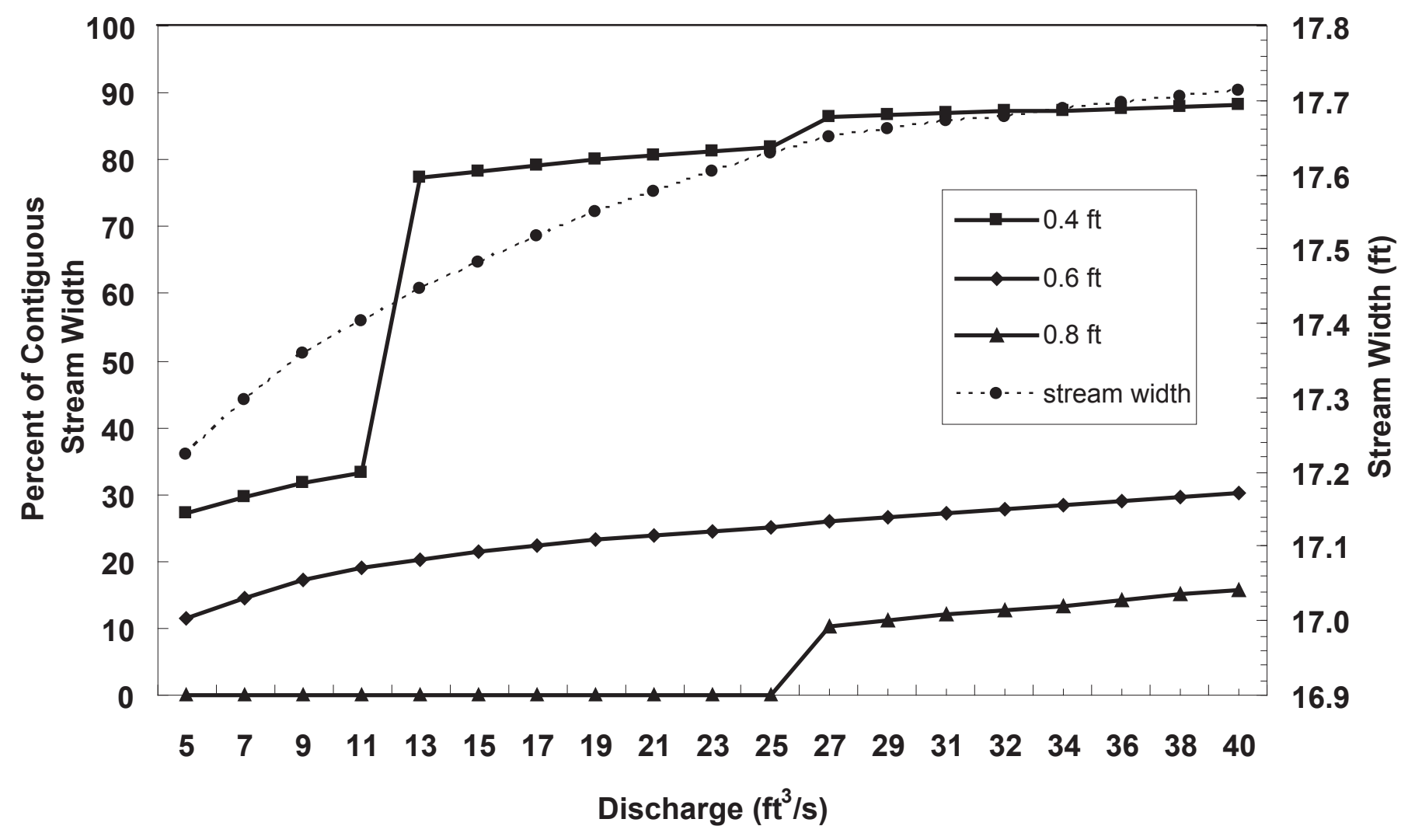


Figure 9A

Percent of Total Stream Width

Upper Pole Creek - PC2

Passage Transect 2 (wide low slope)

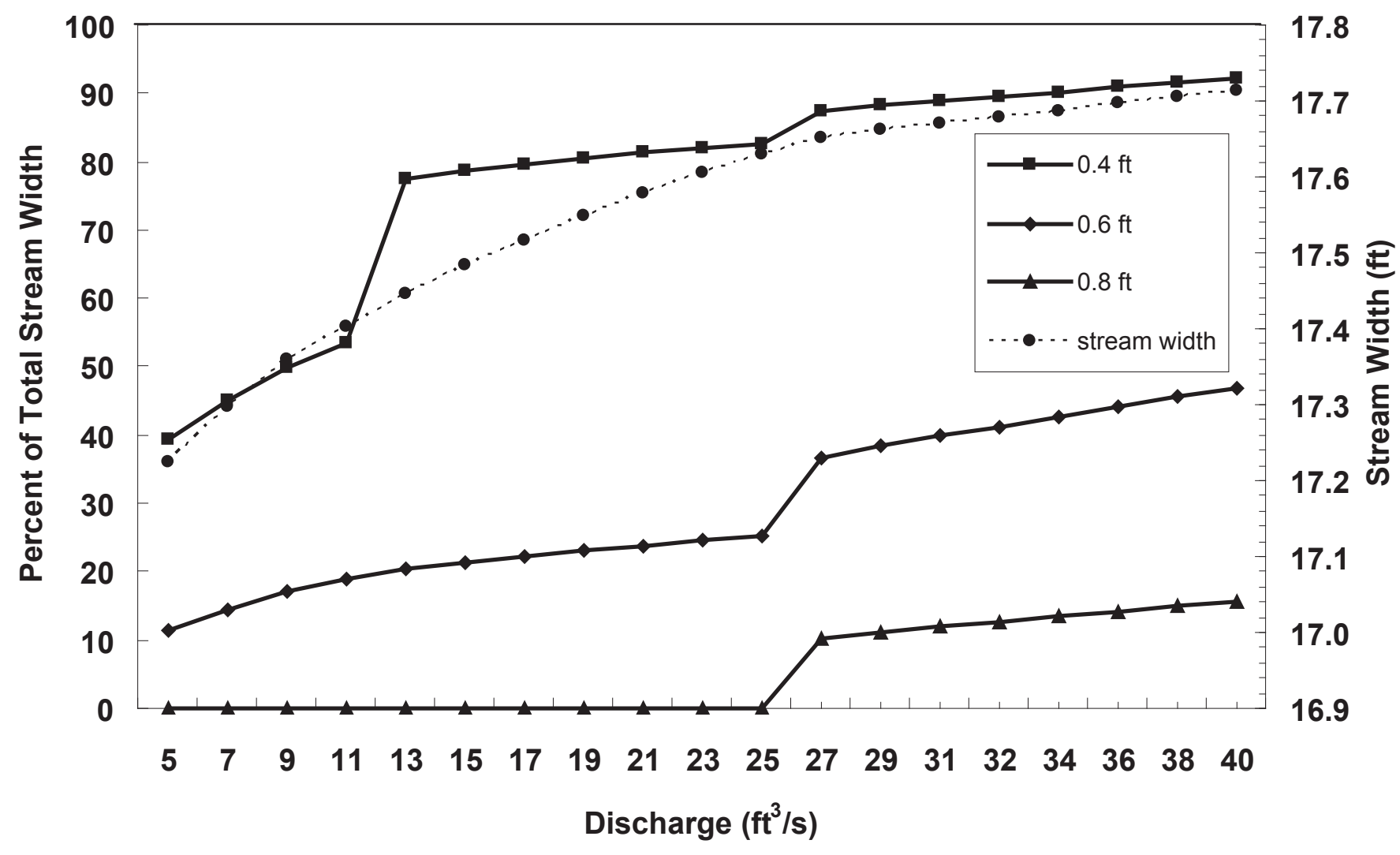


Table 2A. Passage criteria assessment for transect 2 (wide low slope), site PC2, upper Pole Creek, 2003

\begin{tabular}{|c|c|c|c|c|c|}
\hline $\begin{array}{c}\text { Discharge } \\
\left(\mathrm{ft}^{3} / \mathrm{s}\right)\end{array}$ & $\begin{array}{c}\text { Stream width } \\
(\mathrm{ft})\end{array}$ & $\begin{array}{l}\text { Total Stream } \\
\text { Width Greater } \\
\text { Than } 0.4 \mathrm{ft} \text { depth }\end{array}$ & $\begin{array}{l}\text { Percent Stream } \\
\text { Width Greater } \\
\text { Than } 0.4 \mathrm{ft} \text { Depth }\end{array}$ & $\begin{array}{c}\text { Contiguous Stream } \\
\text { Width Greater Than } \\
0.4 \mathrm{ft} \text { Depth }\end{array}$ & $\begin{array}{l}\text { Percent Contiguous } \\
\text { Stream Width Greater } \\
\text { Than } 0.4 \mathrm{ft} \text { Depth }\end{array}$ \\
\hline 5 & 17.22 & 6.79 & 39.44 & 4.70 & 27.3 \\
\hline 7 & 17.30 & 7.81 & 45.16 & 5.13 & 29.7 \\
\hline 9.15 & 17.36 & 8.67 & 49.95 & 5.50 & 31.7 \\
\hline 11 & 17.40 & 9.30 & 53.42 & 5.77 & 33.2 \\
\hline 13 & 17.45 & 13.52 & 77.50 & 13.51 & 77.4 \\
\hline 15 & 17.48 & 13.74 & 78.56 & 13.70 & 78.3 \\
\hline 17 & 17.52 & 13.93 & 79.55 & 13.87 & 79.2 \\
\hline 19 & 17.55 & 14.12 & 80.44 & 14.03 & 80.0 \\
\hline 21 & 17.58 & 14.28 & 81.24 & 14.18 & 80.7 \\
\hline 23 & 17.60 & 14.44 & 82.00 & 14.32 & 81.3 \\
\hline 25 & 17.63 & 14.58 & 82.70 & 14.44 & 81.9 \\
\hline 27 & 17.65 & 15.42 & 87.33 & 15.26 & 86.4 \\
\hline 29 & 17.66 & 15.58 & 88.20 & 15.32 & 86.7 \\
\hline 30.8 & 17.67 & 15.71 & 88.93 & 15.37 & 87.0 \\
\hline 32 & 17.68 & 15.81 & 89.41 & 15.41 & 87.2 \\
\hline 34 & 17.69 & 15.95 & 90.18 & 15.47 & 87.5 \\
\hline 36 & 17.70 & 16.09 & 90.90 & 15.52 & 87.7 \\
\hline 38 & 17.71 & 16.22 & 91.59 & 15.57 & 88.0 \\
\hline 40 & 17.71 & 16.32 & 92.15 & 15.62 & 88.2 \\
\hline $\begin{array}{c}\text { Discharge } \\
\left(\mathrm{ft}^{3} / \mathrm{s}\right)\end{array}$ & $\begin{array}{c}\text { Stream width } \\
(\mathrm{ft})\end{array}$ & $\begin{array}{c}\text { Total Stream } \\
\text { Width Greater } \\
\text { Than } 0.6 \mathrm{ft} \text { Depth }\end{array}$ & $\begin{array}{l}\text { Percent Stream } \\
\text { Width Greater } \\
\text { Than } 0.6 \text { ft Depth }\end{array}$ & $\begin{array}{c}\text { Contiguous Stream } \\
\text { Width Greater Than } \\
\text { 0.6 ft Depth }\end{array}$ & $\begin{array}{l}\text { Percent Contiguous } \\
\text { Stream Width Greater } \\
\text { Than } \mathbf{0 . 6} \mathrm{ft} \text { Depth }\end{array}$ \\
\hline 5 & 17.22 & 1.98 & 11.50 & 1.98 & 11.5 \\
\hline 7 & 17.30 & 2.51 & 14.53 & 2.51 & 14.5 \\
\hline 9.15 & 17.36 & 2.96 & 17.07 & 2.96 & 17.1 \\
\hline 11 & 17.40 & 3.29 & 18.91 & 3.29 & 18.9 \\
\hline 13 & 17.45 & 3.55 & 20.36 & 3.55 & 20.4 \\
\hline 15 & 17.48 & 3.73 & 21.36 & 3.73 & 21.4 \\
\hline 17 & 17.52 & 3.90 & 22.28 & 3.90 & 22.3 \\
\hline 19 & 17.55 & 4.06 & 23.11 & 4.06 & 23.1 \\
\hline 21 & 17.58 & 4.19 & 23.86 & 4.19 & 23.9 \\
\hline 23 & 17.60 & 4.33 & 24.58 & 4.33 & 24.6 \\
\hline 25 & 17.63 & 4.45 & 25.23 & 4.45 & 25.2 \\
\hline 27 & 17.65 & 6.48 & 36.71 & 4.56 & 25.9 \\
\hline 29 & 17.66 & 6.81 & 38.53 & 4.70 & 26.6 \\
\hline 30.8 & 17.67 & 7.08 & 40.07 & 4.82 & 27.3 \\
\hline 32 & 17.68 & 7.26 & 41.08 & 4.90 & 27.7 \\
\hline 34 & 17.69 & 7.55 & 42.69 & 5.02 & 28.4 \\
\hline 36 & 17.70 & 7.82 & 44.21 & 5.14 & 29.0 \\
\hline 38 & 17.71 & 8.08 & 45.64 & 5.25 & 29.6 \\
\hline 40 & 17.71 & 8.29 & 46.83 & 5.34 & 30.2 \\
\hline
\end{tabular}


Table 2A. Passage criteria assessment for transect 2 (wide low slope), site PC2, upper Pole Creek, 2003 — Continued

\begin{tabular}{|c|c|c|c|c|c|}
\hline $\begin{array}{c}\text { Discharge } \\
\qquad\left(\mathrm{ft}^{3} / \mathrm{s}\right)\end{array}$ & $\begin{array}{c}\text { Stream width } \\
(\mathrm{ft})\end{array}$ & $\begin{array}{c}\text { Total Stream } \\
\text { Width Greater } \\
\text { Than } 0.8 \text { ft Depth }\end{array}$ & $\begin{array}{l}\text { Percent Stream } \\
\text { Width Greater } \\
\text { Than } 0.8 \text { ft Depth }\end{array}$ & $\begin{array}{c}\text { Contiguous Stream } \\
\text { Width Greater Than } \\
0.8 \mathrm{ft} \text { Depth }\end{array}$ & $\begin{array}{l}\text { Percent Contiguous } \\
\text { Stream Width Greater } \\
\text { Than } \mathbf{0 . 8} \mathrm{ft} \text { Depth }\end{array}$ \\
\hline 5 & 17.22 & 0.00 & 0.00 & 0.00 & 0.00 \\
\hline 7 & 17.30 & 0.00 & 0.00 & 0.00 & 0.00 \\
\hline 9.15 & 17.36 & 0.00 & 0.00 & 0.00 & 0.00 \\
\hline 11 & 17.40 & 0.00 & 0.00 & 0.00 & 0.00 \\
\hline 13 & 17.45 & 0.00 & 0.00 & 0.00 & 0.00 \\
\hline 15 & 17.48 & 0.00 & 0.00 & 0.00 & 0.00 \\
\hline 17 & 17.52 & 0.00 & 0.00 & 0.00 & 0.00 \\
\hline 19 & 17.55 & 0.00 & 0.00 & 0.00 & 0.00 \\
\hline 21 & 17.58 & 0.00 & 0.00 & 0.00 & 0.00 \\
\hline 23 & 17.60 & 0.00 & 0.00 & 0.00 & 0.00 \\
\hline 25 & 17.63 & 0.00 & 0.00 & 0.00 & 0.00 \\
\hline 27 & 17.65 & 1.82 & 10.29 & 1.82 & 10.29 \\
\hline 29 & 17.66 & 1.99 & 11.25 & 1.99 & 11.25 \\
\hline 30.8 & 17.67 & 2.13 & 12.05 & 2.13 & 12.05 \\
\hline 32 & 17.68 & 2.23 & 12.59 & 2.23 & 12.59 \\
\hline 34 & 17.69 & 2.38 & 13.44 & 2.38 & 13.44 \\
\hline 36 & 17.70 & 2.52 & 14.24 & 2.52 & 14.24 \\
\hline 38 & 17.71 & 2.65 & 14.99 & 2.65 & 14.99 \\
\hline 40 & 17.71 & 2.77 & 15.62 & 2.77 & 15.62 \\
\hline
\end{tabular}




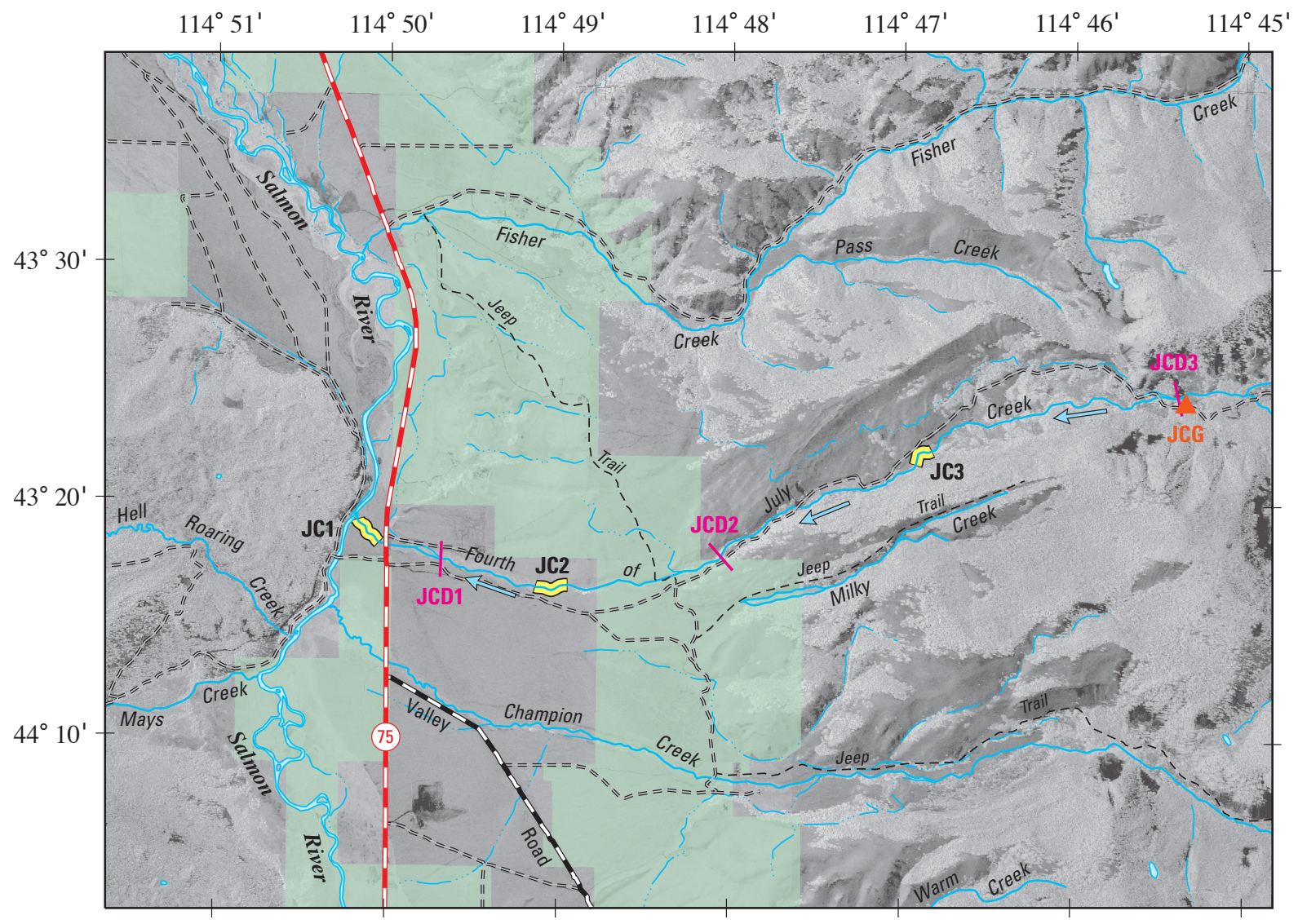

Base from U.S. Geological Survey digital data; 1998; 1:40,000,

Transverse Mercator projection; Factor at central meridian: 0.99960;

Longitude of central meridian: $-114^{\circ} 00^{\prime}$; Latitude of origin: $42^{\circ} 00^{\prime}$

False easting (meters): 500,000; False northing (meters): 100,000

Hydrography from U.S. Geological Survey; 1999; 1:24,000
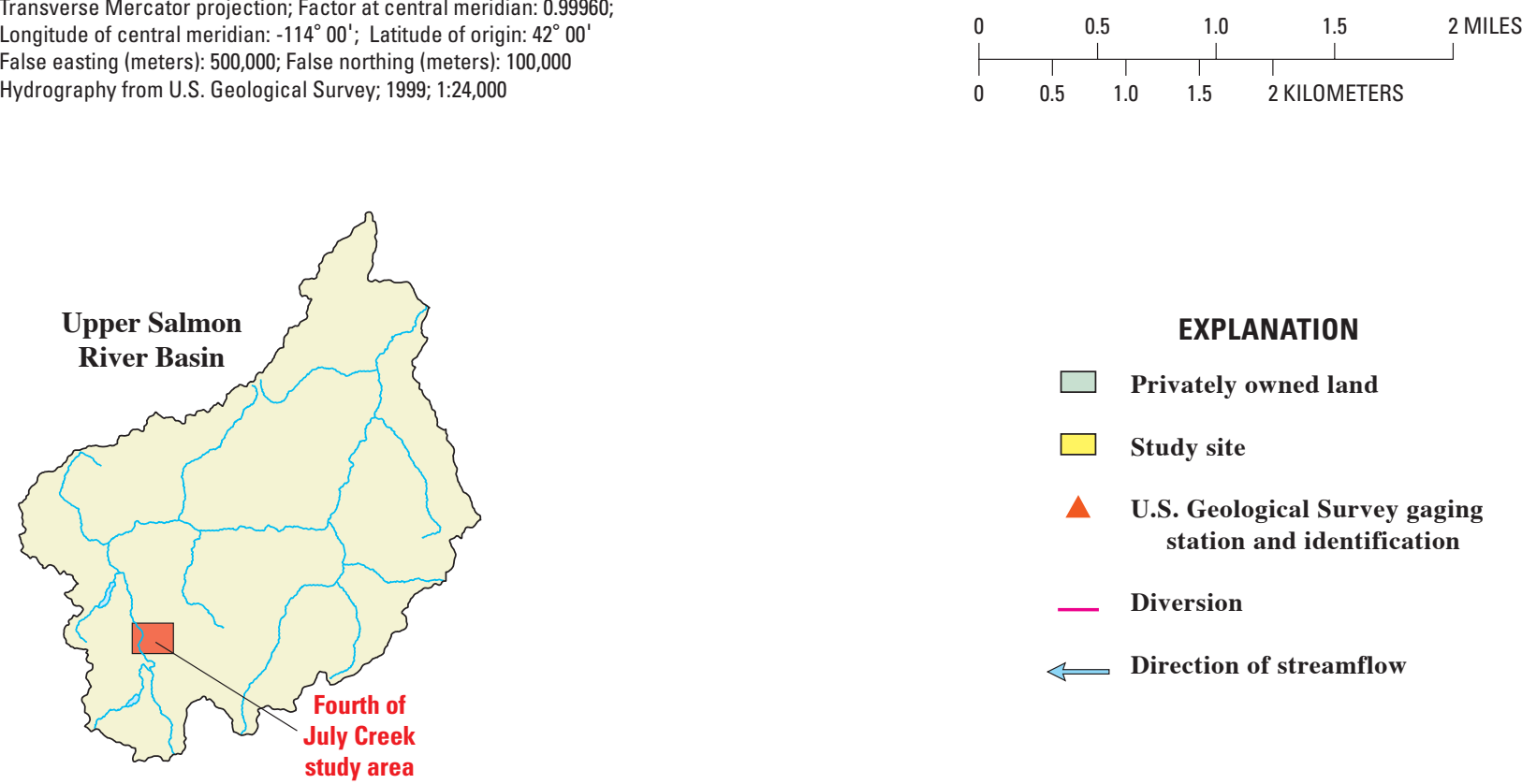

\section{EXPLANATION}

Privately owned land

Study site

$\triangle \quad$ U.S. Geological Survey gaging station and identification

- Diversion

$\Longleftarrow$ Direction of streamflow

Figure 8. Fourth of July Creek study sites, diversions, and gaging station locations, upper Salmon River Basin, Idaho, 2003 (Basin and site characteristics shown in table 1) 


\section{Fourth of July Creek (click here for abbreviations used in figures $10 \mathrm{~A}-38 \mathrm{~A}$ and tables $3 \mathrm{~A}-9 \mathrm{~A}$ )}

Fourth of July Creek is a westerly flowing tributary to the Salmon River and is located approximately $20 \mathrm{mi}$ downstream from the Salmon River headwaters (figure 1). Fourth of July Creek originates in the White Cloud Peaks on the east side of the Sawtooth Valley. The Fourth of July Creek Basin covers $18.1 \mathrm{mi}^{2}$, of which about 67 percent is forest. The basin has a mean elevation of about $8,730 \mathrm{ft}$ above sea level and receives an average of about $31 \mathrm{in.}$ of precipitation per year.

\section{Hydrology During 2003}

A short-term streamflow gaging station (13293350) was installed and operated on Fourth of July Creek during the period June 1 through October 6, 2003 (figure 8, JCG). The gage was located in a forested area, upstream from all active diversions, about $4.5 \mathrm{mi}$ upstream from the confluence with the Salmon River. Stage data were collected at 15-minute intervals and five instantaneous discharge measurements were completed. Stage-discharge relations from the instantaneous measurements were used to determine discharges at each 15- minute interval, resulting in a continuous record of streamflow. A plot of the continuous daily mean streamflow in Fourth of July Creek upstream from the diversions during WY03 is presented in figure 9, along with markers indicating the times when field data were collected at the study sites, which were located downstream.

Additional analyses were completed to relate streamflows in Fourth of July Creek during WY03 to long-term mean streamflows. The same techniques used to estimate long-term streamflows for Pole Creek also were used for Fourth of July

Creek. The July, August, and September daily mean discharge hydrograph for Fourth of July Creek upstream from diversions (13293350) for WY03 and the estimated long-term daily mean hydrograph are presented in figure 10. Also presented in figure 10 are estimated monthly streamflow exceedance statistics for the gaging station location based on regional regression equations developed by Hortness and Berenbrock (2001). Again, the median estimate gives an indication of long-term average streamflow conditions, and the other estimates provide an indication of the probable variation in streamflows at this location.

The 80-, 50-, and 20-percent monthly exceedance discharge values estimated on the basis of WY03 daily mean discharge values and estimated long-term daily mean

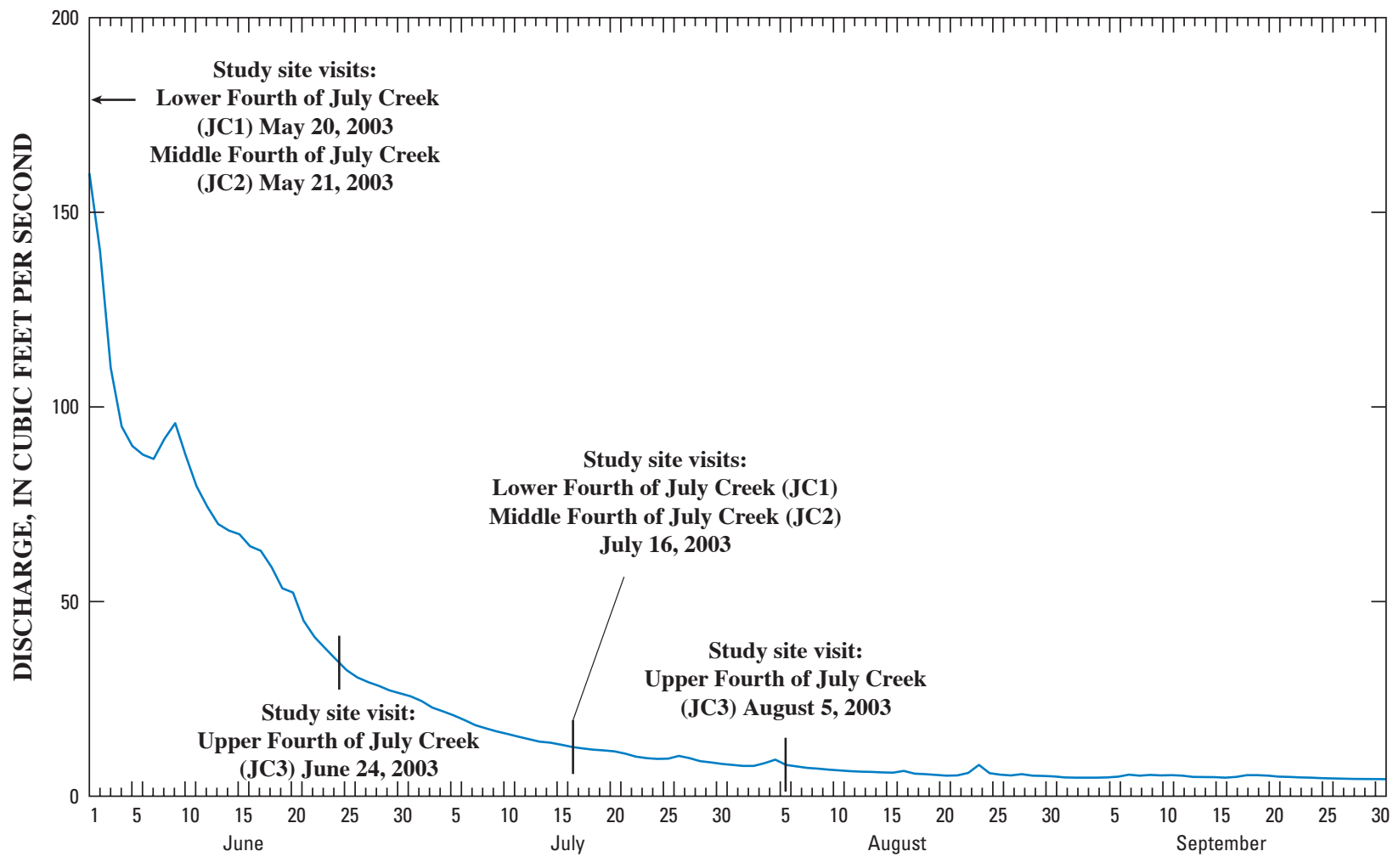

MONTH

Figure 9. Daily mean discharge at Fourth of July Creek upstream from diversions near Obsidian (13293350), upper Salmon River Basin, Idaho, June 1 through September 30, 2003 


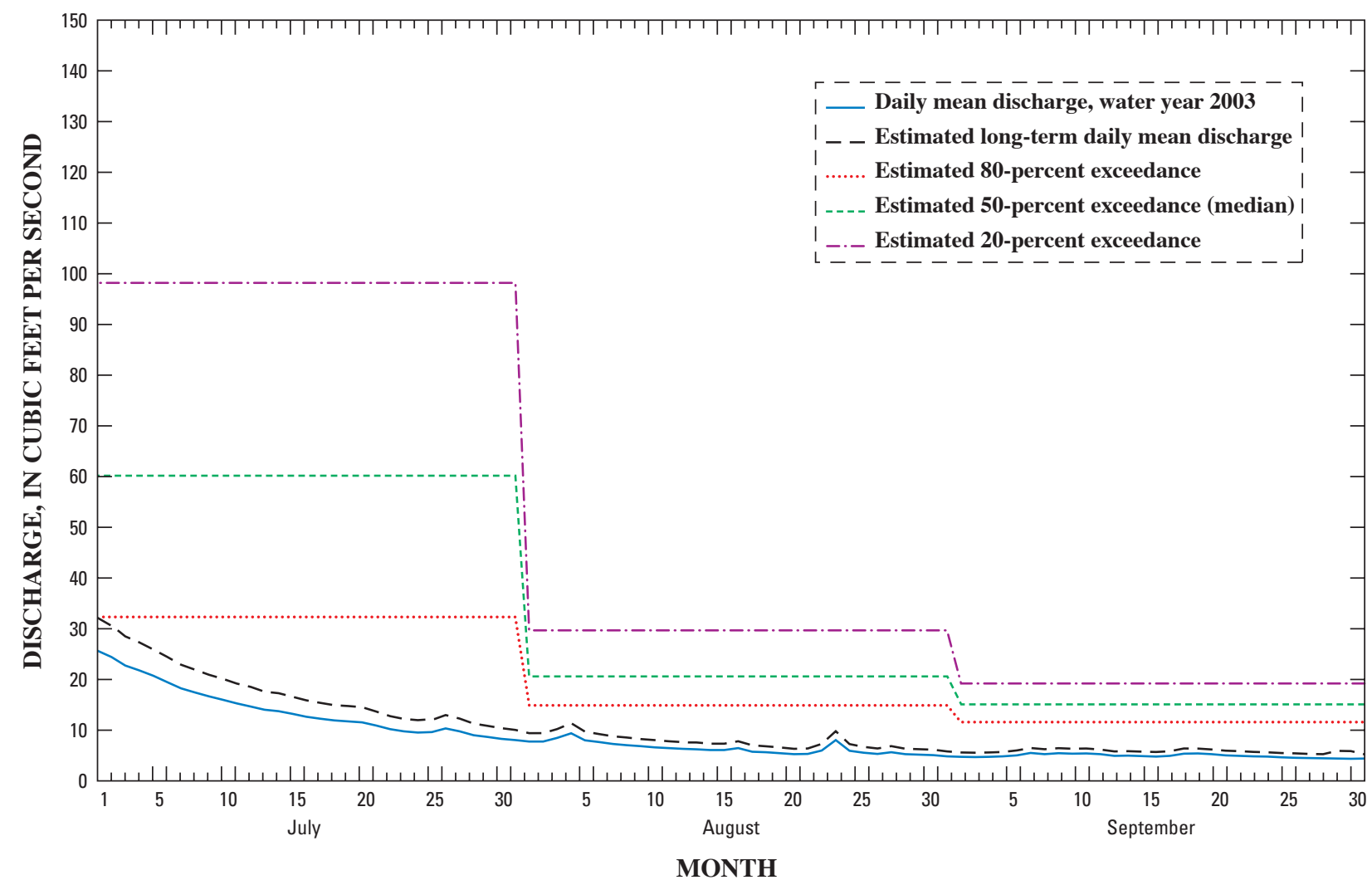

Figure 10. Daily mean discharge for water year 2003, estimated long-term daily mean discharge, and estimated $80-, 50-$, and 20-percent exceedance statistics for Fourth of July Creek upstream from diversions near Obsidian (13293350), upper Salmon River Basin, Idaho, July 1 through September 30

discharge values at the Fourth of July Creek gaging station (13293350) are presented in table 5. Exceedance estimates, along with the confidence limits, derived from the regional regression equations (Hortness and Berenbrock, 2001) for this location also are presented in the table. Comparison between the estimated long-term daily mean discharge values and values calculated on the basis of the regression equations can provide some insight as to the applicability of the regression equations for Fourth of July Creek. As was apparent in figure 10 , the regression equation estimates tend to be higher than the estimated long-term values, indicating that the equations, to some degree, could overestimate streamflow conditions in Fourth of July Creek.

In addition to the continuous-record data, instantaneous discharge was measured at the mouth of Fourth of July Creek (13293400) (figure 8). Although seepage analyses were not within the scope of this project, these instantaneous measurements provide some indication of the amount of streamflow lost to ground water and the amount being diverted at specific times during the study period. A summary of all discharge measured in Fourth of July Creek during the study period is presented in table 6 .

\section{Habitat Modeling and Passage Results}

Upper Fourth of July Creek (JC3) discharges required for maximum WUA ranged from 9 to $51 \mathrm{ft}^{3} / \mathrm{s}, 9$ to $39 \mathrm{ft}^{3} / \mathrm{s}$, and 9 to $39 \mathrm{ft}^{3} / \mathrm{s}$ for bull trout, chinook salmon, and steelhead trout life stages, respectively (table 7). Pool habitat made up only about 1 percent of the stream segment surveyed, indicating this stream may have limited juvenile rearing habitat. Discharges required for passage over shallow riffle habitat were both $15 \mathrm{ft} / 3$ s for the depth criterion of $0.6 \mathrm{ft}$ over 25 percent of the total channel width and over 10 percent of the contiguous channel width (see transect 5 photo at http:/lid.water. usgs.gov/projects/salmon_streamflow). For more information summarizing the results of this study site, see the appendices, figure $10 \mathrm{~A}$, figure $11 \mathrm{~A}$, figure $12 \mathrm{~A}$, figure $13 \mathrm{~A}$, figure $14 \mathrm{~A}$, figure $15 \mathrm{~A}$, figure $16 \mathrm{~A}$, figure $17 \mathrm{~A}$, figure $18 \mathrm{~A}$, and table $3 \mathrm{~A}$ and table $4 \mathrm{~A}$.

Fourth of July Creek no longer sustains runs of anadromous fish because the lower 2 mi historically have been dewatered during the irrigation season (Scott and others, 1981). However, it remains an important stream for bull trout. Streamflow is most important for this species during the month of August when they would be migrating out of the Salmon River into tributary streams to spawn (Munther, 1974). 
Table 5. Calculated and estimated 80-, 50-, and 20-percent monthly exceedance discharge values for Fourth of July Creek upstream from diversions near Obsidian (13293350), upper Salmon River Basin, Idaho, 2003

$[\mathrm{Q}$, discharge; values presented in cubic feet per second]

\begin{tabular}{|c|c|c|c|c|c|c|c|c|c|c|}
\hline & & \multicolumn{3}{|c|}{ July } & \multicolumn{3}{|c|}{ August } & \multicolumn{3}{|c|}{ September } \\
\hline & & 0.80 & 0.50 & 0.20 & 0.80 & 0.50 & 0.20 & 0.80 & 0.50 & 0.20 \\
\hline & Water year 2003 & 9.76 & 12.6 & 18.3 & 5.32 & 6.08 & 7.65 & 4.64 & 4.89 & 5.30 \\
\hline \multirow{2}{*}{ 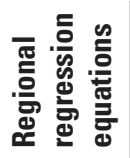 } & Upper confidence limit & 49.9 & 87.1 & 137.0 & 25.4 & 32.6 & 44.5 & 20.3 & 21.9 & 27.1 \\
\hline & Estimate & 32.3 & 60.2 & 98.2 & 14.9 & 20.6 & 29.7 & 11.6 & 15.1 & 19.2 \\
\hline
\end{tabular}

${ }^{1}$ Estimate based on comparisons between water year 2003 and long-term monthly mean discharges at Valley Creek at Stanley (13295000).

Summer (July through September) discharges for JC3 were estimated on the basis of regression equations and are listed in table 7. Median discharge (Q.50) estimates for the months of July, August, and September are 59.8, 20.7, and $15.3 \mathrm{ft}^{3} / \mathrm{s}$, respectively. The mean annual discharge estimate is $51.4 \mathrm{ft} / \mathrm{s}$. As indicated earlier, on the basis of WY03 data, the regression equations might, to some degree, overestimate streamflow statistics for Fourth of July Creek. Adjustments to these estimates would be possible on the basis of comparison information provided in figure 10 and table 5. However, any adjustments would be somewhat crude, because they would be based on only 1 partial year of streamflow data.

Middle Fourth of July Creek (JC2) discharges required for maximum WUA ranged from 12 to $18 \mathrm{ft}^{3} / \mathrm{s}, 9$ to $27 \mathrm{ft}^{3} / \mathrm{s}$, and 9 to $27 \mathrm{ft} 3 / \mathrm{s}$ for bull trout, chinook salmon, and steelhead trout life stages, respectively (table 7). Pool habitat made up about 5 percent of the stream segment surveyed, indicating this stream may have limited juvenile rearing habitat. Discharges required for passage over shallow riffle habitat ranged from 9 to $11 \mathrm{ft}^{3} / \mathrm{s}$ for the depth criterion of $0.6 \mathrm{ft}$ over 25 percent of the total channel width and over 10 percent of the contiguous channel width, respectively (see transect 2 photo at http://id.water.usgs.gov/projects/salmon streamflow). For more information summarizing the results of this study site, see the appendices, figure $19 \mathrm{~A}$, figure $20 \mathrm{~A}$, figure $21 \mathrm{~A}$, figure $22 \mathrm{~A}$, figure $23 \mathrm{~A}$, figure $24 \mathrm{~A}$, figure $25 \mathrm{~A}$, figures $26 \mathrm{~A}$, figure $27 \mathrm{~A}$, and table $5 \mathrm{~A}$ and table $6 \mathrm{~A}$.

Median discharge (Q.50) estimates, based on regression equations, for the months of July, August, and September are $59.9,20.8$, and $15.6 \mathrm{ft} / 3 \mathrm{~s}$, respectively. The mean annual discharge estimate is $52.8 \mathrm{ft}^{3} / \mathrm{s}$ (table 7).

Lower Fourth of July Creek (JC1) discharges required for maximum WUA ranged from 12 to $18 \mathrm{ft}^{3} / \mathrm{s}, 7$ to $30 \mathrm{ft}^{3} / \mathrm{s}$, and 12 to $30 \mathrm{ft}^{3} / \mathrm{s}$ for bull trout, chinook salmon, and steelhead trout life stages, respectively. Pool habitat made up about 5 percent of the stream segment surveyed, indicating this stream may have limited juvenile rearing habitat. Discharges required for passage over two shallow riffle habitats near the mouth of the stream ranged from 18 to $5 \mathrm{ft}^{3} / \mathrm{s}$ and 27 to $12 \mathrm{ft}^{3} / \mathrm{s}$ for the depth criterion of $0.6 \mathrm{ft}$ over 25 percent of the total channel width and over 10 percent of the contiguous channel width, respectively (see transects 1 and 5 photos at http://id.water. usgs.gov/projects/salmon_streamflow). For more information summarizing the results of this study site, see the appendices, figure $28 \mathrm{~A}$, figure $29 \mathrm{~A}$, figure $30 \mathrm{~A}$, figure $31 \mathrm{~A}$, figure $32 \mathrm{~A}$, figure $33 \mathrm{~A}$, figure $34 \mathrm{~A}$, figure $35 \mathrm{~A}$, figure $36 \mathrm{~A}$, figure $37 \mathrm{~A}$, and figure $38 \mathrm{~A}$ and table $7 \mathrm{~A}$, table $8 \mathrm{~A}$, and table $9 \mathrm{~A}$.

Munther (1974), using a passage criterion similar to that used in this study ( $0.6 \mathrm{ft}$ water depth over 25 percent of the total channel width), estimated that a discharge of $15 \mathrm{ft}^{3} / \mathrm{s}$ would provide passage for bull trout downstream from all diversions.

Table 6. Miscellaneous discharge measurements collected on Fourth of July Creek, upper Salmon River Basin, Idaho, 2002-03

[Basin and site characteristics shown in table 1; locations shown in figure 8; JCG, Fourth of July Creek at U.S. Geological Survey gage; JC3, upper Fourth of July Creek; JC2, middle Fourth of July Creek; JC1, lower Fourth of July Creek; values presented in cubic feet per second; - , no data available]

\begin{tabular}{c|c|c|c|c}
\hline \multicolumn{1}{c|}{ Date } & JCG $^{1}$ & JC3 & JC2 & JC1 \\
\hline $10 / 16 / 02$ & - & - & - & 7.34 \\
\hline $11 / 20 / 02$ & - & - & - & 7.24 \\
\hline $5 / 20 / 03$ & - & - & - & 9.60 \\
\hline $5 / 21 / 03$ & - & - & 12.4 & - \\
\hline $6 / 24 / 03$ & $\underline{35.2}$ & 32.7 & - & - \\
\hline $7 / 10 / 03$ & 16.9 & - & - & 7.97 \\
\hline $7 / 16 / 03$ & $\underline{12.6}$ & - & 9.30 & 4.80 \\
\hline $7 / 31 / 03$ & $\underline{8.0}$ & - & - & - \\
\hline $8 / 5 / 03$ & $\underline{8.0}$ & 9.32 & - & - \\
\hline $8 / 27 / 03$ & 6.04 & - & - & 3.15 \\
\hline $9 / 29 / 03$ & $\underline{4.4}$ & - & - & - \\
\hline $10 / 7 / 03$ & - & - & - & 2.39 \\
\hline
\end{tabular}

${ }^{1}$ Daily mean discharge values are underlined. 
Table 7. Habitat and discharge measurements for upper (JC3), middle (JC2), and lower (JC1) Fourth of July Creek, upper Salmon River Basin, Idaho, 2003

[WUA, weighted usable area; $\mathrm{ft}^{3} / \mathrm{s}$, cubic feet per second. WUA maximum discharge estimates were based on Physical Habitat Simulation Model output; Q.xx, daily discharge exceeded $\mathrm{xx}$ percent of the time during the specified month, in $\mathrm{ft}^{3} / \mathrm{s}$; $\mathrm{Qa}$, mean annual discharge, in $\mathrm{ft}^{3} / \mathrm{s}$; ND, not determined]

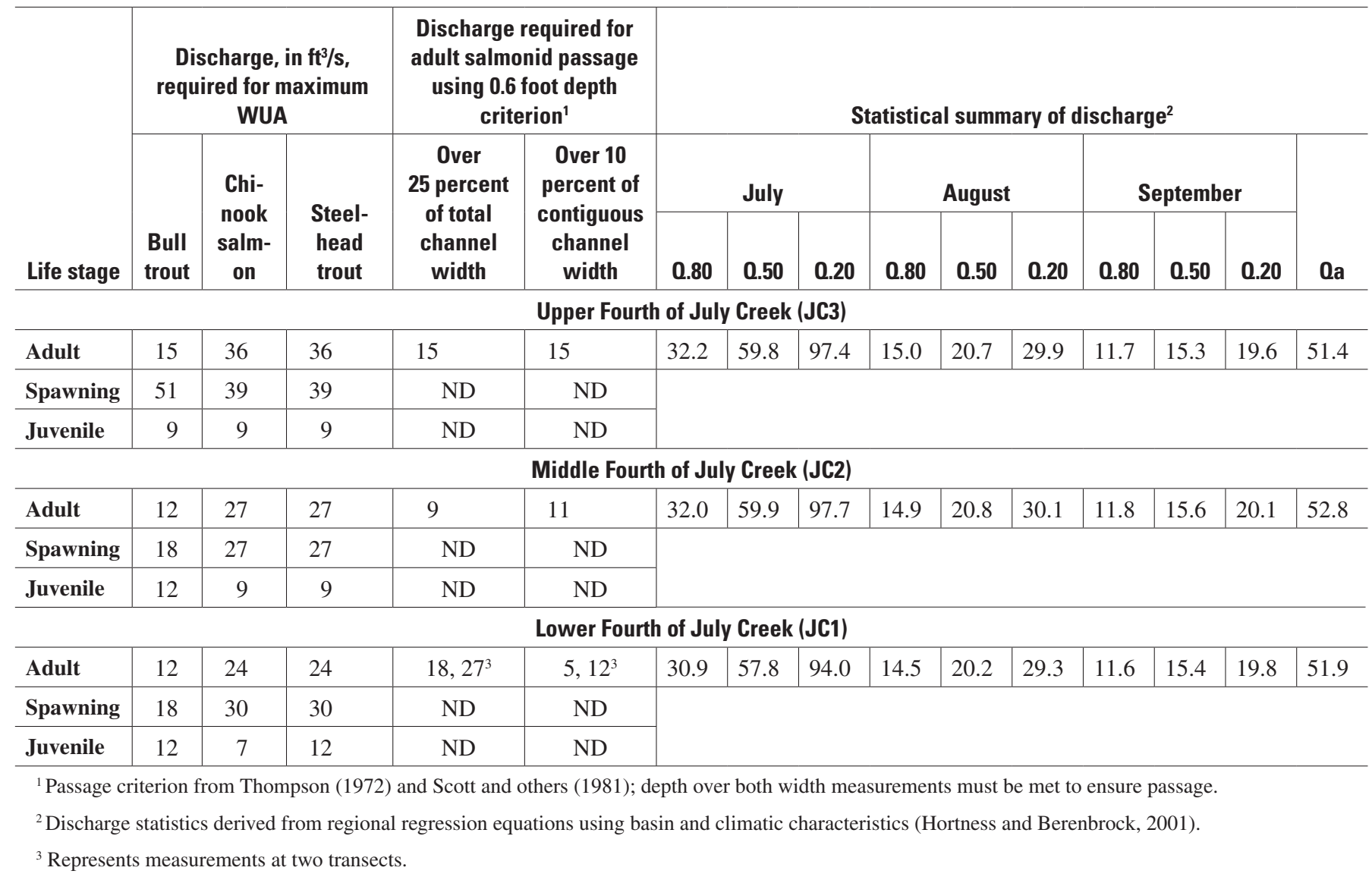

Median discharge (Q.50) estimates, based on regression equations, for the months of July, August, and September are $57.8,20.2$, and $15.4 \mathrm{ft}^{3} / \mathrm{s}$, respectively. The mean annual discharge estimate is $51.9 \mathrm{ft} \%$ s (table 7).

\section{Stream Temperature Results}

Four data loggers were deployed in Fourth of July Creek (figure 8). One data logger was deployed in upper Fourth of July Creek near the USGS short-term gaging station (JCG) upstream from all diversions. Another data logger was deployed at PHABSIM study site JC3 downstream from the upper diversion (JCD3). A third data logger was deployed in middle Fourth of July Creek at the PHABSIM study site JC2 downstream from the middle diversion (JCD2). The last data logger was deployed in lower Fourth of July Creek at the PHABSIM study site JC1 near the mouth of Fourth of July Creek downstream from the lowest diversion (JCD1). All data loggers were deployed in late June and retrieved in late September. After the data were downloaded, June 25 through
September 28 (96 days) was selected as the period of record for calculating stream temperature metrics.

Analysis of the stream temperature metrics for Fourth of July Creek showed that temperatures were variable between JCG and JC1; a slight cooling trend between JCG and JC3, then a gradual warming trend downstream from JC3 to JC1 were noted (figure 11). The cooling trend noted in upper Fourth of July Creek between JCG and JC3 is possibly due to the dense riparian and overstory shading and the influx of cool ground water, and the warming trend in lower Fourth of July Creek from JC3 to JC1 most likely is due to a combination of factors, including the natural heating from increased exposure once the stream leaves the forested highlands and enters the valley floor and the diversion of streamflow for irrigation.

In 2003, the maximum difference in MDAT on any given day between $\mathrm{JC} 3$ and $\mathrm{JC} 1$ was $4.5^{\circ} \mathrm{C}$; maximum difference in MDMT was $8.5^{\circ} \mathrm{C}$. Large increases in water temperature in the lower end of Fourth of July Creek are not uncommon. In 2001, the USFS measured stream temperature increases of about $10^{\circ} \mathrm{C}$ over about $1 \mathrm{mi}$, between the Forest Service 


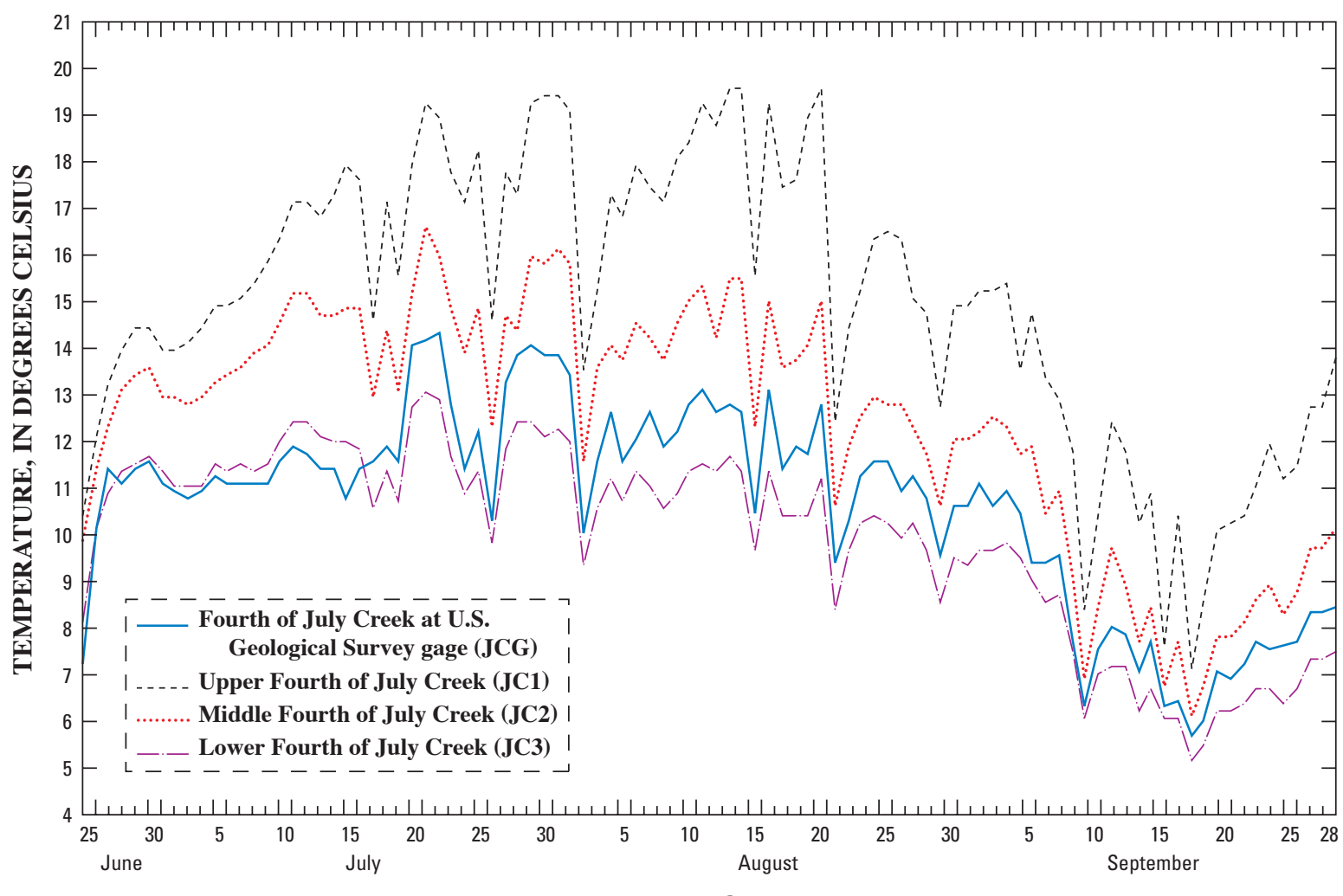

MONTH

Figure 11. Maximum daily water temperature for period June 25 through September 28, 2003, at Fourth of July Creek, upper Salmon River Basin, Idaho

boundary and the mouth of Fourth of July Creek (M. Moulton, U.S. Forest Service, written commun., 2003). No concurrent discharge measurements were made to evaluate any streamflow-temperature relation.

Estimating the effect of diversions on stream temperature in Fourth of July Creek was not completed in 2003, owing to the lack of adequate streamflow and diversion discharge data as required by the SSTEMP model. Application of SSTEMP in future years will require a synoptic quantification of streamflow and diversion discharge at critical areas throughout the stream segment, including instream discharge measurements upstream from all diversions, in each diversion, and downstream from all diversions.

Results of the individual metric calculations showed that the MDMT ranged from $14.4^{\circ} \mathrm{C}$ at JCG to $19.6^{\circ} \mathrm{C}$ at $\mathrm{JC} 1$. The MDMT at all sites was below the $21.0^{\circ} \mathrm{C}$ threshold that, according to Poole and others (2001), can create a thermal barrier that would block adult chinook salmon from migrating to their spawning grounds. The MDMT exceeded $18.0^{\circ} \mathrm{C}$ in July and August at JC1, indicating bull trout passage may have been blocked into Fourth of July Creek from the Salmon River as a result of high temperatures (J. Dunham, U.S. Forest Service, written commun., 2004). No stream temperatures in Fourth of July Creek exceeded the IDEQ $19.0^{\circ} \mathrm{C}$ MDAT and $22.0^{\circ} \mathrm{C}$ MDMT criteria for the protection of coldwater biota during the period of record. A summary of the individual temperature metrics for all study sites can be accessed at http://id.water.usgs.gov/projects/salmon_streamflow. 


\section{Fourth of July Creek Appendix Abbreviations}

Contiguous, continuous width with equal or greater water depth

Discharge, in $\mathrm{ft}^{3} / \mathrm{s}$

$\mathrm{ft}$, feet

$\mathrm{ft}^{2}$, square feet

$\mathrm{ft}^{3} / \mathrm{s}$, cubic feet per second

JC1, site number (see table 1)

RM1, local reference mark

Stream width, in $\mathrm{ft}$

T1, transect number

Total Area, study site area, in $\mathrm{ft}^{2}$

WUA, weighted usable area, in $\mathrm{ft}^{2}$ per $1,000 \mathrm{ft}$ of stream 


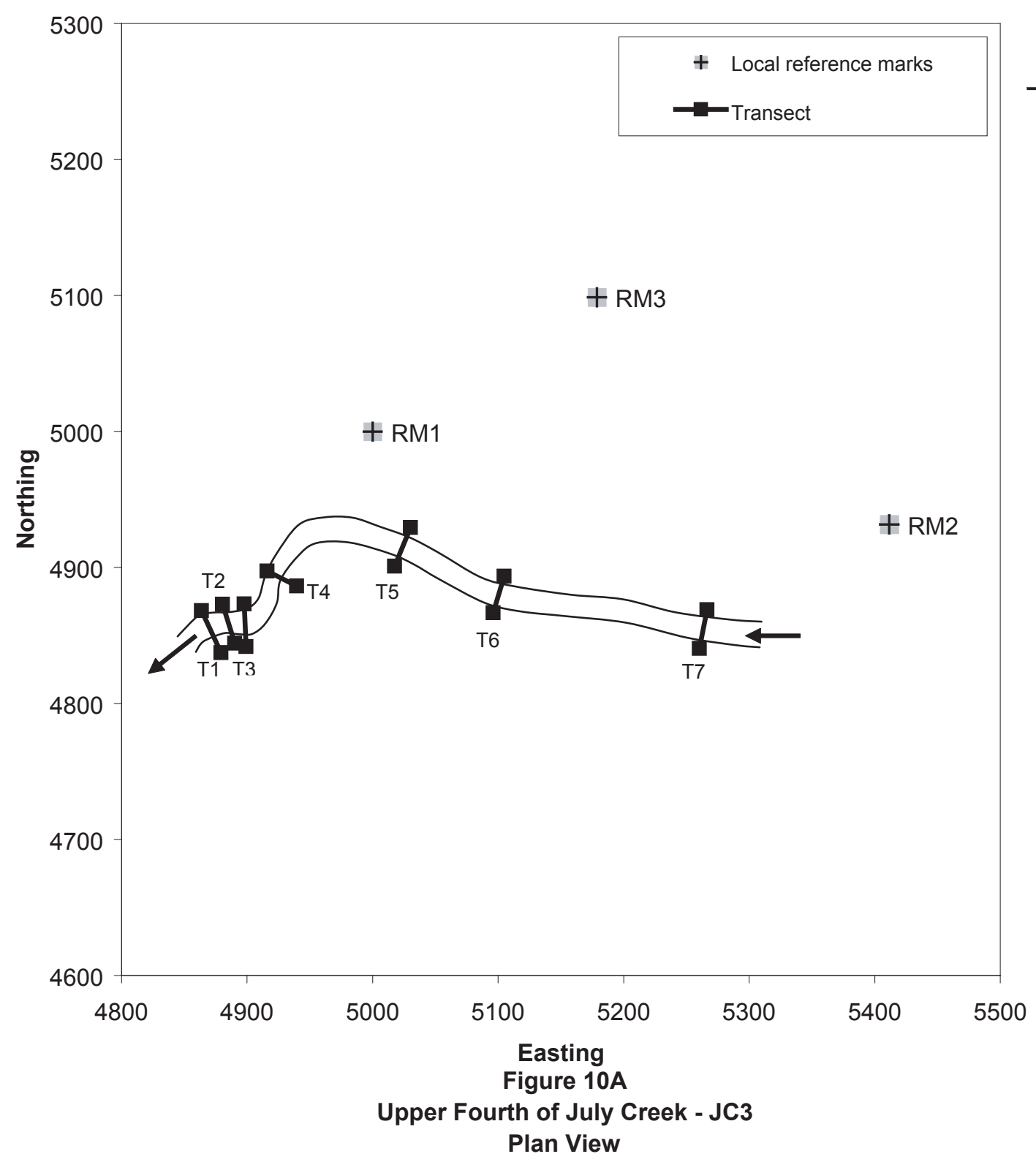

Iransect Endpoint Coordinates (NAD 83)

\begin{tabular}{ccc} 
Point & Latitude & Longitude \\
\hline LB T1 & $114^{\circ} 46^{\prime} 54.87^{\prime \prime} \mathrm{W}$ & $44^{\circ} 2^{\prime} 13.00^{\prime \prime} \mathrm{N}$ \\
RB T1 & $114^{\circ} 46^{\prime} 54.61^{\prime \prime} \mathrm{W}$ & $44^{\circ} 2^{\prime} 12.71 " \mathrm{~N}$ \\
LB T2 & $114^{\circ} 46^{\prime} 54.65^{\prime \prime} \mathrm{W}$ & $44^{\circ} 22^{\prime} 13.06^{\prime \prime} \mathrm{N}$ \\
RB T2 & $114^{\circ} 46^{\prime} 54.47^{\prime \prime} \mathrm{W}$ & $44^{\circ} 2^{\prime} 12.79^{\prime \prime} \mathrm{N}$ \\
LB T3 & $114^{\circ} 46^{\prime} 54.41^{\prime \prime} \mathrm{W}$ & $44^{\circ} 2^{\prime} 13.08^{\prime \prime} \mathrm{N}$ \\
RB T3 & $114^{\circ} 46^{\prime} 54.35^{\prime \prime} \mathrm{W}$ & $44^{\circ} 2^{\prime} 12.78^{\prime \prime} \mathrm{N}$ \\
LB T4 & $114^{\circ} 46^{\prime} 54.20^{\prime \prime} \mathrm{W}$ & $44^{\circ} 2^{\prime} 13.34^{\prime \prime} \mathrm{N}$ \\
RB T4 & $114^{\circ} 46^{\prime} 53.86^{\prime \prime} \mathrm{W}$ & $44^{\circ} 2^{\prime} 13.26^{\prime \prime} \mathrm{N}$ \\
LB T5 & $114^{\circ} 46^{\prime} 52.69^{\prime \prime} \mathrm{W}$ & $44^{\circ} 2^{\prime} 13.77^{\prime \prime} \mathrm{N}$ \\
RB T5 & $114^{\circ} 46^{\prime} 52.82^{\prime \prime} \mathrm{W}$ & $44^{\circ} 2^{\prime} 13.48^{\prime \prime} \mathrm{N}$ \\
LB T6 & $114^{\circ} 46^{\prime} 51.62^{\prime \prime} \mathrm{W}$ & $44^{\circ} 2^{\prime} 13.50^{\prime \prime} \mathrm{N}$ \\
RB T6 & $114^{\circ} 46^{\prime} 51.70^{\prime \prime} \mathrm{W}$ & $44^{\circ} 2^{\prime} 13.23^{\prime \prime} \mathrm{N}$ \\
LB T7 & $114^{\circ} 46^{\prime} 49.39^{\prime \prime} \mathrm{W}$ & $44^{\circ} 2^{\prime} 13.43^{\prime \prime} \mathrm{N}$ \\
RB T7 & $114^{\circ} 46^{\prime} 49.43^{\prime \prime} \mathrm{W}$ & $44^{\circ} 22^{\prime} 13.15^{\prime \prime} \mathrm{N}$
\end{tabular}

For reference only; stream schematic not to scale. 
Figure 11A

Upper Fourth of July Creek - JC:

Bull Trout WUA

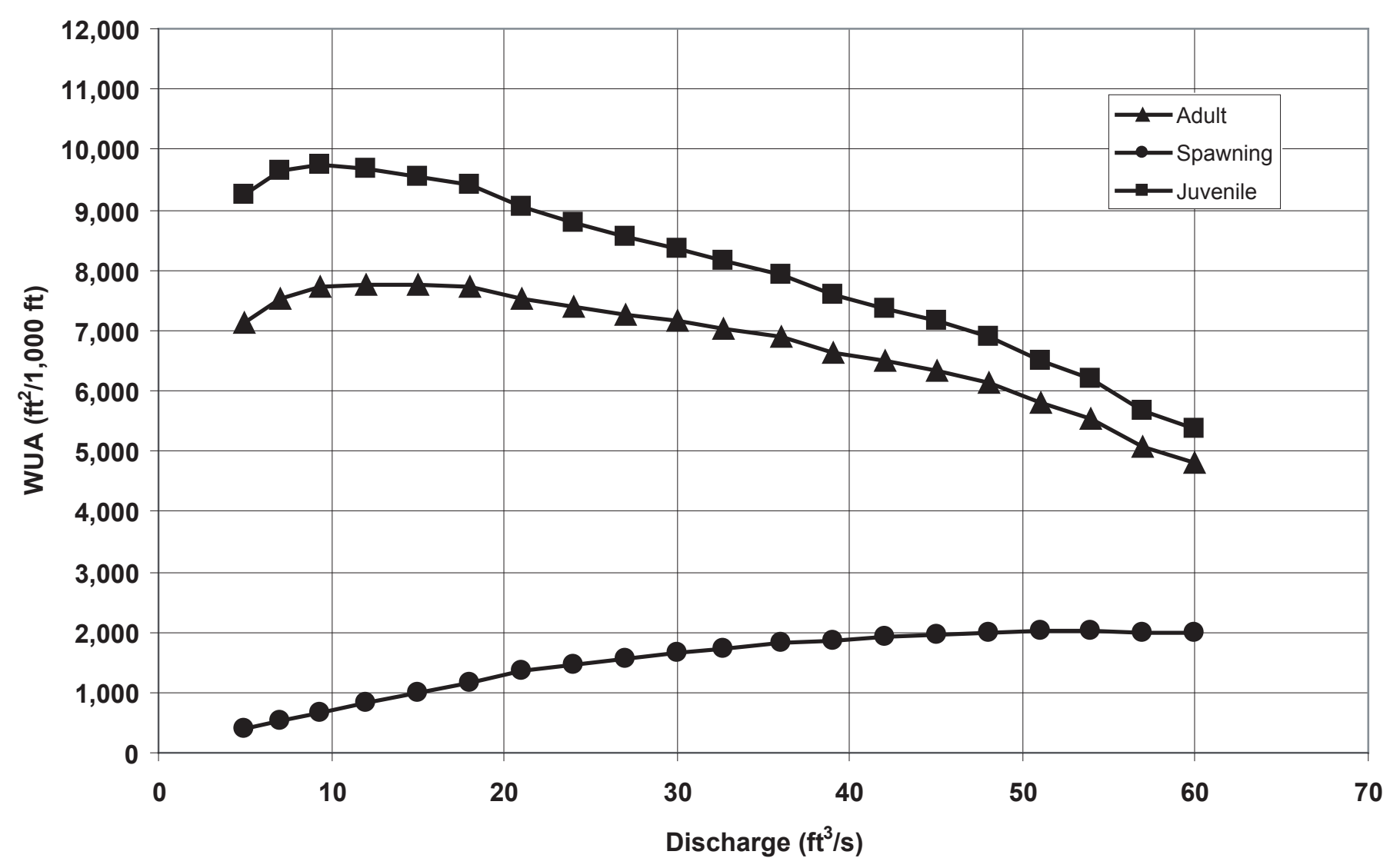


Figure 12A

Upper Fourth of July Creek - JC3

Bull Trout WUA Normalized

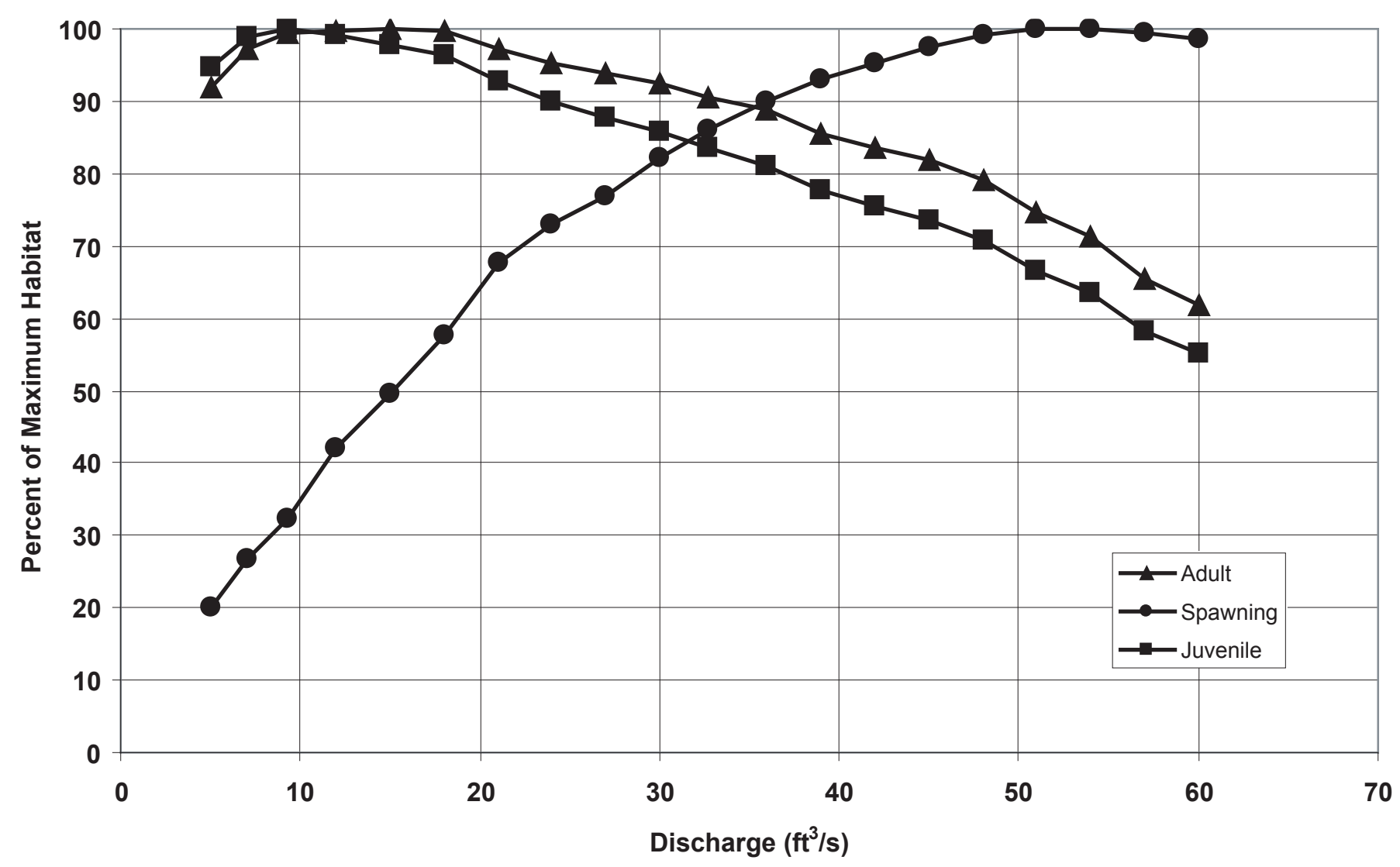


Figure 13A

Upper Fourth of July Creek - JC3

Chinook Salmon WUA

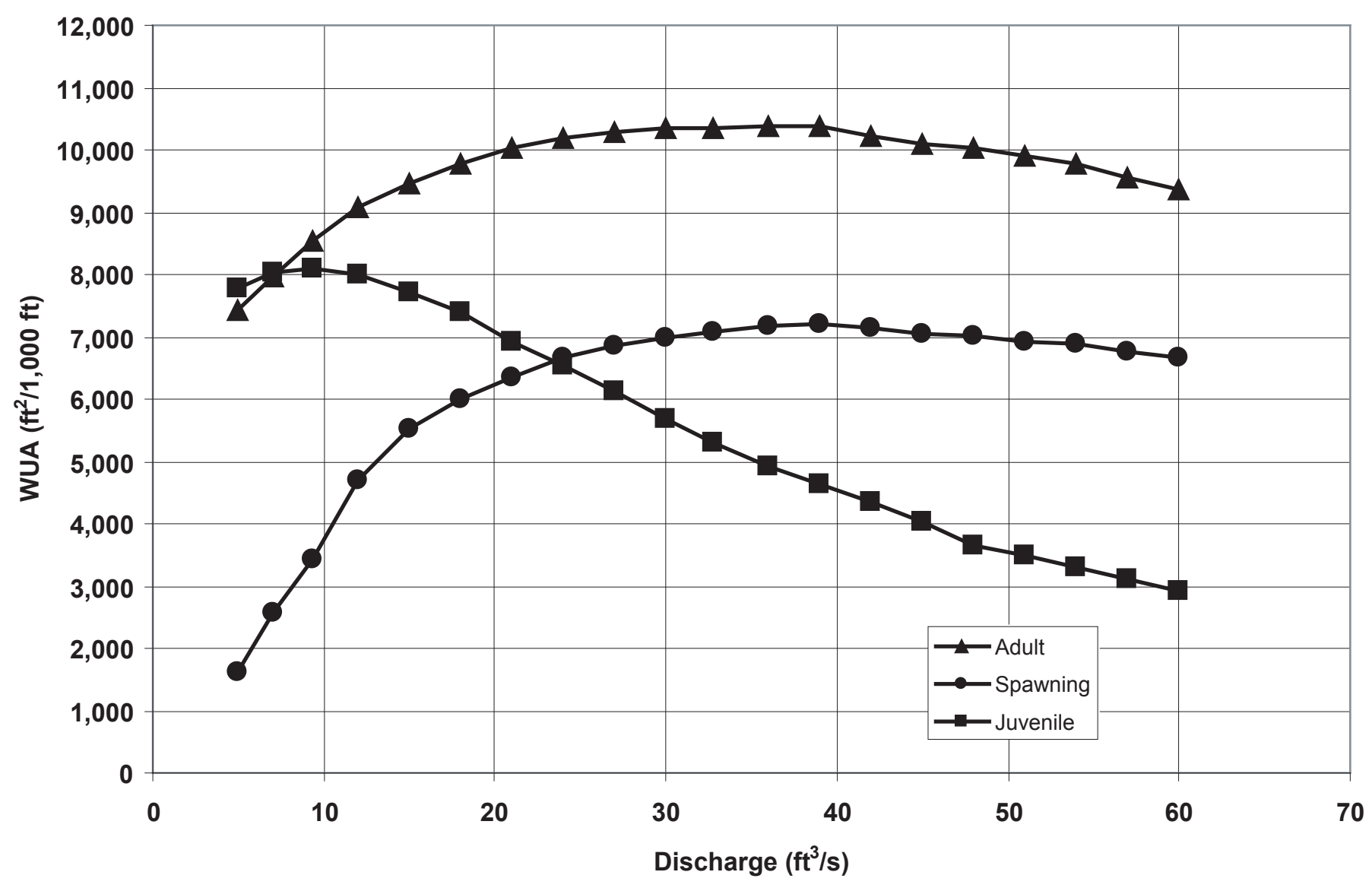


Figure 14A

Upper Fourth of July Creek - JC3

Chinook Salmon WUA Normalized

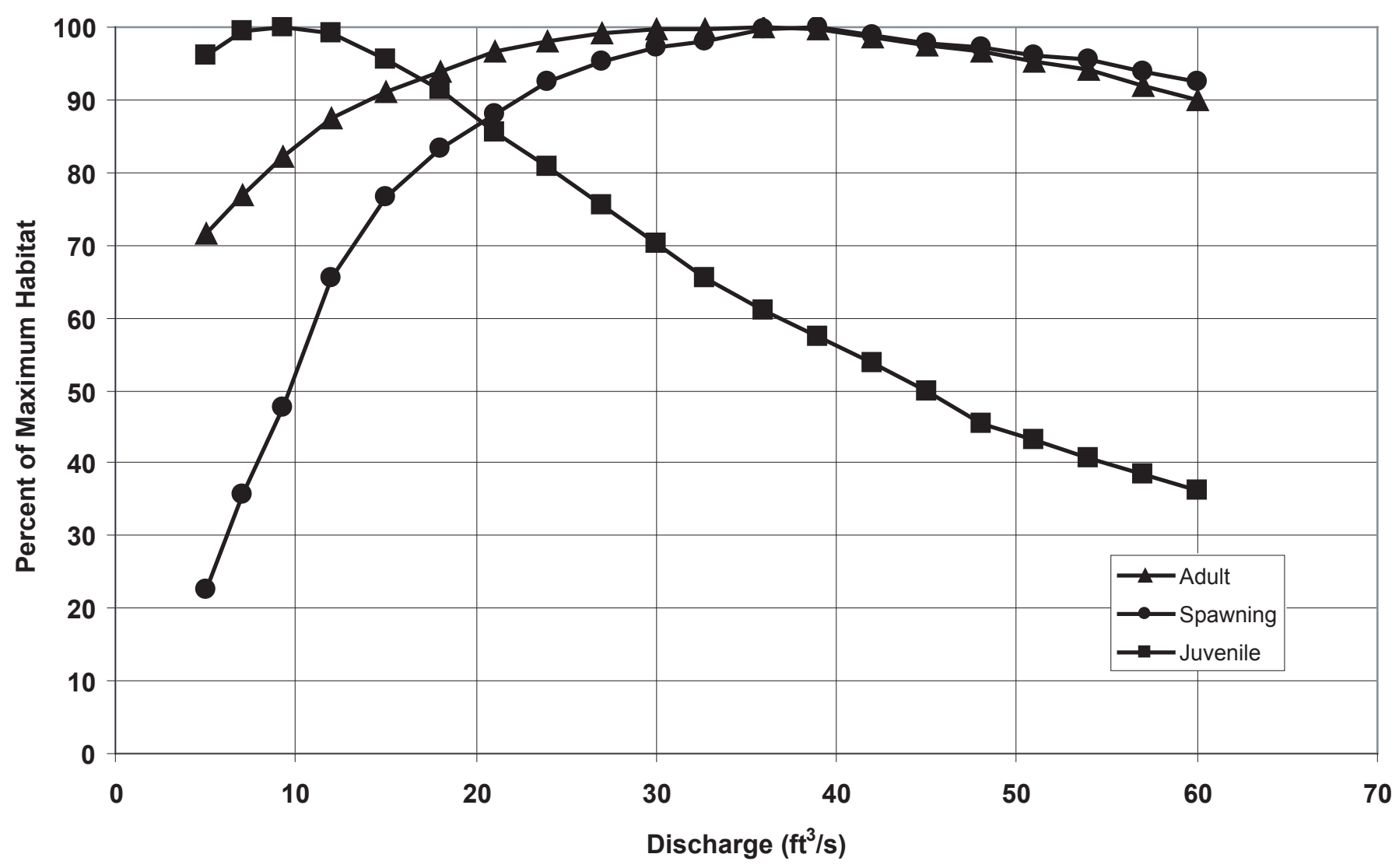


Figure 15A

Upper Fourth of July Creek - JC3

Steelhead WUA

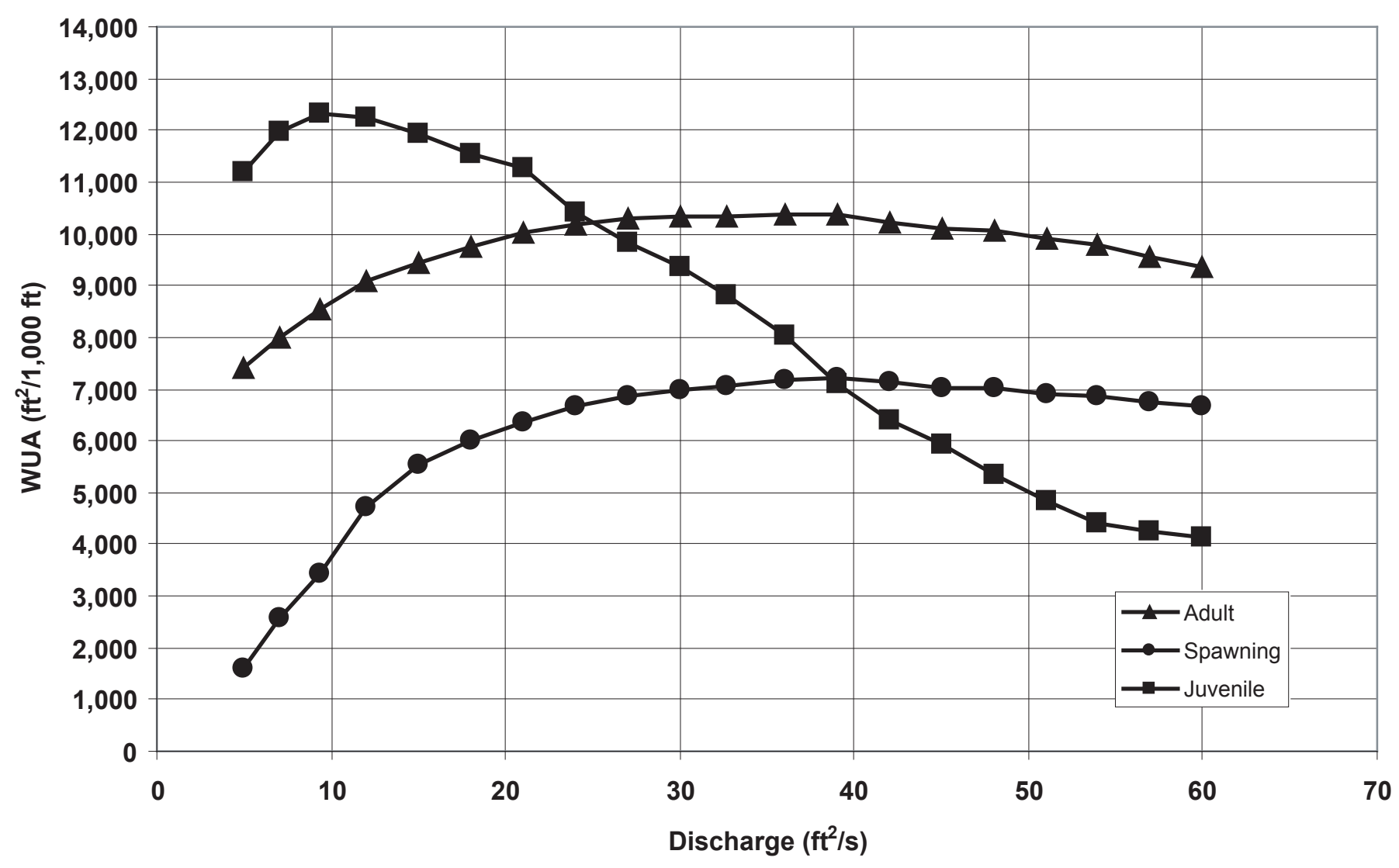


Figure 16A

Upper Fourth of July Creek - JC3

Steelhead WUA Normalized

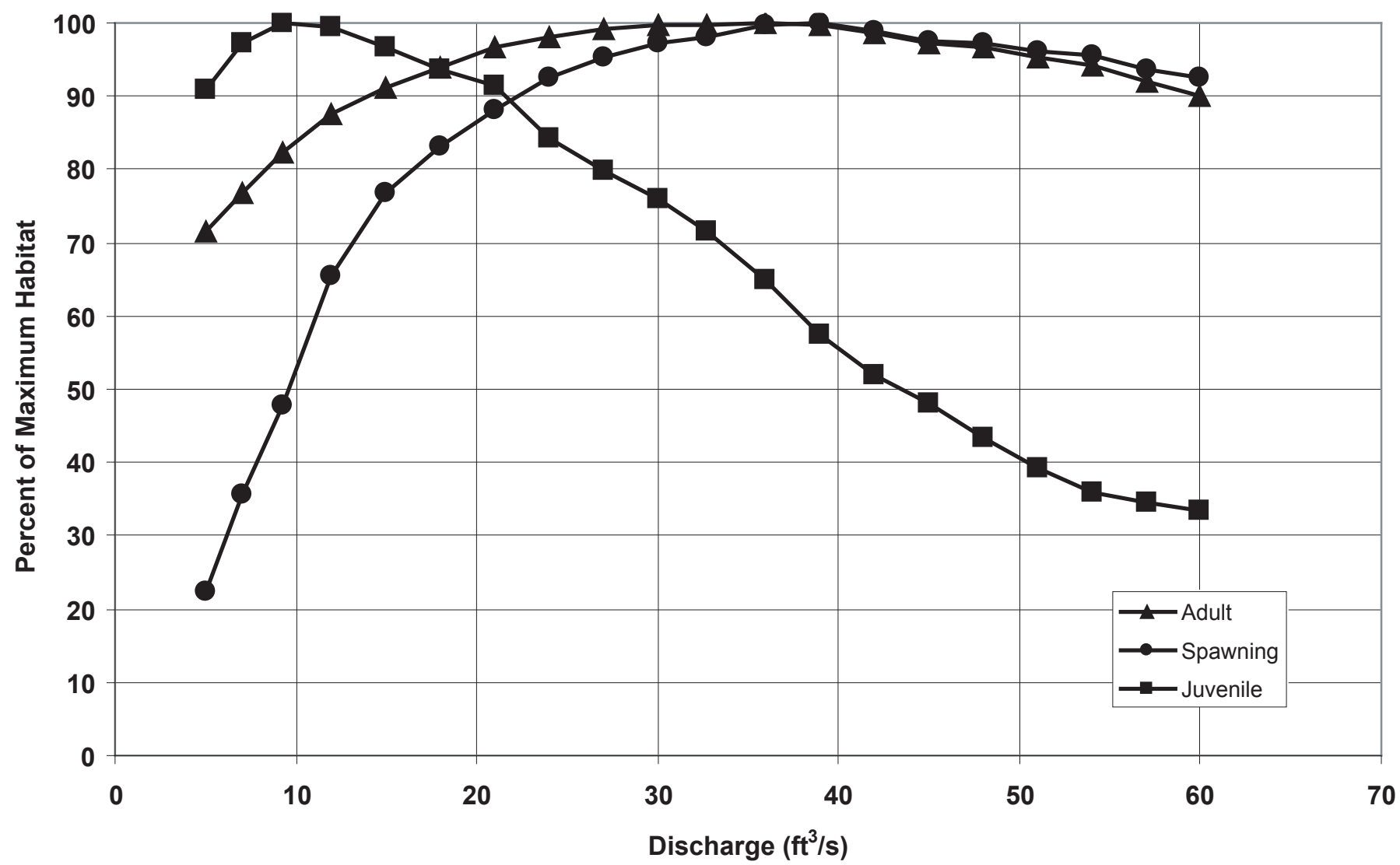


54 Instream Flow Characterization of Upper Salmon River Basin Streams, Central Idaho, 2003

Table 3A. Weighted usable area for bull trout, chinook salmon, steelhead trout life stages, and cover for juvenile life stages, site JC3, upper Fourth of July Creek, 2003

\section{BULL TROUT}

\begin{tabular}{lccccc}
$\begin{array}{c}\text { Discharge } \\
\left(\mathbf{f t}^{3} / \mathbf{s}\right)\end{array}$ & $\begin{array}{c}\text { Total Area } \\
\left(\mathbf{f t}^{2}\right)\end{array}$ & \multicolumn{3}{c}{ Summary of Weighted Usable Area $\left.\mathbf{f t}^{2} / \mathbf{1 0 0 0} \mathbf{f t}\right)$} \\
5 & 15424.0 & 7139.2 & 402.0 & 9253.0 & Cover \\
7 & 15775.8 & 7535.0 & 538.7 & 9653.4 & 1043.2 \\
9.32 & 16006.6 & 7714.1 & 652.8 & 9760.9 & 1110.9 \\
12 & 16210.0 & 7746.3 & 844.7 & 9666.6 & 1217.3 \\
15 & 16375.7 & 7758.0 & 998.1 & 9556.3 & 1259.7 \\
18 & 16508.6 & 7728.3 & 1161.7 & 9399.5 & 1270.9 \\
21 & 16636.2 & 7532.5 & 1359.7 & 9044.7 & 1271.2 \\
24 & 16754.0 & 7390.4 & 1466.3 & 8777.1 & 1317.3 \\
27 & 16867.1 & 7274.4 & 1549.2 & 8558.1 & 1317.8 \\
30 & 16970.9 & 7164.8 & 1656.1 & 8365.0 & 1311.1 \\
32.7 & 17055.4 & 7032.1 & 1730.6 & 8149.1 & 1318.5 \\
36 & 17151.9 & 6884.7 & 1807.8 & 7915.4 & 1309.2 \\
39 & 17249.8 & 6640.3 & 1871.4 & 7576.8 & 1290.7 \\
42 & 17359.5 & 6485.9 & 1918.4 & 7367.6 & 1266.0 \\
45 & 17497.3 & 6343.1 & 1958.9 & 7173.9 & 1277.7 \\
48 & 17621.5 & 6126.9 & 1993.2 & 6900.4 & 1262.7 \\
51 & 17743.1 & 5795.1 & 2012.0 & 6509.8 & 1233.9 \\
54 & 17858.7 & 5536.9 & 2011.1 & 6204.9 & 1177.9 \\
57 & 17968.9 & 5069.5 & 2002.5 & 5675.4 & 1092.7 \\
60 & 18074.92 & 4799.96 & 1986.7 & 5371.2 & 1047.8
\end{tabular}

\section{CHINOOK SALMON}

Discharge Total Area

\begin{tabular}{lc}
\multicolumn{1}{c}{$\left(\mathbf{f t}^{3} / \mathbf{s}\right)$} & $\left(\mathbf{f t}^{2}\right)$ \\
5 & 15424.0 \\
7 & 15775.8 \\
9.32 & 16006.6 \\
12 & 16210.0 \\
15 & 16375.7 \\
18 & 16508.6 \\
21 & 16636.2 \\
24 & 16754.0 \\
27 & 16867.1 \\
30 & 16970.9 \\
32.7 & 17055.4 \\
36 & 17151.9 \\
39 & 17249.8 \\
42 & 17359.5 \\
45 & 17497.3 \\
48 & 17621.5 \\
51 & 17743.1 \\
54 & 17858.7 \\
57 & 17968.9 \\
60 & 18074.92
\end{tabular}

\section{Summary of Weighted Usable Area ( $\left.\mathrm{ft}^{2} / 1000 \mathrm{ft}\right)$}

$\begin{array}{llcl}\text { Adult } & \text { Spawning } & \text { Juvenile } & \text { Cover } \\ 7425.0 & 1618.1 & 7775.1 & 829.5 \\ 7981.8 & 2568.5 & 8045.7 & 888.9 \\ 8539.8 & 3440.5 & 8082.4 & 927.2 \\ 9080.3 & 4708.2 & 8004.4 & 964.0 \\ 9456.1 & 5526.8 & 7726.0 & 983.3 \\ 9762.7 & 5992.2 & 7391.8 & 996.3 \\ 10026.6 & 6351.2 & 6921.6 & 1000.7 \\ 10185.4 & 6670.8 & 6527.6 & 996.1 \\ 10292.9 & 6871.1 & 6112.2 & 985.7 \\ 10343.6 & 6998.8 & 5683.6 & 969.2 \\ 10342.7 & 7067.6 & 5295.1 & 949.0 \\ 10384.7 & 7179.1 & 4936.4 & 913.4 \\ 10365.1 & 7206.0 & 4648.1 & 879.8 \\ 10228.2 & 7129.8 & 4353.6 & 850.5 \\ 10110.8 & 7035.8 & 4040.1 & 805.0 \\ 10044.6 & 7014.5 & 3661.3 & 773.3 \\ 9901.0 & 6922.0 & 3488.9 & 734.3 \\ 9780.2 & 6878.3 & 3291.1 & 696.3 \\ 9546.9 & 6757.5 & 3100.0 & 667.9 \\ 9357.03 & 6665 & 2931.36 & 650.61\end{array}$

Percent of Optimum

$\begin{array}{lll}\text { Adult } & \text { Spawning } & \text { Juvenile } \\ 92.02 & 19.98 & 94.80 \\ 97.12 & 26.77 & 98.90 \\ 99.43 & 32.45 & 100.00 \\ 99.85 & 41.98 & 99.03 \\ 100.00 & 49.61 & 97.90 \\ 99.62 & 57.74 & 96.30 \\ 97.09 & 67.58 & 92.66 \\ 95.26 & 72.88 & 89.92 \\ 93.77 & 77.00 & 87.68 \\ 92.35 & 82.31 & 85.70 \\ 90.64 & 86.01 & 83.49 \\ 88.74 & 89.85 & 81.09 \\ 85.59 & 93.01 & 77.62 \\ 83.60 & 95.35 & 75.48 \\ 81.76 & 97.36 & 73.50 \\ 78.97 & 99.07 & 70.69 \\ 74.70 & 100.00 & 66.69 \\ 71.37 & 99.96 & 63.57 \\ 65.35 & 99.53 & 58.14 \\ 61.87 & 98.74 & 55.03\end{array}$

\section{Percent of Optimum}

$\begin{array}{lll}\text { Adult } & \text { Spawning } & \text { Juvenile } \\ 71.50 & 22.46 & 96.20 \\ 76.86 & 35.64 & 99.55 \\ 82.23 & 47.75 & 100.00 \\ 87.44 & 65.34 & 99.04 \\ 91.06 & 76.70 & 95.59 \\ 94.01 & 83.16 & 91.46 \\ 96.55 & 88.14 & 85.64 \\ 98.08 & 92.57 & 80.76 \\ 99.12 & 95.35 & 75.62 \\ 99.60 & 97.13 & 70.32 \\ 99.60 & 98.08 & 65.51 \\ 100.00 & 99.63 & 61.08 \\ 99.81 & 100.00 & 57.51 \\ 98.49 & 98.94 & 53.87 \\ 97.36 & 97.64 & 49.99 \\ 96.73 & 97.34 & 45.30 \\ 95.34 & 96.06 & 43.17 \\ 94.18 & 95.45 & 40.72 \\ 91.93 & 93.78 & 38.36 \\ 90.10 & 92.49 & 36.27\end{array}$


Table 3A. Weighted usable area for bull trout, chinook salmon, steelhead trout life stages, and cover for juvenile life stages, site JC3, upper Fourth of July Creek, 2003-Continued

\section{STEELHEAD}

Discharge

$\left(\mathbf{f t}^{3} / \mathbf{s}\right)$

\section{5}

7

9.32

12

15

18

21

24

27

30

32.7

36

39

42

45

48

51

54

57

60
Total Area $\left(\mathrm{ft}^{2}\right)$

15424.0

15775.8

16006.6

16210.0

16375.7

16508.6

16636.2

16754.0

16867.1

16970.9

17055.4

17151.9

17249.8

17359.5

17497.3

17621.5

17743.1

17858.7

17968.9

18074.9
Summary of Weighted Usable Area ( $\mathrm{ft}^{2} / 1000 \mathrm{ft}$ )

Adult Spawning Juvenile Cover

$7425.0 \quad 1618.1$

$7981.8 \quad 2568.5$

$8539.8 \quad 3440.5$

$9080.3 \quad 4708.2$

$9456.1 \quad 5526.8$

$9762.7 \quad 5992.2$

\section{6}

10185.4

10292.9

10343.6

10342.7

$$
10384.7
$$

10365.1

10228.2

10110.8

10044.6

9901.0

9780.2

9546.9

9357.0
6351.2

6670.8

6871.1

6998.8

7067.6

7179.1

7206.0

7129.8

7035.8

7014.5

6922.0

6878.3

6757.5

6665.0

$11197.5 \quad 1097.3$

$11978.4 \quad 1224.4$

$12325.7 \quad 1303.3$

$12261.9 \quad 1372.2$

$11916.1 \quad 1458.6$

$11527.4 \quad 1515.1$

$11272.8 \quad 1544.2$

$10400.2 \quad 1562.9$

$9826.1 \quad 1570.8$

9360.3

8829.2

8014.4

7092.5

6395.4

5920.2

5350.6

4838.9

4413.8

4265.3

4126.0
1566.5

1546.0

1489.6

1384.7

1283.1

1192.1

1194.0

1189.5

1178.2

1160.9

1135.4
Percent of Optimum

$\begin{array}{lll}\text { Adult } & \text { Spawning } & \text { Juvenile } \\ 71.50 & 22.46 & 90.85 \\ 76.86 & 35.64 & 97.18 \\ 82.23 & 47.75 & 100.00 \\ 87.44 & 65.34 & 99.48 \\ 91.06 & 76.70 & 96.68 \\ 94.01 & 83.16 & 93.52 \\ 96.55 & 88.14 & 91.46 \\ 98.08 & 92.57 & 84.38 \\ 99.12 & 95.35 & 79.72 \\ 99.60 & 97.13 & 75.94 \\ 99.60 & 98.08 & 71.63 \\ 100.00 & 99.63 & 65.02 \\ 99.81 & 100.00 & 57.54 \\ 98.49 & 98.94 & 51.89 \\ 97.36 & 97.64 & 48.03 \\ 96.73 & 97.34 & 43.41 \\ 95.34 & 96.06 & 39.26 \\ 94.18 & 95.45 & 35.81 \\ 91.93 & 93.78 & 34.60 \\ 90.10 & 92.49 & 33.48 \\ & & \\ \end{array}$


Figure 17A

Percent of Contiguous Stream Width

Upper Fourth of July Creek - JC3

Passage Transect 5 (wide moderate slope)

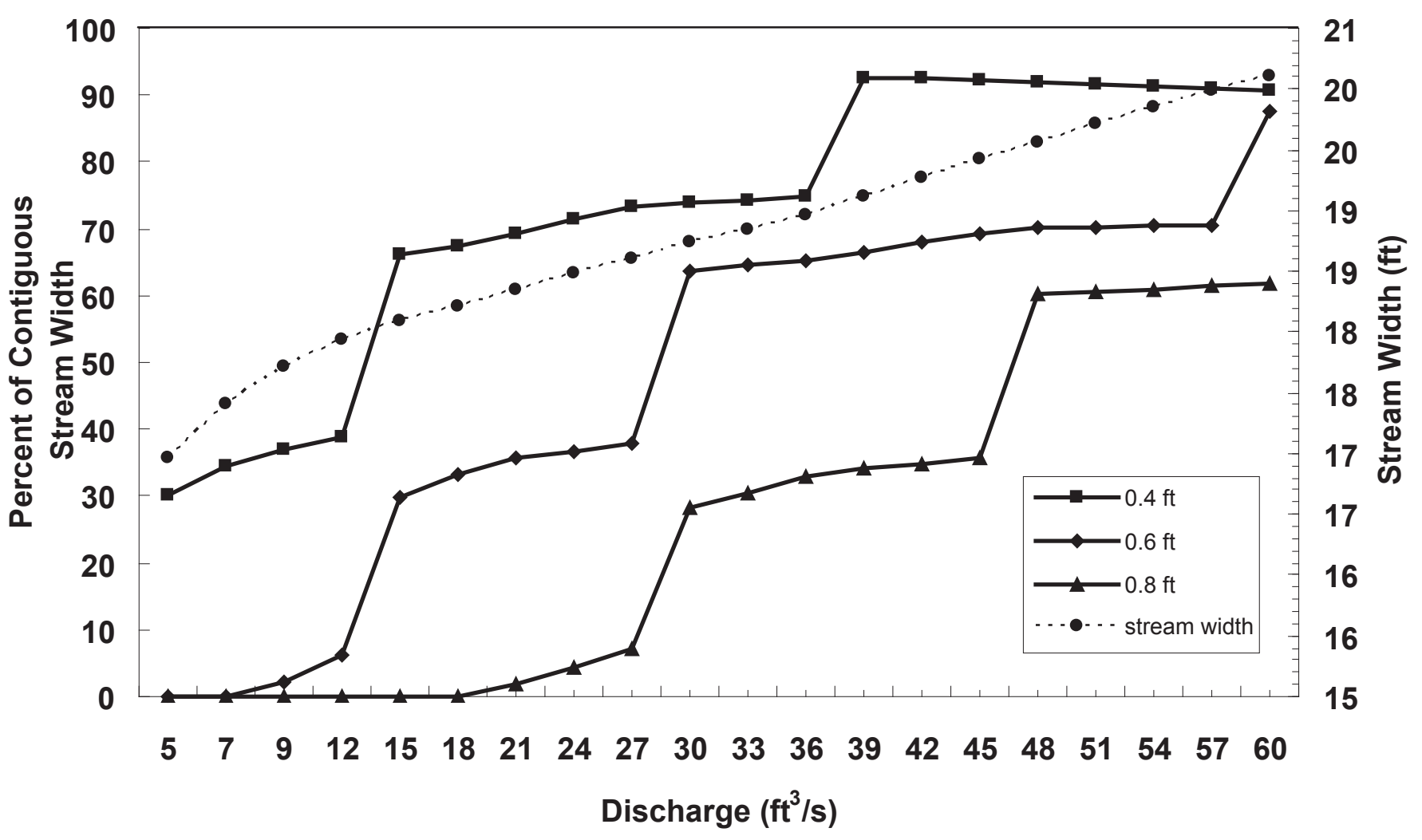

Discharge $\left(\mathrm{ft}^{3} / \mathrm{s}\right)$ 
Figure 18A

Percent of Total Stream Width

Upper Fourth of July Creek - JC3

Passage Transect 5 (wide moderate slope)

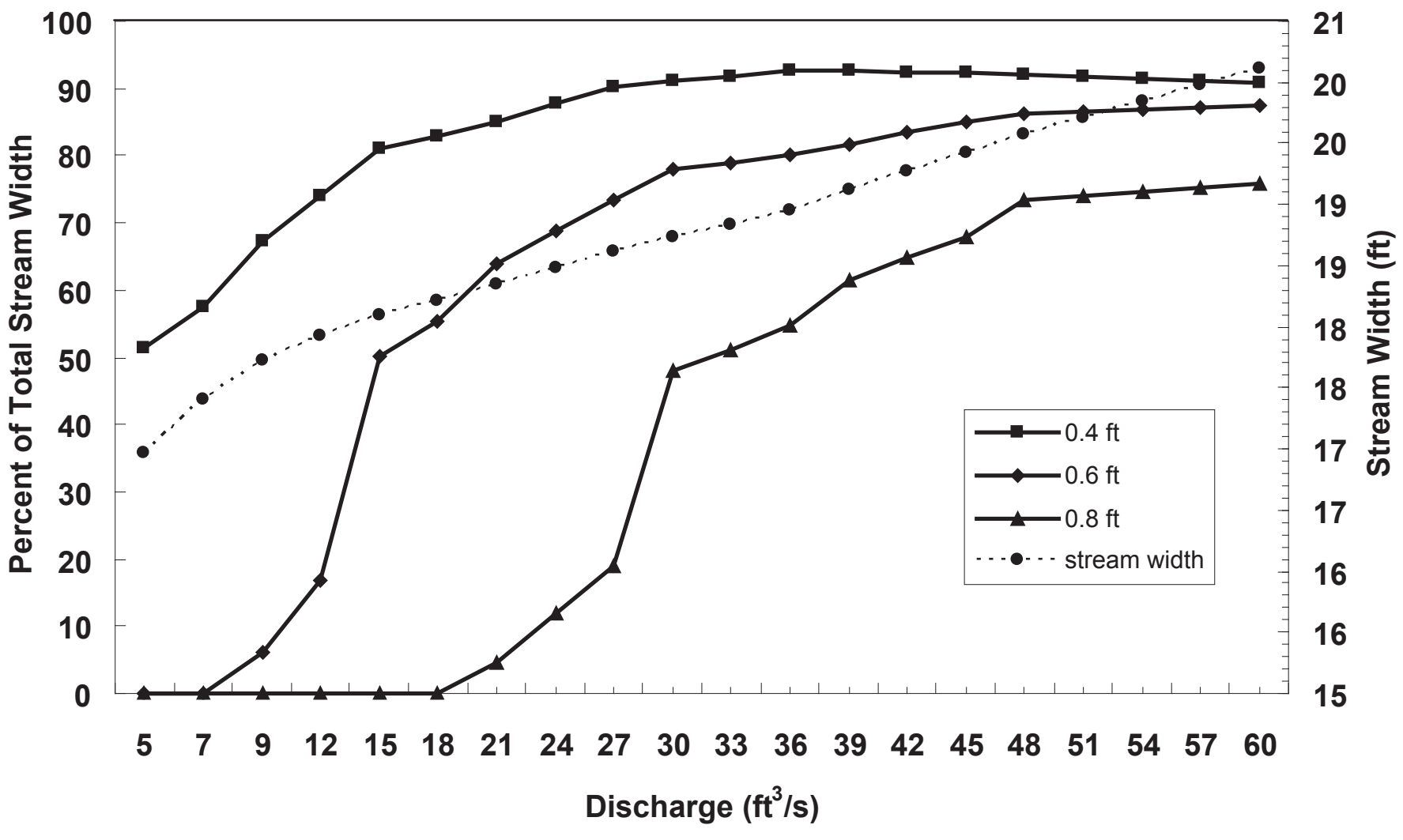


Table 4A. Passage criteria assessment for transect 5 (wide moderate slope), site JC3, upper Fourth of July Creek, 2003

\begin{tabular}{|c|c|c|c|c|c|}
\hline $\begin{array}{c}\text { Discharge } \\
\left(\mathrm{ft}^{3} / \mathrm{s}\right)\end{array}$ & $\begin{array}{c}\text { Stream width } \\
\text { (ft) }\end{array}$ & $\begin{array}{l}\text { Total Stream } \\
\text { Width Greater } \\
\text { Than } 0.4 \mathrm{ft} \text { depth }\end{array}$ & $\begin{array}{l}\text { Percent Stream } \\
\text { Width Greater } \\
\text { Than } 0.4 \text { ft Depth }\end{array}$ & $\begin{array}{c}\text { Contiguous Stream } \\
\text { Width Greater Than } \\
0.4 \mathrm{ft} \text { Depth }\end{array}$ & $\begin{array}{l}\text { Percent Contiguous } \\
\text { Stream Width Greater } \\
\text { Than } 0.4 \mathrm{ft} \text { Depth }\end{array}$ \\
\hline 5 & 16.96 & 8.72 & 51.38 & 5.11 & 30.12 \\
\hline 7 & 17.41 & 10.00 & 57.42 & 6.00 & 34.44 \\
\hline 9.32 & 17.72 & 11.92 & 67.24 & 6.57 & 37.09 \\
\hline 12 & 17.93 & 13.29 & 74.13 & 6.94 & 38.68 \\
\hline 15 & 18.09 & 14.65 & 80.97 & 11.98 & 66.20 \\
\hline 18 & 18.21 & 15.07 & 82.77 & 12.27 & 67.41 \\
\hline 21 & 18.35 & 15.62 & 85.16 & 12.71 & 69.27 \\
\hline 24 & 18.48 & 16.21 & 87.72 & 13.19 & 71.39 \\
\hline 27 & 18.61 & 16.78 & 90.18 & 13.66 & 73.43 \\
\hline 30 & 18.73 & 17.07 & 91.12 & 13.86 & 73.97 \\
\hline 32.7 & 18.84 & 17.29 & 91.79 & 14.00 & 74.33 \\
\hline 36 & 18.96 & 17.55 & 92.58 & 14.17 & 74.74 \\
\hline 39 & 19.11 & 17.70 & 92.58 & 17.70 & 92.58 \\
\hline 42 & 19.28 & 17.81 & 92.40 & 17.81 & 92.40 \\
\hline 45 & 19.43 & 17.92 & 92.24 & 17.92 & 92.24 \\
\hline 48 & 19.57 & 18.01 & 92.05 & 18.01 & 92.05 \\
\hline 51 & 19.71 & 18.08 & 91.71 & 18.08 & 91.71 \\
\hline 54 & 19.85 & 18.14 & 91.40 & 18.14 & 91.40 \\
\hline 57 & 19.98 & 18.20 & 91.11 & 18.20 & 91.11 \\
\hline 60 & 20.11 & 18.26 & 90.83 & 18.26 & 90.83 \\
\hline $\begin{array}{c}\text { Discharge } \\
\left(\mathrm{ft}^{3} / \mathrm{s}\right)\end{array}$ & $\begin{array}{c}\text { Stream width } \\
\text { (ft) }\end{array}$ & $\begin{array}{c}\text { Total Stream } \\
\text { Width Greater } \\
\text { Than } 0.6 \mathrm{ft} \text { Depth }\end{array}$ & $\begin{array}{l}\text { Percent Stream } \\
\text { Width Greater } \\
\text { Than } 0.6 \text { ft Depth }\end{array}$ & $\begin{array}{c}\text { Contiguous Stream } \\
\text { Width Greater Than } \\
0.6 \mathrm{ft} \text { Depth }\end{array}$ & $\begin{array}{l}\text { Percent Contiguous } \\
\text { Stream Width Greater } \\
\text { Than } 0.6 \mathrm{ft} \text { Depth }\end{array}$ \\
\hline 5 & 16.96 & 0.00 & 0.00 & 0.00 & 0.00 \\
\hline 7 & 17.41 & 0.00 & 0.00 & 0.00 & 0.00 \\
\hline 9.32 & 17.72 & 1.09 & 6.16 & 0.41 & 2.30 \\
\hline 12 & 17.93 & 3.02 & 16.82 & 1.13 & 6.28 \\
\hline 15 & 18.09 & 9.09 & 50.25 & 5.37 & 29.67 \\
\hline 18 & 18.21 & 10.11 & 55.49 & 6.07 & 33.34 \\
\hline 21 & 18.35 & 11.75 & 64.04 & 6.53 & 35.59 \\
\hline 24 & 18.48 & 12.71 & 68.80 & 6.78 & 36.71 \\
\hline 27 & 18.61 & 13.66 & 73.38 & 7.03 & 37.78 \\
\hline 30 & 18.73 & 14.62 & 78.03 & 11.96 & 63.82 \\
\hline 32.7 & 18.84 & 14.88 & 79.00 & 12.14 & 64.45 \\
\hline 36 & 18.96 & 15.19 & 80.14 & 12.36 & 65.19 \\
\hline 39 & 19.11 & 15.63 & 81.76 & 12.71 & 66.51 \\
\hline 42 & 19.28 & 16.08 & 83.43 & 13.09 & 67.89 \\
\hline 45 & 19.43 & 16.50 & 84.96 & 13.43 & 69.16 \\
\hline 48 & 19.57 & 16.86 & 86.18 & 13.73 & 70.14 \\
\hline 51 & 19.71 & 17.07 & 86.57 & 13.86 & 70.28 \\
\hline 54 & 19.85 & 17.26 & 86.93 & 13.98 & 70.41 \\
\hline 57 & 19.98 & 17.44 & 87.26 & 14.09 & 70.54 \\
\hline 60 & 20.11 & 17.60 & 87.55 & 17.60 & 87.55 \\
\hline
\end{tabular}


Table 4A. Passage criteria assessment for transect 5 (wide moderate slope), site JC3, upper Fourth of July Creek, 2003 — Continued

\begin{tabular}{|c|c|c|c|c|c|}
\hline $\begin{array}{c}\text { Discharge } \\
\left(\mathrm{ft}^{3} / \mathbf{s}\right)\end{array}$ & $\begin{array}{l}\text { Stream width } \\
\text { (ft) }\end{array}$ & $\begin{array}{l}\text { Total Stream } \\
\text { Width Greater } \\
\text { Than } 0.8 \mathrm{ft} \text { Depth }\end{array}$ & $\begin{array}{l}\text { Percent Stream } \\
\text { Width Greater } \\
\text { Than } 0.8 \mathrm{ft} \text { Depth }\end{array}$ & $\begin{array}{l}\text { Contiguous Stream } \\
\text { Width Greater Than } \\
0.8 \mathrm{ft} \text { Depth }\end{array}$ & $\begin{array}{l}\text { Percent Contiguous } \\
\text { Stream Width Greater } \\
\text { Than } \mathbf{0 . 8} \mathrm{ft} \text { Depth }\end{array}$ \\
\hline 5 & 16.96 & 0.00 & 0.00 & 0.00 & 0.00 \\
\hline 7 & 17.41 & 0.00 & 0.00 & 0.00 & 0.00 \\
\hline 9.32 & 17.72 & 0.00 & 0.00 & 0.00 & 0.00 \\
\hline 12 & 17.93 & 0.00 & 0.00 & 0.00 & 0.00 \\
\hline 15 & 18.09 & 0.00 & 0.00 & 0.00 & 0.00 \\
\hline 18 & 18.21 & 0.00 & 0.00 & 0.00 & 0.00 \\
\hline 21 & 18.35 & 0.86 & 4.68 & 0.32 & 1.75 \\
\hline 24 & 18.48 & 2.21 & 11.94 & 0.82 & 4.46 \\
\hline 27 & 18.61 & 3.52 & 18.91 & 1.31 & 7.06 \\
\hline 30 & 18.73 & 9.02 & 48.14 & 5.32 & 28.39 \\
\hline 32.7 & 18.84 & 9.65 & 51.21 & 5.75 & 30.54 \\
\hline 36 & 18.96 & 10.39 & 54.83 & 6.27 & 33.07 \\
\hline 39 & 19.11 & 11.76 & 61.51 & 6.53 & 34.17 \\
\hline 42 & 19.28 & 12.50 & 64.86 & 6.73 & 34.90 \\
\hline 45 & 19.43 & 13.20 & 67.93 & 6.91 & 35.57 \\
\hline 48 & 19.57 & 14.37 & 73.45 & 11.78 & 60.22 \\
\hline 51 & 19.71 & 14.61 & 74.12 & 11.95 & 60.63 \\
\hline 54 & 19.85 & 14.84 & 74.75 & 12.11 & 61.01 \\
\hline 57 & 19.98 & 15.05 & 75.34 & 12.26 & 61.37 \\
\hline 60 & 20.11 & 15.26 & 75.91 & 12.41 & 61.73 \\
\hline
\end{tabular}




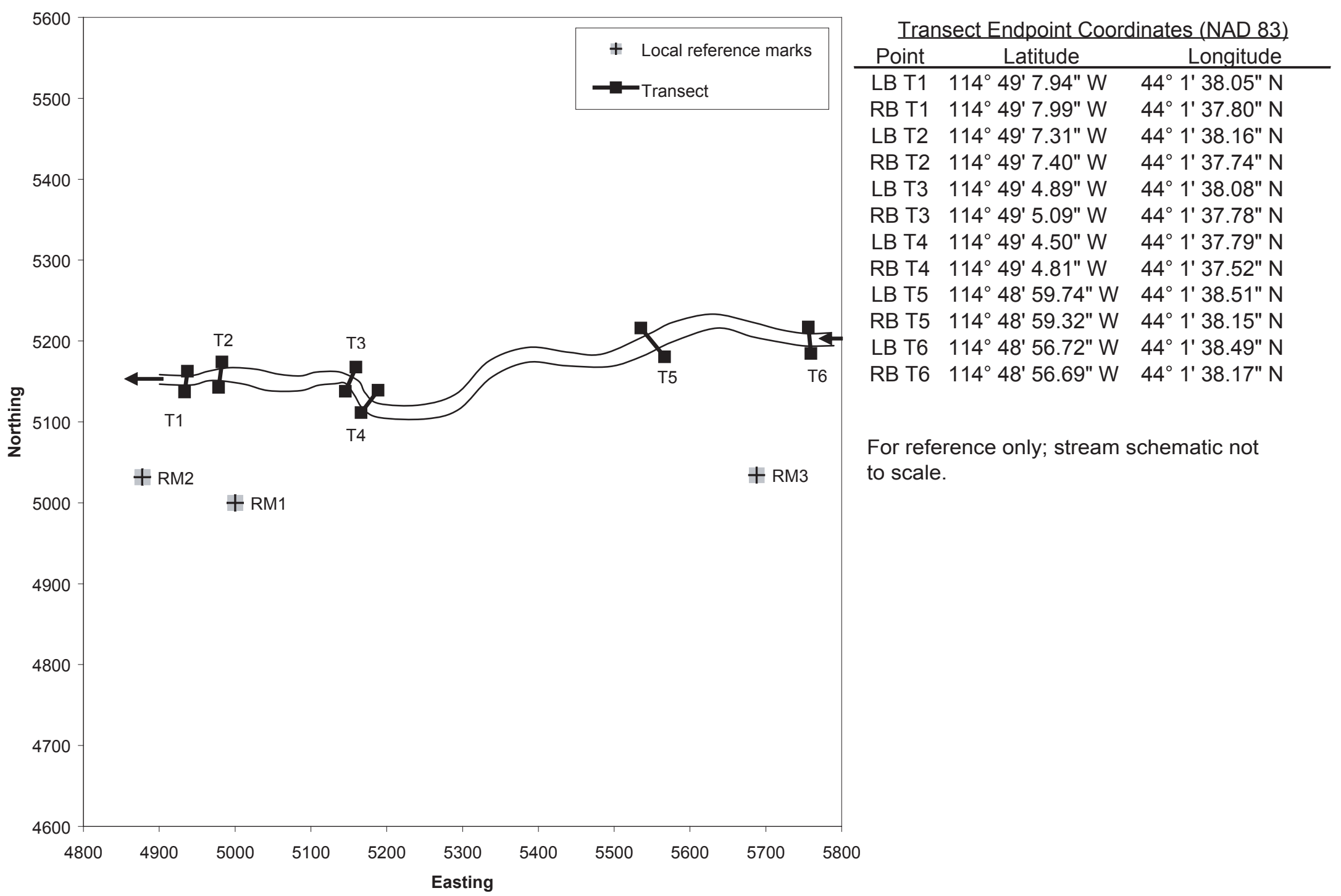

Figure 19A

Middle Fourth of July Creek - JC2

Plan View 
Figure 20A

Middle Fourth of July Creek - JC2

Bull Trout WUA

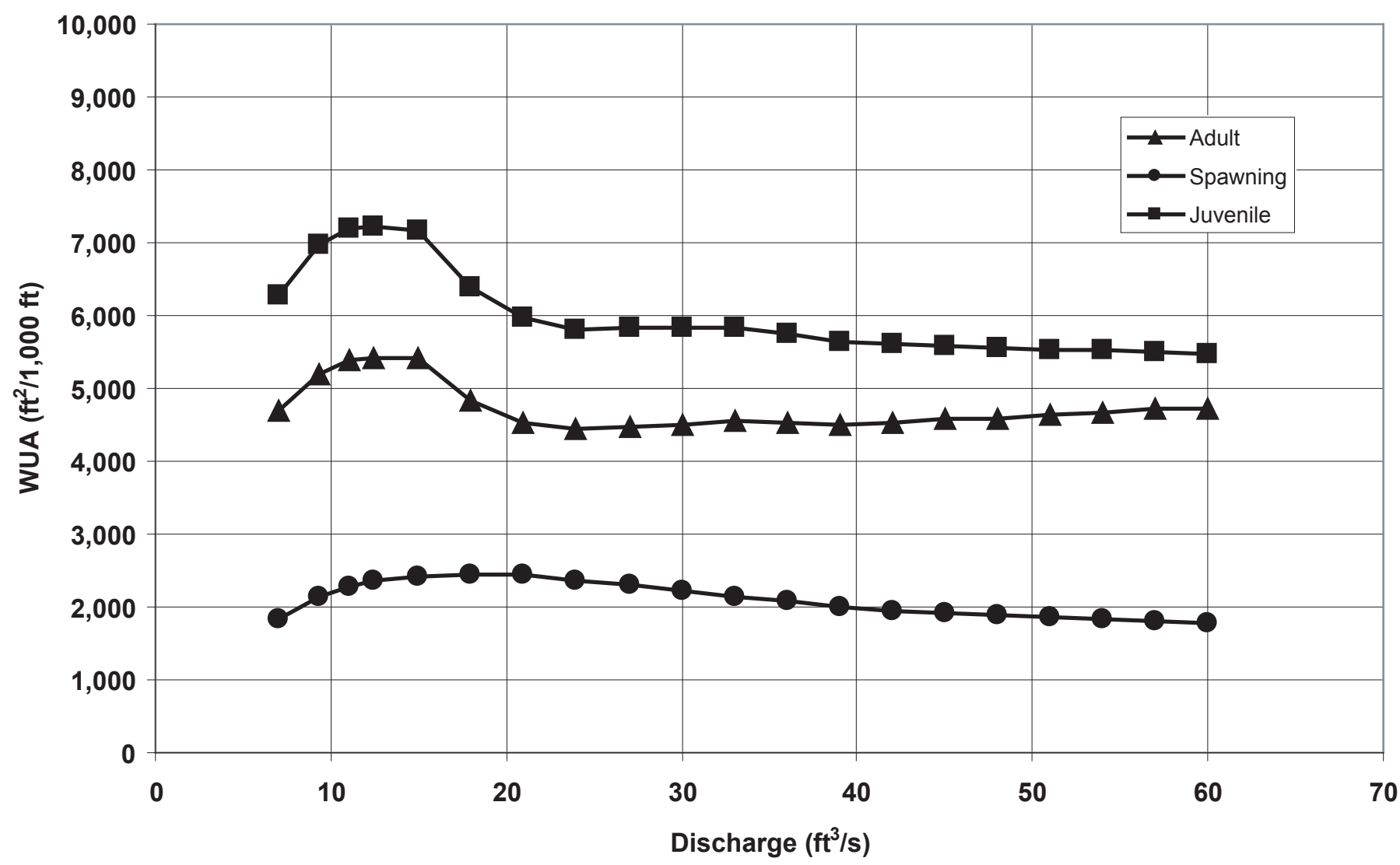


Figure 21A

Middle Fourth of July Creek - JC2

Bull Trout WUA Normalized

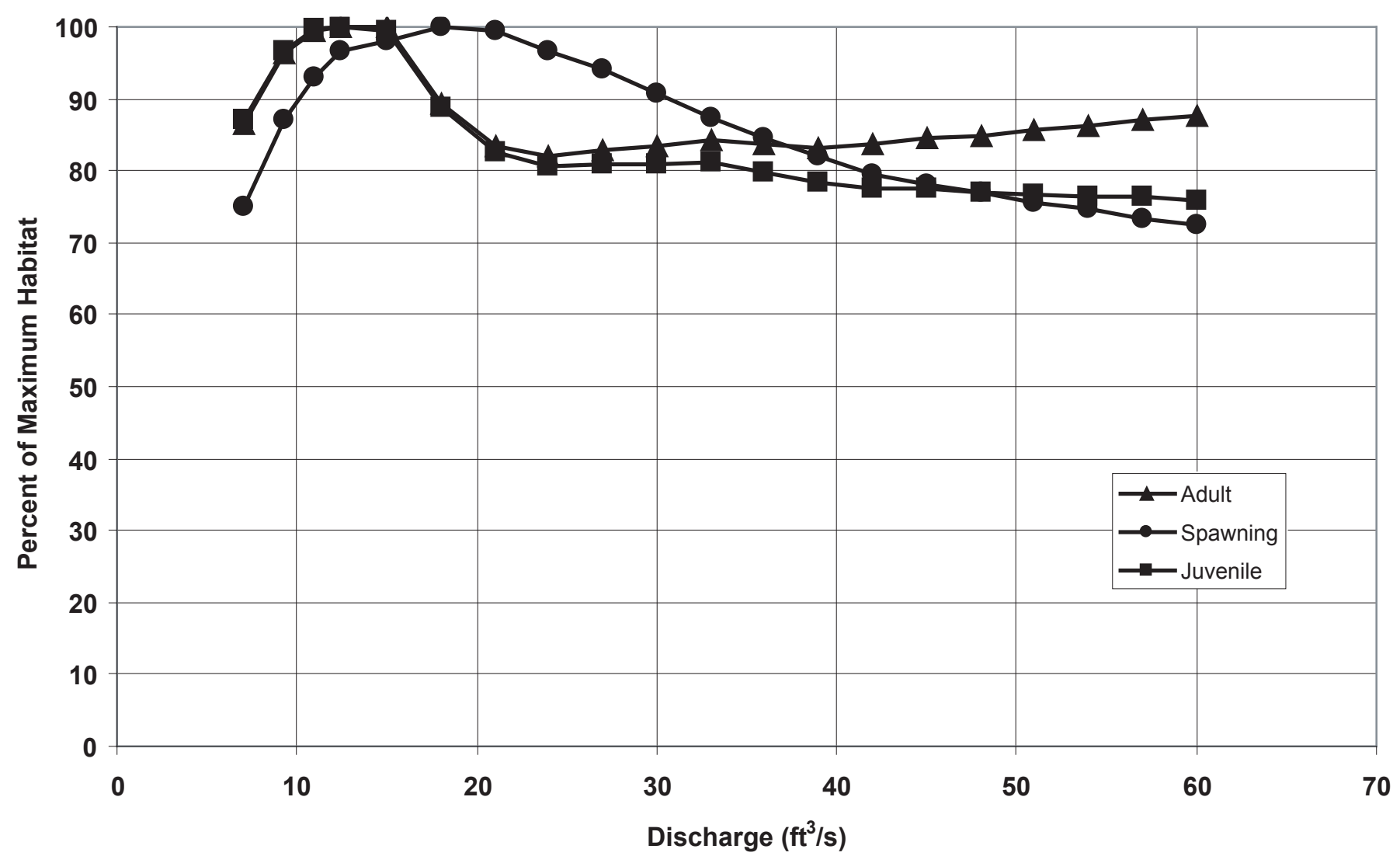


Figure 22A

Middle Fourth of July Creek - JC2

Chinook Salmon WUA

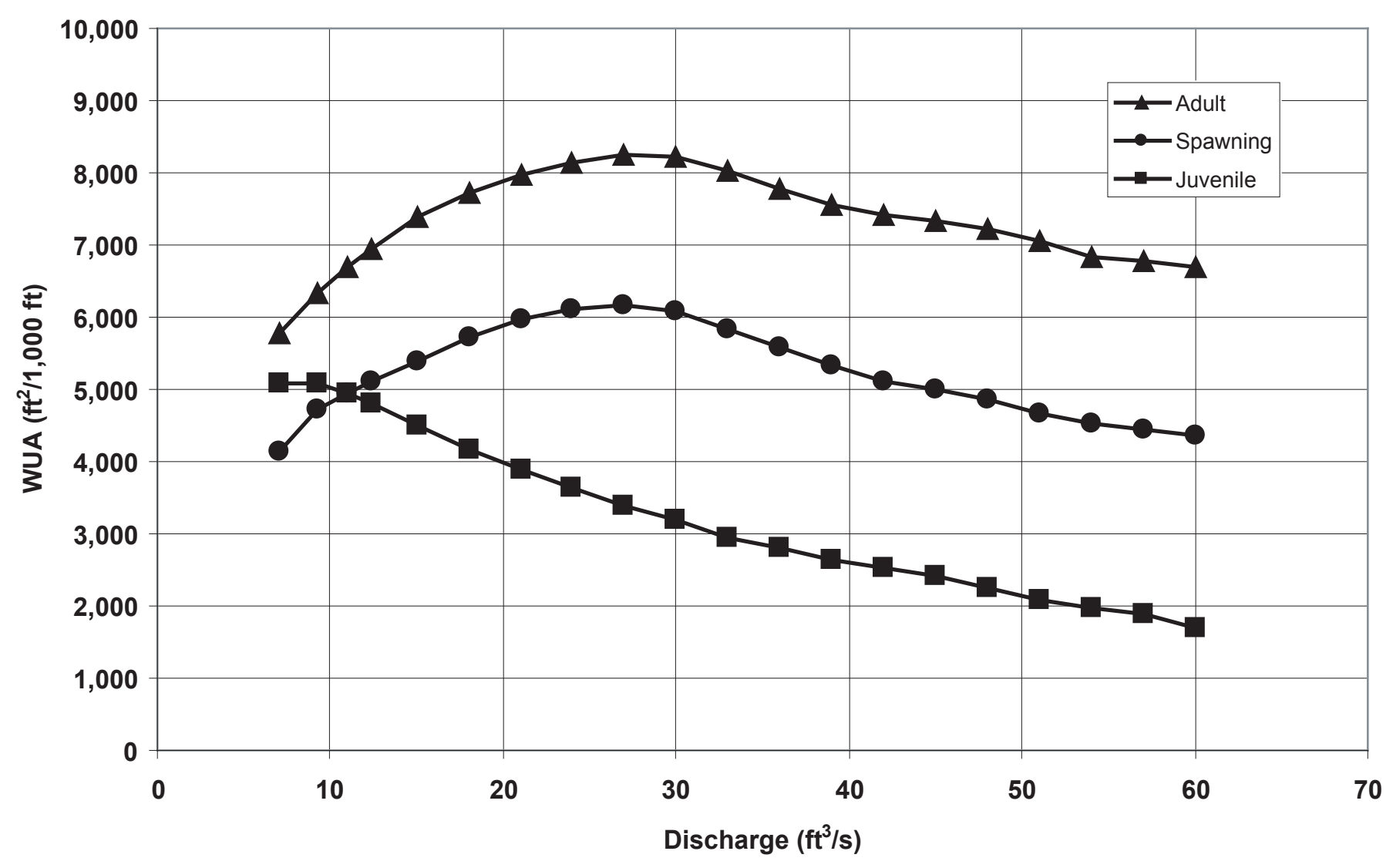


Figure 23A

Middle Fourth of July Creek - JC2

Chinook Salmon WUA Normalized

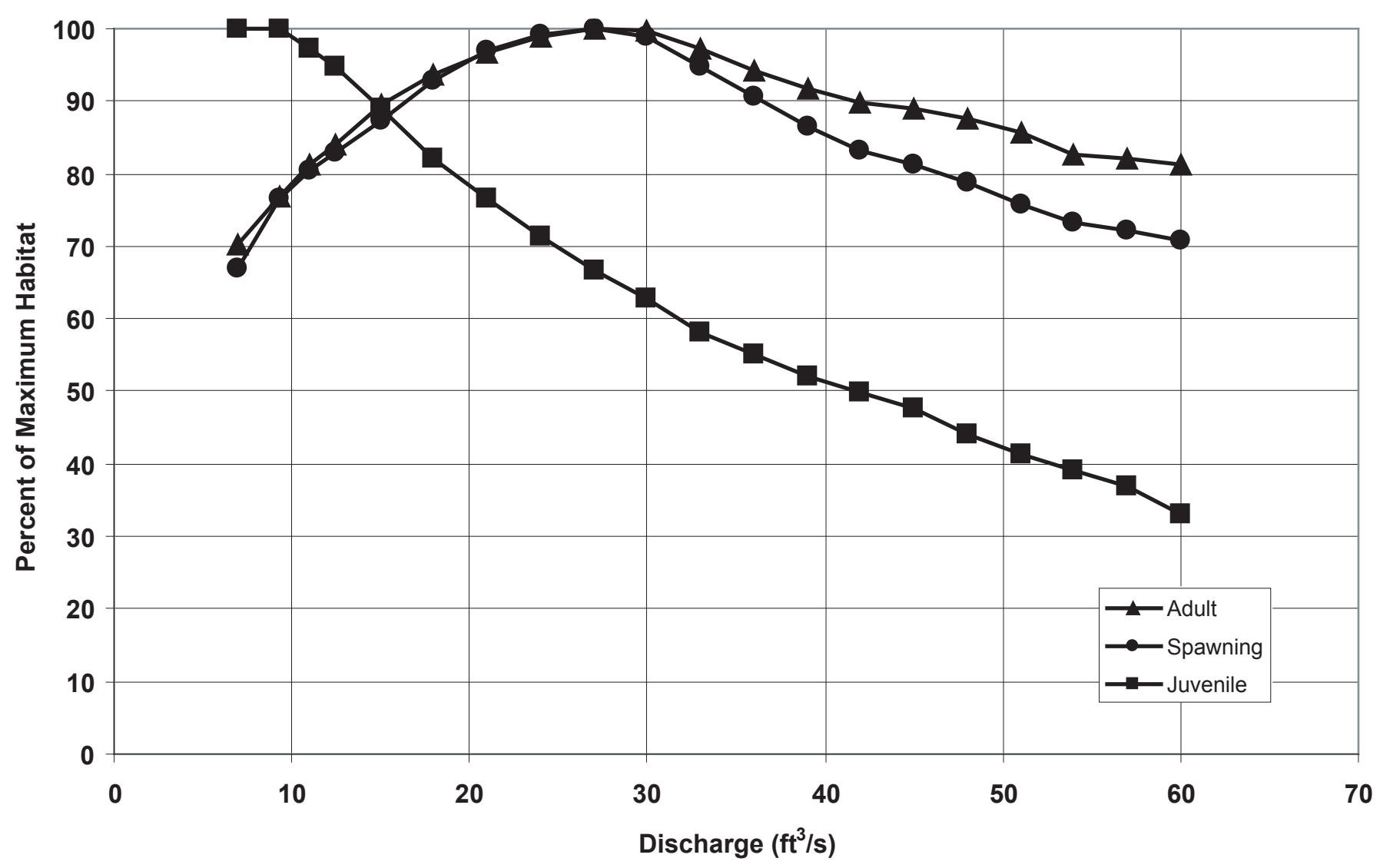


Figure 24A

Middle Fourth of July Creek - JC2

Steelhead WUA

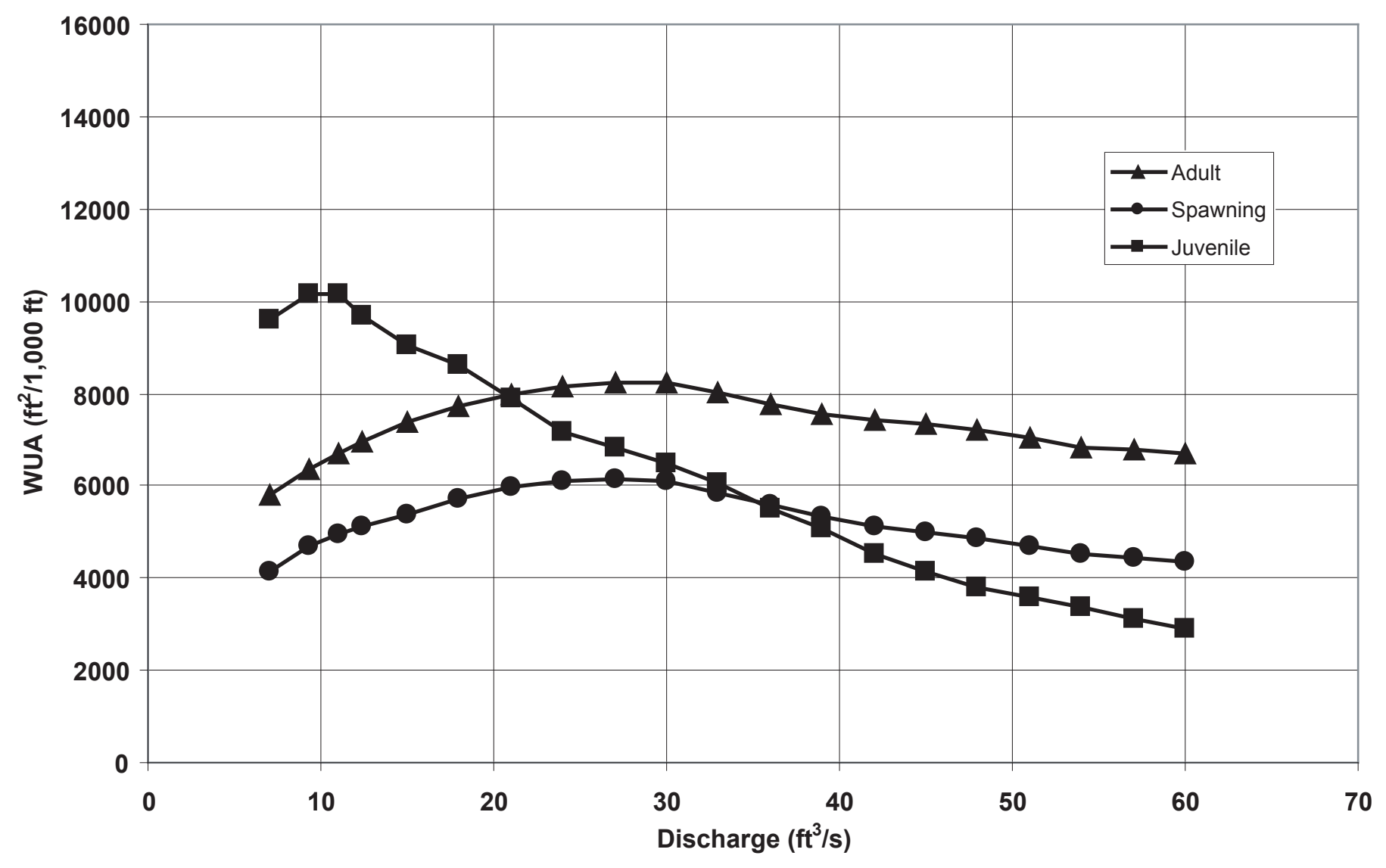


Figure 25A

Middle Fourth of July Creek - JC2

Steelhead WUA Normalized

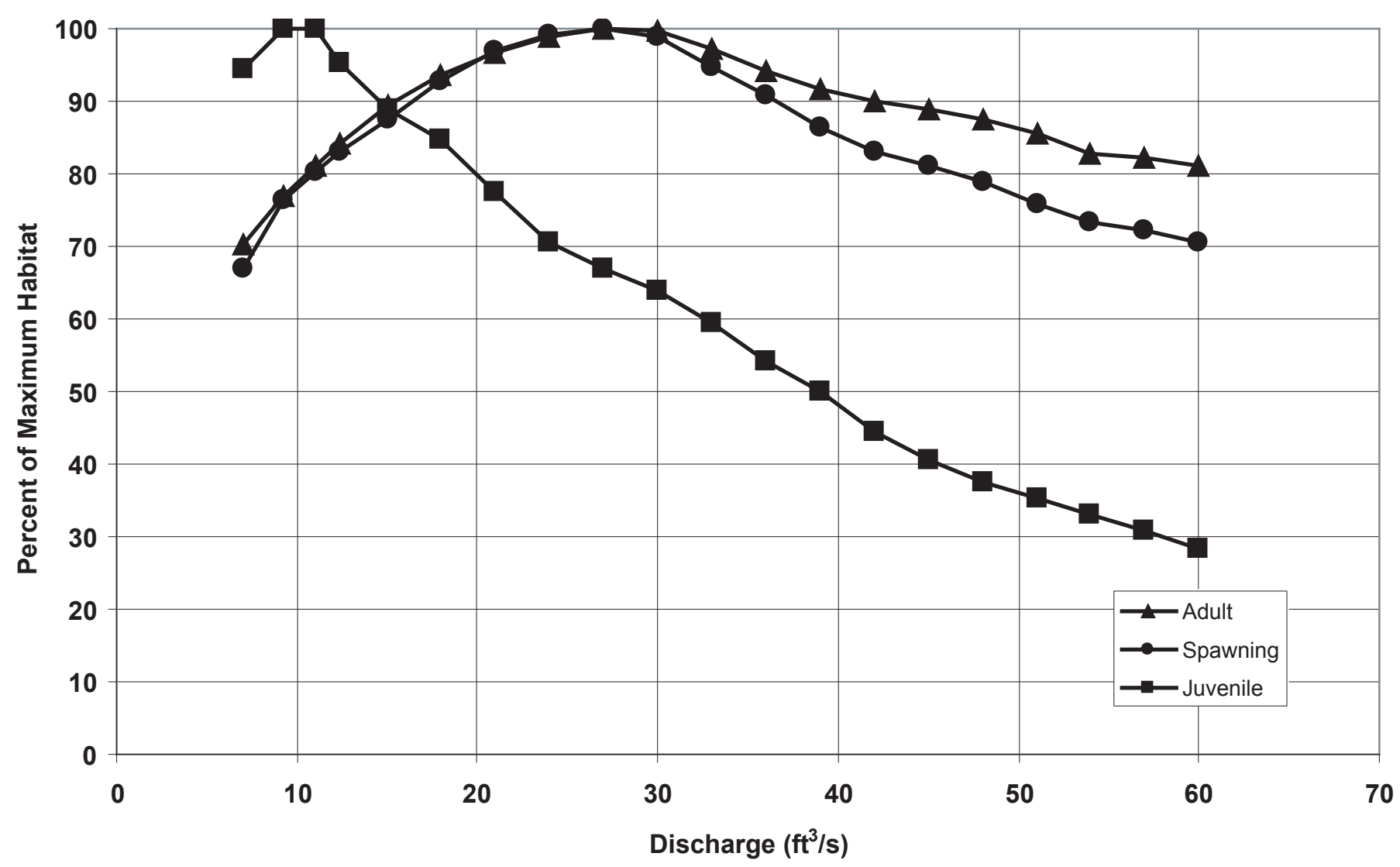


Table 5A. Weighted usable area for bull trout, chinook salmon, steelhead trout life stages, and cover for juvenile life stages, site JC2, middle Fourth of July Creek, 2003

\section{BULL TROUT}

\begin{tabular}{|c|c|c|c|c|c|c|c|c|}
\hline \multirow{2}{*}{$\begin{array}{c}\text { Discharge } \\
\left(\mathrm{ft}^{3} / \mathrm{s}\right)\end{array}$} & \multirow{2}{*}{$\begin{array}{c}\text { Total Area } \\
\left(\mathrm{ft}^{2}\right)\end{array}$} & \multicolumn{4}{|c|}{ Summary of Weighted Usable Area $\left(\mathrm{ft}^{2} / 1000 \mathrm{ft}\right)$} & \multicolumn{3}{|c|}{ Percent of Optimum } \\
\hline & & Adult & Spawning & Juvenile & Cover & Adult & Spawning & Juvenile \\
\hline 7 & 13294.4 & 4687.8 & 1842.5 & 6288.0 & 2244.1 & 86.64 & 75.09 & 87.19 \\
\hline 9.3 & 14015.8 & 5207.2 & 2135.1 & 6970.8 & 2462.0 & 96.24 & 87.02 & 96.66 \\
\hline 11 & 14246.1 & 5387.7 & 2282.8 & 7199.0 & 2626.6 & 99.57 & 93.03 & 99.82 \\
\hline 12.4 & 14430.3 & 5410.8 & 2368.1 & 7211.9 & 2658.3 & 100.00 & 96.51 & 100.00 \\
\hline 15 & 14838.3 & 5403.2 & 2405.9 & 7172.8 & 2739.2 & 99.86 & 98.05 & 99.46 \\
\hline 18 & 15221.3 & 4833.5 & 2453.7 & 6397.2 & 2557.4 & 89.33 & 100.00 & 88.70 \\
\hline 21 & 15429.8 & 4518.6 & 2438.3 & 5959.1 & 2482.6 & 83.51 & 99.37 & 82.63 \\
\hline 24 & 15613.2 & 4432.4 & 2368.7 & 5814.4 & 2395.8 & 81.92 & 96.54 & 80.62 \\
\hline 27 & 15774.6 & 4482.6 & 2310.8 & 5837.6 & 2416.6 & 82.85 & 94.18 & 80.94 \\
\hline 30 & 15922.8 & 4508.8 & 2223.9 & 5828.2 & 2422.3 & 83.33 & 90.63 & 80.81 \\
\hline 33 & 16069.8 & 4562.6 & 2143.0 & 5846.9 & 2426.3 & 84.32 & 87.34 & 81.07 \\
\hline 36 & 16213.7 & 4536.0 & 2075.3 & 5755.7 & 2384.8 & 83.83 & 84.58 & 79.81 \\
\hline 39 & 16349.8 & 4503.5 & 2010.7 & 5648.8 & 2315.0 & 83.23 & 81.95 & 78.33 \\
\hline 42 & 16478.6 & 4522.2 & 1949.3 & 5600.0 & 2264.8 & 83.58 & 79.44 & 77.65 \\
\hline 45 & 16599.8 & 4571.5 & 1916.7 & 5592.0 & 2240.8 & 84.49 & 78.11 & 77.54 \\
\hline 48 & 16716.2 & 4589.6 & 1887.7 & 5547.2 & 2190.6 & 84.82 & 76.93 & 76.92 \\
\hline 51 & 16826.9 & 4634.1 & 1854.1 & 5533.7 & 2173.0 & 85.64 & 75.56 & 76.73 \\
\hline 54 & 16932.1 & 4672.6 & 1830.3 & 5517.4 & 2152.8 & 86.36 & 74.59 & 76.50 \\
\hline 57 & 17035.8 & 4712.3 & 1797.8 & 5502.6 & 2135.1 & 87.09 & 73.27 & 76.30 \\
\hline 60 & 17139.17 & 4735.53 & 1777.4 & 5477.1 & 2114.1 & 87.52 & 72.44 & 75.95 \\
\hline
\end{tabular}

\section{CHINOOK SALMON}

\begin{tabular}{|c|c|c|c|c|c|c|c|c|}
\hline \multirow{2}{*}{$\begin{array}{c}\text { Discharge } \\
\left(\mathrm{ft}^{3} / \mathrm{s}\right)\end{array}$} & \multirow{2}{*}{$\begin{array}{c}\text { Total Area } \\
\left(\mathrm{ft}^{2}\right)\end{array}$} & \multicolumn{4}{|c|}{ Summary of Weighted Usable Area ( $\left.\mathrm{ft}^{2} / 1000 \mathrm{ft}\right)$} & \multicolumn{3}{|c|}{ Percent of Optimum } \\
\hline & & Adult & Spawning & Juvenile & Cover & Adult & Spawning & Juvenile \\
\hline 7 & 13294.4 & 5790.6 & 4131.3 & 5071.2 & 1913.7 & 70.22 & 67.02 & 99.90 \\
\hline 9.3 & 14015.8 & 6344.1 & 4714.7 & 5076.1 & 1963.9 & 76.94 & 76.49 & 100.00 \\
\hline 11 & 14246.1 & 6692.8 & 4954.0 & 4942.0 & 1941.0 & 81.16 & 80.37 & 97.36 \\
\hline 12.4 & 14430.3 & 6936.3 & 5111.4 & 4807.6 & 1906.1 & 84.12 & 82.92 & 94.71 \\
\hline 15 & 14838.3 & 7375.0 & 5390.0 & 4510.1 & 1818.2 & 89.44 & 87.44 & 88.85 \\
\hline 18 & 15221.3 & 7727.9 & 5717.0 & 4172.9 & 1701.4 & 93.72 & 92.75 & 82.21 \\
\hline 21 & 15429.8 & 7967.3 & 5977.7 & 3891.1 & 1576.6 & 96.62 & 96.98 & 76.66 \\
\hline 24 & 15613.2 & 8144.9 & 6116.1 & 3626.9 & 1454.0 & 98.77 & 99.22 & 71.45 \\
\hline 27 & 15774.6 & 8246.0 & 6164.1 & 3381.2 & 1312.2 & 100.00 & 100.00 & 66.61 \\
\hline 30 & 15922.8 & 8230.4 & 6094.6 & 3186.0 & 1216.6 & 99.81 & 98.87 & 62.76 \\
\hline 33 & 16069.8 & 8021.9 & 5838.7 & 2954.3 & 1144.8 & 97.28 & 94.72 & 58.20 \\
\hline 36 & 16213.7 & 7768.1 & 5593.7 & 2796.1 & 1042.0 & 94.21 & 90.75 & 55.08 \\
\hline 39 & 16349.8 & 7560.1 & 5331.8 & 2636.5 & 924.0 & 91.68 & 86.50 & 51.94 \\
\hline 42 & 16478.6 & 7413.4 & 5122.1 & 2527.5 & 861.6 & 89.90 & 83.10 & 49.79 \\
\hline 45 & 16599.8 & 7337.1 & 5004.3 & 2414.6 & 807.0 & 88.98 & 81.18 & 47.57 \\
\hline 48 & 16716.2 & 7223.7 & 4854.8 & 2238.3 & 672.3 & 87.60 & 78.76 & 44.09 \\
\hline 51 & 16826.9 & 7055.7 & 4676.6 & 2094.0 & 581.8 & 85.57 & 75.87 & 41.25 \\
\hline 54 & 16932.1 & 6825.9 & 4513.9 & 1985.0 & 550.0 & 82.78 & 73.23 & 39.11 \\
\hline 57 & 17035.8 & 6773.8 & 4456.0 & 1877.0 & 518.6 & 82.15 & 72.29 & 36.98 \\
\hline 60 & 17139.17 & 6691.81 & 4357.61 & 1681.09 & 478.98 & 81.15 & 70.69 & 33.12 \\
\hline
\end{tabular}




\section{Instream Flow Characterization of Upper Salmon River Basin Streams, Central Idaho, 2003}

Table 5A. Weighted usable area for bull trout, chinook salmon, steelhead trout life stages, and cover for juvenile life stages, site JC2, middle Fourth of July Creek, 2003-Continued

\section{STEELHEAD}

\begin{tabular}{|c|c|c|c|c|c|c|c|c|}
\hline \multirow{2}{*}{$\begin{array}{c}\text { Discharge } \\
\left(\mathrm{ft}^{3} / \mathrm{s}\right)\end{array}$} & \multirow{2}{*}{$\begin{array}{c}\text { Total Area } \\
\quad\left(\mathrm{ft}^{2}\right)\end{array}$} & \multicolumn{4}{|c|}{ Summary of Weighted Usable Area $\left(\mathrm{ft}^{2} / 1000 \mathrm{ft}\right)$} & \multicolumn{3}{|c|}{ Percent of Optimum } \\
\hline & & Adult & Spawning & Juvenile & Cover & Adult & Spawning & Juvenile \\
\hline 7 & 13294.4 & 5790.6 & 4131.3 & 9611.8 & 3646.5 & 70.22 & 67.02 & 94.56 \\
\hline 9.3 & 14015.8 & 6344.1 & 4714.7 & 10164.5 & 3905.1 & 76.94 & 76.49 & 100.00 \\
\hline 11 & 14246.1 & 6692.8 & 4954.0 & 10163.8 & 3991.9 & 81.16 & 80.37 & 99.99 \\
\hline 12.4 & 14430.3 & 6936.3 & 5111.4 & 9680.0 & 3944.6 & 84.12 & 82.92 & 95.23 \\
\hline 15 & 14838.3 & 7375.0 & 5390.0 & 9040.0 & 3708.2 & 89.44 & 87.44 & 88.94 \\
\hline 18 & 15221.3 & 7727.9 & 5717.0 & 8620.7 & 3616.3 & 93.72 & 92.75 & 84.81 \\
\hline 21 & 15429.8 & 7967.3 & 5977.7 & 7888.7 & 3375.0 & 96.62 & 96.98 & 77.61 \\
\hline 24 & 15613.2 & 8144.9 & 6116.1 & 7174.5 & 2819.3 & 98.77 & 99.22 & 70.58 \\
\hline 27 & 15774.6 & 8246.0 & 6164.1 & 6817.8 & 2680.3 & 100.00 & 100.00 & 67.07 \\
\hline 30 & 15922.8 & 8230.4 & 6094.6 & 6504.2 & 2490.0 & 99.81 & 98.87 & 63.99 \\
\hline 33 & 16069.8 & 8021.9 & 5838.7 & 6043.1 & 2172.1 & 97.28 & 94.72 & 59.45 \\
\hline 36 & 16213.7 & 7768.1 & 5593.7 & 5504.8 & 1910.9 & 94.21 & 90.75 & 54.16 \\
\hline 39 & 16349.8 & 7560.1 & 5331.8 & 5078.6 & 1787.5 & 91.68 & 86.50 & 49.96 \\
\hline 42 & 16478.6 & 7413.4 & 5122.1 & 4523.3 & 1557.2 & 89.90 & 83.10 & 44.50 \\
\hline 45 & 16599.8 & 7337.1 & 5004.3 & 4126.6 & 1407.3 & 88.98 & 81.18 & 40.60 \\
\hline 48 & 16716.2 & 7223.7 & 4854.8 & 3813.1 & 1224.5 & 87.60 & 78.76 & 37.51 \\
\hline 51 & 16826.9 & 7055.7 & 4676.6 & 3589.0 & 1045.6 & 85.57 & 75.87 & 35.31 \\
\hline 54 & 16932.1 & 6825.9 & 4513.9 & 3370.5 & 854.0 & 82.78 & 73.23 & 33.16 \\
\hline 57 & 17035.8 & 6773.8 & 4456.0 & 3125.8 & 678.1 & 82.15 & 72.29 & 30.75 \\
\hline 60 & 17139.2 & 6691.8 & 4357.6 & 2883.7 & 540.5 & 81.15 & 70.69 & 28.37 \\
\hline
\end{tabular}


Figure 26A

Percent of Contiguous Stream Width

Middle Fourth of July Creek - JC2

Passage Transect 2 (wide high slope)

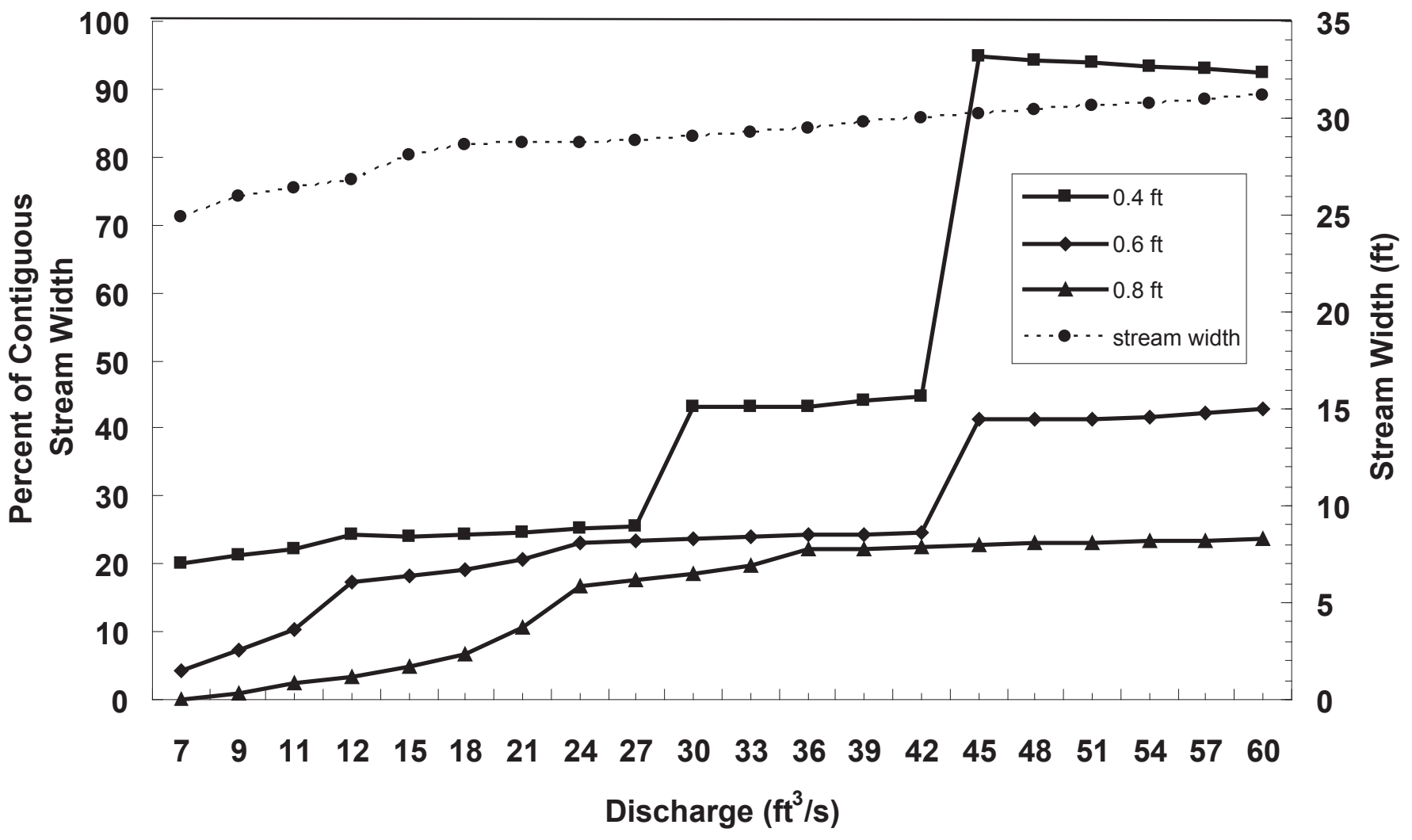


Figure 27A

Percent of Total Stream Width

Middle Fourth of July Creek - JC2

Passage Transect 2 (wide high slope)

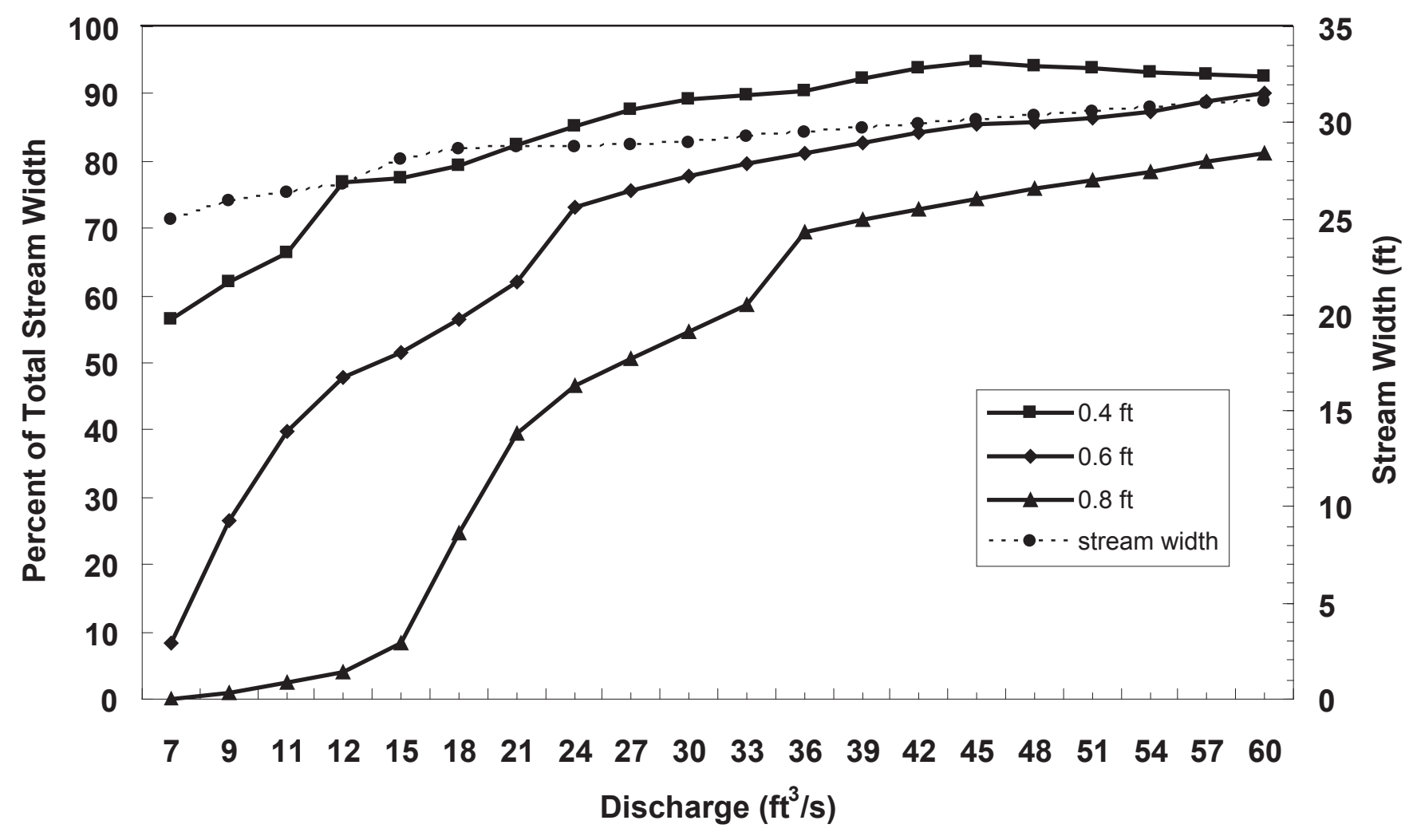


Table 6A. Passage criteria assessment for transect 2 (wide high slope), site JC2, middle Fourth of July Creek, 2003

\begin{tabular}{|c|c|c|c|c|c|}
\hline $\begin{array}{c}\text { Discharge } \\
\left(\mathrm{ft}^{3} / \mathrm{s}\right)\end{array}$ & $\begin{array}{c}\text { Stream width } \\
(\mathrm{ft})\end{array}$ & $\begin{array}{l}\text { Total Stream } \\
\text { Width Greater }\end{array}$ & $\begin{array}{l}\text { Percent Stream } \\
\text { Width Greater } \\
\text { Than } 0.4 \text { ft Depth }\end{array}$ & $\begin{array}{c}\text { Contiguous Stream } \\
\text { Width Greater Than } \\
0.4 \mathrm{ft} \text { Depth }\end{array}$ & $\begin{array}{l}\text { Percent Contiguous } \\
\text { Stream Width Greater } \\
\text { Than } 0.4 \mathrm{ft} \text { Depth }\end{array}$ \\
\hline 7 & 24.94 & 14.11 & 56.60 & 4.98 & 19.99 \\
\hline 9.3 & 25.93 & 16.09 & 62.07 & 5.49 & 21.18 \\
\hline 11 & 26.36 & 17.48 & 66.31 & 5.88 & 22.31 \\
\hline 12.4 & 26.80 & 20.62 & 76.95 & 6.53 & 24.37 \\
\hline 15 & 28.05 & 21.72 & 77.42 & 6.73 & 24.01 \\
\hline 18 & 28.61 & 22.73 & 79.44 & 6.92 & 24.19 \\
\hline 21 & 28.69 & 23.64 & 82.38 & 7.09 & 24.70 \\
\hline 24 & 28.77 & 24.48 & 85.09 & 7.24 & 25.16 \\
\hline 27 & 28.84 & 25.25 & 87.58 & 7.38 & 25.59 \\
\hline 30 & 29.00 & 25.84 & 89.11 & 12.50 & 43.11 \\
\hline 33 & 29.26 & 26.25 & 89.73 & 12.61 & 43.10 \\
\hline 36 & 29.50 & 26.66 & 90.39 & 12.73 & 43.14 \\
\hline 39 & 29.74 & 27.44 & 92.26 & 13.08 & 44.00 \\
\hline 42 & 29.96 & 28.15 & 93.97 & 13.41 & 44.77 \\
\hline 45 & 30.18 & 28.58 & 94.71 & 28.58 & 94.71 \\
\hline 48 & 30.39 & 28.64 & 94.23 & 28.64 & 94.23 \\
\hline 51 & 30.59 & 28.69 & 93.78 & 28.69 & 93.78 \\
\hline 54 & 30.79 & 28.74 & 93.35 & 28.74 & 93.35 \\
\hline 57 & 30.98 & 28.79 & 92.93 & 28.79 & 92.93 \\
\hline 60 & 31.16 & 28.84 & 92.53 & 28.84 & 92.53 \\
\hline $\begin{array}{c}\text { Discharge } \\
\left(\mathrm{ft}^{3} / \mathrm{s}\right)\end{array}$ & $\begin{array}{c}\text { Stream width } \\
\text { (ft) }\end{array}$ & $\begin{array}{l}\text { Total Stream } \\
\text { Width Greater }\end{array}$ & $\begin{array}{l}\text { Percent Stream } \\
\text { Width Greater } \\
\text { Than } 0.6 \text { ft Depth }\end{array}$ & $\begin{array}{c}\text { Contiguous Stream } \\
\text { Width Greater Than } \\
0.6 \mathrm{ft} \text { Depth }\end{array}$ & $\begin{array}{l}\text { Percent Contiguous } \\
\text { Stream Width Greater } \\
\text { Than } \mathbf{0 . 6} \text { ft Depth }\end{array}$ \\
\hline 7 & 24.94 & 2.05 & 8.21 & 1.07 & 4.30 \\
\hline 9.3 & 25.93 & 6.86 & 26.47 & 1.92 & 7.40 \\
\hline 11 & 26.36 & 10.52 & 39.90 & 2.76 & 10.47 \\
\hline 12.4 & 26.80 & 12.82 & 47.83 & 4.68 & 17.46 \\
\hline 15 & 28.05 & 14.49 & 51.67 & 5.07 & 18.09 \\
\hline 18 & 28.61 & 16.18 & 56.55 & 5.52 & 19.28 \\
\hline 21 & 28.69 & 17.79 & 62.00 & 5.97 & 20.81 \\
\hline 24 & 28.77 & 21.02 & 73.07 & 6.61 & 22.96 \\
\hline 27 & 28.84 & 21.78 & 75.54 & 6.75 & 23.40 \\
\hline 30 & 29.00 & 22.53 & 77.68 & 6.88 & 23.74 \\
\hline 33 & 29.26 & 23.27 & 79.52 & 7.02 & 23.99 \\
\hline 36 & 29.50 & 23.95 & 81.20 & 7.14 & 24.22 \\
\hline 39 & 29.74 & 24.64 & 82.86 & 7.27 & 24.44 \\
\hline 42 & 29.96 & 25.28 & 84.38 & 7.38 & 24.65 \\
\hline 45 & 30.18 & 25.78 & 85.44 & 12.49 & 41.38 \\
\hline 48 & 30.39 & 26.12 & 85.96 & 12.57 & 41.38 \\
\hline 51 & 30.59 & 26.44 & 86.43 & 12.66 & 41.38 \\
\hline 54 & 30.79 & 26.90 & 87.39 & 12.84 & 41.70 \\
\hline 57 & 30.98 & 27.53 & 88.86 & 13.13 & 42.37 \\
\hline 60 & 31.16 & 28.12 & 90.23 & 13.40 & 42.99 \\
\hline
\end{tabular}


72 Instream Flow Characterization of Upper Salmon River Basin Streams, Central Idaho, 2003

Table 6A. Passage criteria assessment for transect 2 (wide high slope), site JC2, middle Fourth of July Creek, 2003continued

\begin{tabular}{|c|c|c|c|c|c|}
\hline $\begin{array}{l}\text { Discharge } \\
\left(\mathrm{ft}^{3} / \mathrm{s}\right)\end{array}$ & $\begin{array}{c}\text { Stream width } \\
\text { (ft) }\end{array}$ & $\begin{array}{c}\text { Total Stream } \\
\text { Width Greater } \\
\text { Than } 0.8 \mathrm{ft} \text { Depth }\end{array}$ & $\begin{array}{l}\text { Percent Stream } \\
\text { Width Greater } \\
\text { Than } 0.8 \text { ft Depth }\end{array}$ & $\begin{array}{c}\text { Contiguous Stream } \\
\text { Width Greater Than } \\
0.8 \mathrm{ft} \text { Depth }\end{array}$ & $\begin{array}{l}\text { Percent Contiguous } \\
\text { Stream Width Greater } \\
\text { Than } 0.8 \mathrm{ft} \text { Depth }\end{array}$ \\
\hline 7 & 24.94 & 0.00 & 0.00 & 0.00 & 0.00 \\
\hline 9.3 & 25.93 & 0.27 & 1.02 & 0.27 & 1.02 \\
\hline 11 & 26.36 & 0.66 & 2.52 & 0.66 & 2.52 \\
\hline 12.4 & 26.80 & 1.08 & 4.04 & 0.90 & 3.36 \\
\hline 15 & 28.05 & 2.33 & 8.30 & 1.33 & 4.76 \\
\hline 18 & 28.61 & 7.08 & 24.76 & 1.93 & 6.75 \\
\hline 21 & 28.69 & 11.33 & 39.49 & 3.03 & 10.58 \\
\hline 24 & 28.77 & 13.42 & 46.66 & 4.82 & 16.76 \\
\hline 27 & 28.84 & 14.59 & 50.60 & 5.10 & 17.68 \\
\hline 30 & 29.00 & 15.82 & 54.55 & 5.42 & 18.68 \\
\hline 33 & 29.26 & 17.13 & 58.56 & 5.79 & 19.77 \\
\hline 36 & 29.50 & 20.50 & 69.51 & 6.51 & 22.07 \\
\hline 39 & 29.74 & 21.18 & 71.22 & 6.63 & 22.31 \\
\hline 42 & 29.96 & 21.81 & 72.79 & 6.75 & 22.53 \\
\hline 45 & 30.18 & 22.42 & 74.29 & 6.86 & 22.75 \\
\hline 48 & 30.39 & 23.03 & 75.78 & 6.97 & 22.95 \\
\hline 51 & 30.59 & 23.60 & 77.16 & 7.08 & 23.14 \\
\hline 54 & 30.79 & 24.16 & 78.49 & 7.18 & 23.33 \\
\hline 57 & 30.98 & 24.72 & 79.80 & 7.28 & 23.51 \\
\hline 60 & 31.16 & 25.25 & 81.02 & 7.38 & 23.68 \\
\hline
\end{tabular}




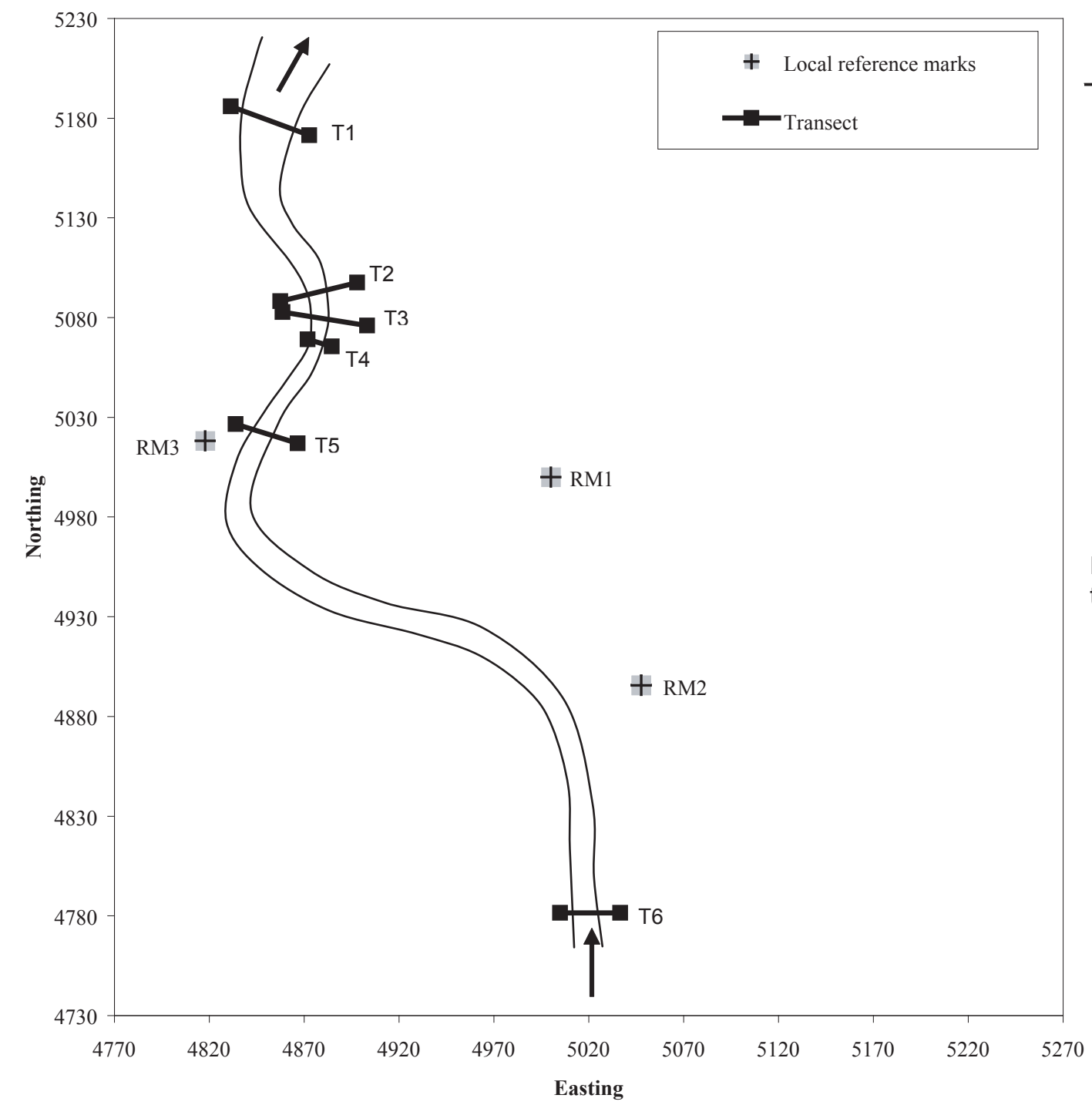

Transect Endpoint Coordinates (NAD 83)

Point Latitude Longitude

LB T1 $114^{\circ} 50^{\prime} 10.69^{\prime \prime} \mathrm{W} \quad 44^{\circ} 11^{\prime} 55.79^{\prime \prime} \mathrm{N}$

RB T1 $114^{\circ} 50^{\prime} 11.33^{\prime \prime} \mathrm{W} \quad 44^{\circ} 11^{\prime} 55.85^{\prime \prime} \mathrm{N}$

LB T2 $114^{\circ} 50^{\prime} 10.21^{\prime \prime} \mathrm{W} \quad 44^{\circ} 11^{\prime} 55.09^{\prime \prime} \mathrm{N}$

RB T2 $114^{\circ} 50^{\prime} 10.76 " \mathrm{~W} \quad 44^{\circ} 11^{\prime} 54.90^{\prime \prime} \mathrm{N}$

LB T3 $114^{\circ} 50^{\prime} 10.10^{\prime \prime} \mathrm{W} \quad 44^{\circ} 11^{\prime} 54.88^{\prime \prime} \mathrm{N}$

RB T3 $114^{\circ} 50^{\prime} 10.74^{\prime \prime} \mathrm{W} \quad 44^{\circ} 11^{\prime} 54.85^{\prime \prime} \mathrm{N}$

LB T4 $114^{\circ} 50^{\prime} 10.35^{\prime \prime} \mathrm{W} \quad 44^{\circ} 11^{\prime} 54.73^{\prime \prime} \mathrm{N}$

RB T4 $114^{\circ} 50^{\prime} 10.73^{\prime \prime} \mathrm{W} \quad 44^{\circ} 1{ }^{\prime} 54.74^{\prime \prime} \mathrm{N}$

LB T5 $114^{\circ} 50^{\prime} 10.52^{\prime \prime} \mathrm{W} \quad 44^{\circ} 11^{\prime} 54.18^{\prime \prime} \mathrm{N}$

RB T5 $114^{\circ} 50^{\prime} 10.99^{\prime \prime} \mathrm{W} \quad 44^{\circ} 11^{\prime} 54.20^{\prime \prime} \mathrm{N}$

LB T6 $114^{\circ} 50^{\prime} 7.74^{\prime \prime} \mathrm{W} \quad 44^{\circ} 11^{\prime} 52.13^{\prime \prime} \mathrm{N}$

RB T6 $114^{\circ} 50^{\prime} 8.19^{\prime \prime} \mathrm{W} \quad 44^{\circ} 11^{\prime} 52.06^{\prime \prime} \mathrm{N}$

For reference only; stream schematic not to scale.

Pla July 
Figure 29A

Lower Fourth of July Creek - JC1

Bull Trout WUA

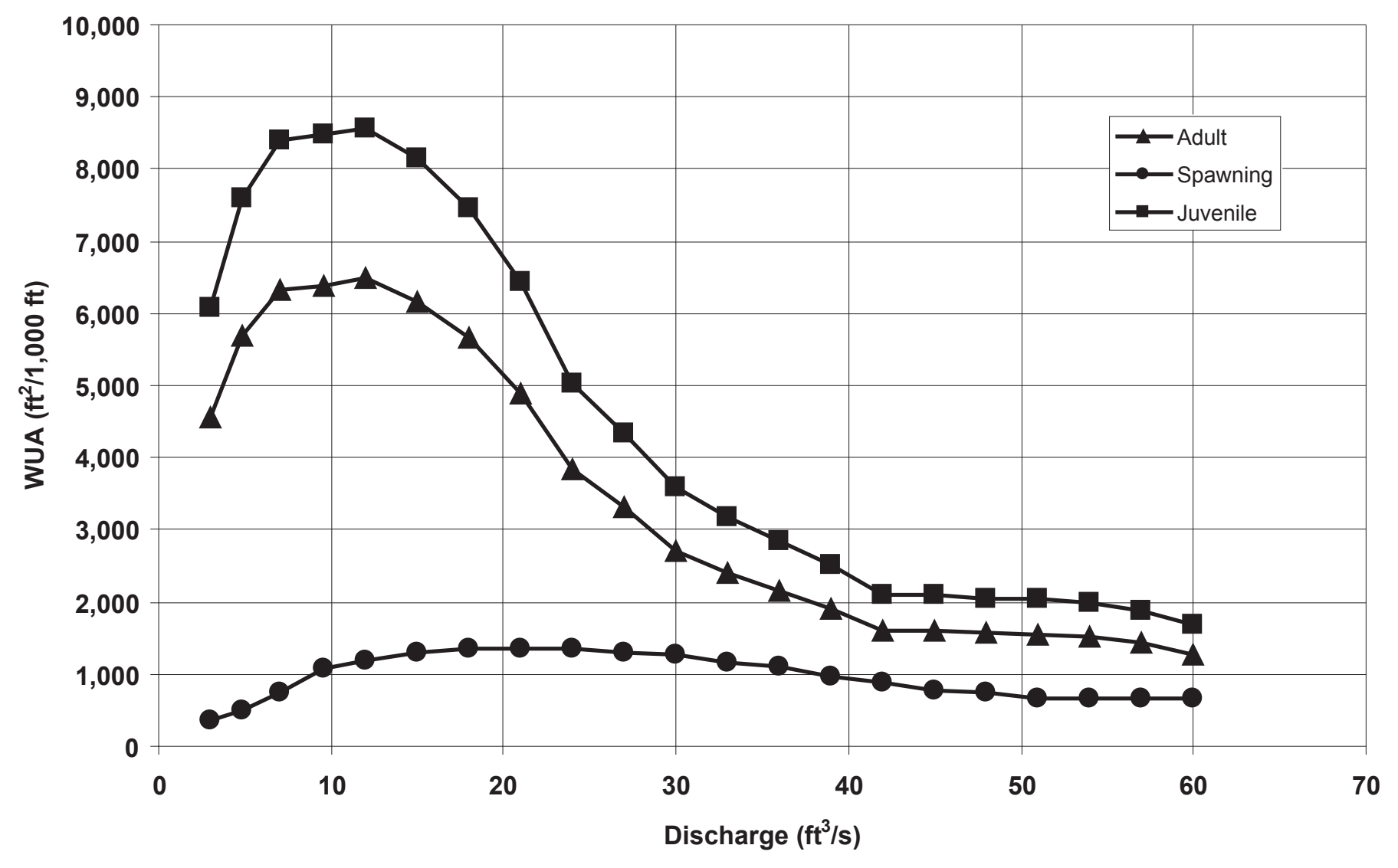


Figure 30A

Lower Fourth of July Creek - JC1

Bull Trout WUA Normalized

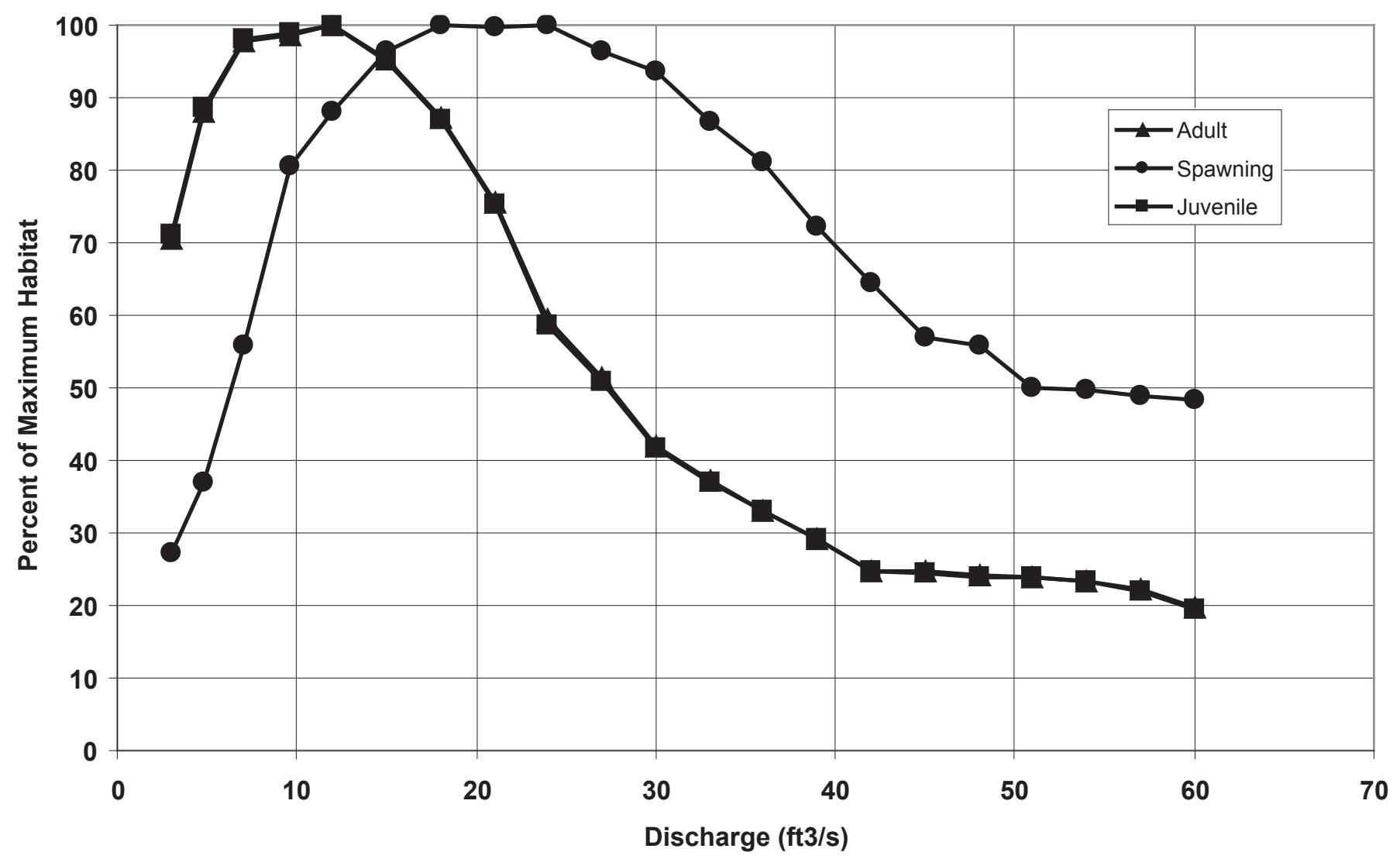


Figure 31A

Lower Fourth of July Creek - JC1

Chinook Salmon WUA

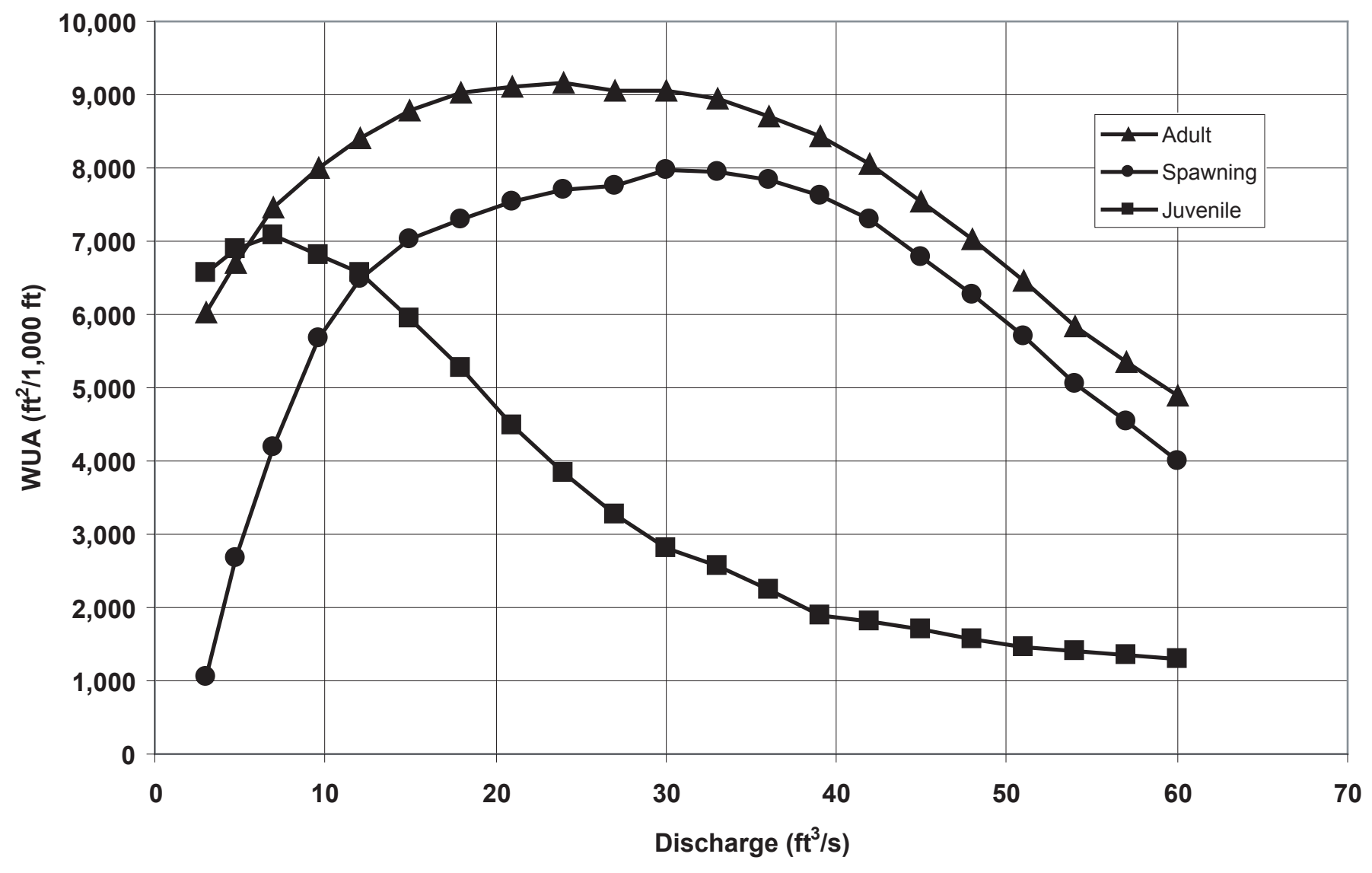


Figure 32A

Lower Fourth of July Creek - JC1

Chinook Salmon WUA Normalized

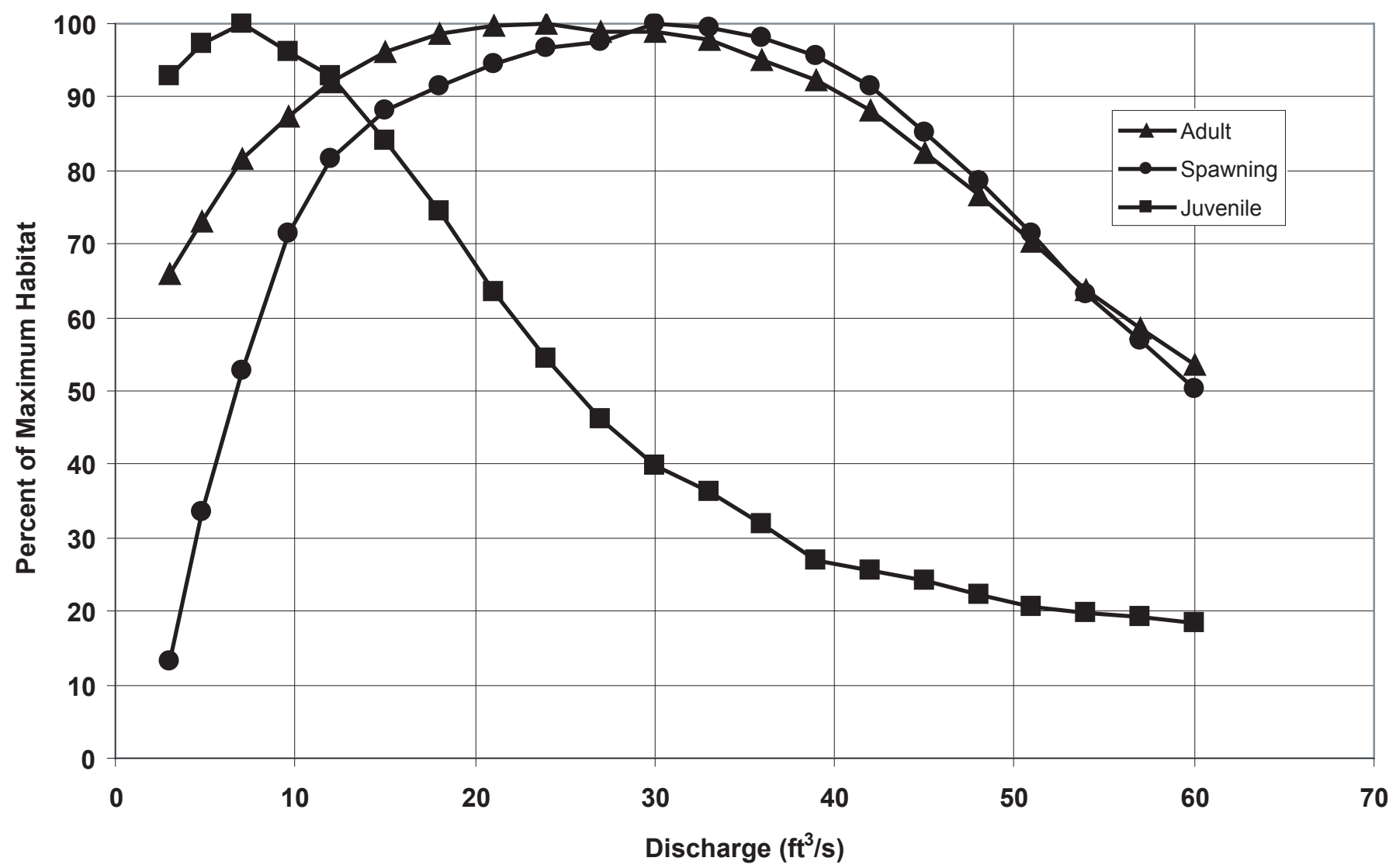


Figure 33A

Lower Fourth of July Creek - JC1

Steelhead WUA

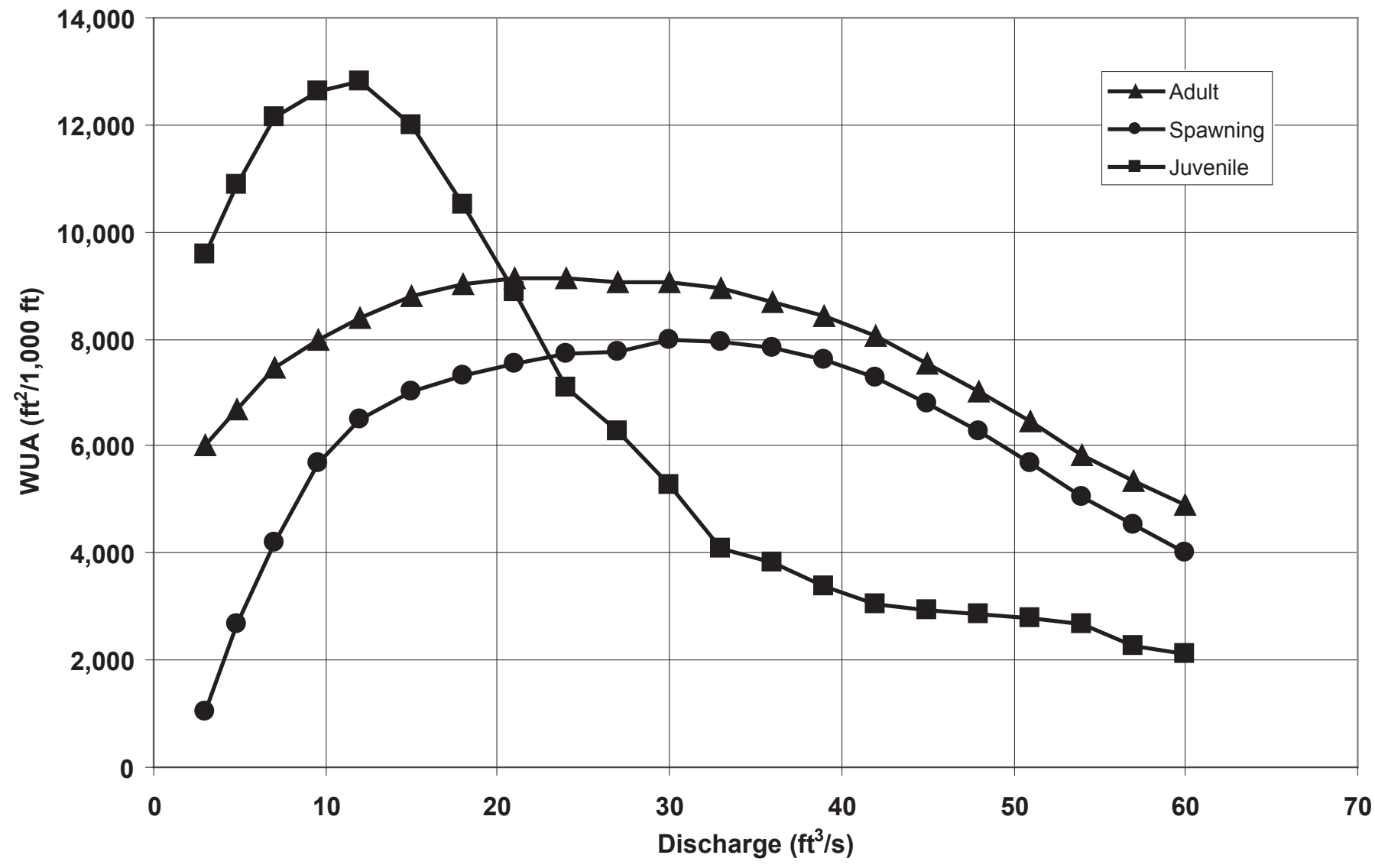

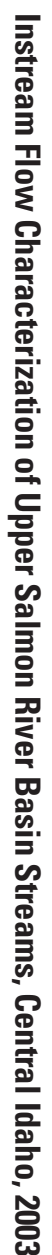


Figure 34A

Lower Fourth of July Creek - JC1

Steelhead WUA Normalized

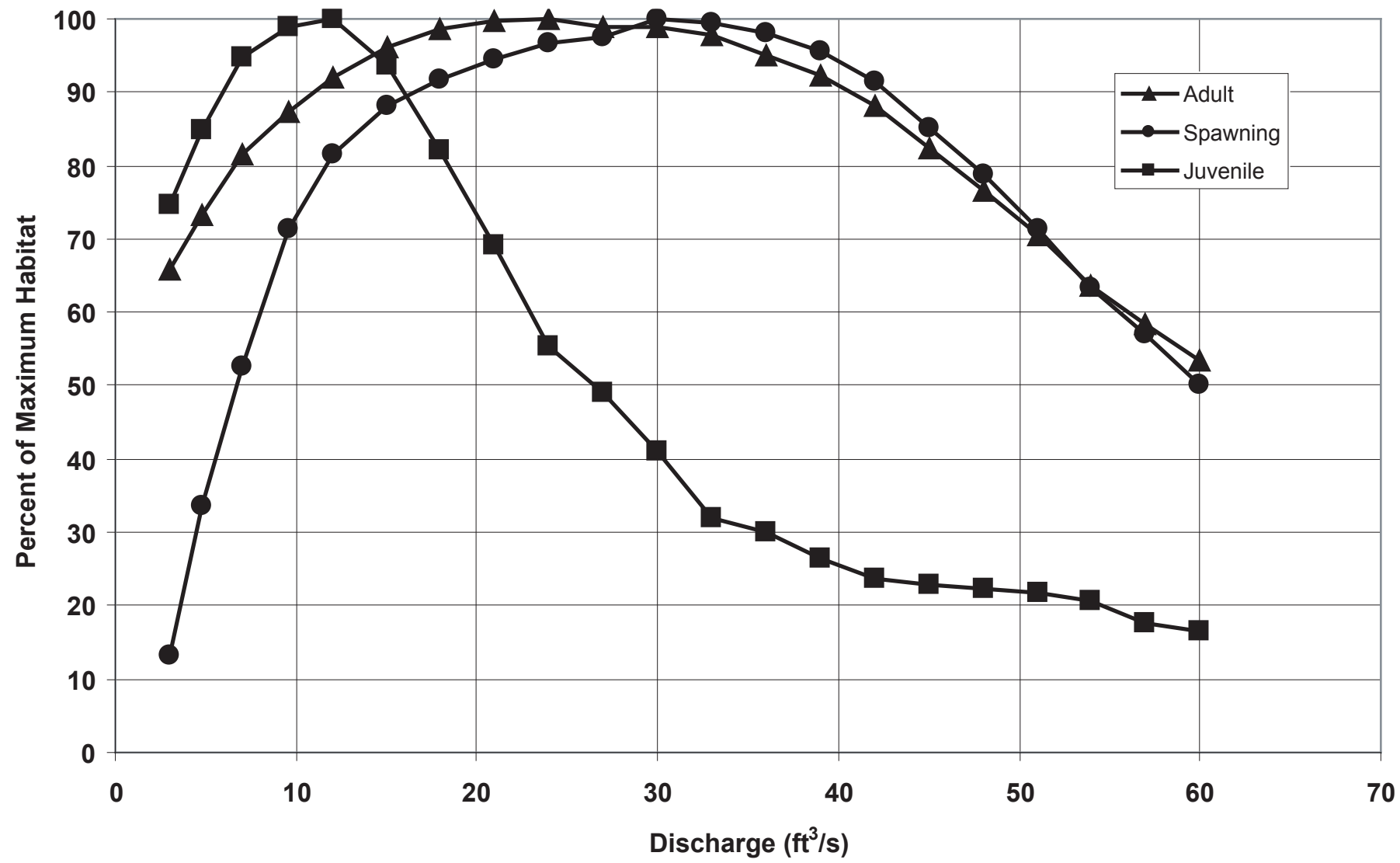


Table 7A. Weighted usable area for bull trout, chinook salmon, steelhead trout life stages, and cover for juvenile life stages, site JC1, lower Fourth of July Creek, 2003

\section{BULL TROUT}

\begin{tabular}{|c|c|c|c|c|c|c|c|c|}
\hline \multirow{2}{*}{$\begin{array}{c}\text { Discharge } \\
\left(\mathrm{ft}^{3} / \mathrm{s}\right)\end{array}$} & \multirow{2}{*}{$\begin{array}{c}\text { Total Area } \\
\quad\left(\mathrm{ft}^{2}\right)\end{array}$} & \multicolumn{4}{|c|}{ Summary of Weighted Usable Area $\left(\mathrm{ft}^{2} / 1000 \mathrm{ft}\right)$} & \multicolumn{3}{|c|}{ Percent of Optimum } \\
\hline & & Adult & Spawning & Juvenile & Cover & Adult & Spawning & Juvenile \\
\hline 3 & 16583.5 & 4567.8 & 368.5 & 6090.1 & 806.7 & 70.51 & 27.26 & 71.01 \\
\hline 4.8 & 17109.9 & 5700.8 & 498.5 & 7595.1 & 940.9 & 88.00 & 36.87 & 88.56 \\
\hline 7 & 17648.8 & 6327.1 & 754.8 & 8410.0 & 952.8 & 97.67 & 55.83 & 98.07 \\
\hline 9.6 & 18162.6 & 6394.9 & 1088.7 & 8479.9 & 953.9 & 98.72 & 80.53 & 98.88 \\
\hline 12 & 19033.3 & 6477.9 & 1190.7 & 8575.8 & 953.2 & 100.00 & 88.07 & 100.00 \\
\hline 15 & 19319.5 & 6172.5 & 1301.9 & 8157.2 & 890.8 & 95.28 & 96.29 & 95.12 \\
\hline 18 & 19469.1 & 5659.1 & 1352.0 & 7465.5 & 835.0 & 87.36 & 100.00 & 87.05 \\
\hline 21 & 19579.9 & 4899.6 & 1347.7 & 6446.8 & 757.1 & 75.64 & 99.69 & 75.17 \\
\hline 24 & 19679.4 & 3843.0 & 1350.7 & 5030.9 & 577.7 & 59.32 & 99.91 & 58.66 \\
\hline 27 & 19772.1 & 3324.3 & 1302.1 & 4349.2 & 524.8 & 51.32 & 96.31 & 50.71 \\
\hline 30 & 20007.9 & 2718.9 & 1266.0 & 3582.0 & 415.4 & 41.97 & 93.64 & 41.77 \\
\hline 33 & 20049.2 & 2405.2 & 1171.8 & 3169.6 & 410.8 & 37.13 & 86.68 & 36.96 \\
\hline 36 & 20087.3 & 2140.9 & 1095.0 & 2832.5 & 404.7 & 33.05 & 81.00 & 33.03 \\
\hline 39 & 20124.1 & 1897.0 & 978.0 & 2507.9 & 397.3 & 29.28 & 72.34 & 29.24 \\
\hline 42 & 20159.3 & 1601.5 & 872.0 & 2108.8 & 388.6 & 24.72 & 64.50 & 24.59 \\
\hline 45 & 20193.9 & 1593.3 & 770.7 & 2096.0 & 378.7 & 24.60 & 57.00 & 24.44 \\
\hline 48 & 20224.9 & 1561.1 & 754.1 & 2051.6 & 365.7 & 24.10 & 55.78 & 23.92 \\
\hline 51 & 20255.8 & 1555.3 & 676.5 & 2044.1 & 347.4 & 24.01 & 50.04 & 23.84 \\
\hline 54 & 20285.0 & 1517.8 & 672.7 & 1994.9 & 323.1 & 23.43 & 49.76 & 23.26 \\
\hline 57 & 20313.82 & 1440.96 & 662.8 & 1890.2 & 307.3 & 22.24 & 49.02 & 22.04 \\
\hline 60 & 20343.22 & 1282.83 & 652.4 & 1676.0 & 281.8 & 19.80 & 48.26 & 19.54 \\
\hline
\end{tabular}

\section{CHINOOK SALMON}

\begin{tabular}{|c|c|c|c|c|c|c|c|c|}
\hline \multirow{2}{*}{$\begin{array}{c}\text { Discharge } \\
\left(\mathrm{ft}^{3} / \mathrm{s}\right)\end{array}$} & \multirow{2}{*}{$\begin{array}{c}\text { Total Area } \\
\left(\mathrm{ft}^{2}\right)\end{array}$} & \multicolumn{4}{|c|}{ Summary of Weighted Usable Area ( $\left.\mathrm{ft}^{2} / 1000 \mathrm{ft}\right)$} & \multicolumn{3}{|c|}{ Percent of Optimum } \\
\hline & & Adult & Spawning & Juvenile & Cover & Adult & Spawning & Juvenile \\
\hline 3 & 16583.5 & 6033.3 & 1057.6 & 6563.3 & 752.2 & 65.93 & 13.27 & 92.78 \\
\hline 4.8 & 17109.9 & 6696.1 & 2676.2 & 6879.6 & 754.6 & 73.18 & 33.58 & 97.25 \\
\hline 7 & 17648.8 & 7466.2 & 4199.8 & 7074.2 & 753.8 & 81.59 & 52.70 & 100.00 \\
\hline 9.6 & 18162.6 & 7996.1 & 5683.1 & 6801.2 & 710.3 & 87.38 & 71.31 & 96.14 \\
\hline 12 & 19033.3 & 8409.7 & 6494.6 & 6566.2 & 655.9 & 91.90 & 81.49 & 92.82 \\
\hline 15 & 19319.5 & 8788.2 & 7027.7 & 5948.3 & 566.4 & 96.04 & 88.18 & 84.08 \\
\hline 18 & 19469.1 & 9014.2 & 7300.4 & 5257.4 & 480.4 & 98.51 & 91.60 & 74.32 \\
\hline 21 & 19579.9 & 9119.1 & 7528.2 & 4494.2 & 427.8 & 99.66 & 94.46 & 63.53 \\
\hline 24 & 19679.4 & 9150.5 & 7713.4 & 3840.6 & 341.7 & 100.00 & 96.78 & 54.29 \\
\hline 27 & 19772.1 & 9053.5 & 7762.0 & 3265.3 & 278.4 & 98.94 & 97.39 & 46.16 \\
\hline 30 & 20007.9 & 9057.5 & 7969.9 & 2822.1 & 266.8 & 98.98 & 100.00 & 39.89 \\
\hline 33 & 20049.2 & 8941.2 & 7933.9 & 2567.9 & 254.1 & 97.71 & 99.55 & 36.30 \\
\hline 36 & 20087.3 & 8705.4 & 7826.5 & 2255.4 & 234.2 & 95.14 & 98.20 & 31.88 \\
\hline 39 & 20124.1 & 8439.3 & 7628.4 & 1897.3 & 221.8 & 92.23 & 95.71 & 26.82 \\
\hline 42 & 20159.3 & 8064.0 & 7286.0 & 1797.8 & 211.9 & 88.13 & 91.42 & 25.41 \\
\hline 45 & 20193.9 & 7543.0 & 6787.7 & 1713.4 & 201.6 & 82.43 & 85.17 & 24.22 \\
\hline 48 & 20224.9 & 7015.0 & 6270.1 & 1577.8 & 190.3 & 76.66 & 78.67 & 22.30 \\
\hline 51 & 20255.8 & 6448.0 & 5697.1 & 1451.6 & 181.1 & 70.47 & 71.48 & 20.52 \\
\hline 54 & 20285.0 & 5826.4 & 5041.0 & 1408.1 & 170.2 & 63.67 & 63.25 & 19.90 \\
\hline 57 & 20313.82 & 5351.06 & 4535.1 & 1355.26 & 160.16 & 58.48 & 56.90 & 19.16 \\
\hline 60 & 20343.22 & 4890.44 & 3996.51 & 1303.7 & 151.45 & 53.44 & 50.15 & 18.43 \\
\hline
\end{tabular}


Table 7A. Weighted usable area for bull trout, chinook salmon, steelhead trout life stages, and cover for juvenile life stages, site JC1, lower Fourth of July Creek, 2003 — Continued

\section{STEELHEAD}

\begin{tabular}{|c|c|c|c|c|c|c|c|c|}
\hline \multirow{2}{*}{$\begin{array}{c}\text { Discharge } \\
\qquad\left(\mathrm{ft}^{3} / \mathrm{s}\right)\end{array}$} & \multirow{2}{*}{$\begin{array}{c}\text { Total Area } \\
\left(\mathrm{ft}^{2}\right)\end{array}$} & \multicolumn{4}{|c|}{ Summary of Weighted Usable Area $\left(\mathrm{ft}^{2} / 1000 \mathrm{ft}\right)$} & \multicolumn{3}{|c|}{ Percent of Optimum } \\
\hline & & Adult & Spawning & Juvenile & Cover & Adult & Spawning & Juvenile \\
\hline 3 & 16583.5 & 6033.3 & 1057.6 & 9568.1 & 1089.4 & 65.93 & 13.27 & 74.74 \\
\hline 4.8 & 17109.9 & 6696.1 & 2676.2 & 10863.3 & 1201.0 & 73.18 & 33.58 & 84.85 \\
\hline 7 & 17648.8 & 7466.2 & 4199.8 & 12139.3 & 1301.5 & 81.59 & 52.70 & 94.82 \\
\hline 9.6 & 18162.6 & 7996.1 & 5683.1 & 12643.8 & 1327.3 & 87.38 & 71.31 & 98.76 \\
\hline 12 & 19033.3 & 8409.7 & 6494.6 & 12802.3 & 1275.2 & 91.90 & 81.49 & 100.00 \\
\hline 15 & 19319.5 & 8788.2 & 7027.7 & 12002.1 & 1063.7 & 96.04 & 88.18 & 93.75 \\
\hline 18 & 19469.1 & 9014.2 & 7300.4 & 10508.8 & 873.9 & 98.51 & 91.60 & 82.09 \\
\hline 21 & 19579.9 & 9119.1 & 7528.2 & 8860.0 & 637.6 & 99.66 & 94.46 & 69.21 \\
\hline 24 & 19679.4 & 9150.5 & 7713.4 & 7096.1 & 519.4 & 100.00 & 96.78 & 55.43 \\
\hline 27 & 19772.1 & 9053.5 & 7762.0 & 6284.9 & 493.3 & 98.94 & 97.39 & 49.09 \\
\hline 30 & 20007.9 & 9057.5 & 7969.9 & 5263.2 & 472.2 & 98.98 & 100.00 & 41.11 \\
\hline 33 & 20049.2 & 8941.2 & 7933.9 & 4090.2 & 467.2 & 97.71 & 99.55 & 31.95 \\
\hline 36 & 20087.3 & 8705.4 & 7826.5 & 3838.7 & 461.3 & 95.14 & 98.20 & 29.98 \\
\hline 39 & 20124.1 & 8439.3 & 7628.4 & 3393.6 & 450.6 & 92.23 & 95.71 & 26.51 \\
\hline 42 & 20159.3 & 8064.0 & 7286.0 & 3049.5 & 437.3 & 88.13 & 91.42 & 23.82 \\
\hline 45 & 20193.9 & 7543.0 & 6787.7 & 2940.9 & 422.4 & 82.43 & 85.17 & 22.97 \\
\hline 48 & 20224.9 & 7015.0 & 6270.1 & 2848.9 & 404.1 & 76.66 & 78.67 & 22.25 \\
\hline 51 & 20255.8 & 6448.0 & 5697.1 & 2782.3 & 382.4 & 70.47 & 71.48 & 21.73 \\
\hline 54 & 20285.0 & 5826.4 & 5041.0 & 2658.6 & 354.0 & 63.67 & 63.25 & 20.77 \\
\hline 57 & 20313.8 & 5351.1 & 4535.1 & 2255.6 & 305.0 & 58.48 & 56.90 & 17.62 \\
\hline 60 & 20343.2 & 4890.4 & 3996.5 & 2114.6 & 216.7 & 53.44 & 50.15 & 16.52 \\
\hline
\end{tabular}


Figure 35A

Percent of Contiguous Stream Width

Lower Fourth of July Creek - JC1

Passage Transect 1 (wide low slope)

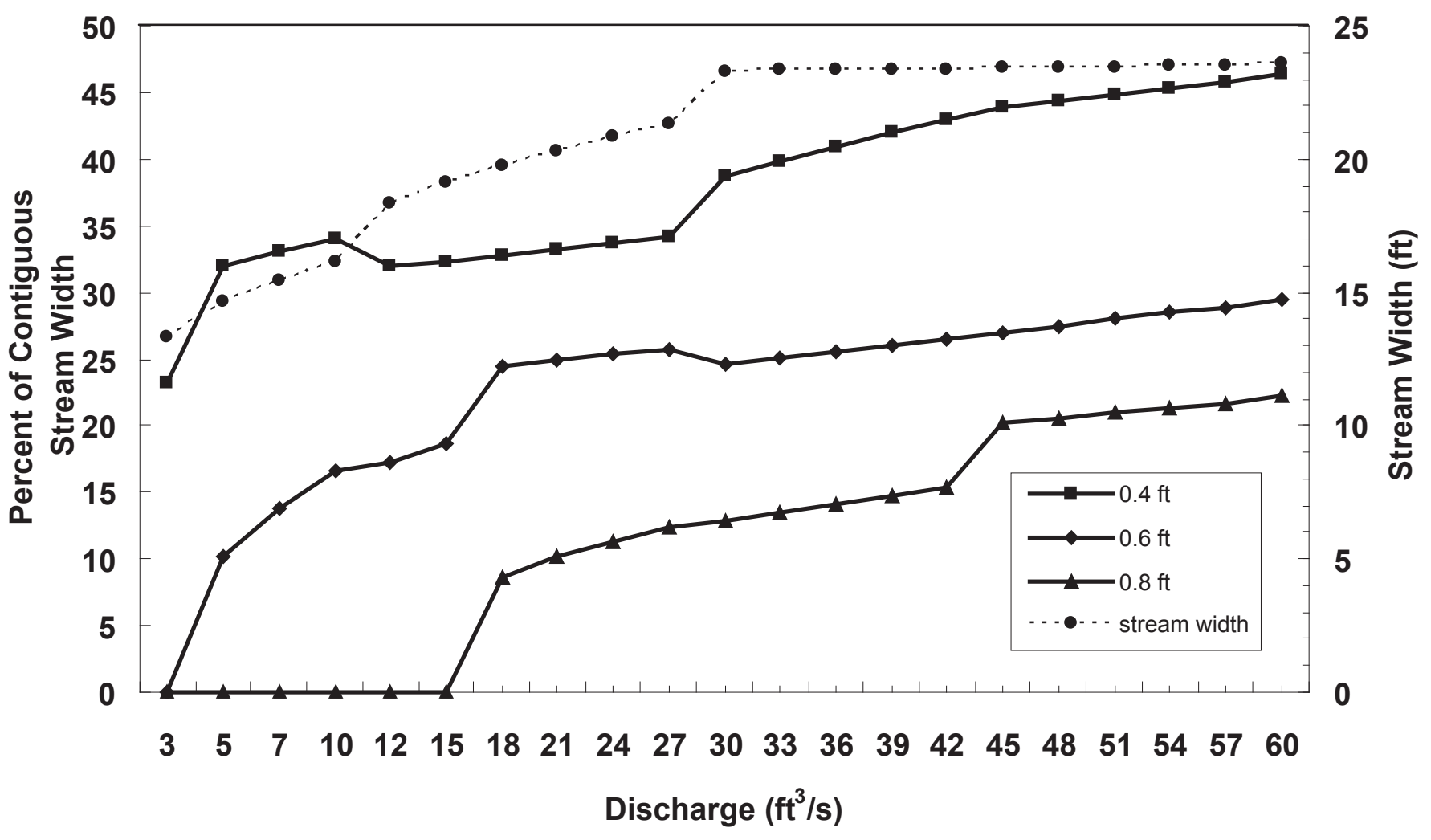

Discharge $\left(\mathrm{ft}^{3} / \mathrm{s}\right)$ 
Figure 36A

Percent of Total Stream Width

Lower Fourth of July Creek - JC1

Passage Transect 1 (wide low slope)

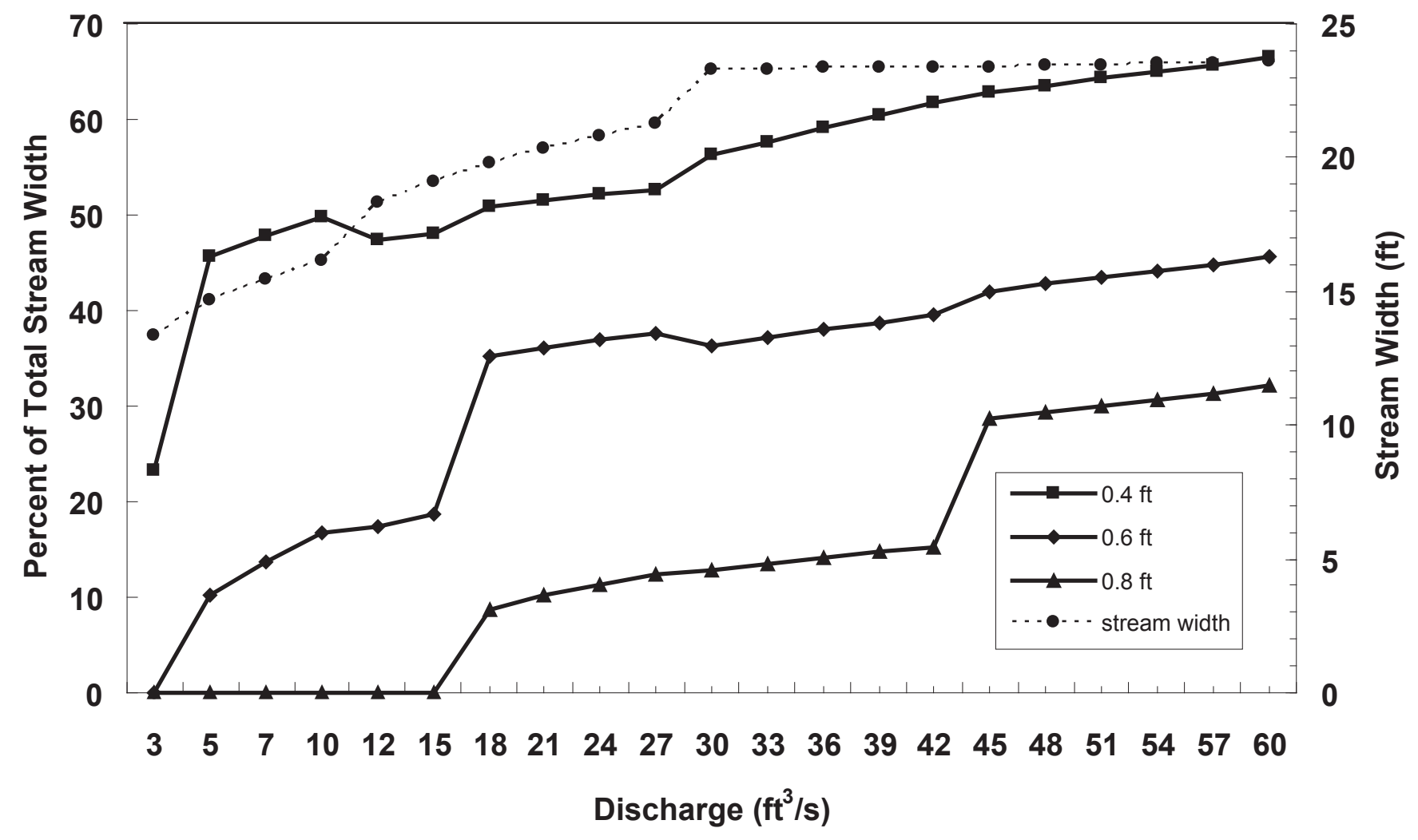


Table 8A. Passage criteria assessment for transect 1 (wide low slope), site JC1, lower Fourth of July Creek, 2003

\begin{tabular}{|c|c|c|c|c|c|}
\hline $\begin{array}{c}\text { Discharge } \\
\left(\mathrm{ft}^{3} / \mathrm{s}\right)\end{array}$ & $\begin{array}{c}\text { Stream width } \\
\text { (ft) }\end{array}$ & $\begin{array}{l}\text { Total Stream } \\
\text { Width Greater } \\
\text { Than } 0.4 \text { ft depth }\end{array}$ & $\begin{array}{l}\text { Percent Stream } \\
\text { Width Greater } \\
\text { Than } 0.4 \text { ft Depth }\end{array}$ & $\begin{array}{c}\text { Contiguous Stream } \\
\text { Width Greater Than } \\
0.4 \mathrm{ft} \text { Depth }\end{array}$ & $\begin{array}{l}\text { Percent Contiguous } \\
\text { Stream Width Greater } \\
\text { Than } 0.4 \mathrm{ft} \text { Depth }\end{array}$ \\
\hline 3 & 13.34 & 3.09 & 23.20 & 3.09 & 23.20 \\
\hline 4.8 & 14.68 & 6.70 & 45.67 & 4.70 & 32.03 \\
\hline 7 & 15.45 & 7.40 & 47.88 & 5.11 & 33.10 \\
\hline 9.6 & 16.18 & 8.05 & 49.75 & 5.50 & 33.99 \\
\hline 12 & 18.36 & 8.70 & 47.37 & 5.88 & 32.05 \\
\hline 15 & 19.12 & 9.20 & 48.13 & 6.18 & 32.34 \\
\hline 18 & 19.77 & 10.06 & 50.91 & 6.48 & 32.78 \\
\hline 21 & 20.33 & 10.49 & 51.58 & 6.77 & 33.29 \\
\hline 24 & 20.82 & 10.86 & 52.15 & 7.02 & 33.73 \\
\hline 27 & 21.28 & 11.21 & 52.66 & 7.26 & 34.11 \\
\hline 30 & 23.30 & 13.11 & 56.27 & 9.01 & 38.66 \\
\hline 33 & 23.32 & 13.46 & 57.71 & 9.28 & 39.80 \\
\hline 36 & 23.34 & 13.79 & 59.09 & 9.55 & 40.89 \\
\hline 39 & 23.36 & 14.11 & 60.40 & 9.80 & 41.93 \\
\hline 42 & 23.38 & 14.42 & 61.65 & 10.04 & 42.93 \\
\hline 45 & 23.40 & 14.70 & 62.81 & 10.26 & 43.83 \\
\hline 48 & 23.44 & 14.89 & 63.54 & 10.39 & 44.33 \\
\hline 51 & 23.47 & 15.08 & 64.24 & 10.52 & 44.82 \\
\hline 54 & 23.50 & 15.25 & 64.92 & 10.64 & 45.29 \\
\hline 57 & 23.52 & 15.43 & 65.57 & 10.76 & 45.74 \\
\hline 60 & 23.56 & 15.67 & 66.49 & 10.93 & 46.37 \\
\hline $\begin{array}{c}\text { Discharge } \\
\left(\mathrm{ft}^{3} / \mathrm{s}\right)\end{array}$ & $\begin{array}{c}\text { Stream width } \\
\text { (ft) }\end{array}$ & $\begin{array}{c}\text { Total Stream } \\
\text { Width Greater } \\
\text { Than } 0.6 \text { ft Depth }\end{array}$ & $\begin{array}{l}\text { Percent Stream } \\
\text { Width Greater } \\
\text { Than } 0.6 \text { ft Depth }\end{array}$ & $\begin{array}{c}\text { Contiguous Stream } \\
\text { Width Greater Than } \\
0.6 \mathrm{ft} \text { Depth }\end{array}$ & $\begin{array}{l}\text { Percent Contiguous } \\
\text { Stream Width Greater } \\
\text { Than } \mathbf{0 . 6} \mathrm{ft} \text { Depth }\end{array}$ \\
\hline 3 & 13.34 & 0.00 & 0.00 & 0.00 & 0.00 \\
\hline 4.8 & 14.68 & 1.50 & 10.24 & 1.50 & 10.24 \\
\hline 7 & 15.45 & 2.12 & 13.73 & 2.12 & 13.73 \\
\hline 9.6 & 16.18 & 2.70 & 16.69 & 2.70 & 16.69 \\
\hline 12 & 18.36 & 3.18 & 17.32 & 3.18 & 17.32 \\
\hline 15 & 19.12 & 3.55 & 18.59 & 3.55 & 18.59 \\
\hline 18 & 19.77 & 6.94 & 35.12 & 4.84 & 24.50 \\
\hline 21 & 20.33 & 7.33 & 36.07 & 5.07 & 24.96 \\
\hline 24 & 20.82 & 7.67 & 36.86 & 5.28 & 25.35 \\
\hline 27 & 21.28 & 7.99 & 37.57 & 5.47 & 25.69 \\
\hline 30 & 23.30 & 8.44 & 36.24 & 5.73 & 24.61 \\
\hline 33 & 23.32 & 8.66 & 37.12 & 5.86 & 25.13 \\
\hline 36 & 23.34 & 8.86 & 37.96 & 5.98 & 25.62 \\
\hline 39 & 23.36 & 9.06 & 38.76 & 6.10 & 26.09 \\
\hline 42 & 23.38 & 9.24 & 39.53 & 6.21 & 26.54 \\
\hline 45 & 23.40 & 9.83 & 41.98 & 6.32 & 26.99 \\
\hline 48 & 23.44 & 10.01 & 42.72 & 6.44 & 27.50 \\
\hline 51 & 23.47 & 10.19 & 43.43 & 6.57 & 27.98 \\
\hline 54 & 23.50 & 10.37 & 44.12 & 6.69 & 28.45 \\
\hline 57 & 23.52 & 10.53 & 44.77 & 6.80 & 28.90 \\
\hline 60 & 23.56 & 10.77 & 45.69 & 6.96 & 29.54 \\
\hline
\end{tabular}


Table 8A. Passage criteria assessment for transect 1 (wide low slope), site JC1, lower Fourth of July Creek, 2003—Continued

\begin{tabular}{|c|c|c|c|c|c|}
\hline $\begin{array}{c}\text { Discharge } \\
\left(\mathrm{ft}^{3} / \mathrm{s}\right)\end{array}$ & $\begin{array}{c}\text { Stream width } \\
\text { (ft) }\end{array}$ & $\begin{array}{c}\text { Total Stream } \\
\text { Width Greater } \\
\text { Than } 0.8 \mathrm{ft} \text { Depth }\end{array}$ & $\begin{array}{l}\text { Percent Stream } \\
\text { Width Greater } \\
\text { Than } 0.8 \mathrm{ft} \text { Depth }\end{array}$ & $\begin{array}{c}\text { Contiguous Stream } \\
\text { Width Greater Than } \\
0.8 \mathrm{ft} \text { Depth }\end{array}$ & $\begin{array}{l}\text { Percent Contiguous } \\
\text { Stream Width Greater } \\
\text { Than } \mathbf{0 . 8} \mathrm{ft} \text { Depth }\end{array}$ \\
\hline 3 & 13.34 & 0.00 & 0.00 & 0.00 & 0.00 \\
\hline 4.8 & 14.68 & 0.00 & 0.00 & 0.00 & 0.00 \\
\hline 7 & 15.45 & 0.00 & 0.00 & 0.00 & 0.00 \\
\hline 9.6 & 16.18 & 0.00 & 0.00 & 0.00 & 0.00 \\
\hline 12 & 18.36 & 0.00 & 0.00 & 0.00 & 0.00 \\
\hline 15 & 19.12 & 0.00 & 0.00 & 0.00 & 0.00 \\
\hline 18 & 19.77 & 1.72 & 8.68 & 1.72 & 8.68 \\
\hline 21 & 20.33 & 2.06 & 10.14 & 2.06 & 10.14 \\
\hline 24 & 20.82 & 2.37 & 11.36 & 2.37 & 11.36 \\
\hline 27 & 21.28 & 2.65 & 12.45 & 2.65 & 12.45 \\
\hline 30 & 23.30 & 2.99 & 12.84 & 2.99 & 12.84 \\
\hline 33 & 23.32 & 3.15 & 13.51 & 3.15 & 13.51 \\
\hline 36 & 23.34 & 3.30 & 14.14 & 3.30 & 14.14 \\
\hline 39 & 23.36 & 3.45 & 14.75 & 3.45 & 14.75 \\
\hline 42 & 23.38 & 3.58 & 15.33 & 3.58 & 15.33 \\
\hline 45 & 23.40 & 6.72 & 28.73 & 4.71 & 20.14 \\
\hline 48 & 23.44 & 6.89 & 29.42 & 4.82 & 20.55 \\
\hline 51 & 23.47 & 7.06 & 30.09 & 4.91 & 20.94 \\
\hline 54 & 23.50 & 7.22 & 30.73 & 5.01 & 21.32 \\
\hline 57 & 23.52 & 7.37 & 31.35 & 5.10 & 21.68 \\
\hline 60 & 23.56 & 7.59 & 32.21 & 5.23 & 22.19 \\
\hline
\end{tabular}


Figure 37A

Percent of Contiguous Stream Width

Lower Fourth of July Creek - JC1

Passage Transect 5 (wide high slope)

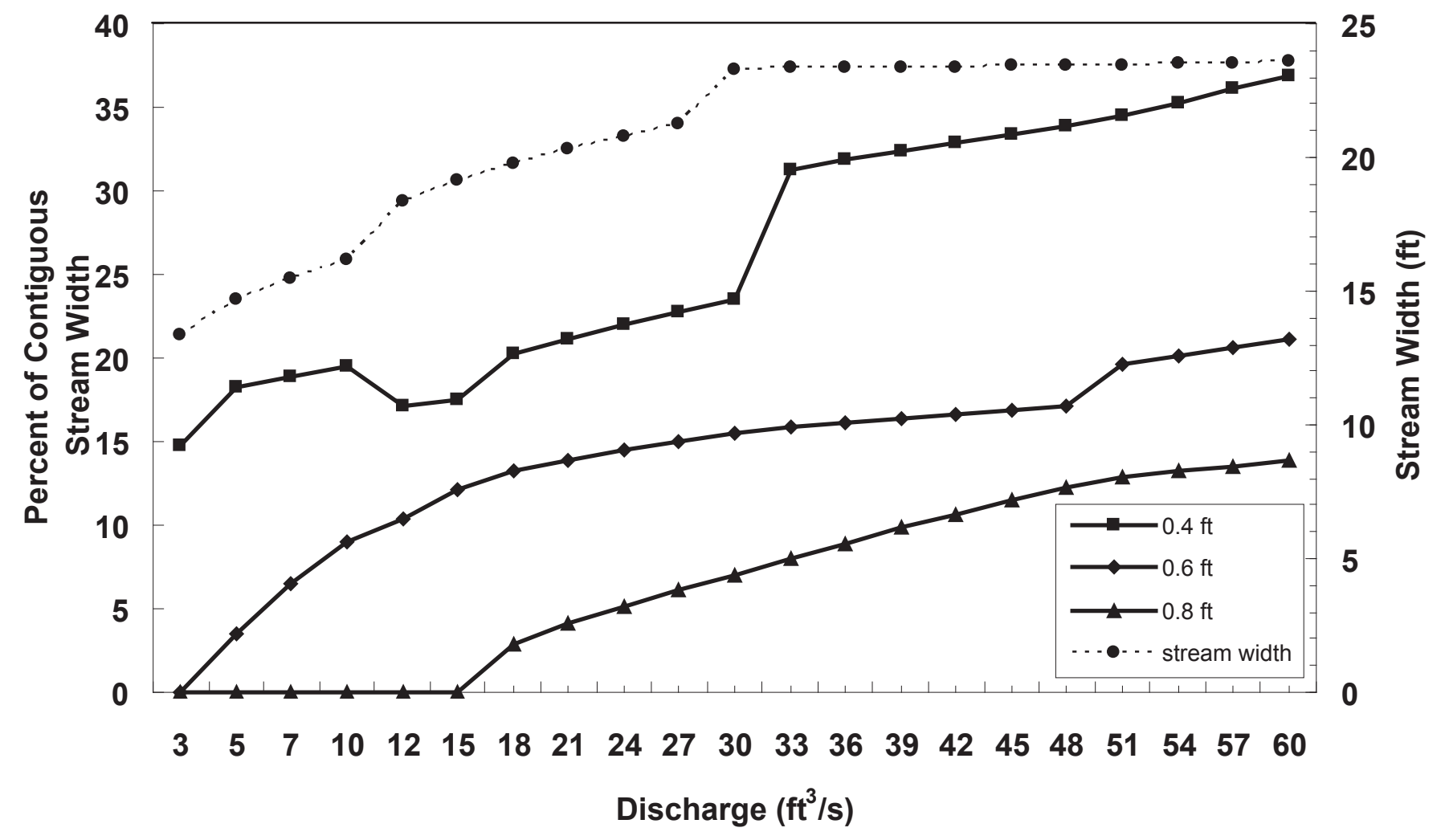

Discharge $\left(\mathrm{ft}^{3} / \mathrm{s}\right)$ 
Figure 38A

Percent of Total Stream Width

Lower Fourth of July Creek - JC1

Passage Transect 5 (wide high slope)

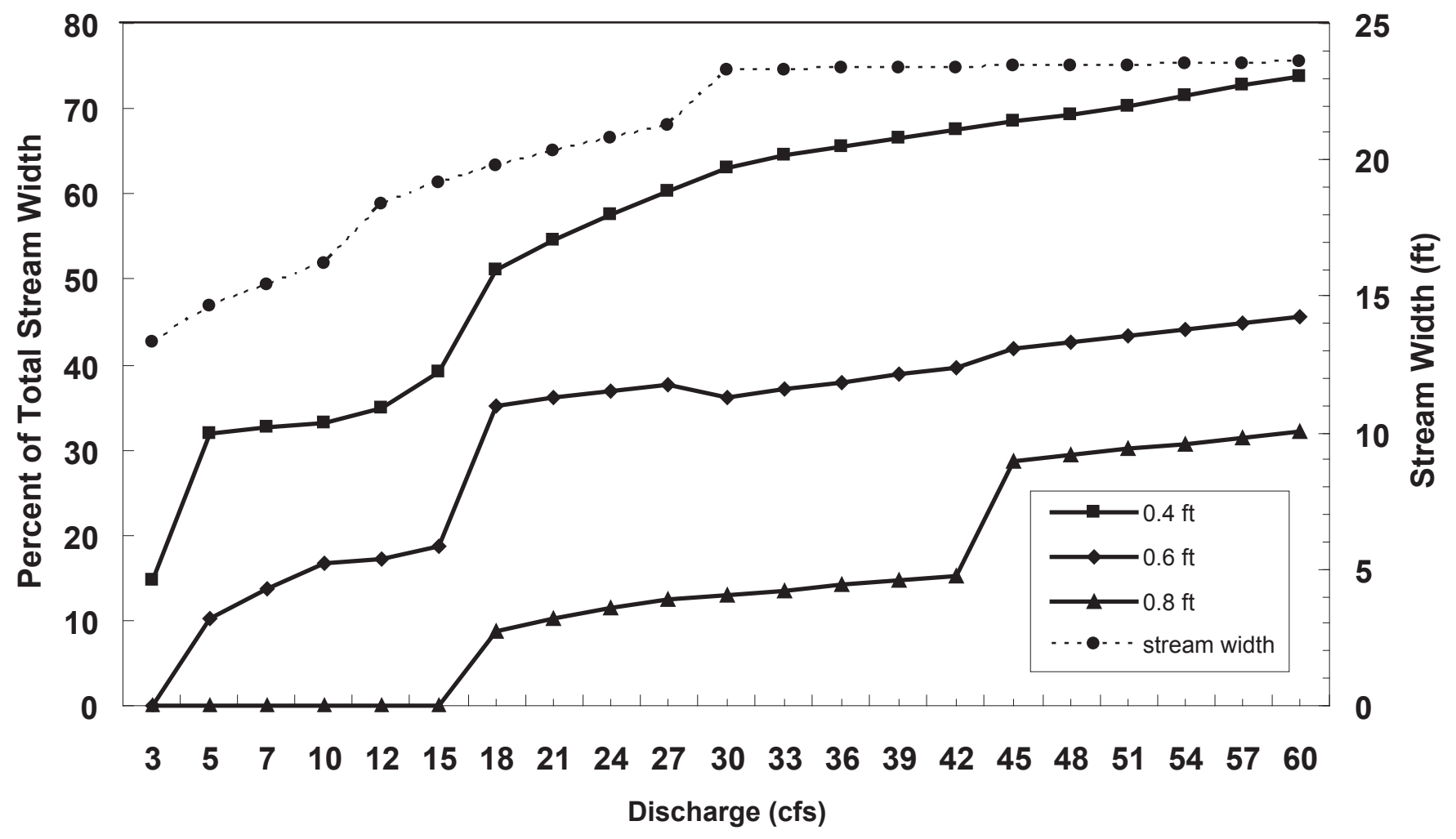


Table 9A. Passage criteria assessment for transect 5 (wide high slope), site JC1, lower Fourth of July Creek, 2003

\begin{tabular}{|c|c|c|c|c|c|}
\hline $\begin{array}{c}\text { Discharge } \\
\left(\mathrm{ft}^{3} / \mathrm{s}\right)\end{array}$ & $\begin{array}{c}\text { Stream width } \\
(\mathrm{ft})\end{array}$ & $\begin{array}{l}\text { Total Stream } \\
\text { Width Greater } \\
\text { Than } 0.4 \mathrm{ft} \text { depth }\end{array}$ & $\begin{array}{l}\text { Percent Stream } \\
\text { Width Greater } \\
\text { Than } 0.4 \text { ft Depth }\end{array}$ & $\begin{array}{c}\text { Contiguous Stream } \\
\text { Width Greater Than } \\
0.4 \mathrm{ft} \text { Depth }\end{array}$ & $\begin{array}{l}\text { Percent Contiguous } \\
\text { Stream Width Greater } \\
\text { Than } 0.4 \mathrm{ft} \text { Depth }\end{array}$ \\
\hline 3 & 16.69 & 2.46 & 14.76 & 2.46 & 14.76 \\
\hline 4.8 & 17.59 & 5.60 & 31.86 & 3.20 & 18.21 \\
\hline 7 & 18.83 & 6.13 & 32.56 & 3.56 & 18.93 \\
\hline 9.6 & 19.98 & 6.62 & 33.14 & 3.90 & 19.52 \\
\hline 12 & 24.06 & 8.39 & 34.88 & 4.12 & 17.14 \\
\hline 15 & 24.44 & 9.55 & 39.07 & 4.27 & 17.47 \\
\hline 18 & 24.68 & 12.64 & 51.20 & 5.00 & 20.24 \\
\hline 21 & 24.77 & 13.51 & 54.56 & 5.24 & 21.16 \\
\hline 24 & 24.85 & 14.32 & 57.63 & 5.46 & 21.99 \\
\hline 27 & 24.92 & 15.06 & 60.43 & 5.67 & 22.75 \\
\hline 30 & 24.99 & 15.76 & 63.07 & 5.87 & 23.47 \\
\hline 33 & 25.02 & 16.12 & 64.45 & 7.83 & 31.28 \\
\hline 36 & 25.04 & 16.41 & 65.54 & 7.98 & 31.86 \\
\hline 39 & 25.06 & 16.69 & 66.57 & 8.12 & 32.42 \\
\hline 42 & 25.09 & 16.94 & 67.53 & 8.26 & 32.93 \\
\hline 45 & 25.11 & 17.19 & 68.46 & 8.39 & 33.43 \\
\hline 48 & 25.13 & 17.44 & 69.40 & 8.52 & 33.93 \\
\hline 51 & 25.14 & 17.69 & 70.37 & 8.68 & 34.51 \\
\hline 54 & 25.16 & 18.00 & 71.54 & 8.88 & 35.30 \\
\hline 57 & 25.18 & 18.30 & 72.70 & 9.08 & 36.08 \\
\hline 60 & 25.20 & 18.60 & 73.82 & 9.28 & 36.83 \\
\hline $\begin{array}{c}\text { Discharge } \\
\left(\mathrm{ft}^{3} / \mathrm{s}\right)\end{array}$ & $\begin{array}{c}\text { Stream width } \\
\text { (ft) }\end{array}$ & $\begin{array}{l}\text { Total Stream } \\
\text { Width Greater } \\
\text { Than } 0.6 \mathrm{ft} \text { Depth }\end{array}$ & $\begin{array}{l}\text { Percent Stream } \\
\text { Width Greater } \\
\text { Than 0.6 ft Depth }\end{array}$ & $\begin{array}{c}\text { Contiguous Stream } \\
\text { Width Greater Than } \\
0.6 \mathrm{ft} \text { Depth }\end{array}$ & $\begin{array}{l}\text { Percent Contiguous } \\
\text { Stream Width Greater } \\
\text { Than } \mathbf{0 . 6} \mathrm{ft} \text { Depth }\end{array}$ \\
\hline 3 & 16.69 & 0.00 & 0.00 & 0.00 & 0.00 \\
\hline 4.8 & 17.59 & 0.60 & 3.44 & 0.60 & 3.44 \\
\hline 7 & 18.83 & 1.22 & 6.50 & 1.22 & 6.50 \\
\hline 9.6 & 19.98 & 1.80 & 9.01 & 1.80 & 9.01 \\
\hline 12 & 24.06 & 2.49 & 10.37 & 2.49 & 10.37 \\
\hline 15 & 24.44 & 2.95 & 12.06 & 2.95 & 12.06 \\
\hline 18 & 24.68 & 5.70 & 23.09 & 3.27 & 13.24 \\
\hline 21 & 24.77 & 5.95 & 24.01 & 3.44 & 13.88 \\
\hline 24 & 24.85 & 6.18 & 24.85 & 3.59 & 14.47 \\
\hline 27 & 24.92 & 6.39 & 25.63 & 3.74 & 15.01 \\
\hline 30 & 24.99 & 6.58 & 26.35 & 3.88 & 15.51 \\
\hline 33 & 25.02 & 7.12 & 28.47 & 3.96 & 15.84 \\
\hline 36 & 25.04 & 7.73 & 30.87 & 4.04 & 16.13 \\
\hline 39 & 25.06 & 8.31 & 33.14 & 4.11 & 16.41 \\
\hline 42 & 25.09 & 8.84 & 35.25 & 4.18 & 16.66 \\
\hline 45 & 25.11 & 9.37 & 37.30 & 4.25 & 16.91 \\
\hline 48 & 25.13 & 9.89 & 39.37 & 4.31 & 17.16 \\
\hline 51 & 25.14 & 12.46 & 49.57 & 4.95 & 19.68 \\
\hline 54 & 25.16 & 12.92 & 51.35 & 5.08 & 20.17 \\
\hline 57 & 25.18 & 13.38 & 53.13 & 5.20 & 20.66 \\
\hline 60 & 25.20 & 13.82 & 54.85 & 5.33 & 21.14 \\
\hline
\end{tabular}


Table 9A. Passage criteria assessment for transect 5 (wide high slope), site JC1, lower Fourth of July Creek, 2003Continued

\begin{tabular}{|c|c|c|c|c|c|}
\hline $\begin{array}{c}\text { Discharge } \\
\left(\mathrm{ft}^{3} / \mathrm{s}\right)\end{array}$ & $\begin{array}{c}\text { Stream width } \\
\text { (ft) }\end{array}$ & $\begin{array}{c}\text { Total Stream } \\
\text { Width Greater } \\
\text { Than } 0.8 \mathrm{ft} \text { Depth }\end{array}$ & $\begin{array}{l}\text { Percent Stream } \\
\text { Width Greater } \\
\text { Than } 0.8 \text { ft Depth }\end{array}$ & $\begin{array}{c}\text { Contiguous Stream } \\
\text { Width Greater Than } \\
0.8 \mathrm{ft} \text { Depth }\end{array}$ & $\begin{array}{l}\text { Percent Contiguous } \\
\text { Stream Width Greater } \\
\text { Than } \mathbf{0 . 8} \mathrm{ft} \text { Depth }\end{array}$ \\
\hline 3 & 16.69 & 0.00 & 0.00 & 0.00 & 0.00 \\
\hline 4.8 & 17.59 & 0.00 & 0.00 & 0.00 & 0.00 \\
\hline 7 & 18.83 & 0.00 & 0.00 & 0.00 & 0.00 \\
\hline 9.6 & 19.98 & 0.00 & 0.00 & 0.00 & 0.00 \\
\hline 12 & 24.06 & 0.00 & 0.00 & 0.00 & 0.00 \\
\hline 15 & 24.44 & 0.00 & 0.00 & 0.00 & 0.00 \\
\hline 18 & 24.68 & 0.72 & 2.90 & 0.72 & 2.90 \\
\hline 21 & 24.77 & 1.01 & 4.07 & 1.01 & 4.07 \\
\hline 24 & 24.85 & 1.28 & 5.14 & 1.28 & 5.14 \\
\hline 27 & 24.92 & 1.52 & 6.12 & 1.52 & 6.12 \\
\hline 30 & 24.99 & 1.76 & 7.04 & 1.76 & 7.04 \\
\hline 33 & 25.02 & 2.00 & 7.98 & 2.00 & 7.98 \\
\hline 36 & 25.04 & 2.24 & 8.92 & 2.24 & 8.92 \\
\hline 39 & 25.06 & 2.46 & 9.82 & 2.46 & 9.82 \\
\hline 42 & 25.09 & 2.67 & 10.65 & 2.67 & 10.65 \\
\hline 45 & 25.11 & 2.88 & 11.46 & 2.88 & 11.46 \\
\hline 48 & 25.13 & 3.08 & 12.27 & 3.08 & 12.27 \\
\hline 51 & 25.14 & 5.65 & 22.47 & 3.23 & 12.86 \\
\hline 54 & 25.16 & 5.78 & 22.97 & 3.32 & 13.21 \\
\hline 57 & 25.18 & 5.91 & 23.47 & 3.41 & 13.55 \\
\hline 60 & 25.20 & 6.03 & 23.95 & 3.50 & 13.88 \\
\hline
\end{tabular}




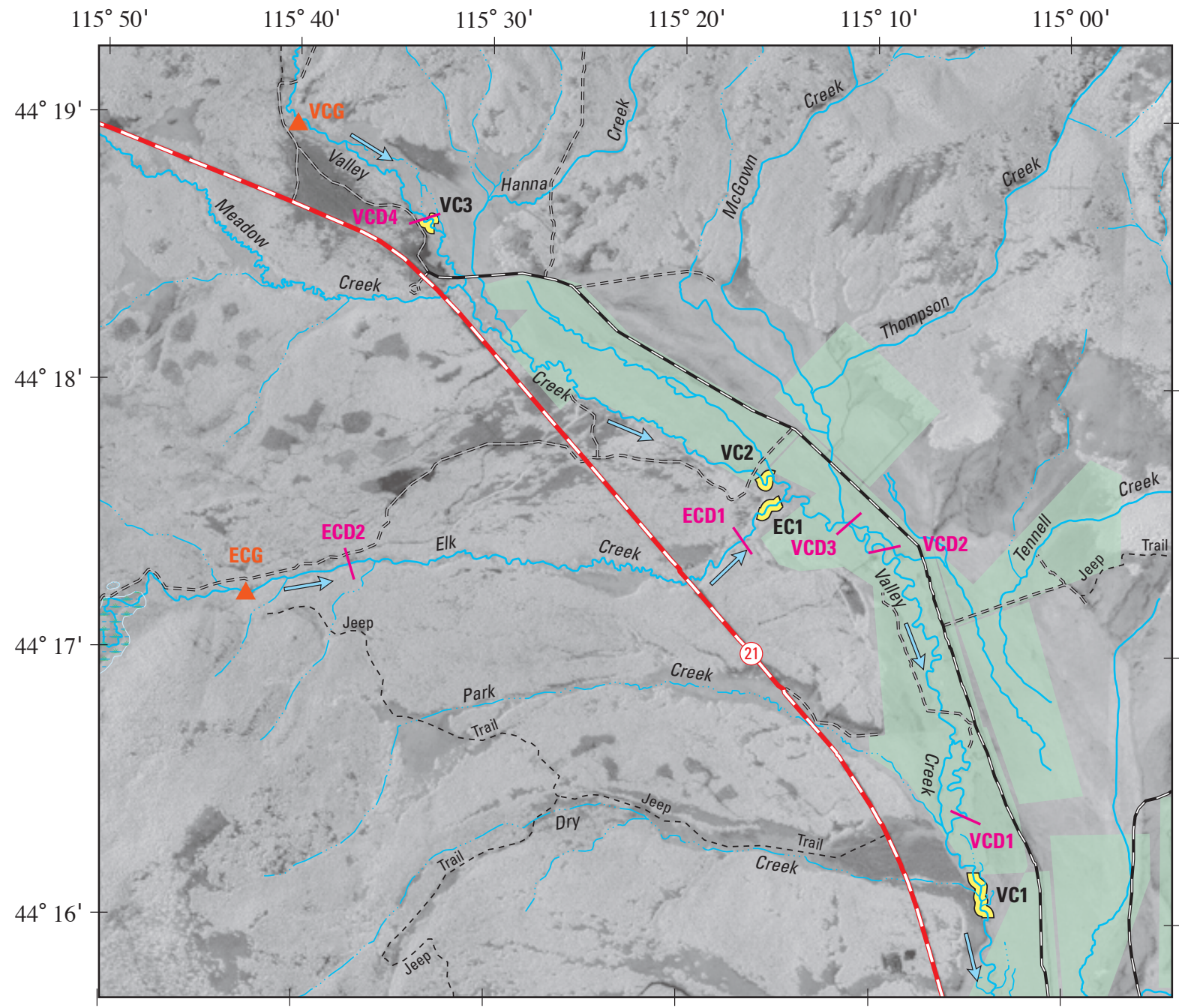

Base from U.S. Geological Survey digital data; 1998; 1:40,000,

Transverse Mercator projection; Factor at central meridian: 0.99960

Longitude of central meridian: $-114^{\circ} 00^{\prime}$; Latitude of origin: $42^{\circ} 00^{\prime}$

False easting (meters): 500,000; False northing (meters): 100,000

Hydrography from U.S. Geological Survey; 1999; 1:24,000
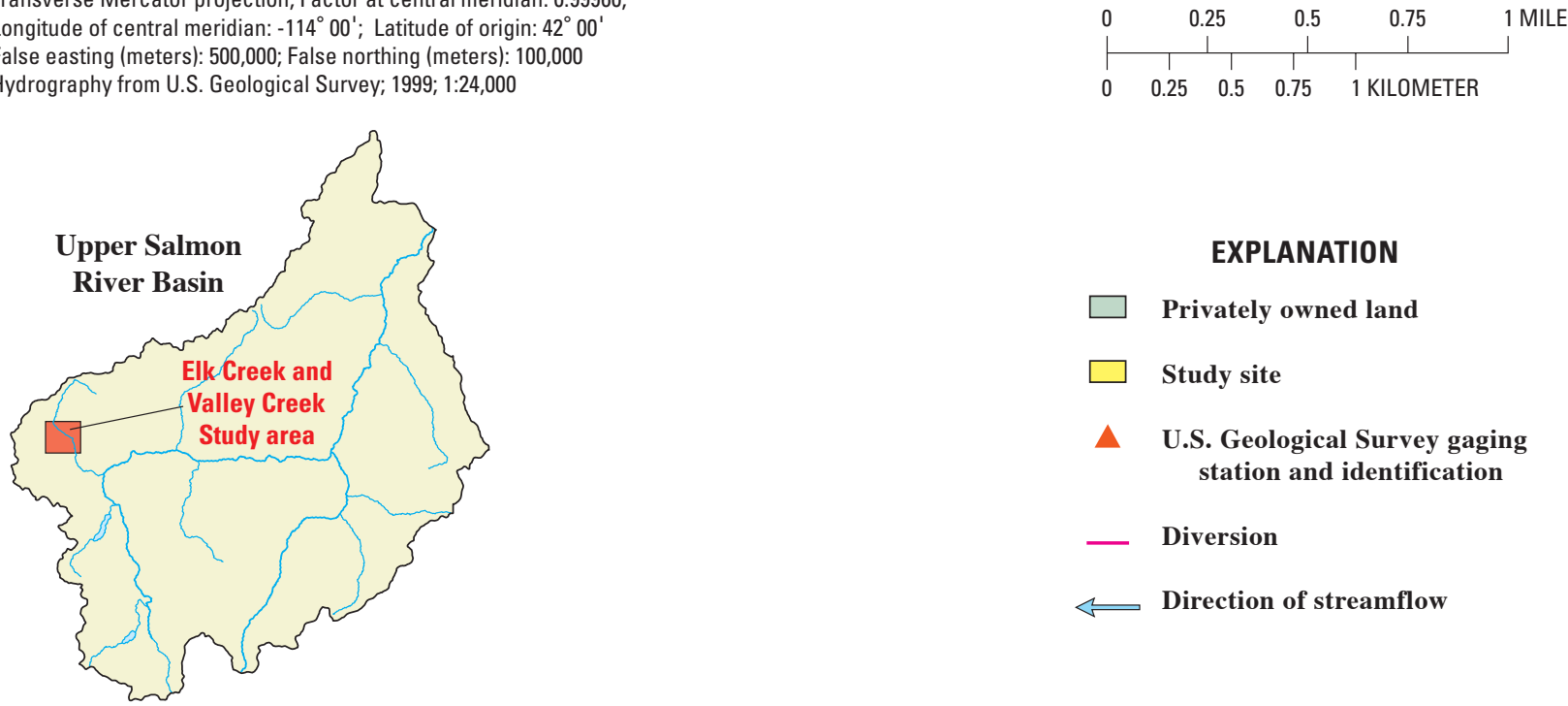

EXPLANATION

Privately owned land

Study site

$\Delta \quad$ U.S. Geological Survey gaging station and identification

— Diversion

$\Longleftarrow$ Direction of streamflow

Figure 12. Elk Creek and Valley Creek study sites, diversions, and gaging station locations, upper Salmon River Basin, Idaho, 2003 (Basin and site characteristics shown in table 1) 


\section{Elk Creek (click here for abbreviations used in figures $39 \mathrm{~A}-47 \mathrm{~A}$ and tables 10A-11A)}

Elk Creek is located in the northwest portion of the upper Salmon River Basin. It is a tributary to Valley Creek and its headwaters originate in the upper elevations of the Sawtooth Range (figure 1). The Elk Creek Basin covers $20.4 \mathrm{mi}^{2}$, of which about 67 percent is forest. The basin has a mean elevation of about 7,470 ft above sea level and receives an average of $26 \mathrm{in}$. of precipitation per year.

\section{Hydrology During 2003}

A short-term streamflow gaging station (13294640) was installed and operated on Elk Creek during the period June 1 through October 5, 2003. The gage was located in a heavily forested area, upstream from all active diversions, about $1 \mathrm{mi}$ downstream from Elk Meadow, and about 3 mi upstream from the confluence with Valley Creek (figure 12; ECG). Stage data were collected at 15-minute intervals and five instantaneous discharge measurements were completed. Stage-discharge relations from the instantaneous measurements were used to determine discharges at each 15-minute interval, resulting in a continuous record of streamflow. A plot of the continuous daily mean discharge in Elk Creek upstream from the diversions during WY03 is presented in figure 13, along with markers indicating the times when field data were collected at the study site, which was located downstream from the diversions.

Additional analyses were completed to relate streamflows during WY03 to long-term means. The same techniques used to estimate long-term streamflows for Pole Creek also were used for Elk Creek. The July, August, and September daily mean discharge hydrograph for Elk Creek upstream from diversions (13294640) for WY03 and the estimated long-term daily mean hydrograph are presented in figure 14 . Also presented in figure 14 are estimated monthly streamflow exceedance statistics for the gaging station location based on regional regression equations developed by Hortness and Berenbrock (2001). Again, the median estimate gives an indication of long-term average streamflow conditions, and the other estimates provide an indication of the probable variation in streamflows at this location.

The 80-, 50-, and 20-percent monthly exceedance discharge values were estimated on the basis of WY03 daily mean discharge values and estimated long-term daily mean discharge values at the Elk Creek gaging station (13294640)

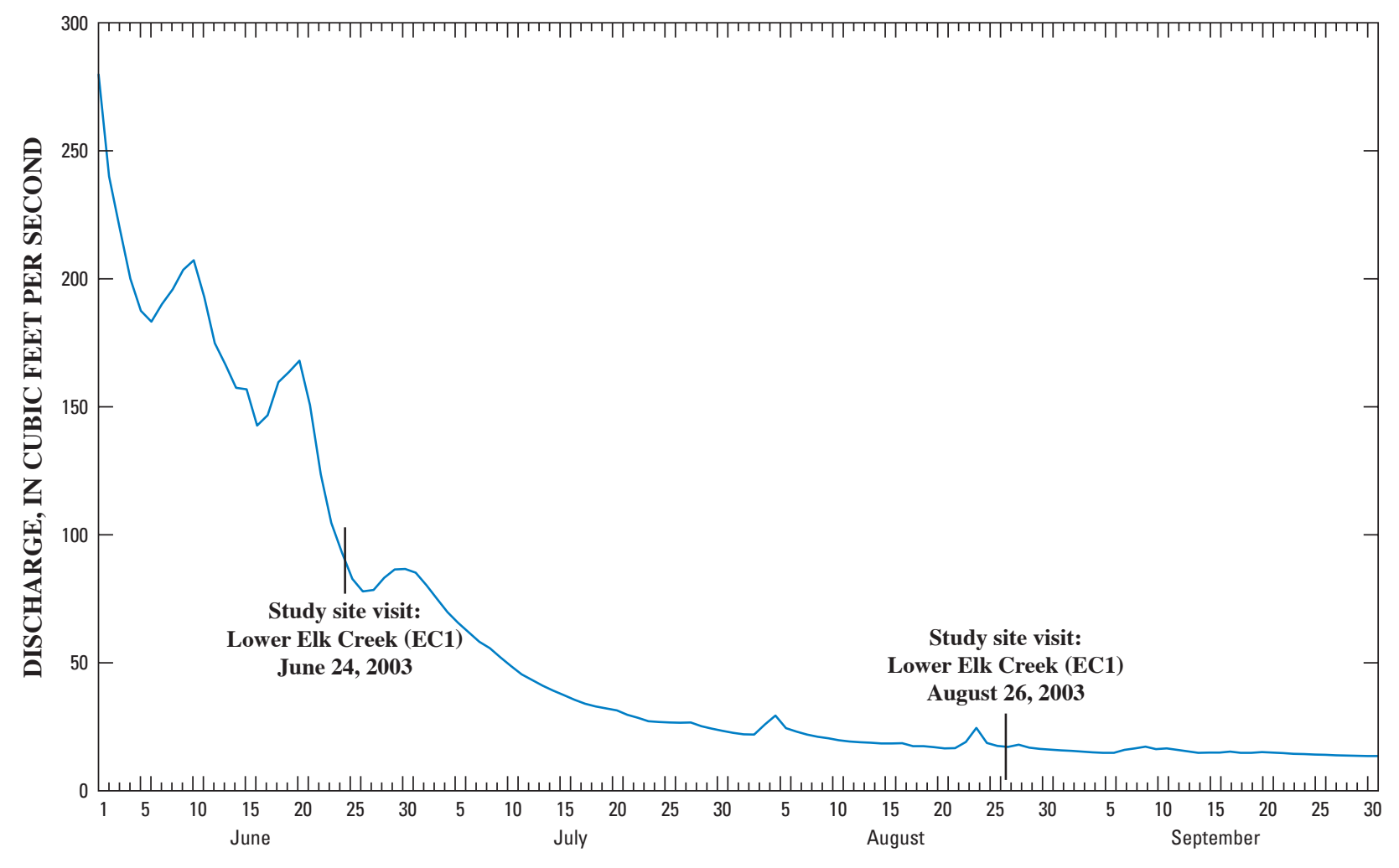

MONTH

Figure 13. Daily mean discharge at lower Elk Creek upstream from diversions near Stanley (13294640), upper Salmon River Basin, Idaho, June 1 through September 30, 2003 


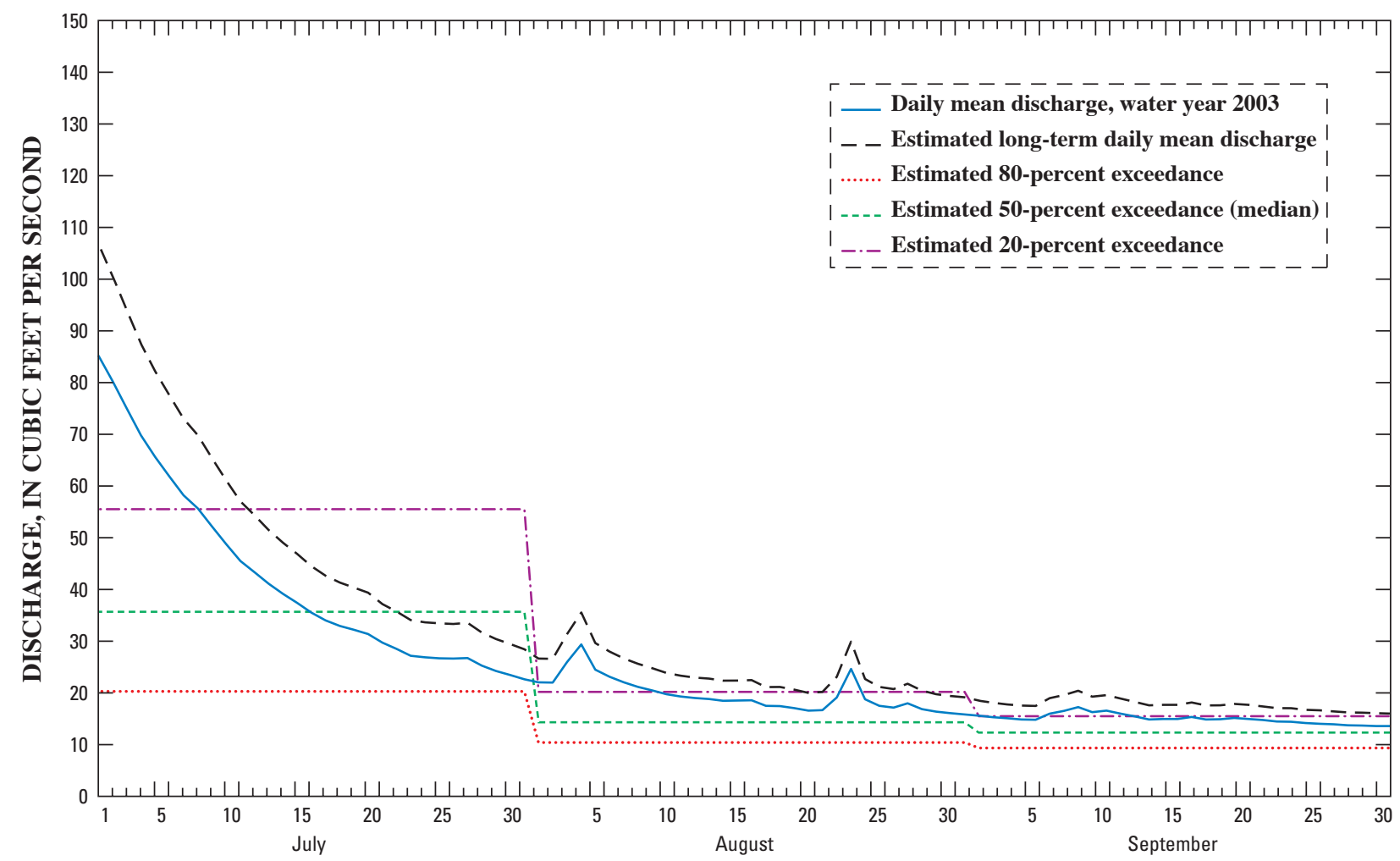

MONTH

Figure 14. Daily mean discharge for water year 2003, estimated long-term daily mean discharge, and estimated 80-, 50-, and 20-percent exceedance statistics for Elk Creek upstream from diversions near Stanley (13294640), upper Salmon River Basin, Idaho, July 1 through September 30

Table 8. Calculated and estimated 80-, 50-, and 20-percent monthly exceedance discharge values for Elk Creek upstream from diversions near Stanley (13294640), upper Salmon River Basin, Idaho, 2003

[Q, discharge; values presented in cubic feet per second]

\begin{tabular}{|c|c|c|c|c|c|c|c|c|c|c|}
\hline & & \multicolumn{3}{|c|}{ July } & \multicolumn{3}{|c|}{ August } & \multicolumn{3}{|c|}{ September } \\
\hline & & 0.80 & 0.50 & 0.20 & 0.80 & 0.50 & 0.20 & 0.80 & 0.50 & 0.20 \\
\hline \multirow{3}{*}{ 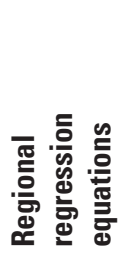 } & Water year 2003 & 26.8 & 35.5 & 58.2 & 17.1 & 18.7 & 22.0 & 14.1 & 14.9 & 15.7 \\
\hline & Upper confidence limit & 31.4 & 51.6 & 77.4 & 17.8 & 22.7 & 30.3 & 16.3 & 17.9 & 21.9 \\
\hline & Estimate & 20.3 & 35.7 & 55.5 & 10.4 & 14.3 & 20.2 & 9.34 & 12.3 & 15.5 \\
\hline
\end{tabular}

\footnotetext{
${ }^{1}$ Estimate based on comparisons between water year 2003 and long-term monthly mean discharges at Valley Creek at Stanley (13295000).
} 
(table 8). Exceedance estimates, along with the confidence limits, also were derived from the regional regression equations (Hortness and Berenbrock, 2001) for this location (table 8). Comparison between the estimated long-term daily mean discharge values and values calculated on the basis of the regression equations can provide some insight as to the applicability of the regression equations for Elk Creek. As was apparent in figure 14, the regression estimates tend to be lower than the estimated long-term values, indicating that the equations, to some degree, could underestimate streamflow conditions in Elk Creek.

In addition to the continuous-record data, instantaneous discharge was measured at the mouth of Elk Creek (13294650) (figure 12). Although seepage analyses were not within the scope of this project, instantaneous discharge measurements provide some indication of the amount of streamflow lost to ground water and the amount being diverted at specific times during the study period. A summary of all discharge measured in Elk Creek during the study period is presented in table 9.

\section{Habitat Modeling and Passage Results}

Lower Elk Creek (EC1) discharges required for maximum WUA ranged from 34 to $59 \mathrm{ft}^{3} / \mathrm{s}, 18$ to $62 \mathrm{ft}^{3} / \mathrm{s}$, and 18 to $62 \mathrm{ft}^{3} / \mathrm{s}$ for bull trout, chinook salmon, and steelhead trout life stages, respectively (table 10). Pool habitat was absent in the stream segment surveyed, indicating this stream may have limited juvenile rearing habitat. Discharges required for passage over shallow riffle habitat ranged from 34 to $12 \mathrm{ft}^{3} / \mathrm{s}$ for the depth criterion of $0.6 \mathrm{ft}$ over 25 percent of the total channel width and over 10 percent of the contiguous channel width, respectively. The transect where passage was evaluated
Table 9. Miscellaneous discharge measurements collected on Elk Creek, upper Salmon River Basin, Idaho, 2003

[Basin and site characteristics shown in table 1; locations shown in figure 12; ECG, Elk Creek at U.S. Geological Survey gage; EC1, Lower Elk Creek; values presented in cubic feet per second; - , no data available]

\begin{tabular}{c|c|c}
\hline Date & ECG $^{1}$ & EC1 \\
\hline $6 / 24 / 03$ & $\underline{93.0}$ & 82.7 \\
\hline $7 / 31 / 03$ & $\underline{23.0}$ & - \\
\hline $8 / 26 / 03$ & $\underline{17.0}$ & 9.80 \\
\hline $8 / 28 / 03$ & 17.8 & 10.3 \\
\hline $10 / 6 / 03$ & 13.6 & 12.0 \\
\hline
\end{tabular}

${ }^{1}$ Daily mean discharge values are underlined.

was exceptionally wide and shallow at the mouth of Elk Creek (see transect 1 photo at http://id.water.usgs.gov/projects/salmon streamflow). This was the result of the buildup of a large alluvial deposit from a previous high-discharge event. Scott and others (1981), using a passage criterion similar to that used in this study, estimated that a lower discharge of $4 \mathrm{ft}^{3} / \mathrm{s}$ would provide passage for chinook salmon. For more information summarizing the results of this study, see the appendices, figures 39A-47A and tables 10A-11A.

Maximum WUA estimates determined by Utah State University in 1999 (M. Combs, Utah State University, written commun., 2003) at this same study site were compared with maximum WUA estimates in this study. The University's WUA estimates ranged from 13 to $36 \mathrm{ft}^{3} / \mathrm{s}, 13$ to $64 \mathrm{ft}^{3} / \mathrm{s}$, and

Table 10. Habitat and discharge measurements for lower Elk Creek (EC1), upper Salmon River Basin, Idaho, 2003

[WUA, weighted usable area; $\mathrm{ft}^{3} / \mathrm{s}$, cubic feet per second. WUA maximum discharge estimates were based on Physical Habitat Simulation Model output; Q.xx, daily discharge exceeded xx percent of the time during the specified month, in $\mathrm{ft}^{3} / \mathrm{s}$; Qa, mean annual discharge, in $\mathrm{ft}^{3} / \mathrm{s}$; ND, not determined]

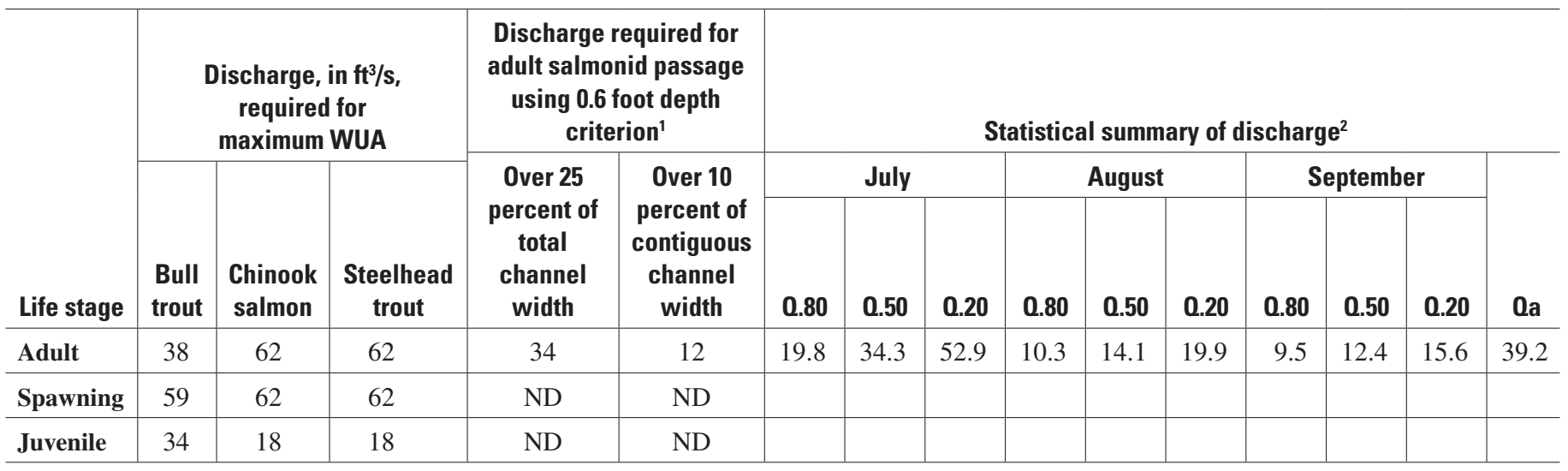

${ }^{1}$ Passage criterion from Thompson (1972) and Scott and others (1981); depth over both width measurements must be met to ensure passage.

${ }^{2}$ Discharge statistics derived from regional regression equations using basin and climatic characteristics (Hortness and Berenbrock, 2001). 
18 to $64 \mathrm{ft}^{3} / \mathrm{s}$ for bull trout, chinook salmon, and steelhead trout, respectively, for the same three life stages. Their maximum WUA estimates for bull trout are much lower than estimates in this study, whereas their WUA estimates are similar to those in this study for chinook salmon and steelhead trout. Reason(s) for the large differences in maximum WUA estimates for bull trout could not be evaluated because the University's study is unpublished.

Median discharge (Q.50) estimates, based on regression equations, for the months of July, August, and September are $34.3,14.1$, and $12.4 \mathrm{ft}^{3} / \mathrm{s}$, respectively. The mean annual discharge estimate is $39.2 \mathrm{ft}^{3} / \mathrm{s}$ (table 10). As indicated earlier, on the basis of WY03, the regression equations might, to some degree, underestimate streamflow statistics for lower Elk Creek. Adjustments to these estimates would be possible on the basis of comparison information provided in figure 14 and table 8 . However, any adjustments would be somewhat crude, because they would be based on only 1 partial year of streamflow data.

\section{Stream Temperature Results}

Two data loggers were deployed in Elk Creek to record water temperature in 2003 (figure 12). One data logger was deployed near the USGS short-term gaging station (ECG) upstream from all diversions; the other was deployed at the PHABSIM study site EC1 downstream from all diversions, near the mouth of Elk Creek. Both data loggers were deployed in late June and retrieved in late September. After the data were downloaded, June 19 through September 29 (102 days) was selected as the period of record for calculating stream temperature metrics.

Analysis of the stream temperature metrics for Elk Creek indicated a slight cooling trend downstream from ECG to EC1 (figure 15). This possibly is due to the dense riparian shading along Elk Creek downstream from ECG, which may have a cooling effect on water previously warmed as it travels through Elk Meadows, a large meadow complex upstream from ECG. Although there are two diversions (ECD2 and ECD1) on Elk Creek downstream from ECG, they did not appear to increase stream temperature in 2003. Perhaps this is because the upper diversion diverts such a small portion of the total streamflow that its effect is negligible and the proximity of the lower diversion to study site EC1 is so close that its effect on stream temperature may not be evident in the short distance between it and study site EC1. Regardless of the reason, the effect of these diversions appears to be minimized by the natural cooling taking place in the lower end of Elk Creek.

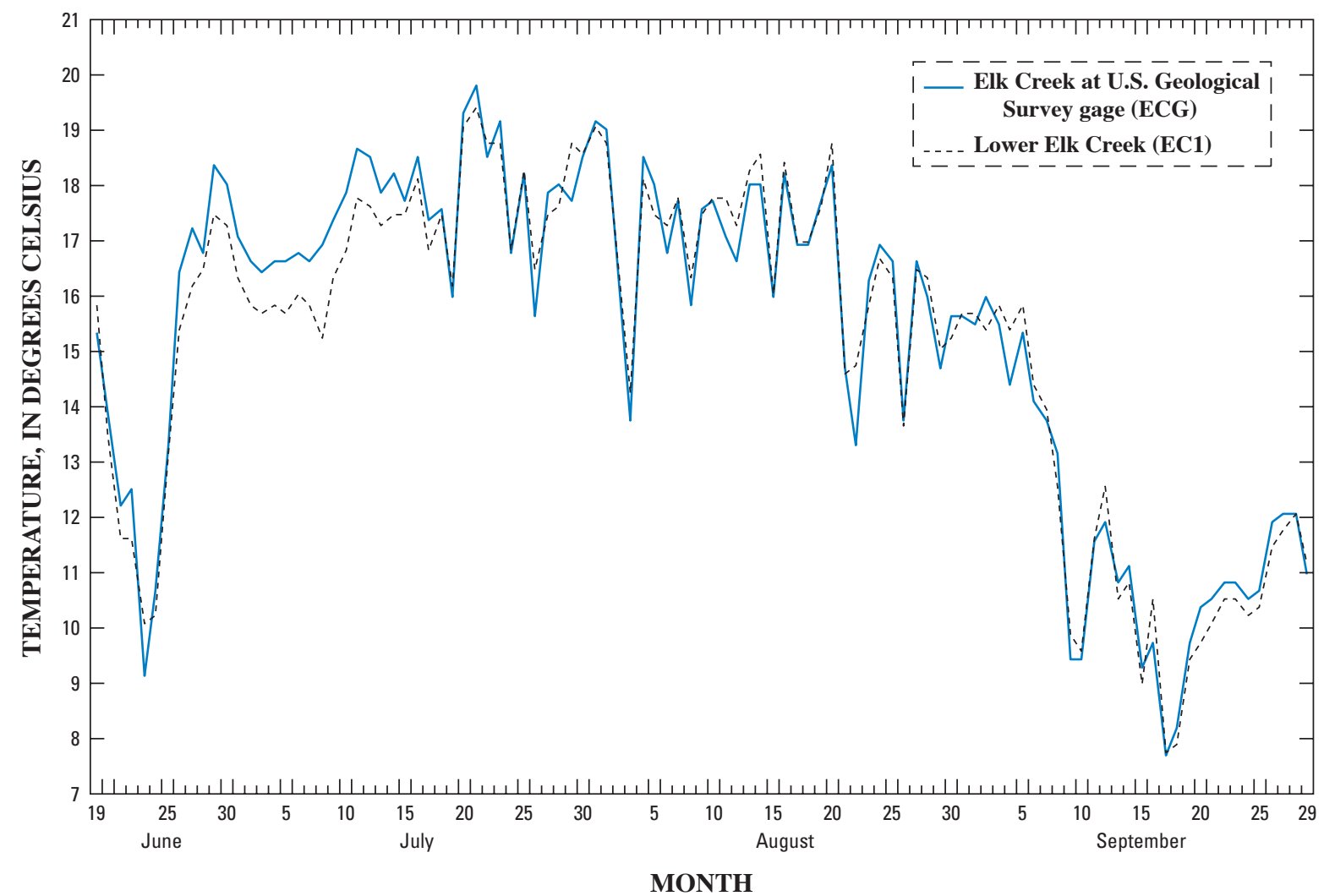

Figure 15. Maximum daily water temperature for period June 19 through September 29, 2003, at Elk Creek, upper Salmon River Basin, Idaho 
Because of this cooling trend, the stream temperature model, SSTEMP, was not applied to Elk Creek.

Results of the individual metric calculations showed that the MDMT was $19.8^{\circ} \mathrm{C}$ at ECG and $19.4^{\circ} \mathrm{C}$ at EC1, occurring on July 21 at both sites, and was below the $21.0^{\circ} \mathrm{C}$ threshold that, according to Poole and others (2001), can create a thermal barrier that would block adult chinook salmon from migrating to their spawning grounds. The MDMT exceeded $18.0^{\circ} \mathrm{C}$ in July and August at both Elk Creek sites, indicating there may be decreased bull trout habitat and blocked passage in Elk Creek as a result of high temperatures (J. Dunham, U.S. Forest Service, written commun., 2004). No stream temperatures at ECG and EC1 exceeded the IDEQ $19.0^{\circ} \mathrm{C}$ MDAT and $22.0^{\circ} \mathrm{C}$ MDMT criteria for the protection of coldwater biota during the period of record. A summary of the individual temperature metrics for all study sites can be accessed at http://id.water.usgs.gov/projects/salmon_streamflow

\section{Elk Creek Appendix Abbreviations}

Contiguous, continuous width with equal or greater water depth

Discharge, in $\mathrm{ft}^{3} / \mathrm{s}$

$\mathrm{ft}$, feet

$\mathrm{ft}^{2}$, square feet

$\mathrm{ft}^{3} / \mathrm{s}$, cubic feet per second

$\mathrm{EC} 1$, site number (see table 1)

$\mathrm{RM} 1$, local reference mark

Stream width, in $\mathrm{ft}$

$\mathrm{T} 1$, transect number

Total Area, study site area, in $\mathrm{ft}^{2}$

WUA, weighted usable area, in $\mathrm{ft}^{2}$ per $1,000 \mathrm{ft}$ of stream 


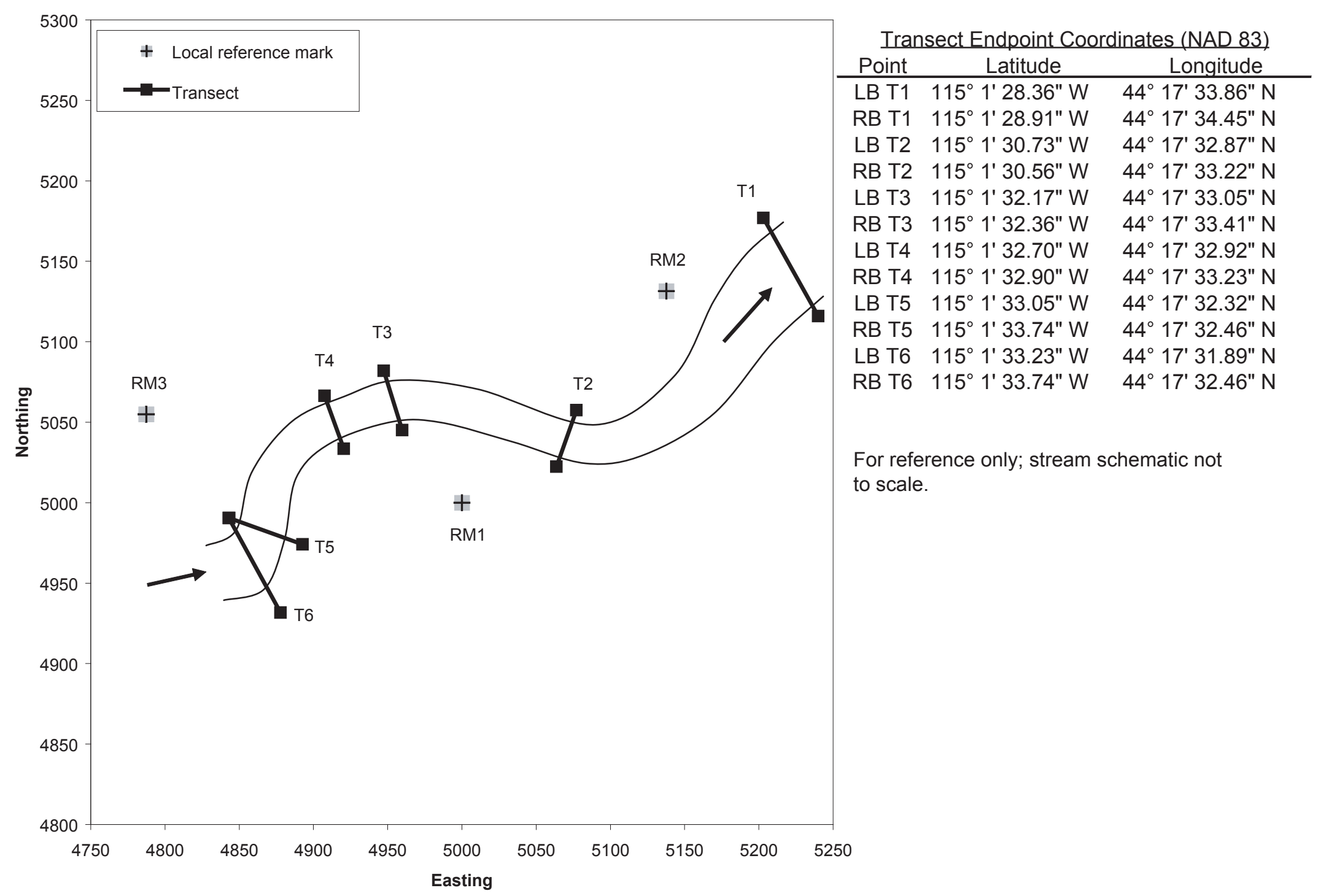


Figure 40A

Lower Elk Creek - EC1

Bull Trout WUA

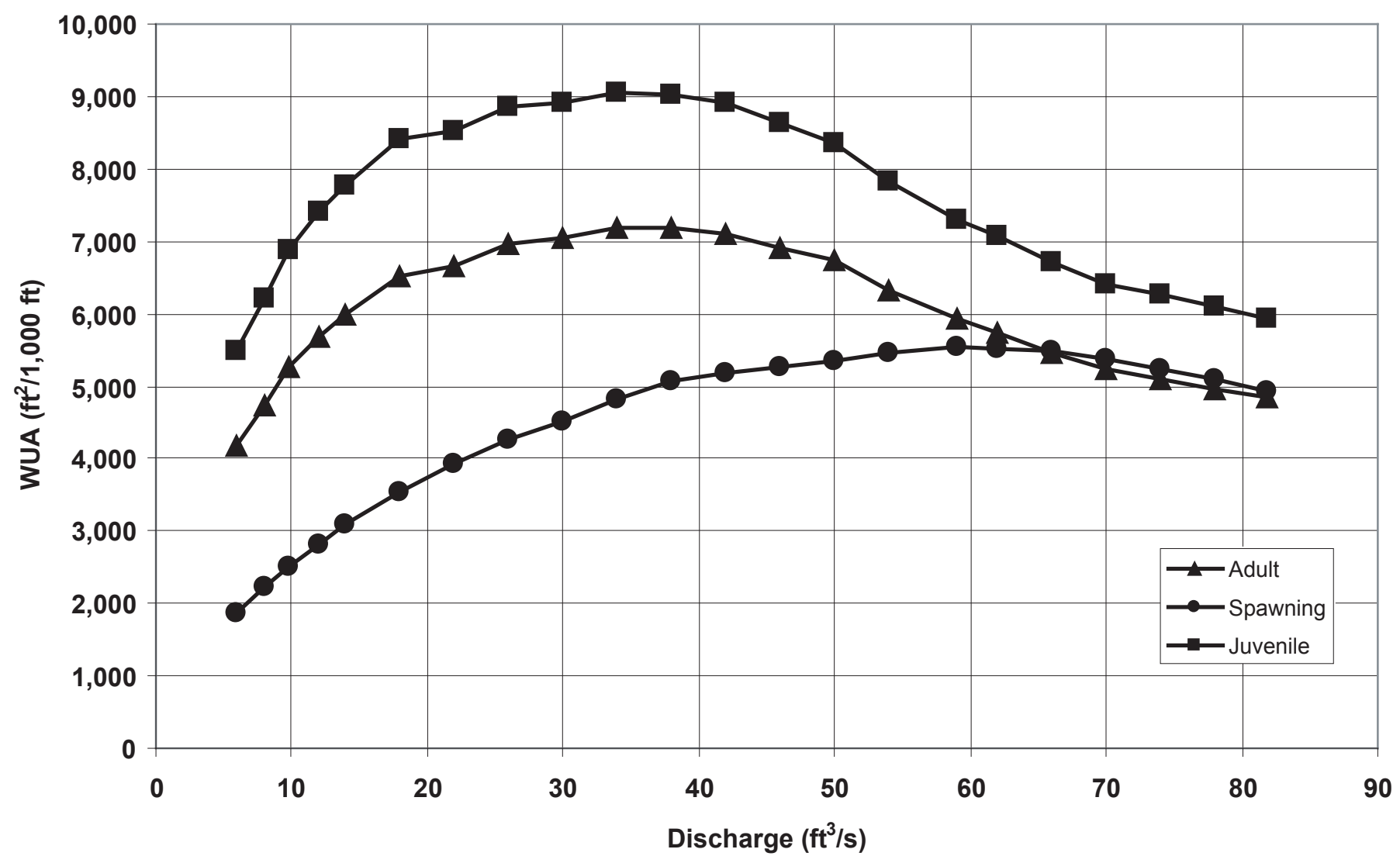


Figure 41A

Lower Elk Creek - EC1

Bull Trout WUA Normalized

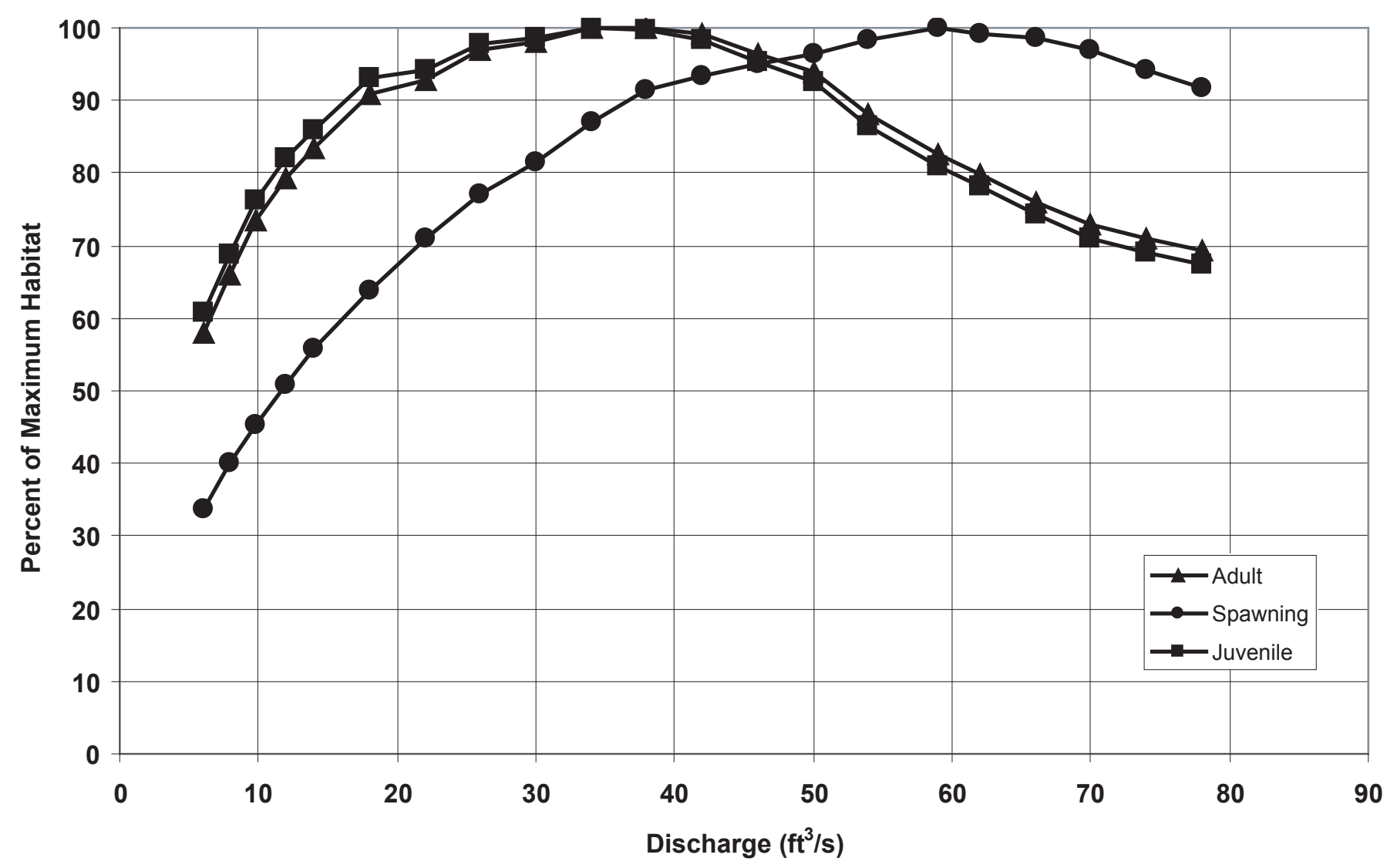


Figure 42A

Lower Elk Creek - EC1

Chinook Salmon WUA

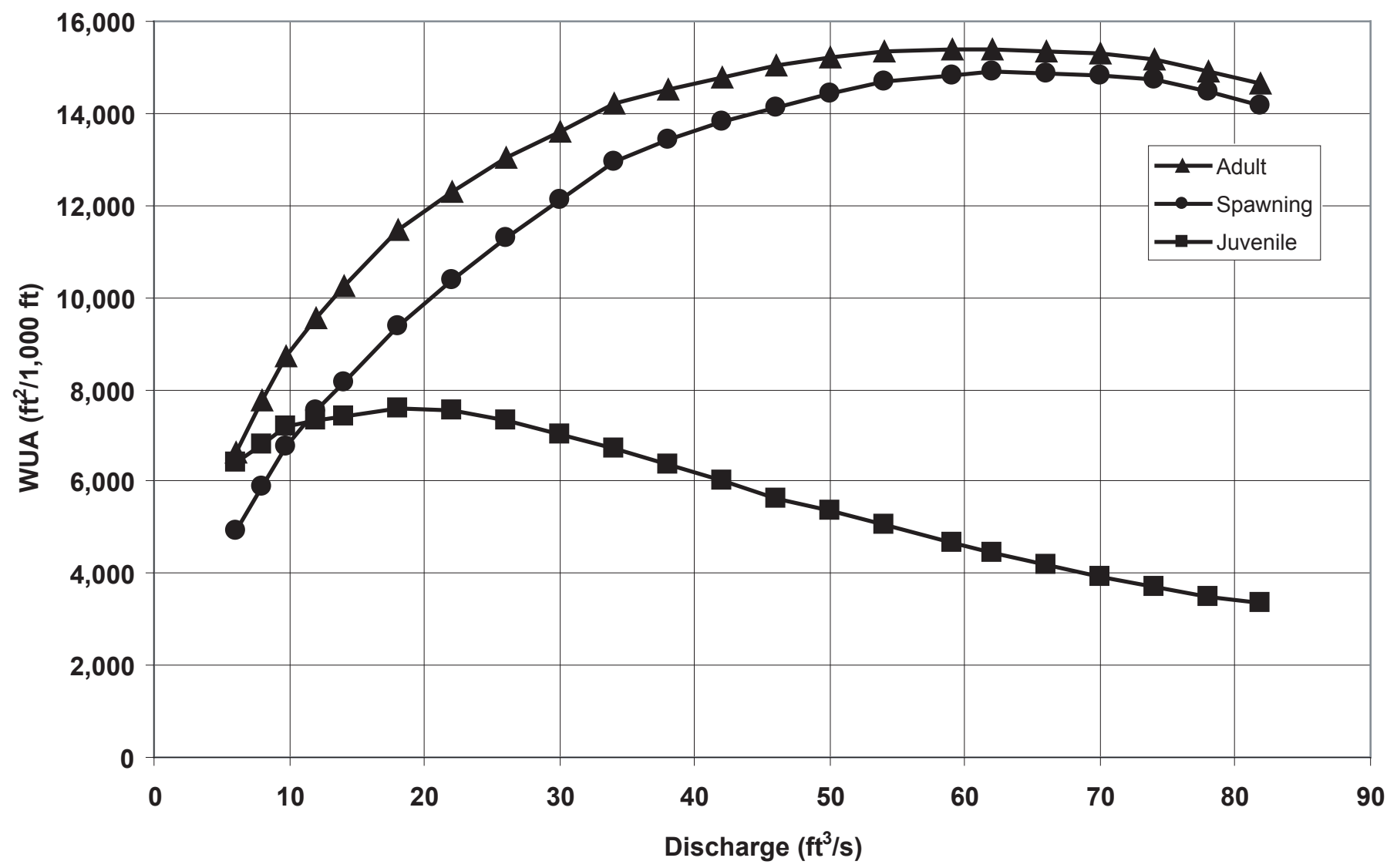


Figure 43A

Lower Elk Creek - EC1

Chinook Salmon WUA Normalized

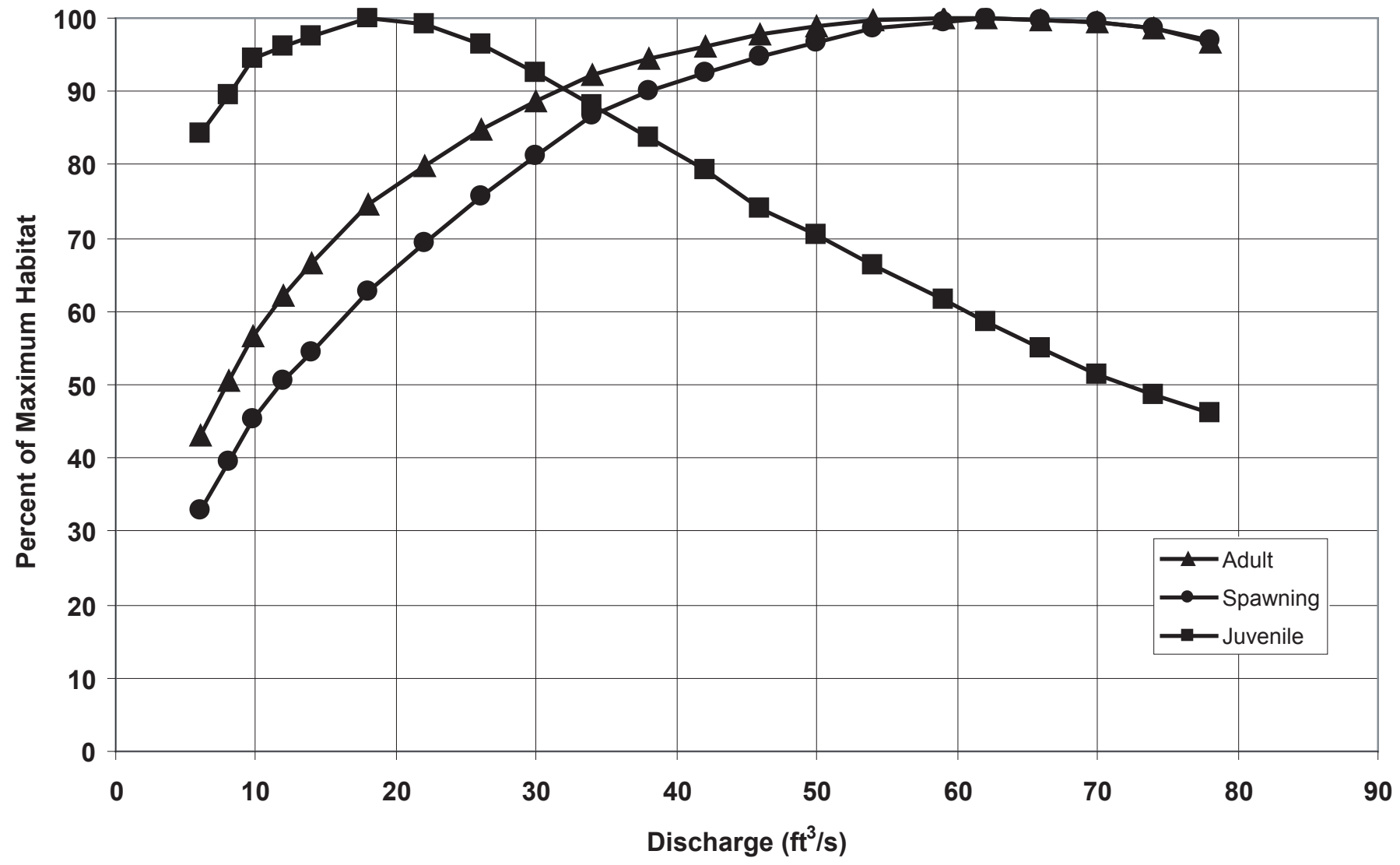


Figure 44A

Lower Elk Creek - EC1

Steelhead WUA

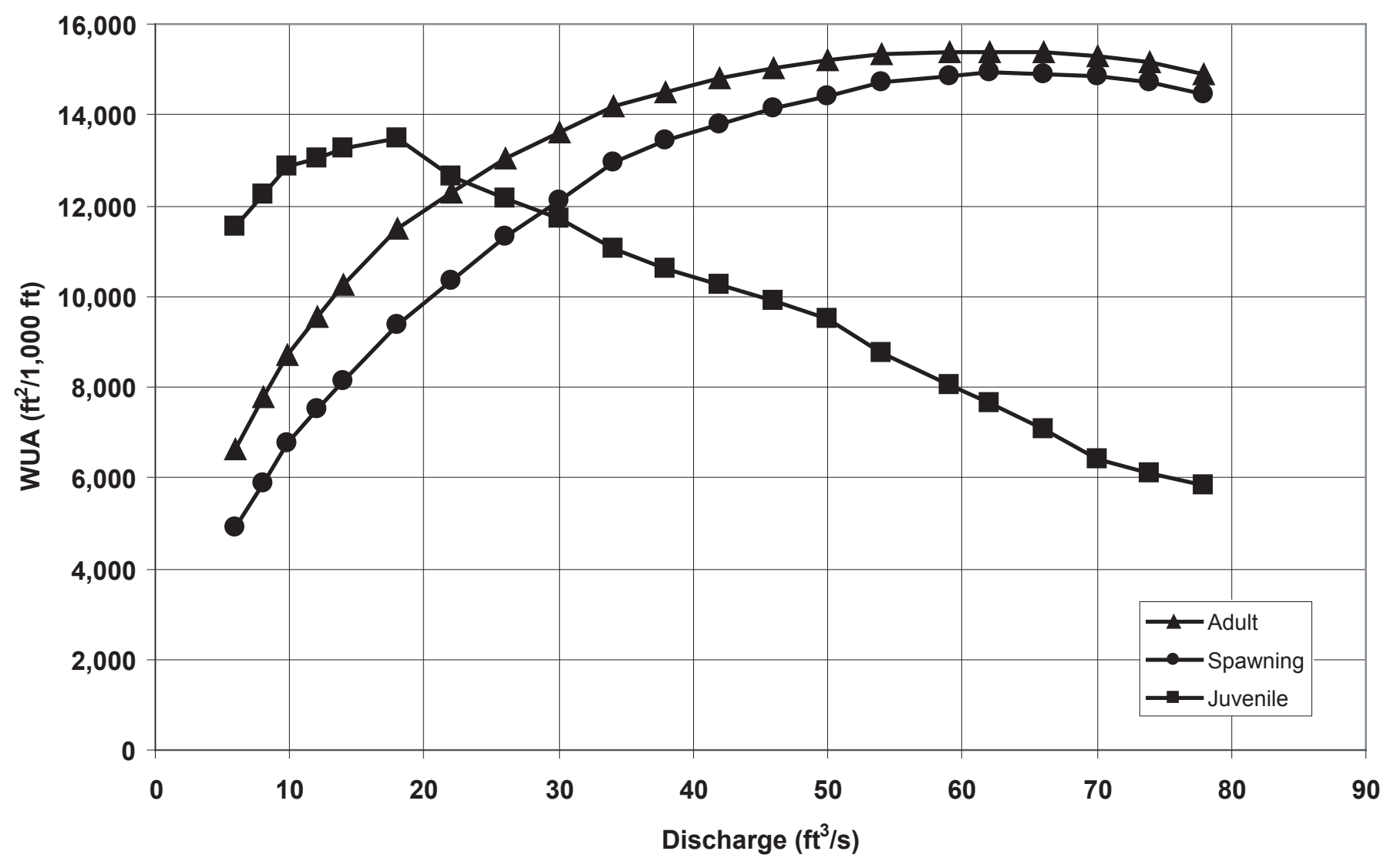


Figure 45A

Lower Elk Creek - EC1

Steelhead WUA Normalized

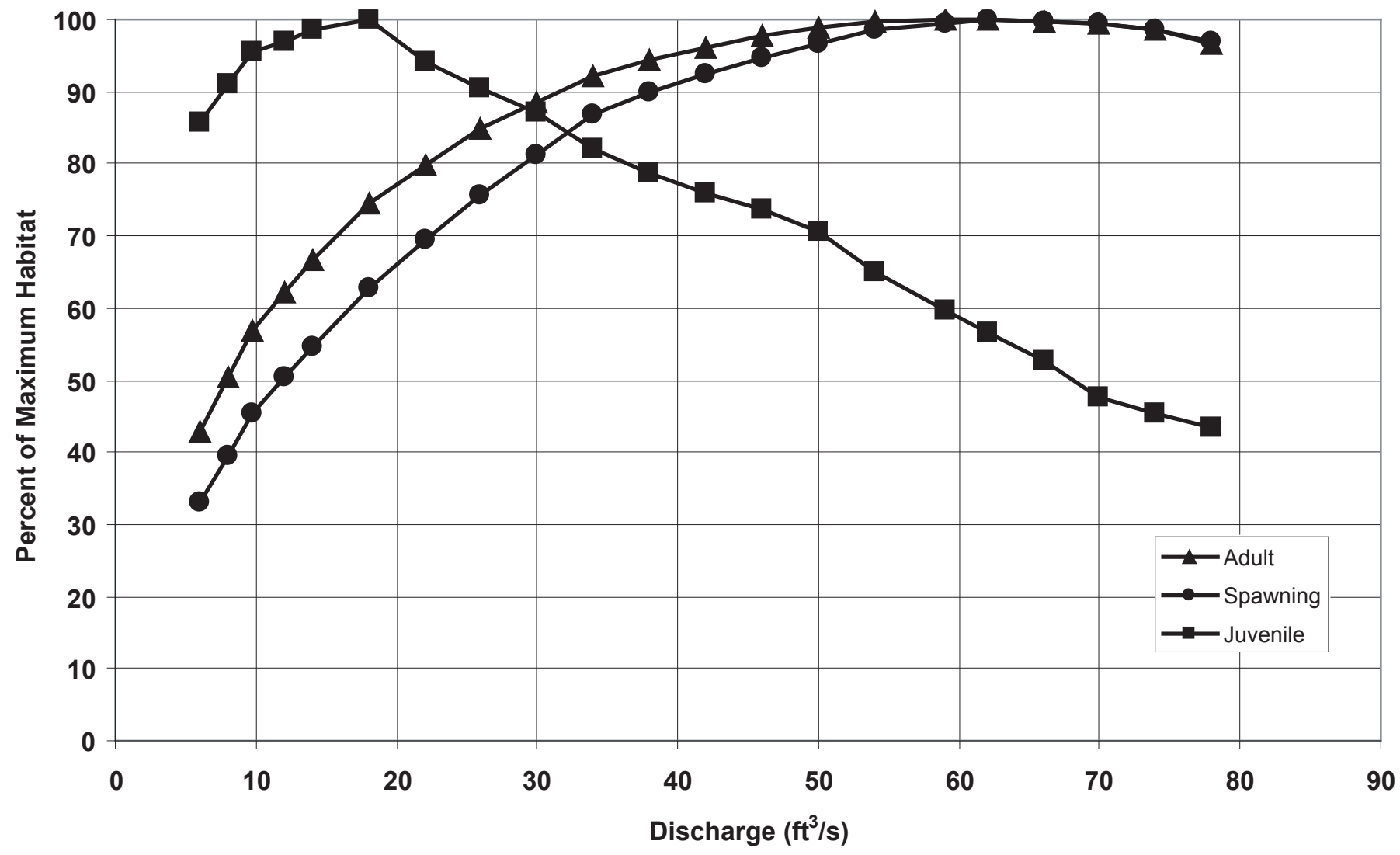


Table 10A. Weighted usable area for bull trout, chinook salmon, steelhead trout life stages, and cover for juvenile life stages, site EC1, lower Elk Creek, 2003

\section{BULL TROUT}

\begin{tabular}{|c|c|c|c|c|c|c|c|c|}
\hline \multirow{2}{*}{$\begin{array}{c}\text { Discharge } \\
\qquad\left(\mathrm{ft}^{3} / \mathrm{s}\right)\end{array}$} & \multirow{2}{*}{$\begin{array}{c}\text { Total Area } \\
\left(\mathrm{ftt}^{2}\right)\end{array}$} & \multicolumn{4}{|c|}{ Summary of Weighted Usable Area $\left(\mathrm{ft}^{2} / 1000 \mathrm{ft}\right)$} & \multicolumn{3}{|c|}{ Percent of Optimum } \\
\hline & & Adult & Spawning & Juvenile & Cover & Adult & Spawning & Juvenile \\
\hline 6 & 20526.5 & 4170.1 & 1877.4 & 5490.2 & 287.9 & 58.07 & 33.82 & 60.69 \\
\hline 8 & 21757.1 & 4744.5 & 2218.9 & 6219.1 & 339.8 & 66.07 & 39.98 & 68.75 \\
\hline 9.77 & 23472.3 & 5267.5 & 2510.0 & 6889.8 & 391.0 & 73.35 & 45.22 & 76.17 \\
\hline 12 & 23874.7 & 5692.9 & 2826.3 & 7414.5 & 443.9 & 79.28 & 50.92 & 81.97 \\
\hline 14 & 24335.5 & 5992.7 & 3094.3 & 7775.6 & 500.4 & 83.45 & 55.75 & 85.96 \\
\hline 18 & 25934.0 & 6530.8 & 3537.3 & 8416.5 & 666.8 & 90.94 & 63.73 & 93.04 \\
\hline 22 & 26323.6 & 6667.5 & 3939.8 & 8524.1 & 798.2 & 92.85 & 70.98 & 94.23 \\
\hline 26 & 26640.1 & 6956.9 & 4273.7 & 8847.2 & 875.8 & 96.88 & 77.00 & 97.81 \\
\hline 30 & 26928.4 & 7044.3 & 4523.9 & 8912.7 & 954.8 & 98.09 & 81.51 & 98.53 \\
\hline 34 & 27300.1 & 7174.5 & 4824.2 & 9045.7 & 1074.1 & 99.91 & 86.92 & 100.00 \\
\hline 38 & 27441.8 & 7181.1 & 5071.9 & 9019.9 & 1161.3 & 100.00 & 91.38 & 99.71 \\
\hline 42 & 27735.5 & 7111.9 & 5184.1 & 8902.0 & 1285.9 & 99.04 & 93.40 & 98.41 \\
\hline 46 & 27830.9 & 6919.4 & 5277.9 & 8632.0 & 1318.0 & 96.36 & 95.09 & 95.43 \\
\hline 50 & 28194.7 & 6736.5 & 5356.2 & 8363.7 & 1312.0 & 93.81 & 96.50 & 92.46 \\
\hline 54 & 28324.4 & 6328.2 & 5465.6 & 7825.5 & 1326.6 & 88.12 & 98.47 & 86.51 \\
\hline 59 & 28457.2 & 5930.3 & 5550.4 & 7311.7 & 1457.7 & 82.58 & 100.00 & 80.83 \\
\hline 62 & 28532.7 & 5739.9 & 5509.2 & 7082.0 & 1507.4 & 79.93 & 99.26 & 78.29 \\
\hline 66 & 28627.9 & 5455.3 & 5478.4 & 6721.2 & 1558.3 & 75.97 & 98.70 & 74.30 \\
\hline 70 & 28710.2 & 5228.0 & 5376.4 & 6419.2 & 1599.0 & 72.80 & 96.87 & 70.96 \\
\hline 74 & 28789.3 & 5100.9 & 5233.6 & 6256.1 & 1630.2 & 71.03 & 94.29 & 69.16 \\
\hline 78 & 28864.6 & 4970.8 & 5086.2 & 6099.4 & 1700.1 & 69.22 & 91.64 & 67.43 \\
\hline 81.8 & 28936.8 & 4835.6 & 4939.4 & 5942.3 & 1740.9 & 67.34 & 88.99 & 65.69 \\
\hline
\end{tabular}


104 Instream Flow Characterization of Upper Salmon River Basin Streams, Central Idaho, 2003

Table 10A. Weighted usable area for bull trout, chinook salmon, steelhead trout life stages, and cover for juvenile life stages, site EC1, lower Elk Creek, 2003 - Continued

CHINOOK SALMON

\begin{tabular}{|c|c|c|c|c|c|c|c|c|}
\hline \multirow{2}{*}{$\begin{array}{c}\text { Discharge } \\
\left(\mathrm{ft}^{3} / \mathrm{s}\right)\end{array}$} & \multirow{2}{*}{$\begin{array}{c}\text { Total Area } \\
\quad\left(\mathrm{ft}^{2}\right)\end{array}$} & \multicolumn{4}{|c|}{ Summary of Weighted Usable Area $\left(\mathrm{ft}^{2} / 1000 \mathrm{ft}\right)$} & \multicolumn{3}{|c|}{ Percent of Optimum } \\
\hline & & Adult & Spawning & Juvenile & Cover & Adult & Spawning & Juvenile \\
\hline 6 & 20526.5 & 6614.8 & 4918.0 & 6398.8 & 360.8 & 42.99 & 32.96 & 84.15 \\
\hline 8 & 21757.1 & 7769.2 & 5878.7 & 6810.1 & 427.2 & 50.50 & 39.40 & 89.56 \\
\hline 9.77 & 23472.3 & 8727.6 & 6763.6 & 7182.8 & 478.1 & 56.73 & 45.33 & 94.47 \\
\hline 12 & 23874.7 & 9547.7 & 7524.5 & 7307.5 & 526.9 & 62.06 & 50.43 & 96.11 \\
\hline 14 & 24335.5 & 10256.5 & 8138.8 & 7405.4 & 580.8 & 66.66 & 54.55 & 97.39 \\
\hline 18 & 25934.0 & 11481.0 & 9368.0 & 7603.6 & 733.6 & 74.62 & 62.79 & 100.00 \\
\hline 22 & 26323.6 & 12278.9 & 10360.1 & 7539.5 & 816.5 & 79.81 & 69.44 & 99.16 \\
\hline 26 & 26640.1 & 13043.4 & 11303.6 & 7340.4 & 884.4 & 84.78 & 75.76 & 96.54 \\
\hline 30 & 26928.4 & 13623.6 & 12115.7 & 7039.2 & 938.5 & 88.55 & 81.20 & 92.58 \\
\hline 34 & 27300.1 & 14193.3 & 12956.0 & 6698.4 & 988.0 & 92.25 & 86.84 & 88.09 \\
\hline 38 & 27441.8 & 14517.3 & 13432.1 & 6360.5 & 1030.5 & 94.36 & 90.03 & 83.65 \\
\hline 42 & 27735.5 & 14792.2 & 13812.0 & 6035.0 & 1064.0 & 96.14 & 92.57 & 79.37 \\
\hline 46 & 27830.9 & 15037.0 & 14138.1 & 5634.3 & 1098.3 & 97.73 & 94.76 & 74.10 \\
\hline 50 & 28194.7 & 15222.5 & 14428.1 & 5356.1 & 1132.7 & 98.94 & 96.70 & 70.44 \\
\hline 54 & 28324.4 & 15331.9 & 14708.5 & 5043.5 & 1156.3 & 99.65 & 98.58 & 66.33 \\
\hline 59 & 28457.2 & 15373.3 & 14842.0 & 4682.0 & 1177.1 & 99.92 & 99.48 & 61.58 \\
\hline 62 & 28532.7 & 15385.6 & 14920.1 & 4444.6 & 1185.3 & 100.00 & 100.00 & 58.45 \\
\hline 66 & 28627.9 & 15359.4 & 14876.7 & 4175.1 & 1196.8 & 99.83 & 99.71 & 54.91 \\
\hline 70 & 28710.2 & 15294.7 & 14836.2 & 3908.3 & 1197.9 & 99.41 & 99.44 & 51.40 \\
\hline 74 & 28789.3 & 15162.3 & 14720.3 & 3696.1 & 1204.4 & 98.55 & 98.66 & 48.61 \\
\hline 78 & 28864.6 & 14889.5 & 14454.8 & 3499.4 & 1211.3 & 96.78 & 96.88 & 46.02 \\
\hline 81.8 & 28936.8 & 14628.5 & 14190.6 & 3374.9 & 1221.7 & 95.08 & 95.11 & 44.38 \\
\hline
\end{tabular}


Table 10A. Weighted usable area for bull trout, chinook salmon, steelhead trout life stages, and cover for juvenile life stages, site EC1, lower Elk Creek, 2003-Continued

\section{STEELHEAD}

\begin{tabular}{|c|c|c|c|c|c|c|c|c|}
\hline \multirow{2}{*}{$\begin{array}{c}\text { Discharge } \\
\left(\mathrm{ft}^{3} / \mathbf{s}\right)\end{array}$} & \multirow{2}{*}{$\begin{array}{c}\text { Total Area } \\
\left(\mathrm{ft}^{2}\right)\end{array}$} & \multicolumn{4}{|c|}{ Summary of Weighted Usable Area ( $\mathrm{ft}^{2} / 1000 \mathrm{ft}$ ) } & \multicolumn{3}{|c|}{ Percent of Optimum } \\
\hline & & Adult & Spawning & Juvenile & Cover & Adult & Spawning & Juvenile \\
\hline 6 & 20526.5 & 6614.8 & 4918.0 & 11554.6 & 538.3 & 42.99 & 32.96 & 85.84 \\
\hline 8 & 21757.1 & 7769.2 & 5878.7 & 12257.5 & 603.2 & 50.50 & 39.40 & 91.06 \\
\hline 9.77 & 23472.3 & 8727.6 & 6763.6 & 12856.0 & 654.5 & 56.73 & 45.33 & 95.51 \\
\hline 12 & 23874.7 & 9547.7 & 7524.5 & 13058.2 & 709.6 & 62.06 & 50.43 & 97.01 \\
\hline 14 & 24335.5 & 10256.5 & 8138.8 & 13268.6 & 766.8 & 66.66 & 54.55 & 98.57 \\
\hline 18 & 25934.0 & 11481.0 & 9368.0 & 13460.8 & 1014.3 & 74.62 & 62.79 & 100.00 \\
\hline 22 & 26323.6 & 12278.9 & 10360.1 & 12655.4 & 1162.8 & 79.81 & 69.44 & 94.02 \\
\hline 26 & 26640.1 & 13043.4 & 11303.6 & 12160.0 & 1292.3 & 84.78 & 75.76 & 90.34 \\
\hline 30 & 26928.4 & 13623.6 & 12115.7 & 11711.4 & 1406.2 & 88.55 & 81.20 & 87.00 \\
\hline 34 & 27300.1 & 14193.3 & 12956.0 & 11059.1 & 1423.2 & 92.25 & 86.84 & 82.16 \\
\hline 38 & 27441.8 & 14517.3 & 13432.1 & 10598.5 & 1513.6 & 94.36 & 90.03 & 78.74 \\
\hline 42 & 27735.5 & 14792.2 & 13812.0 & 10234.5 & 1661.3 & 96.14 & 92.57 & 76.03 \\
\hline 46 & 27830.9 & 15037.0 & 14138.1 & 9901.4 & 1730.6 & 97.73 & 94.76 & 73.56 \\
\hline 50 & 28194.7 & 15222.5 & 14428.1 & 9510.5 & 1774.3 & 98.94 & 96.70 & 70.65 \\
\hline 54 & 28324.4 & 15331.9 & 14708.5 & 8757.2 & 1802.4 & 99.65 & 98.58 & 65.06 \\
\hline 59 & 28457.2 & 15373.3 & 14842.0 & 8028.3 & 1818.3 & 99.92 & 99.48 & 59.64 \\
\hline 62 & 28532.7 & 15385.6 & 14920.1 & 7629.6 & 1797.9 & 100.00 & 100.00 & 56.68 \\
\hline 66 & 28627.9 & 15359.4 & 14876.7 & 7078.1 & 1788.7 & 99.83 & 99.71 & 52.58 \\
\hline 70 & 28710.2 & 15294.7 & 14836.2 & 6411.4 & 1786.9 & 99.41 & 99.44 & 47.63 \\
\hline 74 & 28789.3 & 15162.3 & 14720.3 & 6104.1 & 1745.1 & 98.55 & 98.66 & 45.35 \\
\hline 78 & 28864.6 & 14889.5 & 14454.8 & 5841.3 & 1738.9 & 96.78 & 96.88 & 43.39 \\
\hline 81.8 & 28936.8 & 14628.5 & 14190.6 & 5470.4 & 1723.5 & 95.08 & 95.11 & 40.64 \\
\hline
\end{tabular}


Figure 46A

Percent of Contiguous Stream Width

Lower Elk Creek - EC1

Passage Transect 1 (wide low slope)

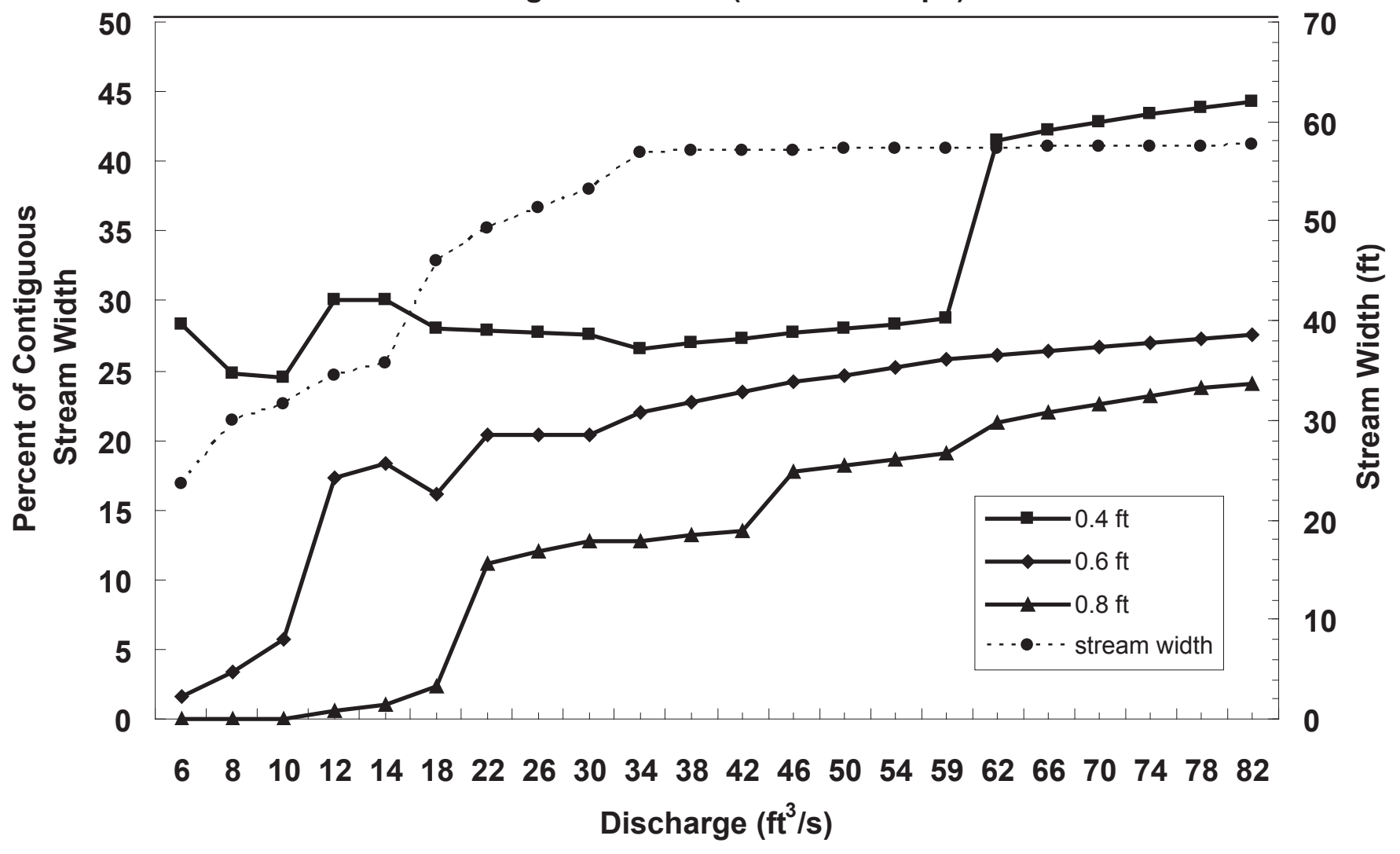

Discharge ( $\left.\mathrm{ft}^{3} / \mathrm{s}\right)$ 
Figure 47A

Percent of Total Stream Width

Lower Elk Creek - EC1

Passage Transect 1 (wide low slope)

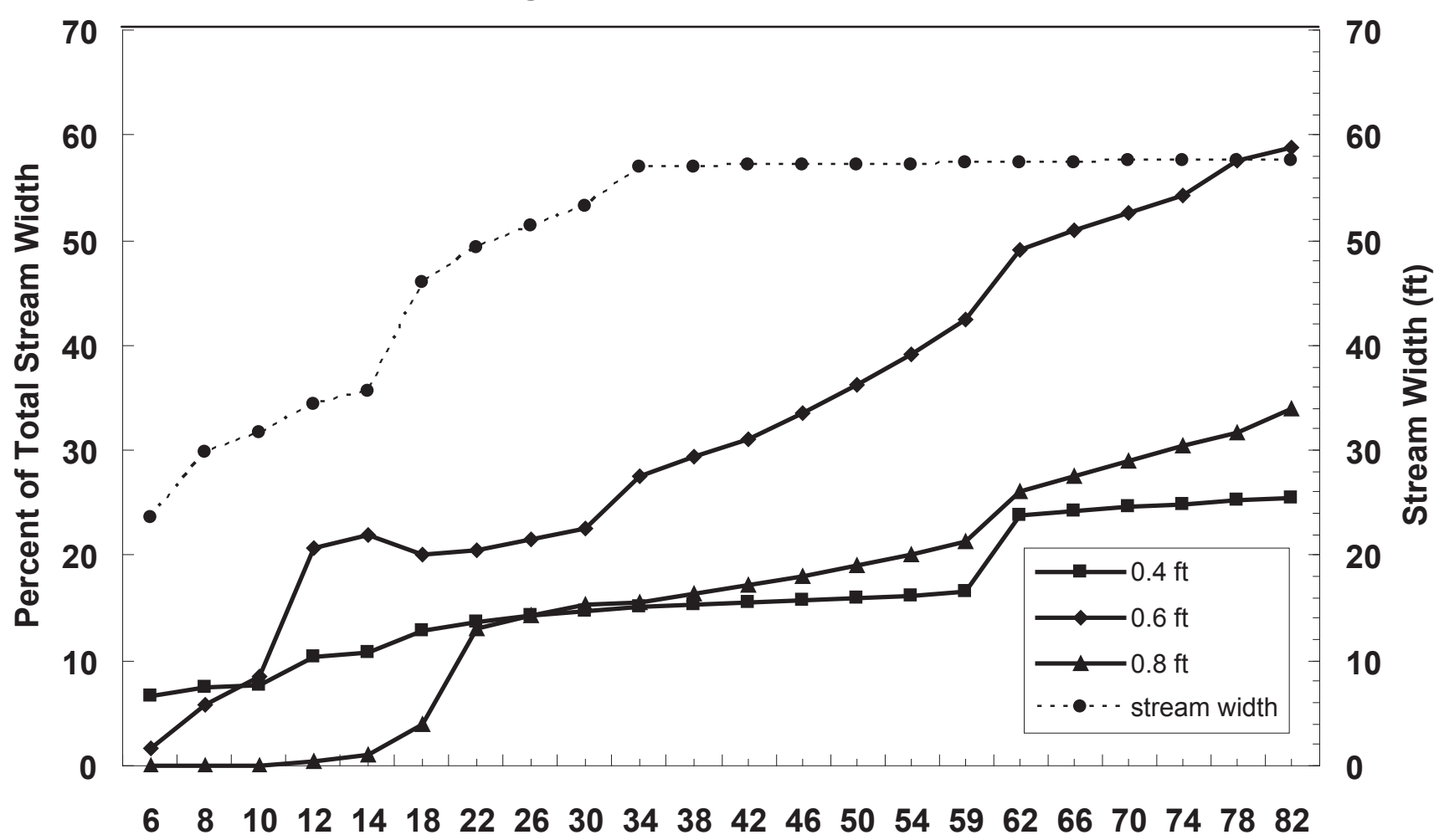

Discharge $\left(\mathrm{ft}^{3} / \mathrm{s}\right)$ 
Table 11A. Passage criteria assessment for transect 1 (wide low slope), site EC1, lower Elk Creek, 2003

\begin{tabular}{|c|c|c|c|c|c|}
\hline $\begin{array}{c}\text { Discharge } \\
\left(\mathrm{ft}^{3} / \mathrm{s}\right)\end{array}$ & $\begin{array}{c}\text { Stream width } \\
\text { (ft) }\end{array}$ & $\begin{array}{l}\text { Total Stream } \\
\text { Width Greater } \\
\text { Than } 0.4 \mathrm{ft} \text { depth }\end{array}$ & $\begin{array}{l}\text { Percent Stream } \\
\text { Width Greater } \\
\text { Than } 0.4 \mathrm{ft} \text { Depth }\end{array}$ & $\begin{array}{c}\text { Contiguous Stream } \\
\text { Width Greater Than } \\
0.4 \mathrm{ft} \text { Depth }\end{array}$ & $\begin{array}{l}\text { Percent Contiguous } \\
\text { Stream Width Greater } \\
\text { Than } 0.4 \mathrm{ft} \text { Depth }\end{array}$ \\
\hline 6 & 23.52 & 8.01 & 6.67 & 6.67 & 28.36 \\
\hline 8 & 29.89 & 9.21 & 7.41 & 7.41 & 24.79 \\
\hline 9.77 & 31.66 & 9.85 & 7.76 & 7.76 & 24.53 \\
\hline 12 & 34.46 & 10.86 & 10.37 & 10.37 & 30.10 \\
\hline 14 & 35.66 & 11.67 & 10.73 & 10.73 & 30.08 \\
\hline 18 & 45.95 & 16.53 & 12.89 & 12.89 & 28.06 \\
\hline 22 & 49.31 & 18.59 & 13.71 & 13.71 & 27.81 \\
\hline 26 & 51.33 & 21.34 & 14.22 & 14.22 & 27.70 \\
\hline 30 & 53.22 & 23.92 & 14.69 & 14.69 & 27.61 \\
\hline 34 & 56.88 & 28.93 & 15.09 & 15.09 & 26.53 \\
\hline 38 & 56.97 & 30.23 & 15.33 & 15.33 & 26.92 \\
\hline 42 & 57.06 & 31.48 & 15.57 & 15.57 & 27.29 \\
\hline 46 & 57.13 & 33.68 & 15.81 & 15.81 & 27.67 \\
\hline 50 & 57.19 & 34.52 & 16.02 & 16.02 & 28.01 \\
\hline 54 & 57.25 & 35.38 & 16.24 & 16.24 & 28.36 \\
\hline 59 & 57.33 & 36.41 & 16.50 & 16.50 & 28.77 \\
\hline 62 & 57.37 & 44.22 & 23.85 & 23.85 & 41.57 \\
\hline 66 & 57.43 & 45.21 & 24.23 & 24.23 & 42.20 \\
\hline 70 & 57.48 & 46.15 & 24.59 & 24.59 & 42.79 \\
\hline 74 & 57.53 & 47.03 & 24.94 & 24.94 & 43.35 \\
\hline 78 & 57.58 & 49.07 & 25.26 & 25.26 & 43.87 \\
\hline 81.8 & 57.63 & 50.00 & 25.50 & 25.50 & 44.26 \\
\hline $\begin{array}{c}\text { Discharge } \\
\qquad\left(\mathrm{ft}^{3} / \mathrm{s}\right)\end{array}$ & $\begin{array}{c}\text { Stream width } \\
\text { (ft) }\end{array}$ & $\begin{array}{c}\text { Total Stream } \\
\text { Width Greater } \\
\text { Than } 0.6 \text { ft Depth }\end{array}$ & $\begin{array}{l}\text { Percent Stream } \\
\text { Width Greater } \\
\text { Than } 0.6 \text { ft Depth }\end{array}$ & $\begin{array}{c}\text { Contiguous Stream } \\
\text { Width Greater Than } \\
\text { 0.6 ft Depth }\end{array}$ & $\begin{array}{l}\text { Percent Contiguous } \\
\text { Stream Width Greater } \\
\text { Than } \mathbf{0 . 6} \text { ft Depth }\end{array}$ \\
\hline 6 & 23.52 & 0.39 & 1.65 & 0.39 & 1.65 \\
\hline 8 & 29.89 & 1.74 & 5.83 & 1.02 & 3.42 \\
\hline 9.77 & 31.66 & 2.71 & 8.57 & 1.81 & 5.72 \\
\hline 12 & 34.46 & 7.11 & 20.62 & 5.98 & 17.35 \\
\hline 14 & 35.66 & 7.82 & 21.93 & 6.53 & 18.30 \\
\hline 18 & 45.95 & 9.26 & 20.14 & 7.44 & 16.19 \\
\hline 22 & 49.31 & 10.12 & 20.53 & 10.05 & 20.39 \\
\hline 26 & 51.33 & 11.11 & 21.64 & 10.48 & 20.42 \\
\hline 30 & 53.22 & 12.03 & 22.60 & 10.88 & 20.45 \\
\hline 34 & 56.88 & 15.62 & 27.46 & 12.49 & 21.96 \\
\hline 38 & 56.97 & 16.70 & 29.32 & 12.97 & 22.77 \\
\hline 42 & 57.06 & 17.74 & 31.10 & 13.43 & 23.53 \\
\hline 46 & 57.13 & 19.18 & 33.57 & 13.82 & 24.19 \\
\hline 50 & 57.19 & 20.78 & 36.33 & 14.12 & 24.68 \\
\hline 54 & 57.25 & 22.39 & 39.10 & 14.41 & 25.17 \\
\hline 59 & 57.33 & 24.35 & 42.47 & 14.77 & 25.77 \\
\hline 62 & 57.37 & 28.16 & 49.08 & 14.94 & 26.04 \\
\hline 66 & 57.43 & 29.23 & 50.90 & 15.15 & 26.37 \\
\hline 70 & 57.48 & 30.24 & 52.60 & 15.34 & 26.68 \\
\hline 74 & 57.53 & 31.19 & 54.21 & 15.52 & 26.97 \\
\hline 78 & 57.58 & 33.19 & 57.65 & 15.69 & 27.25 \\
\hline 81.8 & 57.63 & 33.87 & 58.77 & 15.86 & 27.52 \\
\hline
\end{tabular}


Table 11A. Passage criteria assessment for transect 1 (wide low slope), site EC1, lower Elk Creek, 2003 —Continued

$\begin{array}{cccccc}\begin{array}{c}\text { Discharge } \\ \left(\mathbf{f t}^{\mathbf{3}} \mathbf{/ s}\right)\end{array} & \begin{array}{c}\text { Stream width } \\ \text { (ft) }\end{array} & \begin{array}{c}\text { Total Stream } \\ \text { Width Greater } \\ \text { Than } \mathbf{0 . 8} \mathbf{f t} \text { Depth }\end{array} & \begin{array}{c}\text { Percent Stream } \\ \text { Width Greater } \\ \text { Than } \mathbf{0 . 8} \mathbf{f t} \text { Depth }\end{array} & \begin{array}{c}\text { Contiguous Stream } \\ \text { Width Greater Than } \\ \mathbf{0 . 8} \mathbf{f t} \text { Depth }\end{array} & \begin{array}{c}\text { Percent Contiguous } \\ \text { Stream Width Greater } \\ \text { Than } \mathbf{0 . 8} \text { ft Depth }\end{array} \\ 6 & 23.52 & 0.00 & 0.00 & 0.00 & 0.00 \\ 8 & 29.89 & 0.00 & 0.00 & 0.00 & 0.00 \\ 9.77 & 31.66 & 0.00 & 0.00 & 0.00 & 0.00 \\ 12 & 34.46 & 0.18 & 0.51 & 0.18 & 0.51 \\ 14 & 35.66 & 0.35 & 0.97 & 0.35 & 0.97 \\ 18 & 45.95 & 1.82 & 3.95 & 1.08 & 2.36 \\ 22 & 49.31 & 6.46 & 13.09 & 5.48 & 11.12 \\ 26 & 51.33 & 7.32 & 14.27 & 6.15 & 11.97 \\ 30 & 53.22 & 8.14 & 15.29 & 6.77 & 12.71 \\ 34 & 56.88 & 8.86 & 15.58 & 7.22 & 12.69 \\ 38 & 56.97 & 9.33 & 16.38 & 7.48 & 13.13 \\ 42 & 57.06 & 9.78 & 17.14 & 7.73 & 17.76 \\ 46 & 57.13 & 10.33 & 18.09 & 10.14 & 18.17 \\ 50 & 57.19 & 10.90 & 19.06 & 10.39 & 18.59 \\ 54 & 57.25 & 11.48 & 20.05 & 10.64 & 19.10 \\ 59 & 57.33 & 12.18 & 21.25 & 10.95 & 21.28 \\ 62 & 57.37 & 14.98 & 26.11 & 12.21 & 21.95 \\ 66 & 57.43 & 15.87 & 27.63 & 12.60 & 22.57 \\ 70 & 57.48 & 16.71 & 29.07 & 12.97 & 23.16 \\ 74 & 57.53 & 17.50 & 30.42 & 13.32 & 23.71 \\ 78 & 57.58 & 18.26 & 31.71 & 13.65 & 24.10 \\ 81.8 & 57.63 & 19.54 & 33.90 & 13.89 & \end{array}$




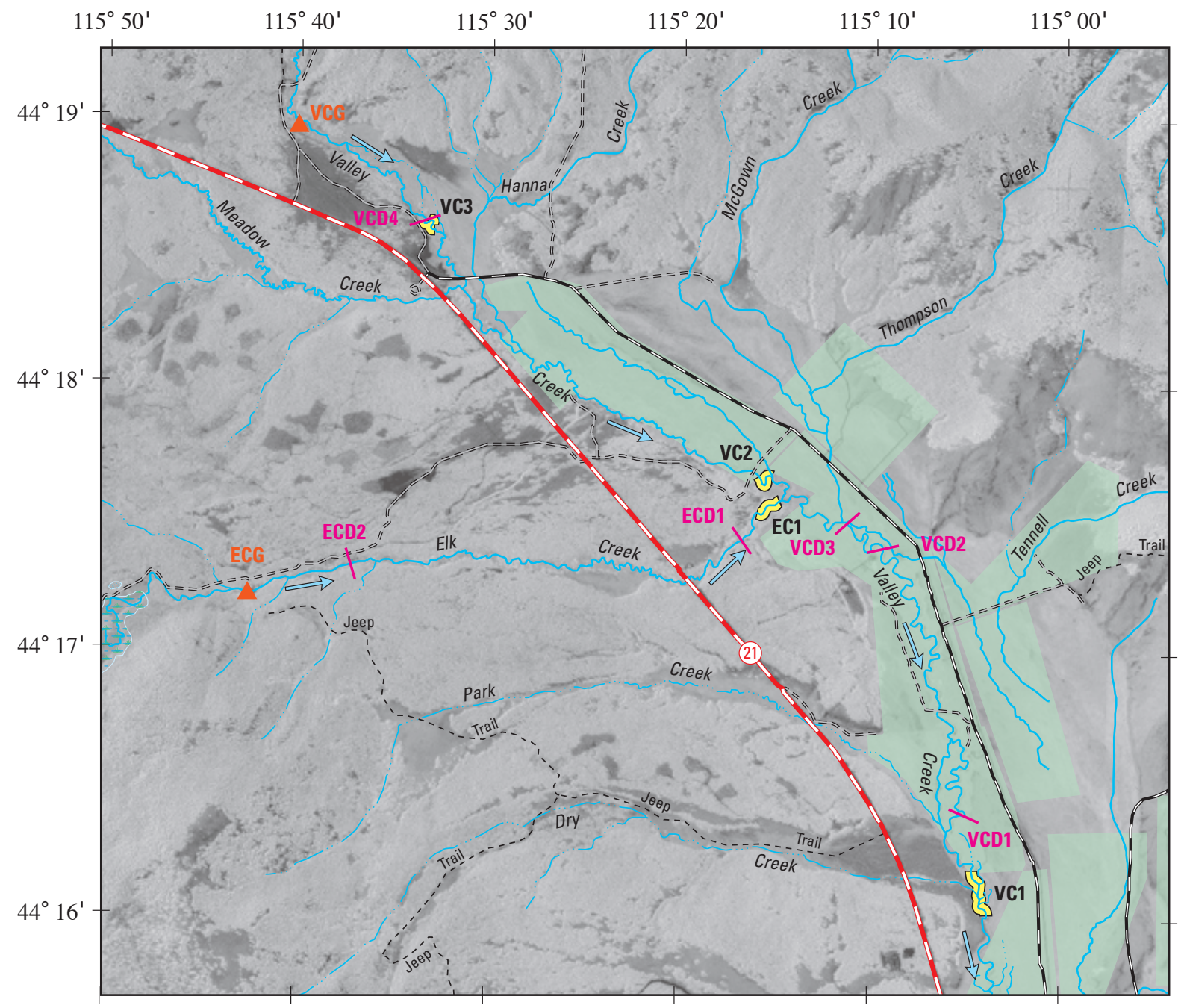

Base from U.S. Geological Survey digital data; 1998; 1:40,000,

Transverse Mercator projection; Factor at central meridian: 0.99960;

Longitude of central meridian: $-114^{\circ} 00^{\prime}$; Latitude of origin: $42^{\circ} 00^{\prime}$

False easting (meters): 500,000; False northing (meters): 100,000

Hydrography from U.S. Geological Survey; 1999; 1:24,000
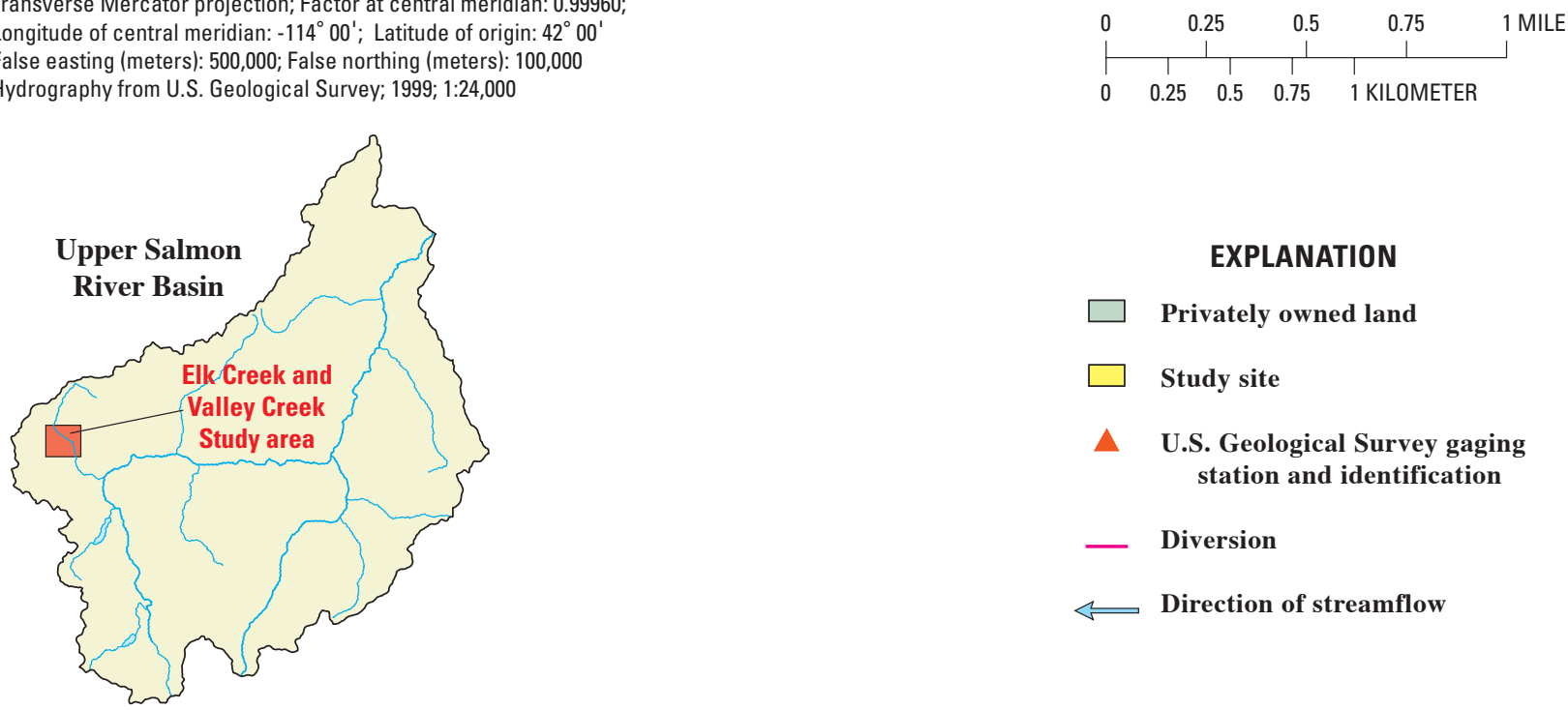

\section{EXPLANATION}

Privately owned land

Study site

- U.S. Geological Survey gaging station and identification

- Diversion

Direction of streamflow

Figure 12. Elk Creek and Valley Creek study sites, diversions, and gaging station locations, upper Salmon River Basin, Idaho, 2003 (Basin and site characteristics shown in table 1) 


\section{Valley Creek (click here for abbreviations used in figures 48 A-74A and tables 12A-17A)}

Valley Creek is located in the northwest portion of the upper Salmon River Basin and is a tributary to the Salmon River. Its headwaters originate in the peaks that separate the upper Salmon and Middle Fork Salmon drainages

(figure 1). The Valley Creek Basin covers about $148 \mathrm{mi}^{2}$, of which about 63 percent is forest. The basin has a mean elevation of about 7,320 ft above sea level and receives an average of about $24 \mathrm{in}$. of precipitation per year. As previously mentioned, a long-term USGS streamflow-gaging station (13295000) also is operated on Valley Creek at the mouth, at the town of Stanley.

\section{Hydrology During 2003}

A short-term streamflow gaging station (13294600) was installed and operated on Valley Creek during the period May 1 through October 5, 2003. The gaging station was located upstream from all active diversions, about $11.5 \mathrm{mi}$ upstream from the confluence with the Salmon River, and 2.8 mi upstream from the confluence with Elk Creek (figure 12, VCGU). Stage data were collected at 15-minute intervals and five instantaneous discharge measurements were completed. Stage-discharge relations from the instantaneous measurements were used to determine discharges at each 15-minute interval, resulting in a continuous record of streamflow. A plot of the daily mean streamflow in Valley Creek upstream from the diversions during WY03 is presented in figure 16, along with markers indicating the times when field data were collected at the study sites downstream.

Additional analyses were completed to relate streamflows in Valley Creek during WY03 to long-term mean streamflows. The same techniques used to estimate long-term streamflows for Pole Creek also were used for Valley Creek. The July, August, and September daily mean discharge hydrograph for Valley Creek upstream from diversions (13294600) for WY03 and the estimated long-term daily mean hydrograph are presented in figure 17. Also presented in figure 17 are estimated monthly streamflow statistics for the gaging station location based on regional regression equations developed by Hortness and Berenbrock (2001). Again, the median estimate gives an indication of long-term average streamflow conditions, and the other estimates provide an indication of the probable variation in streamflows at this location.

The 80-, 50-, and 20-percent monthly exceedance discharge values were estimated on the basis of WY03 daily

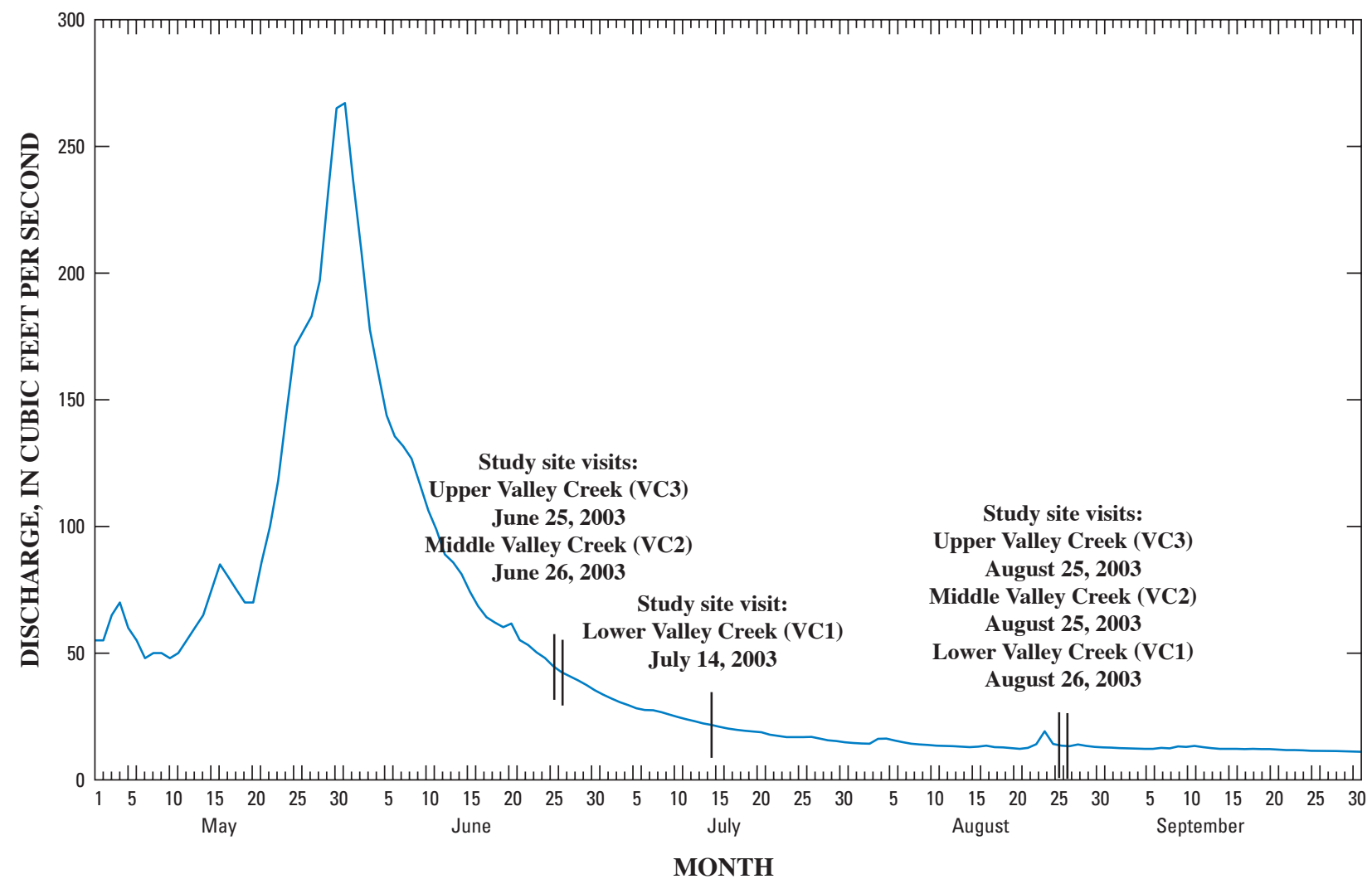

Figure 16. Daily mean discharge at Valley Creek upstream from diversions near Stanley (13294600), upper Salmon River Basin, Idaho, May 1 through September 30, 2003 


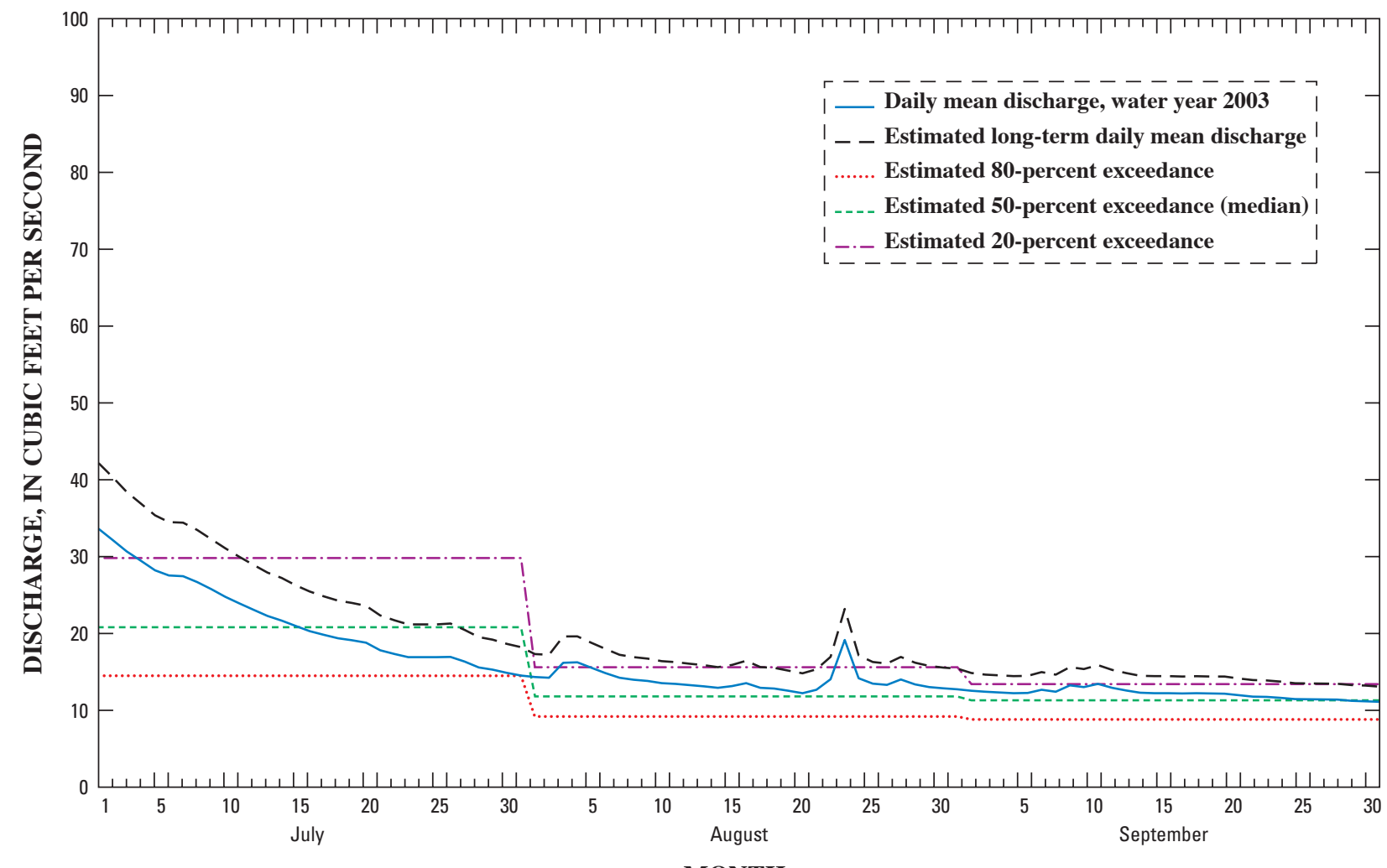

Figure 17. Daily mean discharge for water year 2003, estimated long-term daily mean discharge, and estimated 80-, 50-, and 20-percent exceedance statistics for Valley Creek upstream from diversions near Stanley (13294600), upper Salmon River Basin, Idaho, July 1 through September 30

Table 11. Calculated and estimated 80-, 50-, and 20-percent monthly exceedance discharge values for Valley Creek upstream from diversions near Stanley (13294600), upper Salmon River Basin, Idaho, 2003

[Q, discharge; values presented in cubic feet per second]

\begin{tabular}{|c|c|c|c|c|c|c|c|c|c|c|}
\hline & \multicolumn{3}{|c|}{ July } & \multicolumn{3}{|c|}{ August } & \multicolumn{3}{|c|}{ September } \\
\hline & & 0.80 & 0.50 & 0.20 & 0.80 & 0.50 & 0.20 & 0.80 & 0.50 & 0.20 \\
\hline \multirow{3}{*}{ 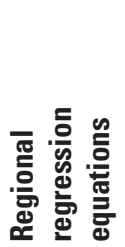 } & Water year 2003 & 16.9 & 20.3 & 27.5 & 12.9 & 13.5 & 14.2 & 11.5 & 12.2 & 12.6 \\
\hline & Upper confidence limit & 22.4 & 30.1 & 41.6 & 15.7 & 18.6 & 23.3 & 15.4 & 16.4 & 18.9 \\
\hline & Estimate & 14.5 & 20.8 & 29.8 & 9.20 & 11.8 & 15.6 & 8.80 & 11.3 & 13.4 \\
\hline
\end{tabular}

\footnotetext{
${ }^{1}$ Estimate based on comparisons between water year 2003 and long-term monthly mean discharges at Valley Creek at Stanley (13295000).
} 
mean discharge values and estimated long-term daily mean discharge values at the short-term Valley Creek gaging station (13294600) (table 11). Exceedance estimates, along with the confidence limits, also were derived from the regional regression equations (Hortness and Berenbrock, 2001) for this location (table 11). Comparison between the estimated long-term daily mean discharge values and values calculated on the basis of the regression equations can provide some insight as to the applicability of the regression equations for Valley Creek. As was apparent in figure 17, the regression estimates tend to be slightly lower than the estimated long-term values, indicating that the equations, to some degree, could underestimate streamflow conditions in Valley Creek.

Although seepage analyses were not within the scope of this project, instantaneous discharge measurements provide some indication of the amount of streamflow being diverted at specific times during the study period. A summary of discharge measured in Valley Creek during the study period is presented in table 12 .

\section{Habitat Modeling and Passage Results}

Upper Valley Creek (VC3) discharges required for maximum WUA ranged from 13 to $29 \mathrm{ft}^{3} / \mathrm{s}, 9$ to $40 \mathrm{ft}^{3} / \mathrm{s}$, and 15 to $37 \mathrm{ft}^{3} / \mathrm{s}$ for bull trout, chinook salmon, and steelhead trout life stages, respectively (table 13). Pool habitat made up about 6 percent of the stream segment surveyed, indicating this stream may have limited juvenile rearing habitat. Discharges required for passage over shallow riffle habitat ranged from 15 to $8 \mathrm{ft}^{3} / \mathrm{s}$ for the depth criterion of $0.6 \mathrm{ft}$ over 25 percent of the total channel width and over 10 percent of the contiguous channel width, respectively (see transect 2 photo at http://id.water.usgs.gov/projects/salmon_streamflow). For more information summarizing the results of this study, see the appendices, figure $48 \mathrm{~A}$, figure $49 \mathrm{~A}$, figure $50 \mathrm{~A}$, figure $51 \mathrm{~A}$, figure $52 \mathrm{~A}$, figure $53 \mathrm{~A}$, figure $54 \mathrm{~A}$, figure $55 \mathrm{~A}$, and figure $56 \mathrm{~A}$, and table $12 \mathrm{~A}$ and table $13 \mathrm{~A}$.

Table 12. Miscellaneous discharge measurements collected on Valley Creek, upper Salmon River Basin, Idaho, 2003

[Basin and site characteristics shown in table 1; locations shown in figure 12; VCGU, Valley Creek at U.S. Geological Survey gage; VC3, Upper Valley Creek; VC2, Middle Valley Creek; VC1, Lower Valley Creek; VCGL, Valley Creek at lower U.S. Geological Survey gage; values presented in cubic feet per second; - , no data available]

\begin{tabular}{crrrcc}
\hline Date & VCGU & VC3 & VC2 & VC1 & VCGL $^{1}$ \\
\hline $6 / 25 / 03$ & $\underline{44.9}$ & 39.4 & - & - & $\underline{381}$ \\
$6 / 26 / 03$ & $\underline{42.5}$ & - & 78.5 & - & $\underline{355}$ \\
$7 / 14 / 03$ & $\underline{21.7}$ & - & - & 68.8 & $\underline{206}$ \\
$7 / 31 / 03$ & $\underline{14.5}$ & - & - & - & $\underline{114}$ \\
$8 / 25 / 03$ & $\underline{13.5}$ & 7.70 & 20.3 & - & 85.6 \\
$8 / 26 / 03$ & $\underline{13.3}$ & - & - & 31.4 & $\underline{85.2}$ \\
\hline
\end{tabular}

${ }^{1}$ Daily mean discharge values are underlined.
According to Munther (1974), Valley Creek is one of the SNRA's most heavily utilized spawning streams for chinook salmon and steelhead trout. However, some portions of Valley Creek and its tributaries are dewatered partially during the peak irrigation season as a result of diversions.

Summer (July through September) discharges for VC3 were calculated on the basis of regression equations and are listed in table 13. Median discharge (Q.50) estimates for the months of July, August, and September are 19.0, 11.5, and $11.2 \mathrm{ft}^{3} / \mathrm{s}$, respectively. The mean annual discharge estimate is $29.7 \mathrm{ft}^{3} / \mathrm{s}$. As indicated earlier, on the basis of WY03 data, the regression equations might, to some degree, underestimate streamflow for Valley Creek. Adjustments to these estimates would be possible on the basis of comparison information provided in figure 17 and table 11 . However, any adjustments would be somewhat crude, because they would be based on only 1 partial year of streamflow data.

Middle Valley Creek (VC2) discharges required for maximum WUA ranged from 36 to $84 \mathrm{ft}^{3} / \mathrm{s}, 24$ to $84 \mathrm{ft}^{3} / \mathrm{s}$, and 36 to $84 \mathrm{ft}^{3} / \mathrm{s}$ for bull trout, chinook salmon, and steelhead trout life stages, respectively. Pool habitat made up about 6 percent of the stream segment surveyed, indicating this stream may have limited juvenile rearing habitat. Discharges required for passage over shallow riffle habitat were both $15 \mathrm{ft}^{3} / \mathrm{s}$ for the depth criterion of $0.6 \mathrm{ft}$ over 25 percent of the total channel width and over 10 percent of the contiguous channel width (see transect 2 photo at http://id.water.usgs.gov/projects/salmon streamflow). For more information summarizing the results of this study, see the appendices, figure 57A, figure 58A, figure $59 \mathrm{~A}$, figure $60 \mathrm{~A}$, figure $61 \mathrm{~A}$, figure $62 \mathrm{~A}$, figure $63 \mathrm{~A}$, figure $64 \mathrm{~A}$, and figure $65 \mathrm{~A}$, and table $14 \mathrm{~A}$ and table $15 \mathrm{~A}$.

Maximum WUA estimates determined by Utah State University in 1999 (M. Combs, Utah State University, written commun., 2003) at this same study site (VC2) were compared with maximum WUA estimates in this study. The University's WUA estimates ranged from 9 to $44 \mathrm{ft}^{3} / \mathrm{s}, 11$ to $70 \mathrm{ft}^{3} / \mathrm{s}$, and 21 to $70 \mathrm{ft}^{3} / \mathrm{s}$ for bull trout, chinook salmon, and steelhead trout, respectively, for the same three life stages. Generally, these maximum WUA estimates were lower than estimates in this study. The reason(s) for these lower ranges of maximum WUA estimates could not be estimated because the University's study is unpublished.

Median discharge (Q.50) estimates, based on regression equations, for the months of July, August, and September are $32.9,17.9$, and $17.9 \mathrm{ft}^{3} / \mathrm{s}$, respectively. The mean annual discharge estimate is $48.2 \mathrm{ft}^{3} / \mathrm{s}$ (table 13).

Lower Valley Creek (VC1) discharges required for maximum WUA ranged from 23 to $75 \mathrm{ft}^{3} / \mathrm{s}, 20$ to $69 \mathrm{ft}^{3} / \mathrm{s}$, and 23 to $69 \mathrm{ft}^{3} / \mathrm{s}$ for bull trout, chinook salmon, and steelhead trout life stages, respectively. Pool habitat made up about 5 percent of the stream segment surveyed, indicating this stream may have limited juvenile rearing habitat. Discharges required for passage over shallow riffle habitat ranged from 50 to $16 \mathrm{ft}^{3} / \mathrm{s}$ for the depth criterion of $0.6 \mathrm{ft}$ over 25 percent of the total channel width and over 10 percent of the contiguous channel width, 
Table 13. Habitat and discharge measurements for upper (VC3), middle (VC2), and lower (VC1) Valley Creek, upper Salmon River Basin, Idaho, 2003

[WUA, weighted usable area; $\mathrm{ft}^{3} / \mathrm{s}$, cubic feet per second. WUA maximum discharge estimates were based on Physical Habitat Simulation Model output; Q.xx, daily discharge exceeded xx percent of the time during the specified month, in $\mathrm{ft}^{3} / \mathrm{s}$; Qa, mean annual discharge, in $\mathrm{ft}^{3} / \mathrm{s}$; ND, not determined]

\begin{tabular}{|c|c|c|c|c|c|c|c|c|c|c|c|c|c|c|c|}
\hline \multirow[b]{3}{*}{ Life stage } & \multicolumn{3}{|c|}{$\begin{array}{l}\text { Discharge, in } \mathrm{ft}^{3} / \mathrm{s} \\
\text { required for maximum WUA }\end{array}$} & \multicolumn{2}{|c|}{$\begin{array}{l}\text { Discharge required for } \\
\text { adult salmonid passage } \\
\text { using } 0.6 \text { foot depth } \\
\text { criterion }\end{array}$} & \multicolumn{9}{|c|}{ Statistical summary of discharge ${ }^{2}$} & \multirow[b]{3}{*}{ Qa } \\
\hline & \multirow[b]{2}{*}{$\begin{array}{l}\text { Bull } \\
\text { trout }\end{array}$} & \multirow[b]{2}{*}{$\begin{array}{l}\text { Chinook } \\
\text { salmon }\end{array}$} & \multirow[b]{2}{*}{$\begin{array}{c}\text { Steelhead } \\
\text { trout }\end{array}$} & \multirow{2}{*}{$\begin{array}{c}\text { Over } 25 \\
\text { percent of } \\
\text { total chan- } \\
\text { nel width }\end{array}$} & \multirow{2}{*}{$\begin{array}{c}\text { Over } 10 \\
\text { percent of } \\
\text { contiguous } \\
\text { channel } \\
\text { width }\end{array}$} & \multicolumn{3}{|c|}{ July } & \multicolumn{3}{|c|}{ August } & \multicolumn{3}{|c|}{ September } & \\
\hline & & & & & & 0.80 & 0.50 & 0.20 & 0.80 & 0.50 & 0.20 & 0.80 & 0.50 & 0.20 & \\
\hline \multicolumn{16}{|c|}{ Upper Valley Creek (VC3) } \\
\hline Adult & 13 & 33 & 33 & 15 & 8 & 14.0 & 19.9 & 28.4 & 9.0 & 11.5 & 15.2 & 8.7 & 11.2 & 13.2 & 29.7 \\
\hline Spawning & 29 & 40 & 37 & ND & ND & & & & & & & & & & \\
\hline Juvenile & 13 & 9 & 15 & ND & ND & & & & & & & & & & \\
\hline \multicolumn{16}{|c|}{ Middle Valley Creek (VC2) } \\
\hline Adult & 36 & 84 & 84 & 15 & 15 & 22.0 & 32.9 & 47.6 & 13.8 & 17.9 & 23.8 & 14.1 & 17.9 & 21.3 & 48.2 \\
\hline Spawning & 84 & 84 & 84 & ND & ND & & & & & & & & & & \\
\hline Juvenile & 36 & 24 & 36 & ND & ND & & & & & & & & & & \\
\hline \multicolumn{16}{|c|}{ Lower Valley Creek (VC1) } \\
\hline Adult & 29 & 69 & 69 & 50 & 16 & 39.0 & 60.6 & 89.5 & 23.7 & 31.5 & 42.3 & 24.1 & 31.0 & 37.2 & 84.9 \\
\hline Spawning & 75 & 69 & 69 & ND & ND & & & & & & & & & & \\
\hline Juvenile & 23 & 20 & 23 & ND & ND & & & & & & & & & & \\
\hline
\end{tabular}

${ }^{1}$ Passage criterion from Thompson (1972) and Scott and others (1981); depth over both width measurements must be met to ensure passage.

${ }^{2}$ Discharge statistics derived from regional regression equations using basin and climatic characteristics (Hortness and Berenbrock, 2001).

respectively. This transect represented an exceptionally shallow, wide, low-slope riffle (see transect 4 photo at

\section{http://id.water.usgs.gov/projects/salmon_streamflow).}

For more information summarizing the results of this study, see appendices, figure 66A, figure 67A, figure 68A,

figure $69 \mathrm{~A}$, figure $70 \mathrm{~A}$, figure $71 \mathrm{~A}$, figure $72 \mathrm{~A}$, figure $73 \mathrm{~A}$, and figure $74 \mathrm{~A}$, and table $16 \mathrm{~A}$ and table $17 \mathrm{~A}$.

Median discharge (Q.50) estimates for the months of July, August, and September are 60.6, 31.5, and $31.0 \mathrm{ft}^{3} / \mathrm{s}$, respectively. The mean annual discharge estimate is $84.9 \mathrm{ft}^{3} / \mathrm{s}$ (table 13).

In addition to the PHABSIM modeling for the lower Valley Creek site, an analysis was completed on a side channel located between transects 3 and 4 (see appendices, figure 66A). This was the only study site where side channel habitat made up a significant portion ( $>10$ percent) of the stream segment assessed. During the first site visit (July 25, 2003), when the measured discharge was equal to $68.8 \mathrm{ft}^{3} / \mathrm{s}$, the side channel was approximately $370 \mathrm{ft}$ long and $14 \mathrm{ft}$ wide. The average water depth at that time was approximately $0.3 \mathrm{ft}$ and the average water velocity was less than $0.2 \mathrm{ft} / \mathrm{s}$. Analysis of the inlet and outlet portions of the side channel revealed that a discharge of approximately $150 \mathrm{ft}^{3} / \mathrm{s}$ would be required to allow for a minimum passage depth of $0.4 \mathrm{ft}$. Because it is highly unlikely that natural discharges at this site during the months of July, August, and September would exceed 150 $\mathrm{ft}^{3} / \mathrm{s}$, this side channel likely does not contain suitable fish habitat during those months. In addition, no fish were observed during the initial site visit in July.

\section{Stream Temperature Results}

Five data loggers were deployed in Valley Creek in late June (figure 12). Two data loggers were deployed in upper Valley Creek-one at the USGS short-term gaging station (VCGU) upstream from all diversions and the other at the PHABSIM study site VC3 downstream from VCGU. Another data logger was deployed in middle Valley Creek at the PHABSIM study site VC2. Two additional data loggers were deployed in lower Valley Creek; one at PHABSIM study site $\mathrm{VC} 1$ and one at the USGS long-term gaging station at the mouth of Valley Creek (see figure 1). Data loggers were retrieved in late September. Of the five data loggers deployed, 
four were retrieved. Upon retrieval, the data logger deployed at the long-term gaging station was found to have been vandalized, so no stream temperature record was obtained for that location. After the data were downloaded, June 19 through September 29 (103 days) was selected as the period of record for calculating stream temperature metrics for VCG, VC3, and VC2. The data logger at VC1 was found above the water surface during a site visit on July 14, at which time it was moved to a deeper location. Upon inspection of the temperature record for $\mathrm{VC} 1$, it was determined that the data logger had been exposed repeatedly to air temperatures soon after deployment until it was moved on July 14. Consequently, the stream temperature record for $\mathrm{VC} 1$ comprises a 77 -day period from July 15 through September 29.

Analysis of the stream temperature metrics for Valley Creek indicated that most of the time, there is a slight cooling trend from VCG to VC3, and then a gradual warming trend downstream from VC3 to VC1 (figure 18). In 2003, the difference in MDMT between $\mathrm{VC} 3$ and $\mathrm{VC} 1$ on any given day was less than $2.0^{\circ} \mathrm{C} 74$ percent (57 of 77 days) of the time; the maximum difference in MDMT was $3.2^{\circ} \mathrm{C}$. This warming trend most likely is due to a combination of factors, including natural heat flux, lack of riparian shading along Valley Creek, and, possibly, the diversion of streamflow for irrigation. This increase in stream temperature over the distance between VC3 and VC1 was not considered significant enough in 2003 to warrant further analysis by applying the SSTEMP model.

Results of the individual metric calculations showed that the MDMT ranged from $20.1^{\circ} \mathrm{C}$ at VC2 to $20.3^{\circ} \mathrm{C}$ at VCG. The MDMT at all sites was below the $21.0^{\circ} \mathrm{C}$ threshold that, according to Poole and others (2001), can create a thermal barrier that would block adult chinook salmon from migrating to their spawning grounds. The MDMT exceeded $18.0^{\circ} \mathrm{C}$ in July and August at all Valley Creek sites, indicating that there may be limited bull trout habitat and blocked passage as a result of high water temperatures (J. Dunham, U.S. Forest Service, written commun., 2004). No stream temperatures in Valley Creek exceeded the IDEQ $19.0^{\circ} \mathrm{C}$ MDAT and $22.0^{\circ} \mathrm{C}$ MDMT criteria for the protection of coldwater biota during the period of record. A summary of all individual temperature metrics for all study sites can be accessed at http:/|id.water.usgs.gov| projects/salmon_streamflow.

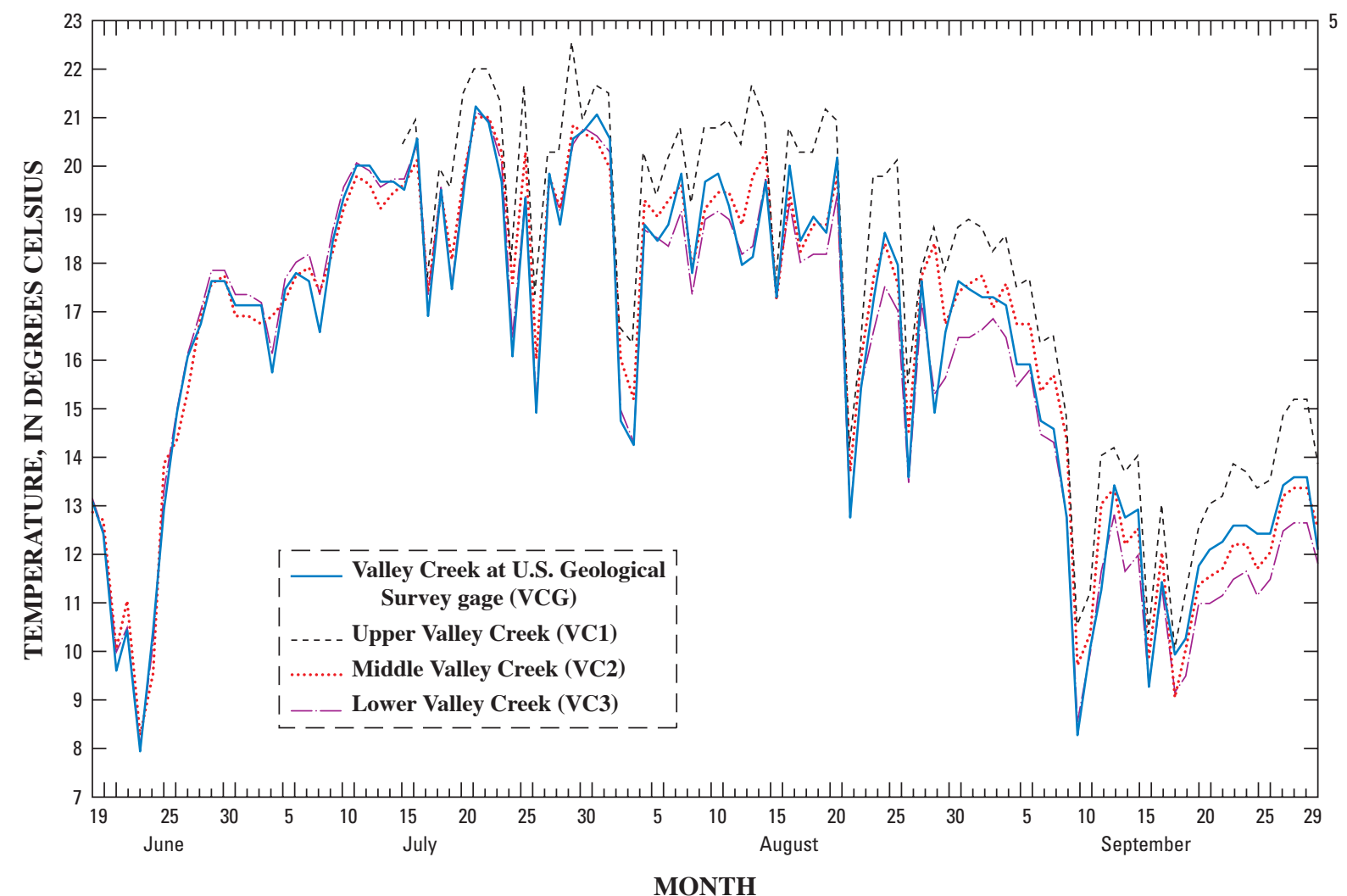

Figure 18. Maximum daily water temperature for period June 19 through September 29, 2003, at Valley Creek, upper Salmon River Basin, Idaho (site VC1 period July 15 through September 29, 2003) 


\section{Valley Creek Appendix Abbreviations}

Contiguous, continuous width with equal or greater water depth

Discharge, in $\mathrm{ft}^{3} / \mathrm{s}$

$\mathrm{ft}$, feet

$\mathrm{ft}^{2}$, square feet

$\mathrm{ft}^{3} / \mathrm{s}$, cubic feet per second

VC3, site number (see table 1)

RM1, local reference mark

Stream width, in $\mathrm{ft}$

$\mathrm{T} 1$, transect number

Total Area, study site area, in $\mathrm{ft}^{2}$

WUA, weighted usable area, in $\mathrm{ft}^{2}$ per $1,000 \mathrm{ft}$ of stream 


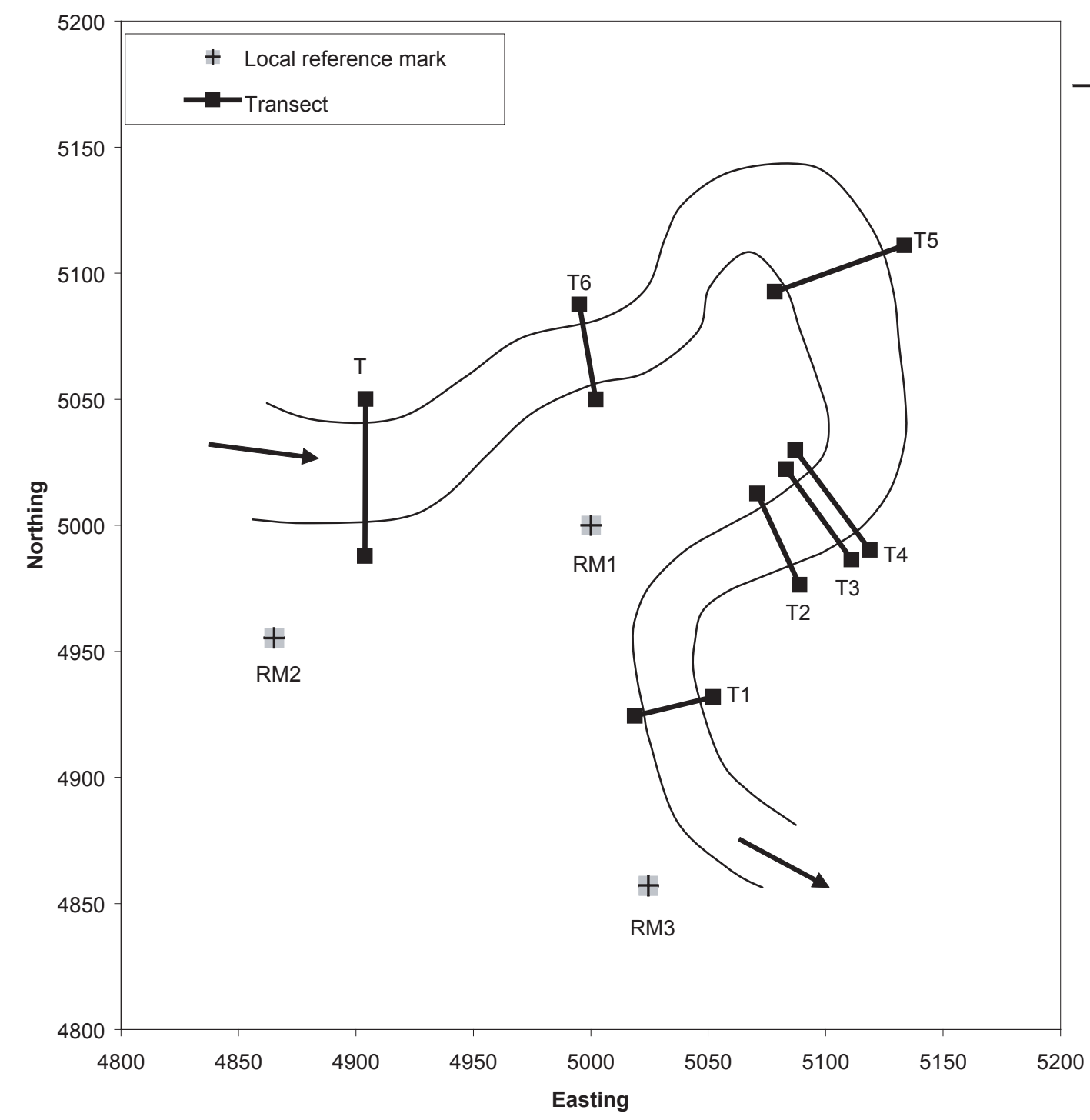

Transect Endpoint Coordinates (NAD 83)

\begin{tabular}{|c|c|c|}
\hline Point & Latitude & Longitude \\
\hline LB T1 & $115^{\circ} 3^{\prime} 19.34^{\prime \prime} \mathrm{W}$ & $44^{\circ} 18^{\prime} 34.74^{\prime \prime} \mathrm{N}$ \\
\hline RB T1 & $115^{\circ} 3^{\prime} 18.89^{\prime \prime} \mathrm{W}$ & $44^{\circ} 18^{\prime} 34.83^{\prime \prime} \mathrm{N}$ \\
\hline LB T2 & $115^{\circ} 3^{\prime} 18.69^{\prime \prime} \mathrm{W}$ & $44^{\circ} 18^{\prime} 35.63^{\prime \prime} \mathrm{N}$ \\
\hline RB T2 & $115^{\circ} 3^{\prime} 18.42^{\prime \prime} \mathrm{W}$ & $44^{\circ} 18^{\prime} 35.29^{\prime \prime} \mathrm{N}$ \\
\hline LB T3 & $115^{\circ} 3^{\prime} 18.53^{\prime \prime} \mathrm{W}$ & $44^{\circ} 18^{\prime} 35.73^{\prime \prime} \mathrm{N}$ \\
\hline RB T3 & $115^{\circ} 3^{\prime} 18.12^{\prime \prime} \mathrm{W}$ & $44^{\circ} 18^{\prime} 35.40^{\prime \prime} \mathrm{N}$ \\
\hline LB T4 & $115^{\circ} 3^{\prime} 18.48^{\prime \prime} \mathrm{W}$ & $44^{\circ} 18^{\prime} 35.81^{\prime \prime} \mathrm{N}$ \\
\hline RB T4 & $115^{\circ} 3^{\prime} 18.02^{\prime \prime ~ W}$ & $44^{\circ} 18^{\prime} 35.44^{\prime \prime} \mathrm{N}$ \\
\hline LB T5 & $115^{\circ} 3^{\prime} 18.64^{\prime \prime} \mathrm{W}$ & $44^{\circ} 18^{\prime} 36.42^{\prime \prime} \mathrm{N}$ \\
\hline RB T5 & $115^{\circ} 3^{\prime} 17.90^{\prime \prime ~ W}$ & $44^{\circ} 18^{\prime} 36.64^{\prime \prime} \mathrm{N}$ \\
\hline LB T6 & $115^{\circ} 3^{\prime} 19.66^{\prime \prime} \mathrm{W}$ & $44^{\circ} 18^{\prime} 35.97^{\prime \prime} \mathrm{N}$ \\
\hline RB T6 & $115^{\circ} 3^{\prime} 19.78^{\prime \prime} \mathrm{W}$ & $44^{\circ} 18^{\prime} 36.33^{\prime \prime} \mathrm{N}$ \\
\hline LB T7 & $115^{\circ} 3^{\prime} 20.96 " \mathrm{~W}$ & $44^{\circ} 18^{\prime} 35.30^{\prime \prime} \mathrm{N}$ \\
\hline RB T7 & $115^{\circ} 3^{\prime} 21.00^{\prime \prime ~ W}$ & $44^{\circ} 18^{\prime} 35.92^{\prime \prime} \mathrm{N}$ \\
\hline
\end{tabular}

For reference only; stream schematic not to scale. 
Figure 49A

Upper Valley Creek - VC3

Bull Trout WUA

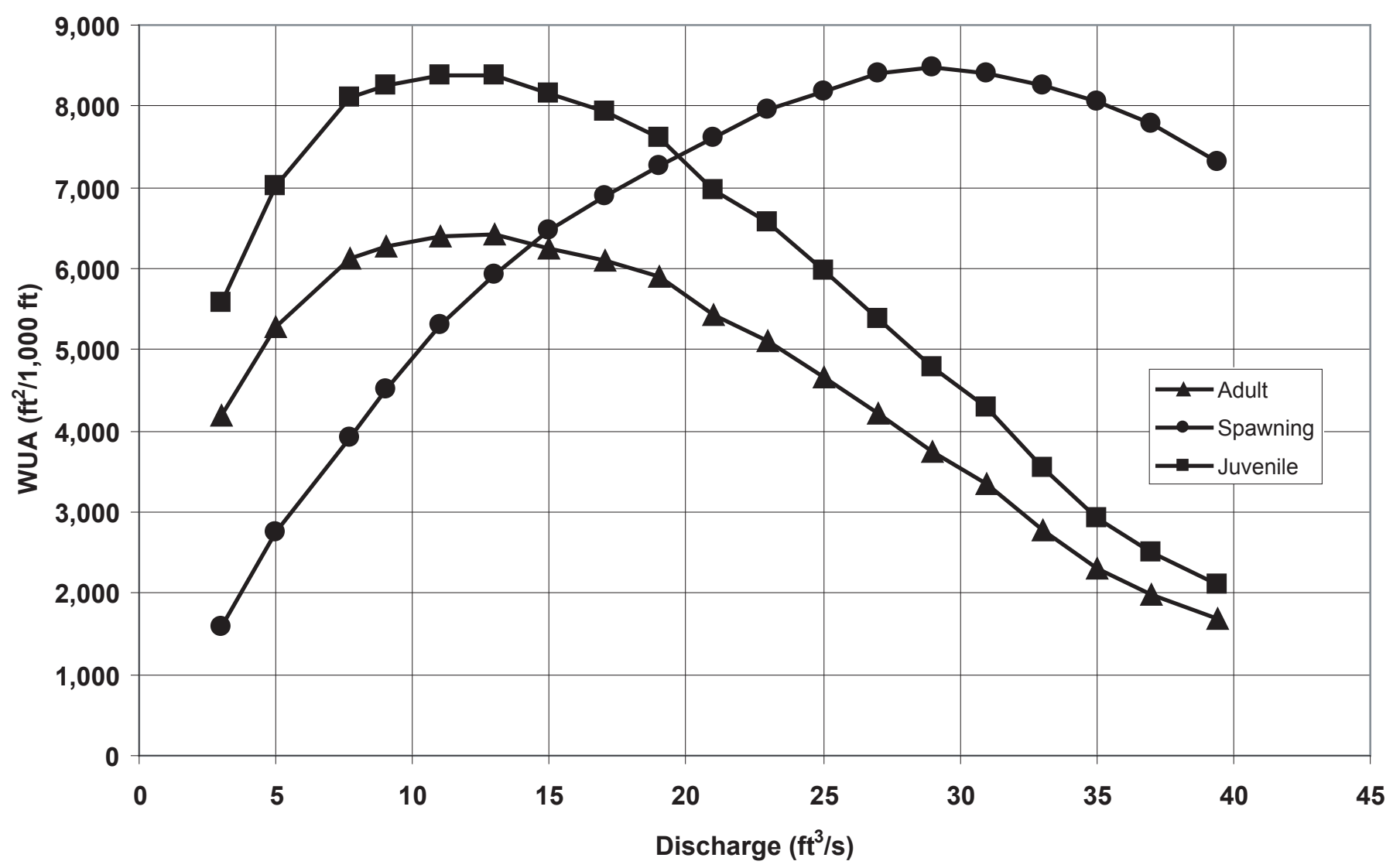

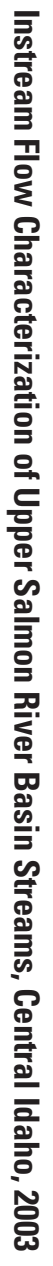


Figure 50A

Upper Valley Creek - VC3

Bull Trout WUA Normalized

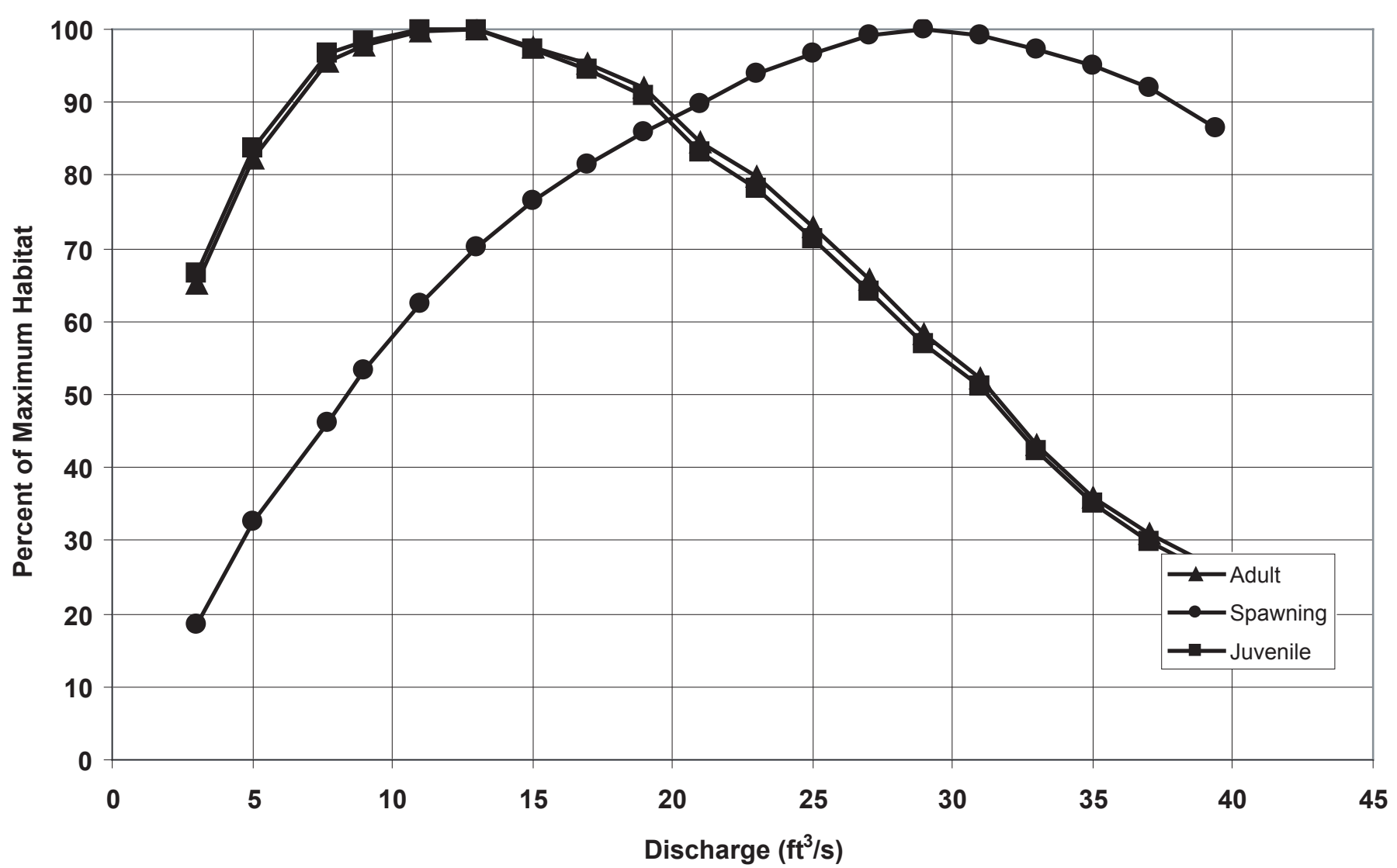


Figure 51A

Upper Valley Creek - VC3

Chinook Salmon WUA

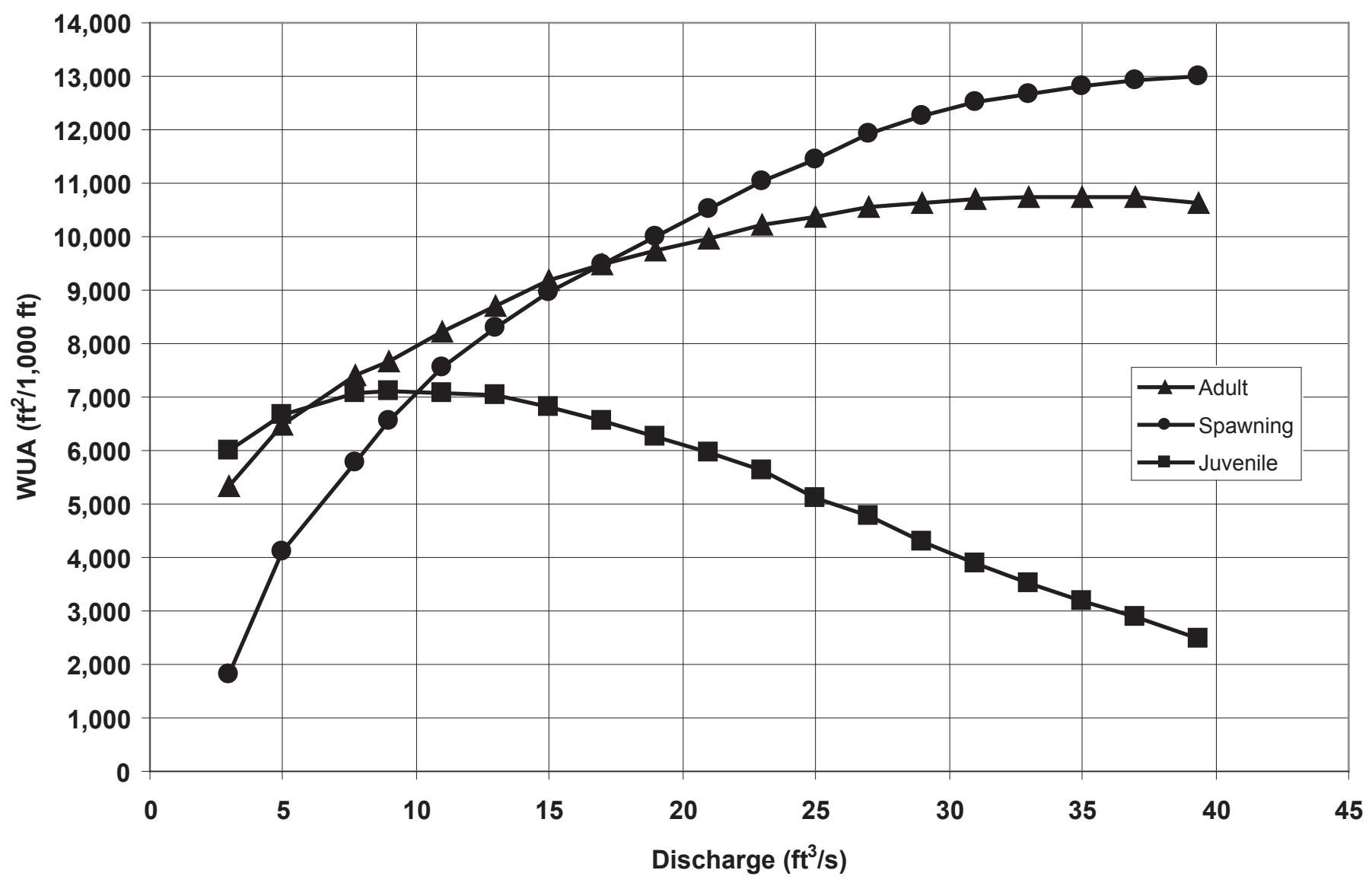

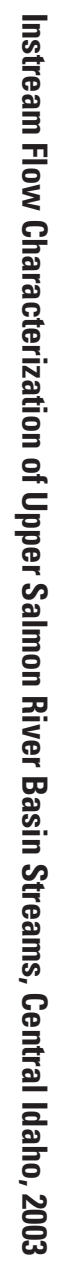


Figure 52A

Upper Valley Creek - VC3

Chinook Salmon WUA Normalized

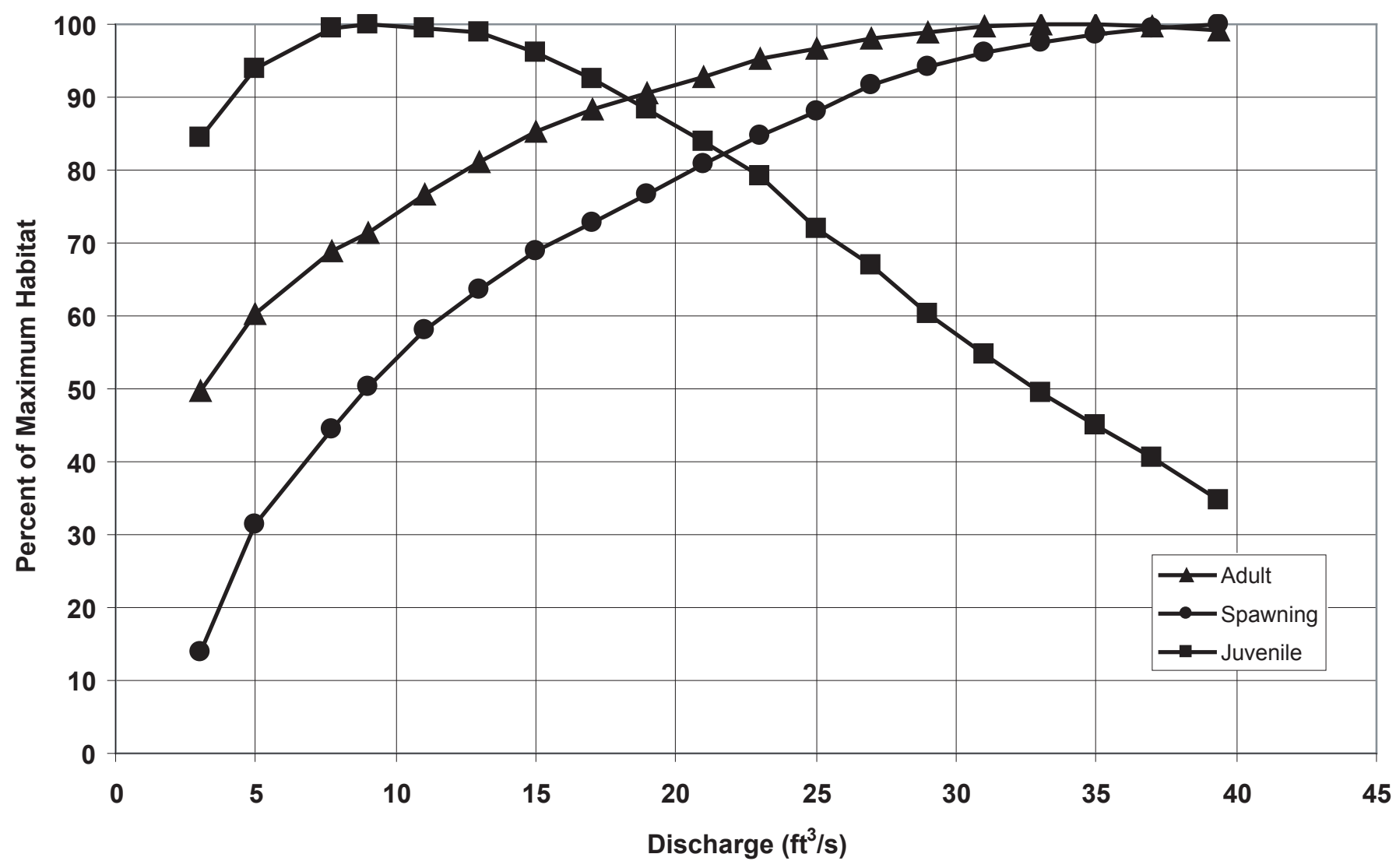


Figure 53A

Upper Valley Creek - VC3

Steelhead WUA

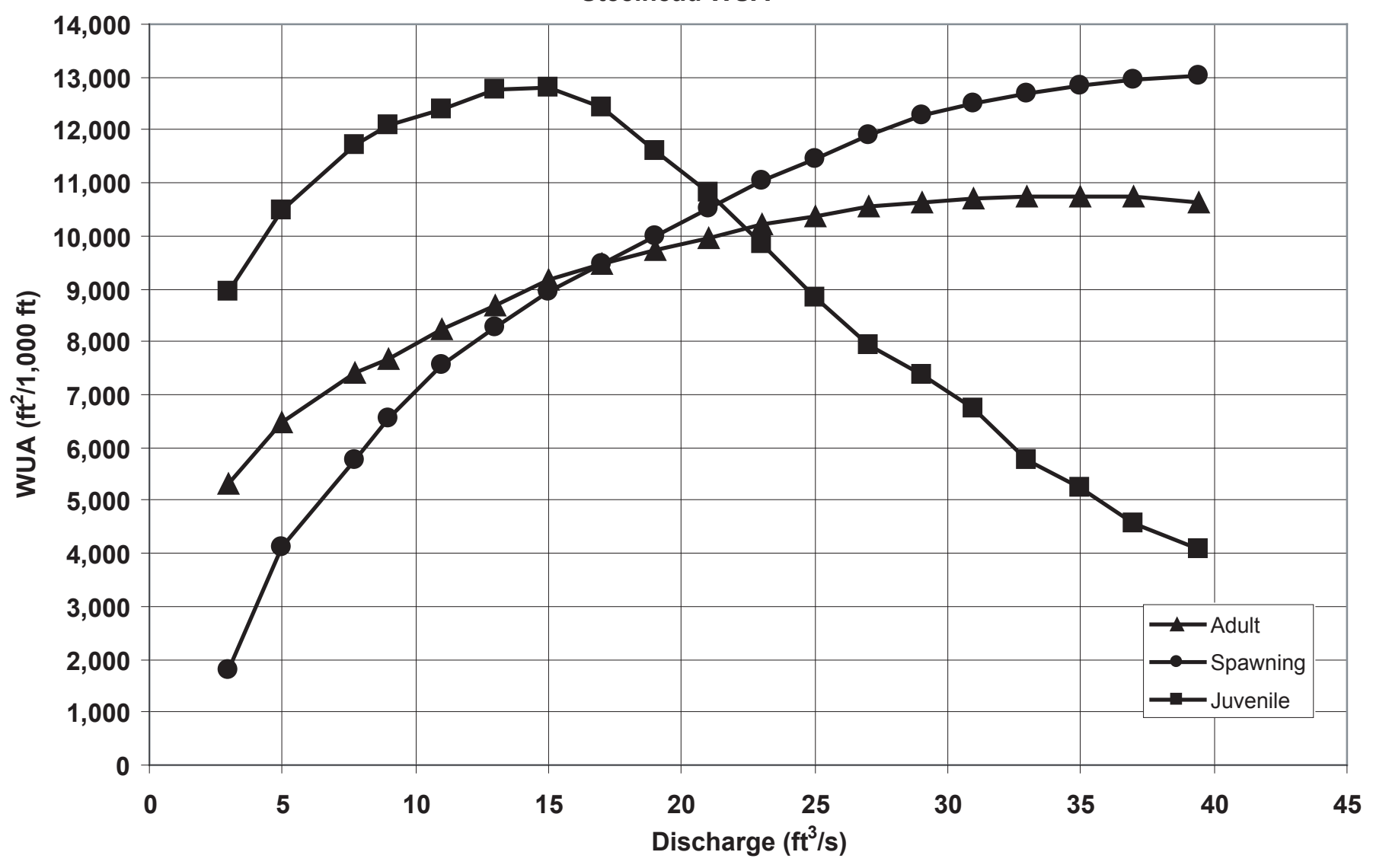


Figure 54A

Upper Valley Creek - VC3

Steelhead WUA Normalized

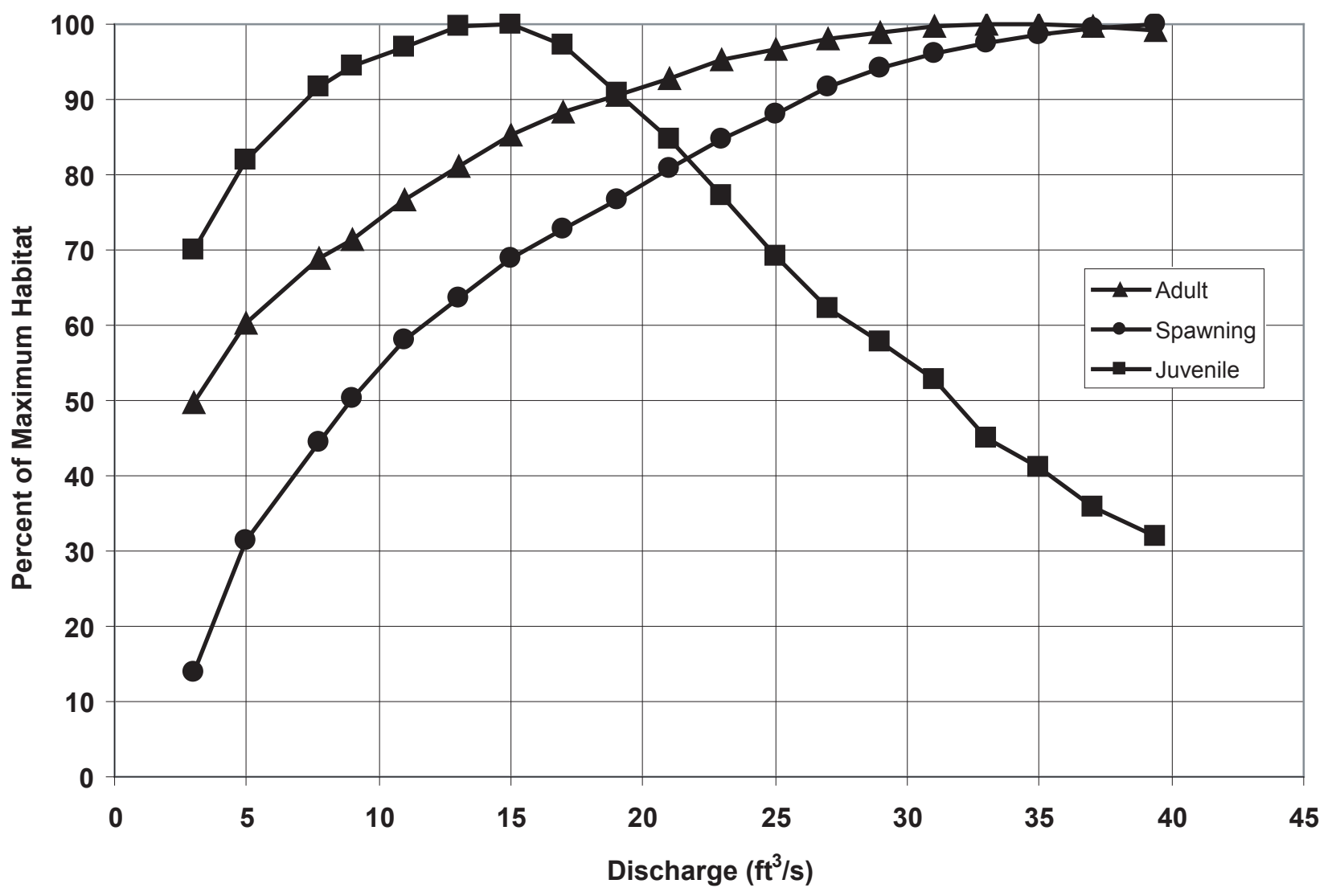

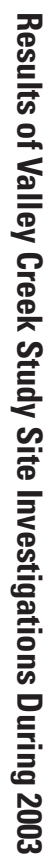


Table 12A. Weighted usable area for bull trout, chinook salmon, steelhead trout life stages, and cover for juvenile life stages, site VC3, upper Valley Creek, 2003

\section{BULL TROUT}

\begin{tabular}{|c|c|c|c|c|c|c|c|c|}
\hline \multirow{2}{*}{$\begin{array}{c}\text { Discharge } \\
\left(\mathrm{ft}^{3} / \mathrm{s}\right)\end{array}$} & \multirow{2}{*}{$\begin{array}{c}\text { Total Area } \\
\left(\mathrm{ft}^{2}\right)\end{array}$} & \multicolumn{4}{|c|}{ Summary of Weighted Usable Area $\left(\mathrm{ft}^{2} / 1000 \mathrm{ft}\right)$} & \multicolumn{3}{|c|}{ Percent of Optimum } \\
\hline & & Adult & Spawning & Juvenile & Cover & Adult & Spawning & Juvenile \\
\hline 3 & 15030.6 & 4181.0 & 1574.7 & 5585.4 & 213.9 & 65.22 & 18.59 & 66.61 \\
\hline 5 & 16259.8 & 5281.3 & 2763.9 & 7018.0 & 232.2 & 82.39 & 32.63 & 83.69 \\
\hline 7.7 & 17150.8 & 6133.6 & 3914.3 & 8100.7 & 295.1 & 95.68 & 46.21 & 96.60 \\
\hline 9 & 17409.3 & 6267.8 & 4505.8 & 8253.9 & 305.8 & 97.78 & 53.19 & 98.43 \\
\hline 11 & 17714.3 & 6386.2 & 5295.7 & 8381.2 & 403.6 & 99.62 & 62.51 & 99.95 \\
\hline 13 & 18326.0 & 6410.3 & 5935.7 & 8385.5 & 455.5 & 100.00 & 70.07 & 100.00 \\
\hline 15 & 18621.5 & 6251.4 & 6473.0 & 8145.9 & 480.9 & 97.52 & 76.41 & 97.14 \\
\hline 17 & 18864.9 & 6105.1 & 6901.0 & 7924.3 & 507.5 & 95.24 & 81.46 & 94.50 \\
\hline 19 & 19073.8 & 5889.6 & 7268.1 & 7616.9 & 535.5 & 91.88 & 85.80 & 90.83 \\
\hline 21 & 19275.3 & 5422.9 & 7607.3 & 6975.4 & 546.5 & 84.60 & 89.80 & 83.18 \\
\hline 23 & 19478.7 & 5116.8 & 7962.2 & 6559.9 & 565.3 & 79.82 & 93.99 & 78.23 \\
\hline 25 & 19670.8 & 4672.1 & 8191.9 & 5971.2 & 573.0 & 72.89 & 96.70 & 71.21 \\
\hline 27 & 19855.6 & 4209.9 & 8412.6 & 5376.5 & 575.5 & 65.67 & 99.31 & 64.12 \\
\hline 29 & 20024.8 & 3740.6 & 8471.3 & 4781.7 & 573.0 & 58.35 & 100.00 & 57.02 \\
\hline 31 & 20194.2 & 3355.4 & 8393.7 & 4292.6 & 566.7 & 52.34 & 99.08 & 51.19 \\
\hline 33 & 20339.9 & 2766.9 & 8246.6 & 3542.3 & 552.6 & 43.16 & 97.35 & 42.24 \\
\hline 35 & 20465.5 & 2303.9 & 8050.2 & 2933.2 & 521.9 & 35.94 & 95.03 & 34.98 \\
\hline 37 & 20583.8 & 1979.8 & 7793.0 & 2504.3 & 476.3 & 30.88 & 91.99 & 29.86 \\
\hline 39.4 & 20716.7 & 1682.6 & 7320.8 & 2112.5 & 452.2 & 26.25 & 86.42 & 25.19 \\
\hline
\end{tabular}

\section{CHINOOK SALMON}

\begin{tabular}{|c|c|c|c|c|c|c|c|c|}
\hline \multirow{2}{*}{$\begin{array}{c}\text { Discharge } \\
\left(\mathrm{ft}^{3} / \mathrm{s}\right)\end{array}$} & \multirow{2}{*}{$\begin{array}{c}\text { Total Area } \\
\quad\left(\mathrm{ft}^{2}\right)\end{array}$} & \multicolumn{4}{|c|}{ Summary of Weighted Usable Area $\left(\mathrm{ft}^{2} / 1000 \mathrm{ft}\right)$} & \multicolumn{3}{|c|}{ Percent of Optimum } \\
\hline & & Adult & Spawning & Juvenile & Cover & Adult & Spawning & Juvenile \\
\hline 3 & 15030.6 & 5333.0 & 1797.4 & 5996.3 & 268.4 & 49.63 & 13.81 & 84.39 \\
\hline 5 & 16259.8 & 6477.8 & 4101.4 & 6662.5 & 300.5 & 60.28 & 31.52 & 93.76 \\
\hline 7.7 & 17150.8 & 7410.0 & 5779.0 & 7065.0 & 359.6 & 68.96 & 44.42 & 99.43 \\
\hline 9 & 17409.3 & 7679.2 & 6542.7 & 7105.5 & 374.0 & 71.46 & 50.29 & 100.00 \\
\hline 11 & 17714.3 & 8225.9 & 7553.4 & 7066.5 & 391.5 & 76.55 & 58.05 & 99.45 \\
\hline 13 & 18326.0 & 8701.7 & 8280.4 & 7022.7 & 407.0 & 80.98 & 63.64 & 98.83 \\
\hline 15 & 18621.5 & 9170.6 & 8963.5 & 6819.4 & 418.4 & 85.34 & 68.89 & 95.97 \\
\hline 17 & 18864.9 & 9483.4 & 9477.6 & 6571.6 & 427.7 & 88.25 & 72.84 & 92.49 \\
\hline 19 & 19073.8 & 9744.0 & 9988.0 & 6276.1 & 435.1 & 90.67 & 76.77 & 88.33 \\
\hline 21 & 19275.3 & 9975.7 & 10505.0 & 5951.5 & 439.6 & 92.83 & 80.74 & 83.76 \\
\hline 23 & 19478.7 & 10235.2 & 11025.7 & 5626.2 & 441.7 & 95.25 & 84.74 & 79.18 \\
\hline 25 & 19670.8 & 10385.0 & 11457.0 & 5121.8 & 442.2 & 96.64 & 88.06 & 72.08 \\
\hline 27 & 19855.6 & 10541.0 & 11921.4 & 4762.7 & 441.1 & 98.09 & 91.62 & 67.03 \\
\hline 29 & 20024.8 & 10620.5 & 12259.4 & 4278.2 & 437.4 & 98.83 & 94.22 & 60.21 \\
\hline 31 & 20194.2 & 10715.8 & 12504.6 & 3892.7 & 434.4 & 99.72 & 96.11 & 54.78 \\
\hline 33 & 20339.9 & 10746.1 & 12680.3 & 3515.4 & 429.7 & 100.00 & 97.46 & 49.47 \\
\hline 35 & 20465.5 & 10738.0 & 12824.6 & 3201.7 & 419.4 & 99.92 & 98.57 & 45.06 \\
\hline 37 & 20583.8 & 10729.0 & 12937.8 & 2878.3 & 418.5 & 99.84 & 99.44 & 40.51 \\
\hline 39.4 & 20716.7 & 10646.9 & 13011.1 & 2469.6 & 398.0 & 99.08 & 100.00 & 34.76 \\
\hline
\end{tabular}


Table 12A. Weighted usable area for bull trout, chinook salmon, steelhead trout life stages, and cover for juvenile life stages, site VC3, upper Valley Creek, 2003-Continued

\section{STEELHEAD}

\begin{tabular}{|c|c|c|c|c|c|c|c|c|}
\hline \multirow{2}{*}{$\begin{array}{c}\text { Discharge } \\
\qquad\left(\mathrm{ft}^{3} / \mathrm{s}\right)\end{array}$} & \multirow{2}{*}{$\begin{array}{c}\text { Total Area } \\
\quad\left(\mathrm{ft}^{2}\right)\end{array}$} & \multicolumn{4}{|c|}{ Summary of Weighted Usable Area $\left(\mathrm{ft}^{2} / 1000 \mathrm{ft}\right)$} & \multicolumn{3}{|c|}{ Percent of Optimum } \\
\hline & & Adult & Spawning & Juvenile & Cover & Adult & Spawning & Juvenile \\
\hline 3 & 15030.6 & 5333.0 & 1797.4 & 8931.0 & 296.0 & 49.63 & 13.81 & 69.86 \\
\hline 5 & 16259.8 & 6477.8 & 4101.4 & 10491.5 & 493.0 & 60.28 & 31.52 & 82.07 \\
\hline 7.7 & 17150.8 & 7410.0 & 5779.0 & 11710.3 & 466.1 & 68.96 & 44.42 & 91.61 \\
\hline 9 & 17409.3 & 7679.2 & 6542.7 & 12084.5 & 488.7 & 71.46 & 50.29 & 94.53 \\
\hline 11 & 17714.3 & 8225.9 & 7553.4 & 12401.5 & 516.2 & 76.55 & 58.05 & 97.01 \\
\hline 13 & 18326.0 & 8701.7 & 8280.4 & 12757.3 & 549.5 & 80.98 & 63.64 & 99.80 \\
\hline 15 & 18621.5 & 9170.6 & 8963.5 & 12783.5 & 578.6 & 85.34 & 68.89 & 100.00 \\
\hline 17 & 18864.9 & 9483.4 & 9477.6 & 12413.0 & 604.9 & 88.25 & 72.84 & 97.10 \\
\hline 19 & 19073.8 & 9744.0 & 9988.0 & 11611.9 & 627.4 & 90.67 & 76.77 & 90.84 \\
\hline 21 & 19275.3 & 9975.7 & 10505.0 & 10833.6 & 650.9 & 92.83 & 80.74 & 84.75 \\
\hline 23 & 19478.7 & 10235.2 & 11025.7 & 9854.3 & 665.0 & 95.25 & 84.74 & 77.09 \\
\hline 25 & 19670.8 & 10385.0 & 11457.0 & 8837.4 & 674.9 & 96.64 & 88.06 & 69.13 \\
\hline 27 & 19855.6 & 10541.0 & 11921.4 & 7949.9 & 676.9 & 98.09 & 91.62 & 62.19 \\
\hline 29 & 20024.8 & 10620.5 & 12259.4 & 7372.1 & 673.3 & 98.83 & 94.22 & 57.67 \\
\hline 31 & 20194.2 & 10715.8 & 12504.6 & 6749.4 & 655.7 & 99.72 & 96.11 & 52.80 \\
\hline 33 & 20339.9 & 10746.1 & 12680.3 & 5756.2 & 637.5 & 100.00 & 97.46 & 45.03 \\
\hline 35 & 20465.5 & 10738.0 & 12824.6 & 5257.0 & 597.1 & 99.92 & 98.57 & 41.12 \\
\hline 37 & 20583.8 & 10729.0 & 12937.8 & 4584.9 & 573.3 & 99.84 & 99.44 & 35.87 \\
\hline 39.4 & 20716.7 & 10646.9 & 13011.1 & 4075.4 & 570.4 & 99.08 & 100.00 & 31.88 \\
\hline
\end{tabular}


Figure 55A

Percent of Contiguous Stream Width

Upper Valley Creek - VC3

Passage Transect 2 (wide moderate slope)

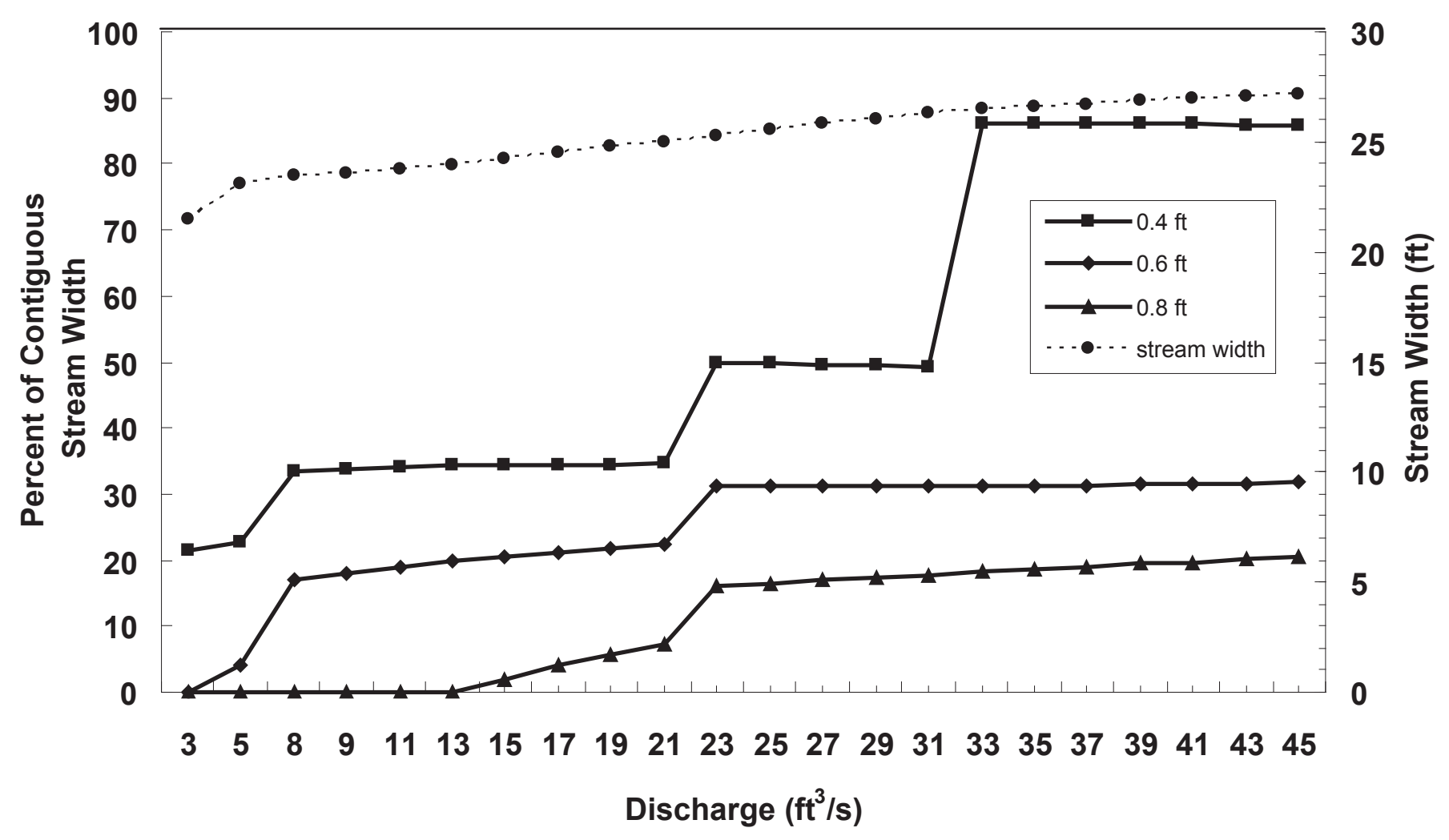

Discharge $\left(\mathrm{ft}^{3} / \mathrm{s}\right)$ 
Figure 56A

Percent of Total Stream Width

Upper Valley Creek - VC3

Passage Transect 2 (wide moderate slope)

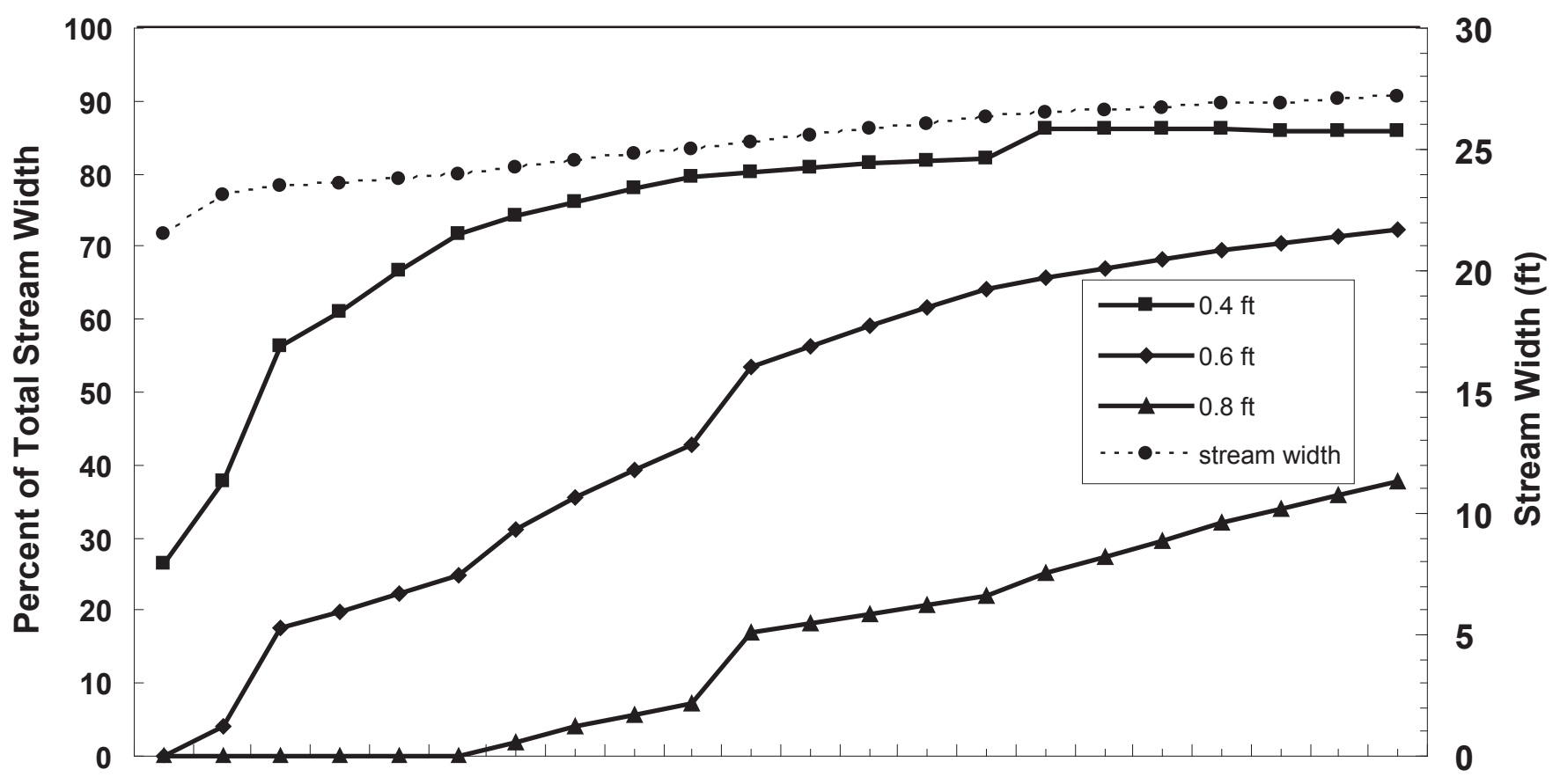

$\begin{array}{llllllllllllllllllllll}3 & 5 & 8 & 9 & 11 & 13 & 15 & 17 & 19 & 21 & 23 & 25 & 27 & 29 & 31 & 33 & 35 & 37 & 39 & 41 & 43 & 45\end{array}$

Discharge $\left(\mathrm{ft}^{3} / \mathrm{s}\right)$ 
Table 13A. Passage criteria assessment for transect 2 (wide moderate slope), site VC3, upper Valley Creek, 2003

\begin{tabular}{|c|c|c|c|c|c|}
\hline $\begin{array}{c}\text { Discharge } \\
\left(\mathrm{ft}^{3} / \mathrm{s}\right)\end{array}$ & $\begin{array}{c}\text { Stream width } \\
\text { (ft) }\end{array}$ & $\begin{array}{c}\text { Total Stream } \\
\text { Width Greater } \\
\text { Than } 0.4 \mathrm{ft} \text { depth }\end{array}$ & $\begin{array}{l}\text { Percent Stream } \\
\text { Width Greater } \\
\text { Than } 0.4 \mathrm{ft} \text { Depth }\end{array}$ & $\begin{array}{l}\text { Contiguous Stream } \\
\text { Width Greater Than } \\
0.4 \mathrm{ft} \text { Depth }\end{array}$ & $\begin{array}{l}\text { Percent Contiguous } \\
\text { Stream Width Greater } \\
\text { Than } 0.4 \mathrm{ft} \text { Depth }\end{array}$ \\
\hline 3 & 21.50 & 5.66 & 26.31 & 4.63 & 21.52 \\
\hline 5 & 23.10 & 8.69 & 37.63 & 5.22 & 22.60 \\
\hline 7.7 & 23.45 & 13.23 & 56.43 & 7.87 & 33.57 \\
\hline 9 & 23.59 & 14.36 & 60.87 & 7.98 & 33.80 \\
\hline 11 & 23.79 & 15.85 & 66.63 & 8.11 & 34.10 \\
\hline 13 & 23.96 & 17.20 & 71.80 & 8.24 & 34.37 \\
\hline 15 & 24.25 & 17.97 & 74.13 & 8.35 & 34.43 \\
\hline 17 & 24.53 & 18.68 & 76.15 & 8.46 & 34.48 \\
\hline 19 & 24.78 & 19.30 & 77.90 & 8.55 & 34.51 \\
\hline 21 & 25.02 & 19.90 & 79.55 & 8.64 & 34.55 \\
\hline 23 & 25.30 & 20.31 & 80.30 & 12.63 & 49.94 \\
\hline 25 & 25.56 & 20.65 & 80.80 & 12.72 & 49.76 \\
\hline 27 & 25.83 & 20.99 & 81.29 & 12.80 & 49.57 \\
\hline 29 & 26.06 & 21.30 & 81.72 & 12.88 & 49.41 \\
\hline 31 & 26.31 & 21.62 & 82.17 & 12.96 & 49.24 \\
\hline 33 & 26.49 & 22.83 & 86.18 & 22.83 & 86.18 \\
\hline 35 & 26.61 & 22.92 & 86.13 & 22.92 & 86.13 \\
\hline 37 & 26.72 & 23.00 & 86.08 & 23.00 & 86.08 \\
\hline 39.4 & 26.84 & 23.09 & 86.03 & 23.09 & 86.03 \\
\hline 41 & 26.93 & 23.16 & 85.99 & 23.16 & 85.99 \\
\hline 43 & 27.03 & 23.23 & 85.95 & 23.23 & 85.95 \\
\hline 45 & 27.13 & 23.31 & 85.91 & 23.31 & 85.91 \\
\hline $\begin{array}{c}\text { Discharge } \\
\left(\mathrm{ft}^{3} / \mathrm{s}\right)\end{array}$ & $\begin{array}{c}\text { Stream width } \\
(\mathrm{ft})\end{array}$ & $\begin{array}{c}\text { Total Stream } \\
\text { Width Greater } \\
\text { Than } 0.6 \text { ft depth }\end{array}$ & $\begin{array}{l}\text { Percent Stream } \\
\text { Width Greater } \\
\text { Than } 0.6 \text { ft Depth }\end{array}$ & $\begin{array}{l}\text { Contiguous Stream } \\
\text { Width Greater Than } \\
0.6 \mathrm{ft} \text { Depth }\end{array}$ & $\begin{array}{l}\text { Percent Contiguous } \\
\text { Stream Width Greater } \\
\text { Than } 0.6 \mathrm{ft} \text { Depth }\end{array}$ \\
\hline 3 & 21.50 & 0.00 & 0.00 & 0.00 & 0.00 \\
\hline 5 & 23.10 & 0.97 & 4.19 & 0.97 & 4.19 \\
\hline 7.7 & 23.45 & 4.11 & 17.54 & 3.99 & 17.01 \\
\hline 9 & 23.59 & 4.64 & 19.67 & 4.21 & 17.83 \\
\hline 11 & 23.79 & 5.34 & 22.44 & 4.50 & 18.90 \\
\hline 13 & 23.96 & 5.97 & 24.92 & 4.76 & 19.85 \\
\hline 15 & 24.25 & 7.53 & 31.06 & 4.99 & 20.60 \\
\hline 17 & 24.53 & 8.69 & 35.44 & 5.22 & 21.29 \\
\hline 19 & 24.78 & 9.72 & 39.22 & 5.42 & 21.88 \\
\hline 21 & 25.02 & 10.70 & 42.77 & 5.62 & 22.44 \\
\hline 23 & 25.30 & 13.55 & 53.55 & 7.90 & 31.23 \\
\hline 25 & 25.56 & 14.41 & 56.36 & 7.98 & 31.22 \\
\hline 27 & 25.83 & 15.26 & 59.10 & 8.06 & 31.20 \\
\hline 29 & 26.06 & 16.03 & 61.51 & 8.13 & 31.19 \\
\hline 31 & 26.31 & 16.84 & 64.02 & 8.20 & 31.18 \\
\hline 33 & 26.49 & 17.43 & 65.80 & 8.27 & 31.20 \\
\hline 35 & 26.61 & 17.84 & 67.04 & 8.33 & 31.30 \\
\hline 37 & 26.72 & 18.22 & 68.19 & 8.39 & 31.39 \\
\hline 39.4 & 26.84 & 18.65 & 69.49 & 8.45 & 31.49 \\
\hline 41 & 26.93 & 18.95 & 70.37 & 8.50 & 31.56 \\
\hline 43 & 27.03 & 19.30 & 71.41 & 8.55 & 31.64 \\
\hline 45 & 27.13 & 19.63 & 72.36 & 8.60 & 31.71 \\
\hline
\end{tabular}


Table 13A. Passage criteria assessment for transect 2 (wide moderate slope), site VC3, upper Valley Creek, 2003—Continued

\begin{tabular}{|c|c|c|c|c|c|}
\hline $\begin{array}{c}\text { Discharge } \\
\left(\mathrm{ft}^{3} / \mathrm{s}\right)\end{array}$ & $\begin{array}{c}\text { Stream width } \\
\text { (ft) }\end{array}$ & $\begin{array}{c}\text { Total Stream } \\
\text { Width Greater } \\
\text { Than } 0.8 \mathrm{ft} \text { depth }\end{array}$ & $\begin{array}{l}\text { Percent Stream } \\
\text { Width Greater } \\
\text { Than } 0.8 \text { ft Depth }\end{array}$ & $\begin{array}{c}\text { Contiguous Stream } \\
\text { Width Greater Than } \\
0.8 \mathrm{ft} \text { Depth }\end{array}$ & $\begin{array}{l}\text { Percent Contiguous } \\
\text { Stream Width Greater } \\
\text { Than } \mathbf{0 . 8} \mathrm{ft} \text { Depth }\end{array}$ \\
\hline 3 & 21.50 & 0.00 & 0.00 & 0.00 & 0.00 \\
\hline 5 & 23.10 & 0.00 & 0.00 & 0.00 & 0.00 \\
\hline 7.7 & 23.45 & 0.00 & 0.00 & 0.00 & 0.00 \\
\hline 9 & 23.59 & 0.00 & 0.00 & 0.00 & 0.00 \\
\hline 11 & 23.79 & 0.00 & 0.00 & 0.00 & 0.00 \\
\hline 13 & 23.96 & 0.00 & 0.00 & 0.00 & 0.00 \\
\hline 15 & 24.25 & 0.47 & 1.96 & 0.47 & 1.96 \\
\hline 17 & 24.53 & 0.97 & 3.95 & 0.97 & 3.95 \\
\hline 19 & 24.78 & 1.41 & 5.67 & 1.41 & 5.67 \\
\hline 21 & 25.02 & 1.82 & 7.29 & 1.82 & 7.29 \\
\hline 23 & 25.30 & 4.26 & 16.84 & 4.05 & 16.00 \\
\hline 25 & 25.56 & 4.66 & 18.24 & 4.21 & 16.49 \\
\hline 27 & 25.83 & 5.06 & 19.61 & 4.38 & 16.96 \\
\hline 29 & 26.06 & 5.42 & 20.81 & 4.53 & 17.38 \\
\hline 31 & 26.31 & 5.80 & 22.06 & 4.69 & 17.82 \\
\hline 33 & 26.49 & 6.64 & 25.06 & 4.82 & 18.19 \\
\hline 35 & 26.61 & 7.31 & 27.47 & 4.95 & 18.60 \\
\hline 37 & 26.72 & 7.93 & 29.69 & 5.07 & 18.99 \\
\hline 39.4 & 26.84 & 8.65 & 32.21 & 5.21 & 19.42 \\
\hline 41 & 26.93 & 9.14 & 33.93 & 5.31 & 19.71 \\
\hline 43 & 27.03 & 9.72 & 35.95 & 5.42 & 20.06 \\
\hline 45 & 27.13 & 10.25 & 37.80 & 5.53 & 20.38 \\
\hline
\end{tabular}




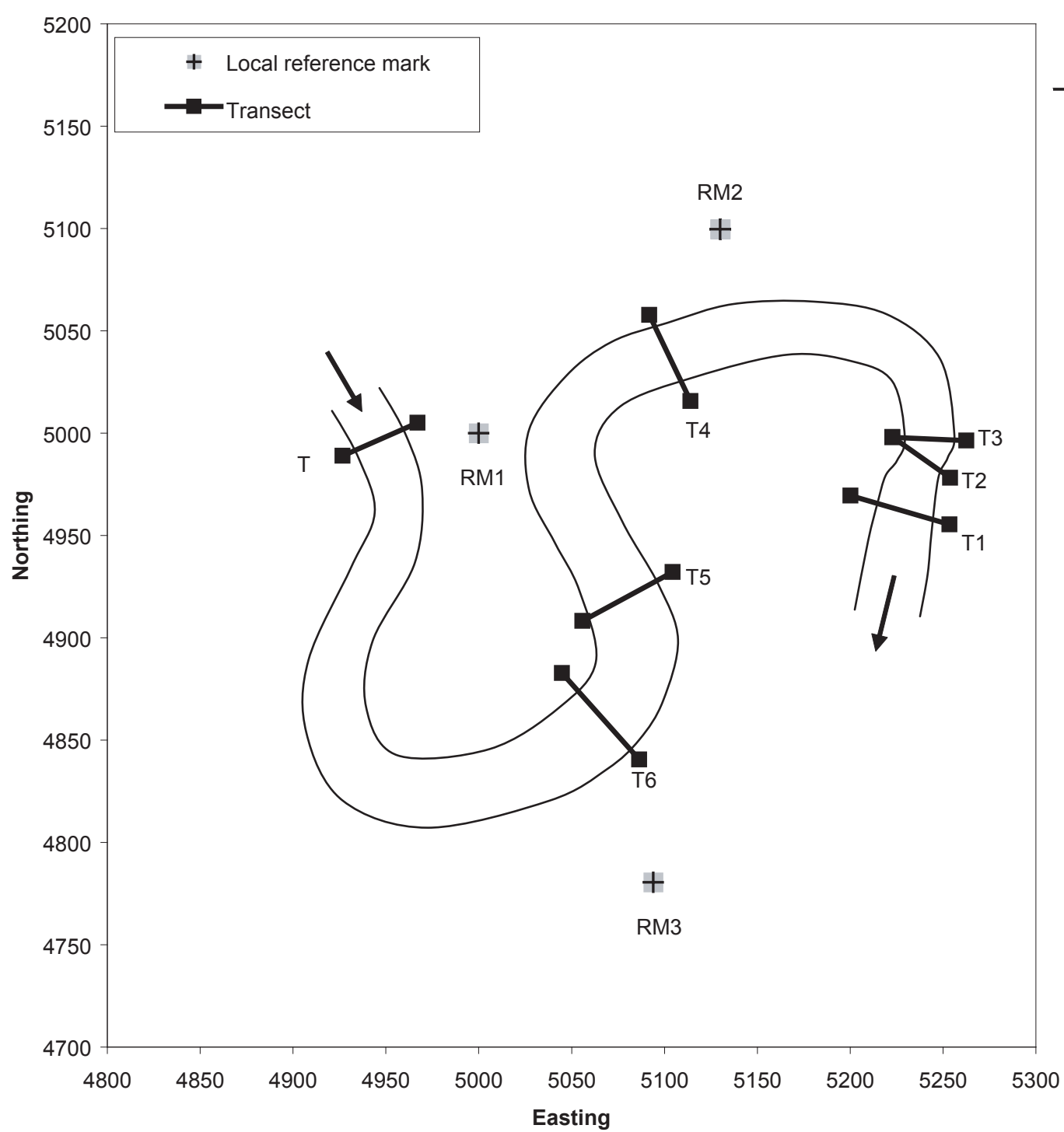

Transect Endpoint Coordinates (NAD 83)

\begin{tabular}{ccc} 
Point & Latitude & Longitude \\
\hline LB T1 & $115^{\circ} 11^{\prime} 30.76^{\prime \prime} \mathrm{W}$ & $44^{\circ} 17^{\prime} 38.86^{\prime \prime} \mathrm{N}$
\end{tabular}

RB T1 $115^{\circ} 11^{\prime} 30.01 " \mathrm{~W} \quad 44^{\circ} 17^{\prime} 38.77^{\prime \prime} \mathrm{N}$

LB T2 $115^{\circ} 11^{\prime} 30.49^{\prime \prime} \mathrm{W} \quad 44^{\circ} 17^{\prime} 39.16^{\prime \prime} \mathrm{N}$

RB T2 $115^{\circ} 11^{\prime} 30.04^{\prime \prime} \mathrm{W} \quad 44^{\circ} 17^{\prime} 39.00^{\prime \prime} \mathrm{N}$

LB T3 $115^{\circ} 11^{\prime} 30.49^{\prime \prime} \mathrm{W} \quad 44^{\circ} 17^{\prime} 39.16^{\prime \prime} \mathrm{N}$

RB T3 $115^{\circ} 11^{\prime} 29.95^{\prime \prime} \mathrm{W} \quad 44^{\circ} 17^{\prime} 39.18^{\prime \prime} \mathrm{N}$

LB T4 $115^{\circ} 11^{\prime} 32.01^{\prime \prime} \mathrm{W} \quad 44^{\circ} 17^{\prime} 39.22^{\prime \prime} \mathrm{N}$

RB T4 $115^{\circ} 11^{\prime} 32.37^{\prime \prime} \mathrm{W} \quad 44^{\circ} 17^{\prime} 39.61^{\prime \prime} \mathrm{N}$

LB T5 $115^{\circ} 11^{\prime} 32.01^{\prime \prime} \mathrm{W} \quad 44^{\circ} 17^{\prime} 38.39^{\prime \prime} \mathrm{N}$

RB T5 $115^{\circ} 11^{\prime} 32.64^{\prime \prime} \mathrm{W} \quad 44^{\circ} 17^{\prime} 38.11^{\prime \prime} \mathrm{N}$

LB T6 $115^{\circ} 11^{\prime} 32.13^{\prime \prime} \mathrm{W} \quad 44^{\circ} 17^{\prime} 37.47^{\prime \prime} \mathrm{N}$

RB T6 $115^{\circ} 11^{\prime} 32.76^{\prime \prime} \mathrm{W} \quad 44^{\circ} 17^{\prime} 37.85^{\prime \prime} \mathrm{N}$

LB T7 $115^{\circ} 11^{\prime} 34.52^{\prime \prime} \mathrm{W} \quad 44^{\circ} 17^{\prime} 38.76^{\prime \prime} \mathrm{N}$

RB T7 $115^{\circ} 11^{\prime} 34.00^{\prime \prime} \mathrm{W} \quad 44^{\circ} 17^{\prime} 38.97^{\prime \prime} \mathrm{N}$

For reference only; stream schematic not to scale.

Figure 57A

Middle Valley Creek - VC2

Plan View 
Figure 58A

Middle Valley Creek - VC2

Bull Trout WUA

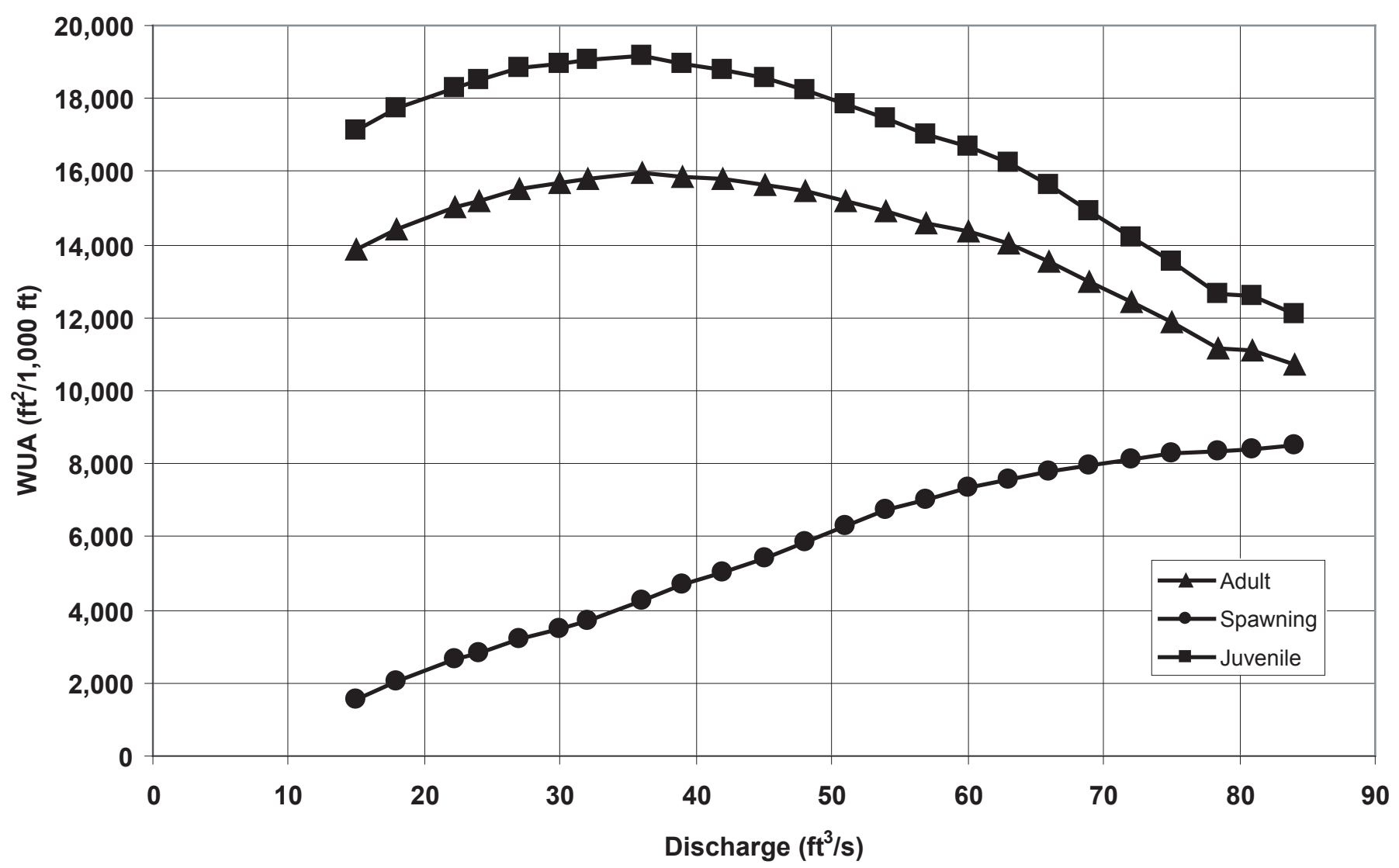


Figure 59A

Middle Valley Creek - VC2

Bull Trout WUA Normalized

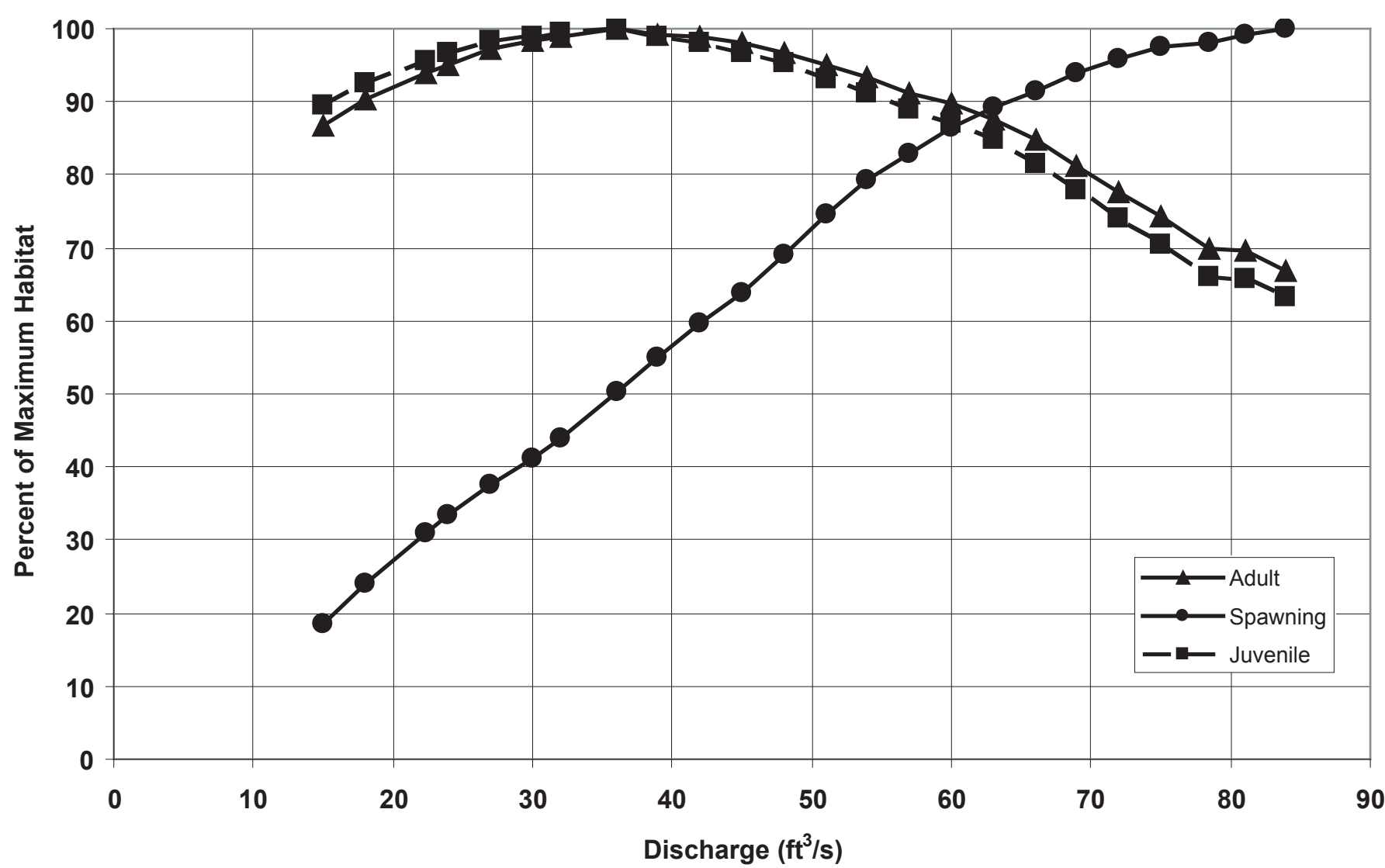


Figure 60A

Middle Valley Creek - VC2

Chinook Salmon WUA

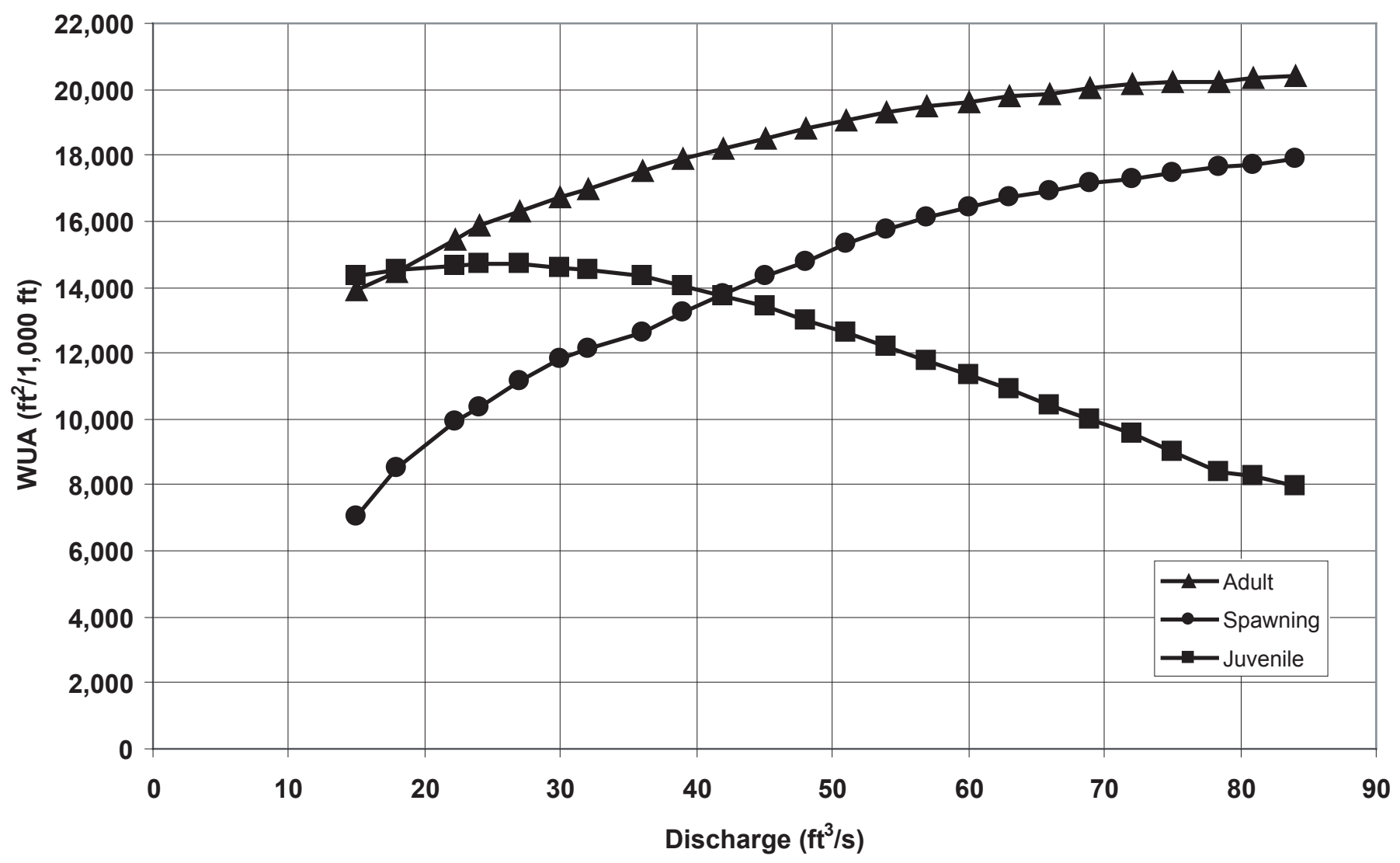


Figure 61A

Middle Valley Creek - VC2

Chinook Salmon WUA Normalizec

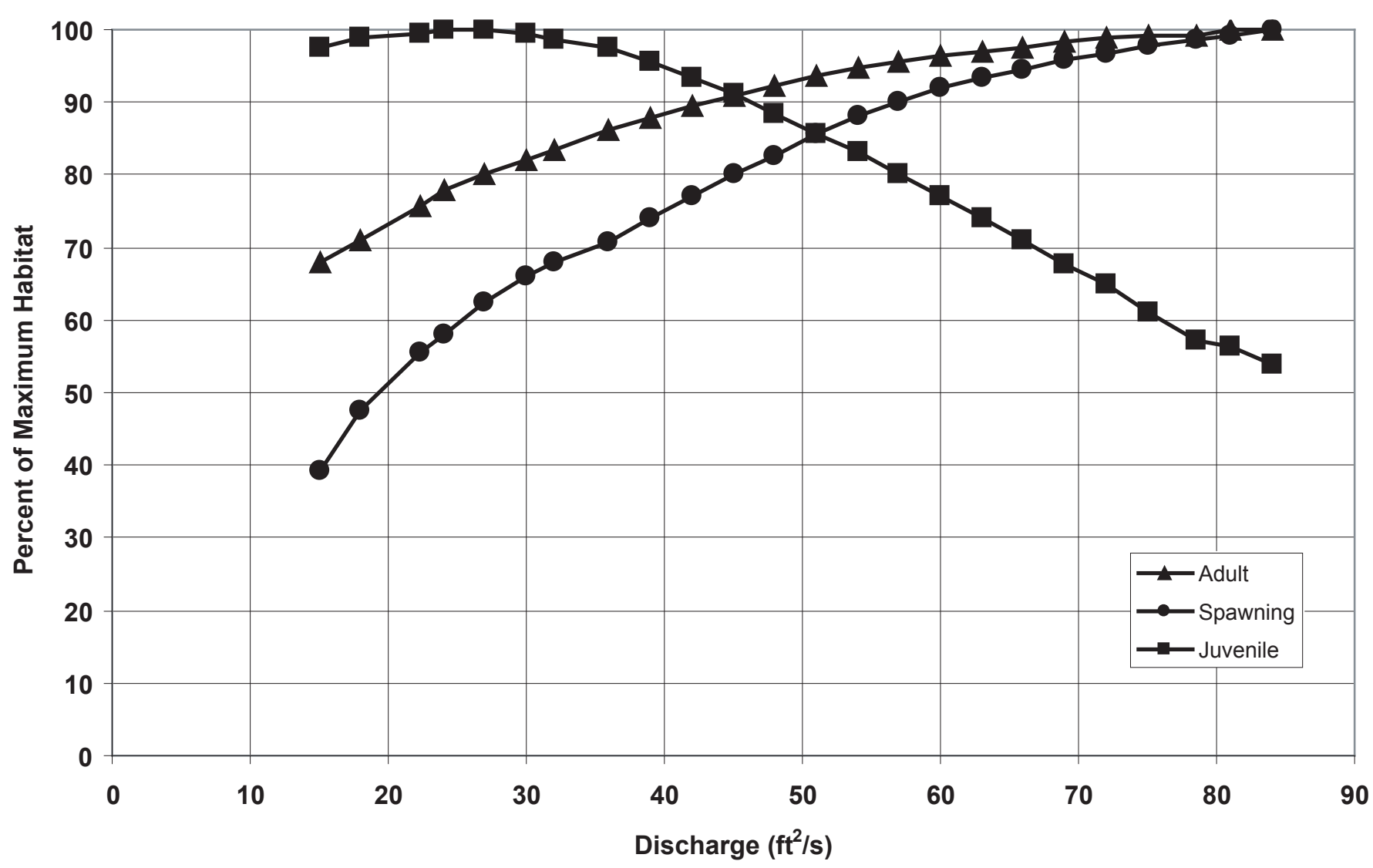

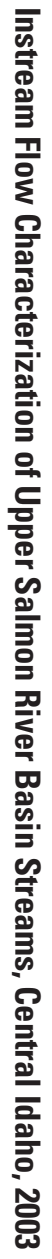


Figure 62A

Middle Valley Creek - VC2

Steelhead WUA

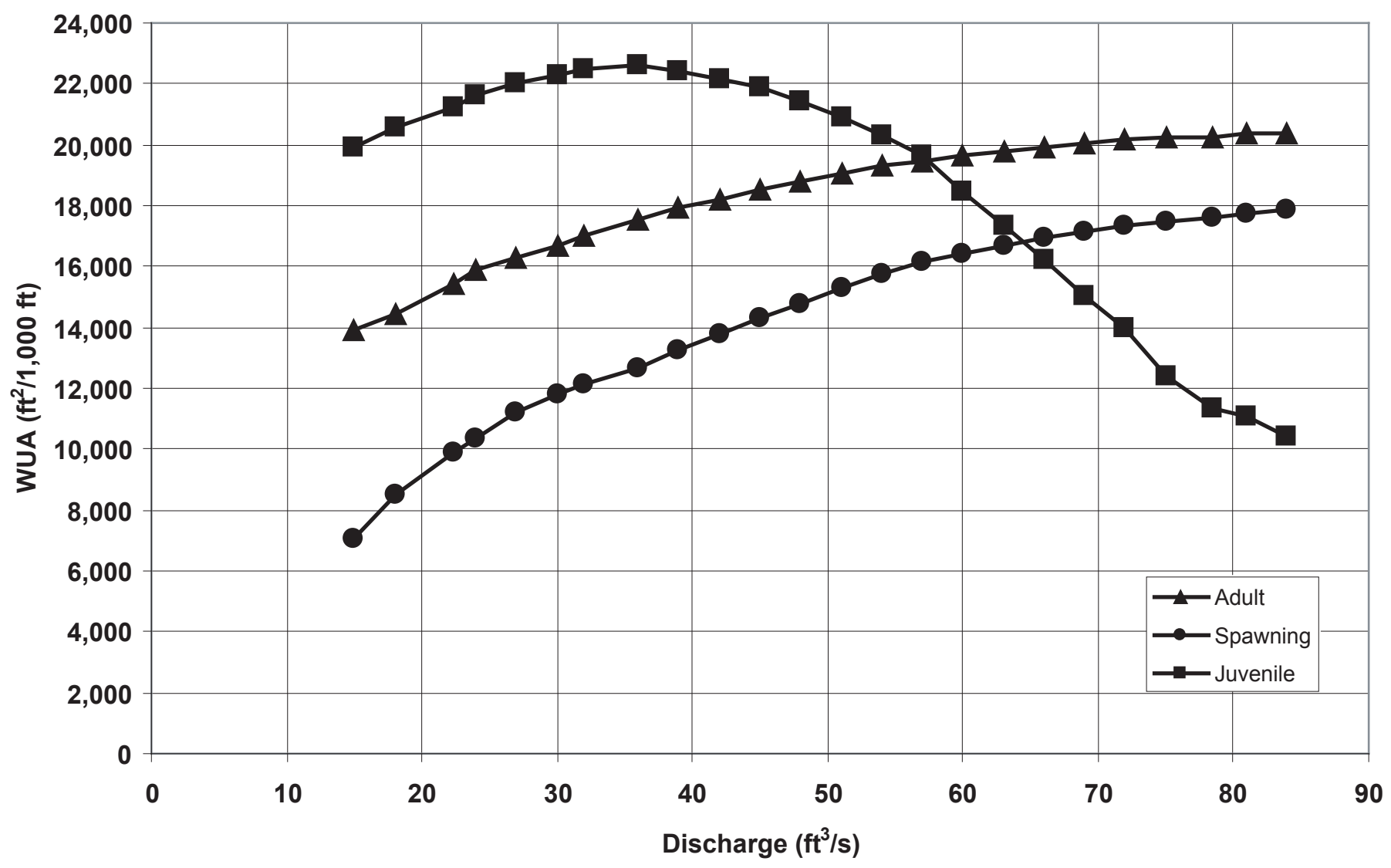


Figure 63A

Middle Valley Creek - VC2

Steelhead WUA Normalized

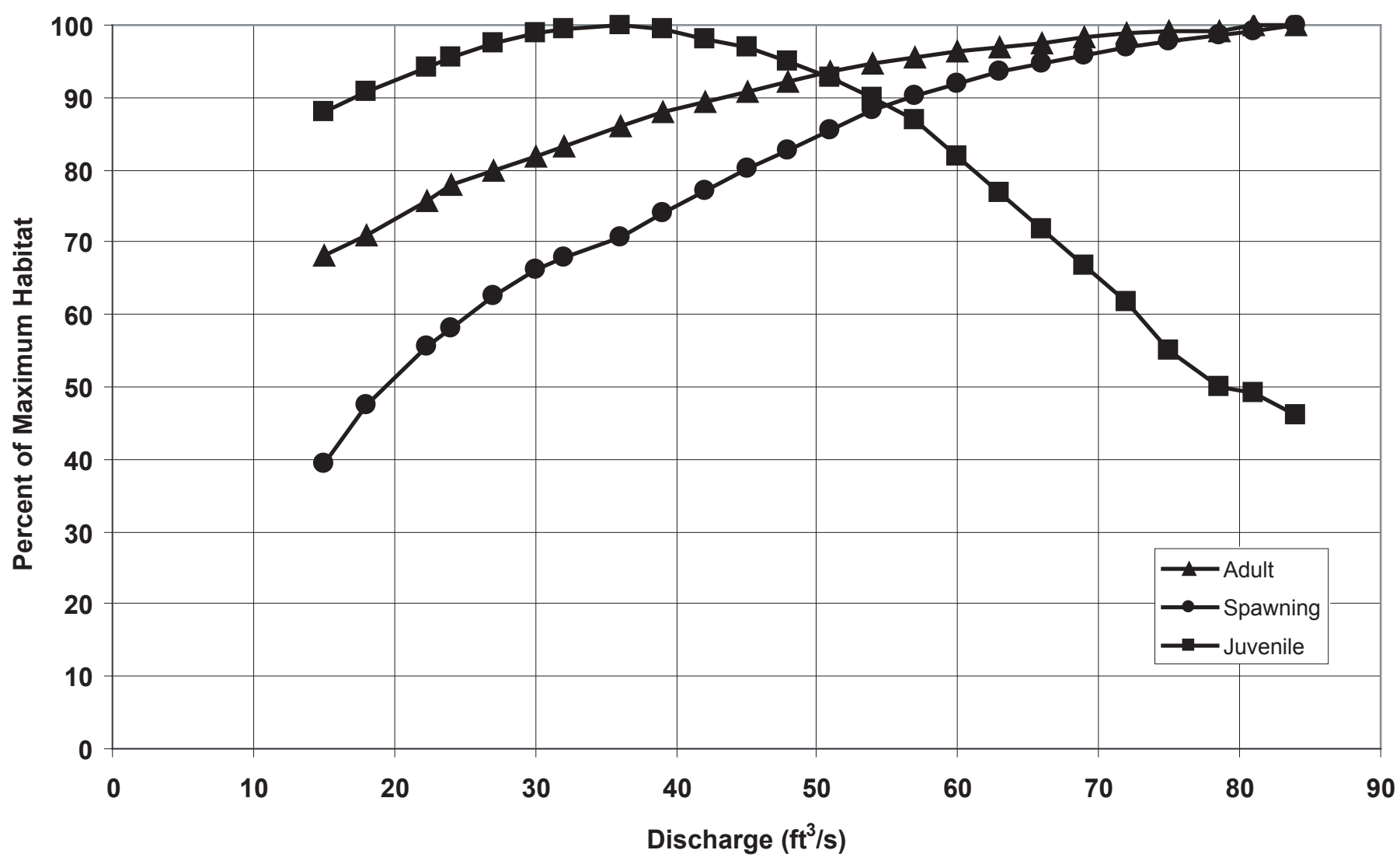


Table 14A. Weighted usable area for bull trout, chinook salmon, steelhead trout life stages, and cover for juvenile life stages, site VC2, middle Valley Creek, 2003

\section{BULL TROUT}

\begin{tabular}{|c|c|c|c|c|c|c|c|c|}
\hline \multirow{2}{*}{$\begin{array}{c}\text { Discharge } \\
\left(\mathrm{ft}^{3} / \mathrm{s}\right)\end{array}$} & \multirow{2}{*}{$\begin{array}{c}\text { Total Area } \\
\left(\mathrm{ft}^{2}\right)\end{array}$} & \multicolumn{4}{|c|}{ Summary of Weighted Usable Area ( $\left.\mathrm{ft}^{2} / 1000 \mathrm{ft}\right)$} & \multicolumn{3}{|c|}{ Percent of Optimum } \\
\hline & & Adult & Spawning & Juvenile & Cover & Adult & Spawning & Juvenile \\
\hline 15 & 26003.4 & 13871.7 & 1563.9 & 17131.6 & 272.3 & 86.76 & 18.43 & 89.39 \\
\hline 18 & 26550.5 & 14440.4 & 2033.4 & 17739.2 & 290.6 & 90.32 & 23.96 & 92.56 \\
\hline 22.3 & 27328.5 & 15005.1 & 2624.7 & 18312.9 & 315.8 & 93.85 & 30.93 & 95.56 \\
\hline 24 & 27681.3 & 15200.6 & 2843.1 & 18504.0 & 325.7 & 95.07 & 33.50 & 96.55 \\
\hline 27 & 28119.3 & 15531.2 & 3177.4 & 18846.1 & 338.3 & 97.14 & 37.44 & 98.34 \\
\hline 30 & 28430.8 & 15702.5 & 3490.8 & 18970.6 & 348.7 & 98.21 & 41.13 & 98.99 \\
\hline 32 & 28585.7 & 15809.4 & 3724.9 & 19054.3 & 355.0 & 98.88 & 43.89 & 99.43 \\
\hline 36 & 29163.7 & 15988.3 & 4275.2 & 19164.3 & 369.1 & 100.00 & 50.37 & 100.00 \\
\hline 39 & 29267.4 & 15877.9 & 4676.4 & 18947.2 & 376.3 & 99.31 & 55.10 & 98.87 \\
\hline 42 & 29369.1 & 15790.7 & 5052.6 & 18767.3 & 383.1 & 98.76 & 59.53 & 97.93 \\
\hline 45 & 29463.8 & 15658.2 & 5410.2 & 18536.7 & 389.3 & 97.93 & 63.75 & 96.73 \\
\hline 48 & 29553.1 & 15465.9 & 5857.8 & 18240.1 & 395.0 & 96.73 & 69.02 & 95.18 \\
\hline 51 & 29639.6 & 15191.9 & 6321.4 & 17852.5 & 400.5 & 95.02 & 74.48 & 93.15 \\
\hline 54 & 29740.2 & 14930.0 & 6717.1 & 17481.2 & 405.7 & 93.38 & 79.14 & 91.22 \\
\hline 57 & 29845.4 & 14590.1 & 7027.4 & 17020.6 & 410.7 & 91.25 & 82.80 & 88.81 \\
\hline 60 & 29942.9 & 14350.4 & 7337.2 & 16687.0 & 415.4 & 89.76 & 86.45 & 87.07 \\
\hline 63 & 30054.3 & 14020.9 & 7568.9 & 16248.1 & 420.0 & 87.69 & 89.18 & 84.78 \\
\hline 66 & 30167.3 & 13539.7 & 7766.5 & 15627.2 & 424.3 & 84.69 & 91.51 & 81.54 \\
\hline 69 & 30275.8 & 12996.8 & 7959.9 & 14935.3 & 428.5 & 81.29 & 93.79 & 77.93 \\
\hline 72 & 30383.6 & 12425.2 & 8145.6 & 14213.8 & 432.5 & 77.71 & 95.98 & 74.17 \\
\hline 75 & 30510.7 & 11862.5 & 8267.2 & 13522.3 & 436.2 & 74.19 & 97.41 & 70.56 \\
\hline 78.5 & 30621.5 & 11153.4 & 8327.0 & 12660.0 & 439.4 & 69.76 & 98.11 & 66.06 \\
\hline 81 & 30782.6 & 11119.1 & 8421.5 & 12617.1 & 441.0 & 69.55 & 99.23 & 65.84 \\
\hline 84 & 30930.1 & 10694.6 & 8487.1 & 12112.2 & 442.0 & 66.89 & 100.00 & 63.20 \\
\hline
\end{tabular}


Table 14A. Weighted usable area for bull trout, chinook salmon, steelhead trout life stages, and cover for juvenile life stages, site VC2, middle Valley Creek, 2003-Continued

\section{CHINOOK SALMON}

\begin{tabular}{|c|c|c|c|c|c|c|c|c|}
\hline \multirow{2}{*}{$\begin{array}{c}\text { Discharge } \\
\left(\mathrm{ft}^{3} / \mathrm{s}\right)\end{array}$} & \multirow{2}{*}{$\begin{array}{c}\text { Total Area } \\
\left(\mathrm{ft}^{2}\right)\end{array}$} & \multicolumn{4}{|c|}{ Summary of Weighted Usable Area ( $\left.\mathrm{ft}^{2} / 1000 \mathrm{ft}\right)$} & \multicolumn{3}{|c|}{ Percent of Optimum } \\
\hline & & Adult & Spawning & Juvenile & Cover & Adult & Spawning & Juvenile \\
\hline 15 & 26003.4 & 13883.2 & 7025.5 & 14329.6 & 193.6 & 68.09 & 39.29 & 97.47 \\
\hline 18 & 26550.5 & 14454.6 & 8491.0 & 14548.5 & 206.9 & 70.89 & 47.49 & 98.96 \\
\hline 22.3 & 27328.5 & 15440.5 & 9921.3 & 14635.3 & 225.1 & 75.73 & 55.49 & 99.55 \\
\hline 24 & 27681.3 & 15877.4 & 10366.3 & 14701.9 & 232.1 & 77.87 & 57.98 & 100.00 \\
\hline 27 & 28119.3 & 16316.5 & 11180.5 & 14696.1 & 242.4 & 80.02 & 62.53 & 99.96 \\
\hline 30 & 28430.8 & 16704.7 & 11820.6 & 14607.8 & 251.6 & 81.93 & 66.11 & 99.36 \\
\hline 32 & 28585.7 & 16990.6 & 12138.9 & 14504.9 & 257.3 & 83.33 & 67.89 & 98.66 \\
\hline 36 & 29163.7 & 17553.5 & 12644.5 & 14330.0 & 269.3 & 86.09 & 70.72 & 97.47 \\
\hline 39 & 29267.4 & 17923.8 & 13246.7 & 14032.7 & 275.8 & 87.90 & 74.09 & 95.45 \\
\hline 42 & 29369.1 & 18223.1 & 13768.5 & 13741.6 & 281.8 & 89.37 & 77.01 & 93.47 \\
\hline 45 & 29463.8 & 18506.9 & 14336.7 & 13415.9 & 287.3 & 90.76 & 80.18 & 91.25 \\
\hline 48 & 29553.1 & 18789.7 & 14781.9 & 13003.0 & 292.5 & 92.15 & 82.67 & 88.44 \\
\hline 51 & 29639.6 & 19083.0 & 15294.2 & 12608.5 & 297.4 & 93.59 & 85.54 & 85.76 \\
\hline 54 & 29740.2 & 19293.3 & 15776.0 & 12204.8 & 301.9 & 94.62 & 88.23 & 83.02 \\
\hline 57 & 29845.4 & 19477.9 & 16122.9 & 11794.9 & 306.3 & 95.53 & 90.17 & 80.23 \\
\hline 60 & 29942.9 & 19634.5 & 16444.8 & 11342.0 & 310.3 & 96.29 & 91.97 & 77.15 \\
\hline 63 & 30054.3 & 19771.2 & 16710.4 & 10892.5 & 314.1 & 96.96 & 93.46 & 74.09 \\
\hline 66 & 30167.3 & 19884.9 & 16913.6 & 10418.9 & 317.7 & 97.52 & 94.60 & 70.87 \\
\hline 69 & 30275.8 & 20043.3 & 17150.1 & 9965.2 & 321.0 & 98.30 & 95.92 & 67.78 \\
\hline 72 & 30383.6 & 20169.3 & 17309.9 & 9541.8 & 324.3 & 98.92 & 96.81 & 64.90 \\
\hline 75 & 30510.7 & 20247.1 & 17493.1 & 8991.8 & 327.3 & 99.30 & 97.84 & 61.16 \\
\hline 78.5 & 30621.5 & 20237.3 & 17622.3 & 8424.6 & 330.2 & 99.25 & 98.56 & 57.30 \\
\hline 81 & 30782.64 & 20363.55 & 17737.8 & 8276.33 & 335.78 & 99.87 & 99.21 & 56.29 \\
\hline 84 & 30930.1 & 20390.1 & 17879.78 & 7936.32 & 339.58 & 100.00 & 100.00 & 53.98 \\
\hline
\end{tabular}


Table 14A. Weighted usable area for bull trout, chinook salmon, steelhead trout life stages, and cover for juvenile life stages, site VC2, middle Valley Creek, 2003-Continued

\section{STEELHEAD}

\begin{tabular}{|c|c|c|c|c|c|c|c|c|}
\hline \multirow{2}{*}{$\begin{array}{c}\text { Discharge } \\
\left(\mathrm{ft}^{3} / \mathrm{s}\right)\end{array}$} & \multirow{2}{*}{$\begin{array}{l}\text { Total Area } \\
\quad\left(\mathrm{ft}^{2}\right)\end{array}$} & \multicolumn{4}{|c|}{ Summary of Weighted Usable Area $\left(\mathrm{ft}^{2} / 1000 \mathrm{ft}\right)$} & \multicolumn{3}{|c|}{ Percent of Optimum } \\
\hline & & Adult & Spawning & Juvenile & Cover & Adult & Spawning & Juvenile \\
\hline 15 & 26003.4 & 13883.2 & 7025.5 & 19891.5 & 109.2 & 68.09 & 39.29 & 88.04 \\
\hline 18 & 26550.5 & 14454.6 & 8491.0 & 20539.6 & 119.2 & 70.89 & 47.49 & 90.91 \\
\hline 22.3 & 27328.5 & 15440.5 & 9921.3 & 21263.4 & 137.0 & 75.73 & 55.49 & 94.11 \\
\hline 24 & 27681.3 & 15877.4 & 10366.3 & 21599.3 & 143.9 & 77.87 & 57.98 & 95.60 \\
\hline 27 & 28119.3 & 16316.5 & 11180.5 & 22048.4 & 153.4 & 80.02 & 62.53 & 97.59 \\
\hline 30 & 28430.8 & 16704.7 & 11820.6 & 22312.6 & 158.0 & 81.93 & 66.11 & 98.76 \\
\hline 32 & 28585.7 & 16990.6 & 12138.9 & 22471.4 & 160.9 & 83.33 & 67.89 & 99.46 \\
\hline 36 & 29163.7 & 17553.5 & 12644.5 & 22593.5 & 167.0 & 86.09 & 70.72 & 100.00 \\
\hline 39 & 29267.4 & 17923.8 & 13246.7 & 22439.3 & 170.5 & 87.90 & 74.09 & 99.32 \\
\hline 42 & 29369.1 & 18223.1 & 13768.5 & 22170.6 & 173.8 & 89.37 & 77.01 & 98.13 \\
\hline 45 & 29463.8 & 18506.9 & 14336.7 & 21898.9 & 176.9 & 90.76 & 80.18 & 96.93 \\
\hline 48 & 29553.1 & 18789.7 & 14781.9 & 21426.9 & 181.6 & 92.15 & 82.67 & 94.84 \\
\hline 51 & 29639.6 & 19083.0 & 15294.2 & 20930.4 & 185.9 & 93.59 & 85.54 & 92.64 \\
\hline 54 & 29740.2 & 19293.3 & 15776.0 & 20324.0 & 189.8 & 94.62 & 88.23 & 89.96 \\
\hline 57 & 29845.4 & 19477.9 & 16122.9 & 19633.7 & 193.5 & 95.53 & 90.17 & 86.90 \\
\hline 60 & 29942.9 & 19634.5 & 16444.8 & 18486.3 & 196.8 & 96.29 & 91.97 & 81.82 \\
\hline 63 & 30054.3 & 19771.2 & 16710.4 & 17331.1 & 199.1 & 96.96 & 93.46 & 76.71 \\
\hline 66 & 30167.3 & 19884.9 & 16913.6 & 16235.4 & 201.4 & 97.52 & 94.60 & 71.86 \\
\hline 69 & 30275.8 & 20043.3 & 17150.1 & 15057.3 & 202.7 & 98.30 & 95.92 & 66.64 \\
\hline 72 & 30383.6 & 20169.3 & 17309.9 & 13945.5 & 203.6 & 98.92 & 96.81 & 61.72 \\
\hline 75 & 30510.7 & 20247.1 & 17493.1 & 12402.3 & 204.4 & 99.30 & 97.84 & 54.89 \\
\hline 78.5 & 30621.5 & 20237.3 & 17622.3 & 11318.2 & 204.4 & 99.25 & 98.56 & 50.10 \\
\hline 81 & 30782.6 & 20363.6 & 17737.8 & 11081.2 & 230.4 & 99.87 & 99.21 & 49.05 \\
\hline 84 & 30930.1 & 20390.1 & 17879.8 & 10432.2 & 243.3 & 100.00 & 100.00 & 46.17 \\
\hline
\end{tabular}


Figure 64A

Percent of Contiguous Stream Width

Middle Valley Creek - VC2

Passage Transect 1 (wide moderate slope)

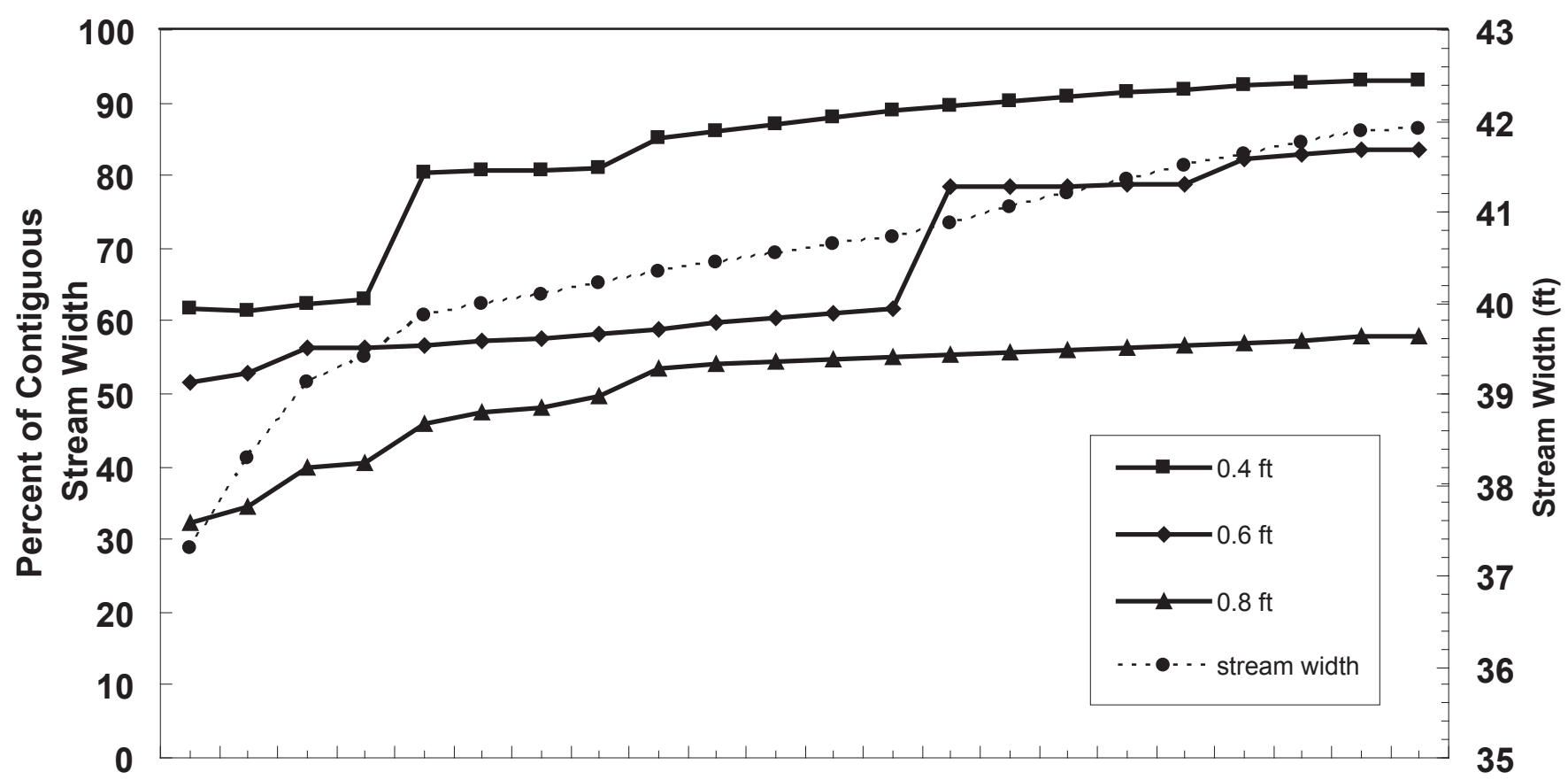

$\begin{array}{llllllllllllllllllllll}15 & 18 & 22 & 24 & 27 & 30 & 32 & 36 & 39 & 42 & 45 & 48 & 51 & 54 & 57 & 60 & 63 & 66 & 69 & 72 & 75 & 79\end{array}$

Discharge $\left(\mathrm{ft}^{3} / \mathrm{s}\right)$ 
Figure 65A

Percent of Total Stream Width

Middle Valley Creek - VC2

Passage Transect 1 (wide moderate slope)

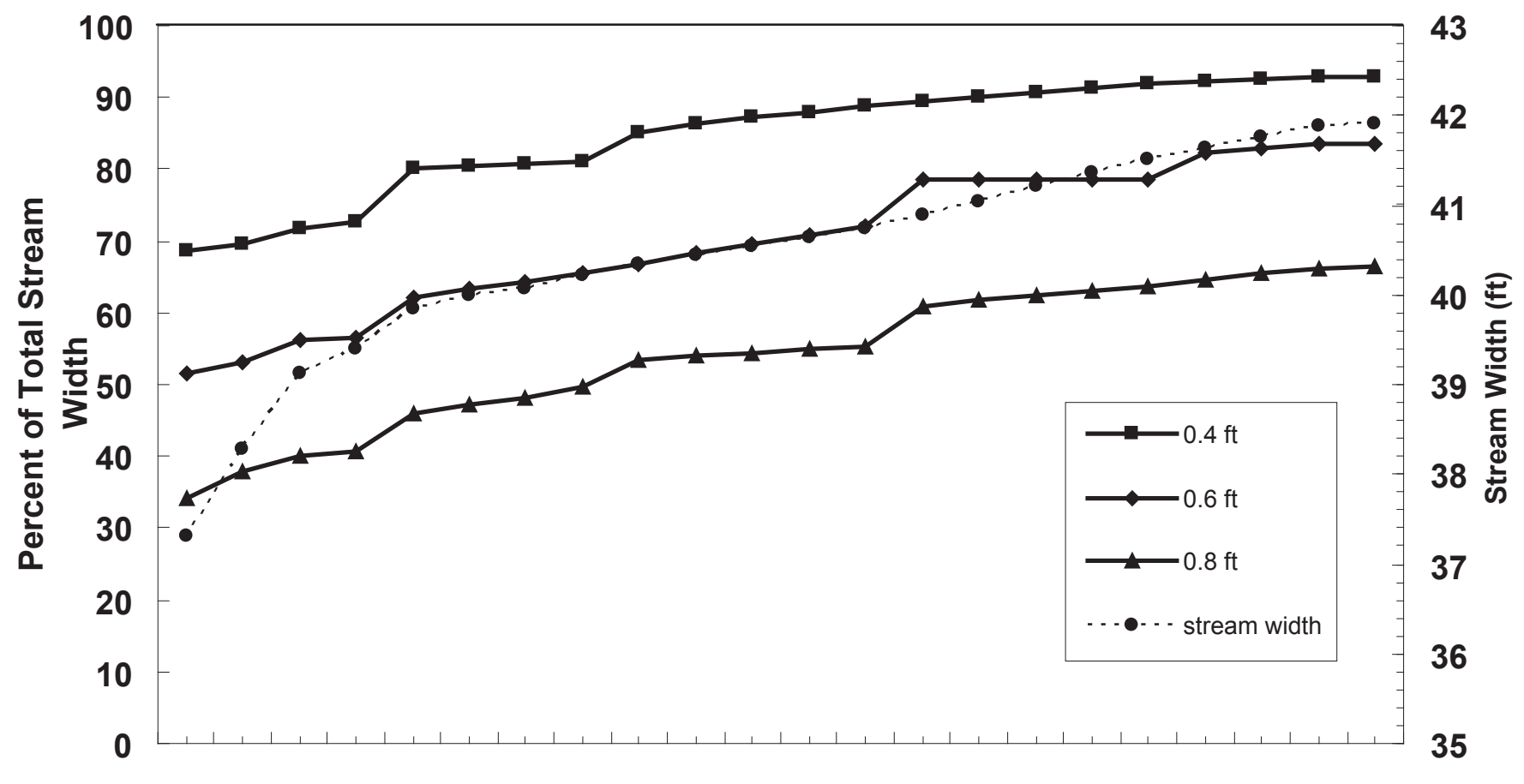

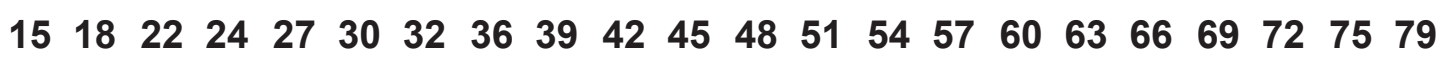

Discharge $\left(\mathrm{ft}^{3} / \mathrm{s}\right)$ 
Table 15A. Passage criteria assessment for transect 1 (wide moderate slope), site VC2, middle Valley Creek, 2003

\begin{tabular}{|c|c|c|c|c|c|}
\hline $\begin{array}{c}\text { Discharge } \\
\left(\mathrm{ft}^{3} / \mathrm{s}\right)\end{array}$ & $\begin{array}{l}\text { Stream width } \\
(\mathrm{ft})\end{array}$ & $\begin{array}{c}\text { Total Stream } \\
\text { Width Greater } \\
\text { Than } 0.4 \mathrm{ft} \text { depth }\end{array}$ & $\begin{array}{l}\text { Percent Stream } \\
\text { Width Greater } \\
\text { Than } 0.4 \mathrm{ft} \text { Depth }\end{array}$ & $\begin{array}{l}\text { Contiguous Stream } \\
\text { Width Greater Than } \\
0.4 \mathrm{ft} \text { Depth }\end{array}$ & $\begin{array}{l}\text { Percent Contiguous } \\
\text { Stream Width Greater } \\
\text { Than } 0.4 \mathrm{ft} \text { Depth }\end{array}$ \\
\hline 15 & 37.32 & 25.66 & 68.77 & 23.05 & 61.78 \\
\hline 18 & 38.28 & 26.65 & 69.62 & 23.55 & 61.51 \\
\hline 22.3 & 39.11 & 28.11 & 71.87 & 24.42 & 62.45 \\
\hline 24 & 39.41 & 28.65 & 72.71 & 24.75 & 62.82 \\
\hline 27 & 39.86 & 31.99 & 80.26 & 31.99 & 80.26 \\
\hline 30 & 39.99 & 32.23 & 80.59 & 32.23 & 80.59 \\
\hline 32 & 40.08 & 32.38 & 80.79 & 32.38 & 80.79 \\
\hline 36 & 40.23 & 32.64 & 81.15 & 32.64 & 81.15 \\
\hline 39 & 40.34 & 34.34 & 85.14 & 34.34 & 85.14 \\
\hline 42 & 40.45 & 34.86 & 86.19 & 34.86 & 86.19 \\
\hline 45 & 40.55 & 35.34 & 87.15 & 35.34 & 87.15 \\
\hline 48 & 40.64 & 35.77 & 88.01 & 35.77 & 88.01 \\
\hline 51 & 40.73 & 36.20 & 88.88 & 36.20 & 88.88 \\
\hline 54 & 40.88 & 36.62 & 89.58 & 36.62 & 89.58 \\
\hline 57 & 41.05 & 37.03 & 90.21 & 37.03 & 90.21 \\
\hline 60 & 41.20 & 37.40 & 90.77 & 37.40 & 90.77 \\
\hline 63 & 41.36 & 37.77 & 91.32 & 37.77 & 91.32 \\
\hline 66 & 41.50 & 38.12 & 91.84 & 38.12 & 91.84 \\
\hline 69 & 41.64 & 38.44 & 92.32 & 38.44 & 92.32 \\
\hline 72 & 41.77 & 38.69 & 92.64 & 38.69 & 92.64 \\
\hline 75 & 41.88 & 38.92 & 92.94 & 38.92 & 92.94 \\
\hline 78.5 & 41.90 & 38.97 & 93.00 & 38.97 & 93.00 \\
\hline 81 & 42.11 & 39.38 & 93.52 & 39.38 & 93.52 \\
\hline 84 & 42.21 & 39.58 & 93.78 & 39.58 & 93.78 \\
\hline
\end{tabular}


Table 15A. Passage criteria assessment for transect 1 (wide moderate slope), site VC2, middle Valley Creek, 2003-Continued

\begin{tabular}{|c|c|c|c|c|c|}
\hline $\begin{array}{l}\text { Discharge } \\
\qquad\left(\mathrm{ft}^{3} / \mathrm{s}\right)\end{array}$ & $\begin{array}{c}\text { Stream width } \\
(\mathbf{f t})\end{array}$ & $\begin{array}{c}\text { Total Stream } \\
\text { Width Greater } \\
\text { Than } 0.6 \mathrm{ft} \text { Depth }\end{array}$ & $\begin{array}{l}\text { Percent Stream } \\
\text { Width Greater } \\
\text { Than } 0.6 \text { ft Depth }\end{array}$ & $\begin{array}{c}\text { Contiguous Stream } \\
\text { Width Greater Than } \\
0.6 \mathrm{ft} \text { Depth }\end{array}$ & $\begin{array}{l}\text { Percent Contiguous } \\
\text { Stream Width Greate } \\
\text { Than } 0.6 \mathrm{ft} \text { Depth }\end{array}$ \\
\hline 15 & 37.32 & 19.26 & 51.60 & 19.26 & 51.60 \\
\hline 18 & 38.28 & 20.29 & 53.00 & 20.29 & 53.00 \\
\hline 22.3 & 39.11 & 22.03 & 56.31 & 22.03 & 56.31 \\
\hline 24 & 39.41 & 22.23 & 56.43 & 22.23 & 56.43 \\
\hline 27 & 39.86 & 24.71 & 62.01 & 22.58 & 56.66 \\
\hline 30 & 39.99 & 25.35 & 63.37 & 22.90 & 57.25 \\
\hline 32 & 40.08 & 25.72 & 64.19 & 23.09 & 57.60 \\
\hline 36 & 40.23 & 26.42 & 65.68 & 23.43 & 58.25 \\
\hline 39 & 40.34 & 26.97 & 66.87 & 23.73 & 58.83 \\
\hline 42 & 40.45 & 27.62 & 68.30 & 24.13 & 59.65 \\
\hline 45 & 40.55 & 28.22 & 69.60 & 24.49 & 60.40 \\
\hline 48 & 40.64 & 28.76 & 70.77 & 24.82 & 61.08 \\
\hline 51 & 40.73 & 29.30 & 71.94 & 25.15 & 61.75 \\
\hline 54 & 40.88 & 32.08 & 78.47 & 32.08 & 78.47 \\
\hline 57 & 41.05 & 32.24 & 78.54 & 32.24 & 78.54 \\
\hline 60 & 41.20 & 32.38 & 78.60 & 32.38 & 78.60 \\
\hline 63 & 41.36 & 32.53 & 78.65 & 32.53 & 78.65 \\
\hline 66 & 41.50 & 32.67 & 78.71 & 32.67 & 78.71 \\
\hline 69 & 41.64 & 34.26 & 82.26 & 34.26 & 82.26 \\
\hline 72 & 41.77 & 34.62 & 82.90 & 34.62 & 82.90 \\
\hline 75 & 41.88 & 34.97 & 83.50 & 34.97 & 83.50 \\
\hline 78.5 & 41.90 & 35.03 & 83.61 & 35.03 & 83.61 \\
\hline 81 & 42.11 & 35.64 & 84.64 & 35.64 & 84.64 \\
\hline 84 & 42.21 & 35.94 & 85.15 & 35.94 & 85.15 \\
\hline
\end{tabular}


Table 15A. Passage criteria assessment for transect 1 (wide moderate slope), site VC2, middle Valley Creek, 2003—Continued

\begin{tabular}{|c|c|c|c|c|c|}
\hline $\begin{array}{c}\text { Discharge } \\
\left(\mathrm{ft}^{3} / \mathrm{s}\right)\end{array}$ & $\begin{array}{l}\text { Stream width } \\
(\mathrm{ft})\end{array}$ & $\begin{array}{l}\text { Total Stream } \\
\text { Width Greater } \\
\text { Than } 0.8 \mathrm{ft} \text { Depth }\end{array}$ & $\begin{array}{l}\text { Percent Stream } \\
\text { Width Greater } \\
\text { Than } 0.8 \mathrm{ft} \text { Depth }\end{array}$ & $\begin{array}{l}\text { Contiguous Stream } \\
\text { Width Greater Than } \\
0.8 \mathrm{ft} \text { Depth }\end{array}$ & $\begin{array}{l}\text { Percent Contiguous } \\
\text { Stream Width Greater } \\
\text { Than } 0.8 \mathrm{ft} \text { Depth }\end{array}$ \\
\hline 15 & 37.32 & 12.75 & 34.16 & 12.05 & 32.30 \\
\hline 18 & 38.28 & 14.56 & 38.03 & 13.18 & 34.43 \\
\hline 22.3 & 39.11 & 15.62 & 39.95 & 15.62 & 39.95 \\
\hline 24 & 39.41 & 15.97 & 40.54 & 15.97 & 40.54 \\
\hline 27 & 39.86 & 18.27 & 45.83 & 18.27 & 45.83 \\
\hline 30 & 39.99 & 18.93 & 47.32 & 18.93 & 47.32 \\
\hline 32 & 40.08 & 19.32 & 48.21 & 19.32 & 48.21 \\
\hline 36 & 40.23 & 20.05 & 49.84 & 20.05 & 49.84 \\
\hline 39 & 40.34 & 21.58 & 53.51 & 21.58 & 53.51 \\
\hline 42 & 40.45 & 21.84 & 53.99 & 21.84 & 53.99 \\
\hline 45 & 40.55 & 22.07 & 54.42 & 22.07 & 54.42 \\
\hline 48 & 40.64 & 22.28 & 54.82 & 22.28 & 54.82 \\
\hline 51 & 40.73 & 22.49 & 55.21 & 22.49 & 55.21 \\
\hline 54 & 40.88 & 24.94 & 61.02 & 22.70 & 55.52 \\
\hline 57 & 41.05 & 25.37 & 61.80 & 22.91 & 55.80 \\
\hline 60 & 41.20 & 25.75 & 62.49 & 23.10 & 56.05 \\
\hline 63 & 41.36 & 26.12 & 63.17 & 23.28 & 56.30 \\
\hline 66 & 41.50 & 26.48 & 63.81 & 23.46 & 56.53 \\
\hline 69 & 41.64 & 26.87 & 64.51 & 23.67 & 56.83 \\
\hline 72 & 41.77 & 27.33 & 65.42 & 23.95 & 57.33 \\
\hline 75 & 41.88 & 27.76 & 66.28 & 24.21 & 57.81 \\
\hline 78.5 & 41.90 & 27.84 & 66.44 & 24.26 & 57.89 \\
\hline 81 & 42.11 & 28.60 & 67.92 & 24.72 & 58.71 \\
\hline 84 & 42.21 & 28.98 & 68.65 & 24.95 & 59.12 \\
\hline
\end{tabular}




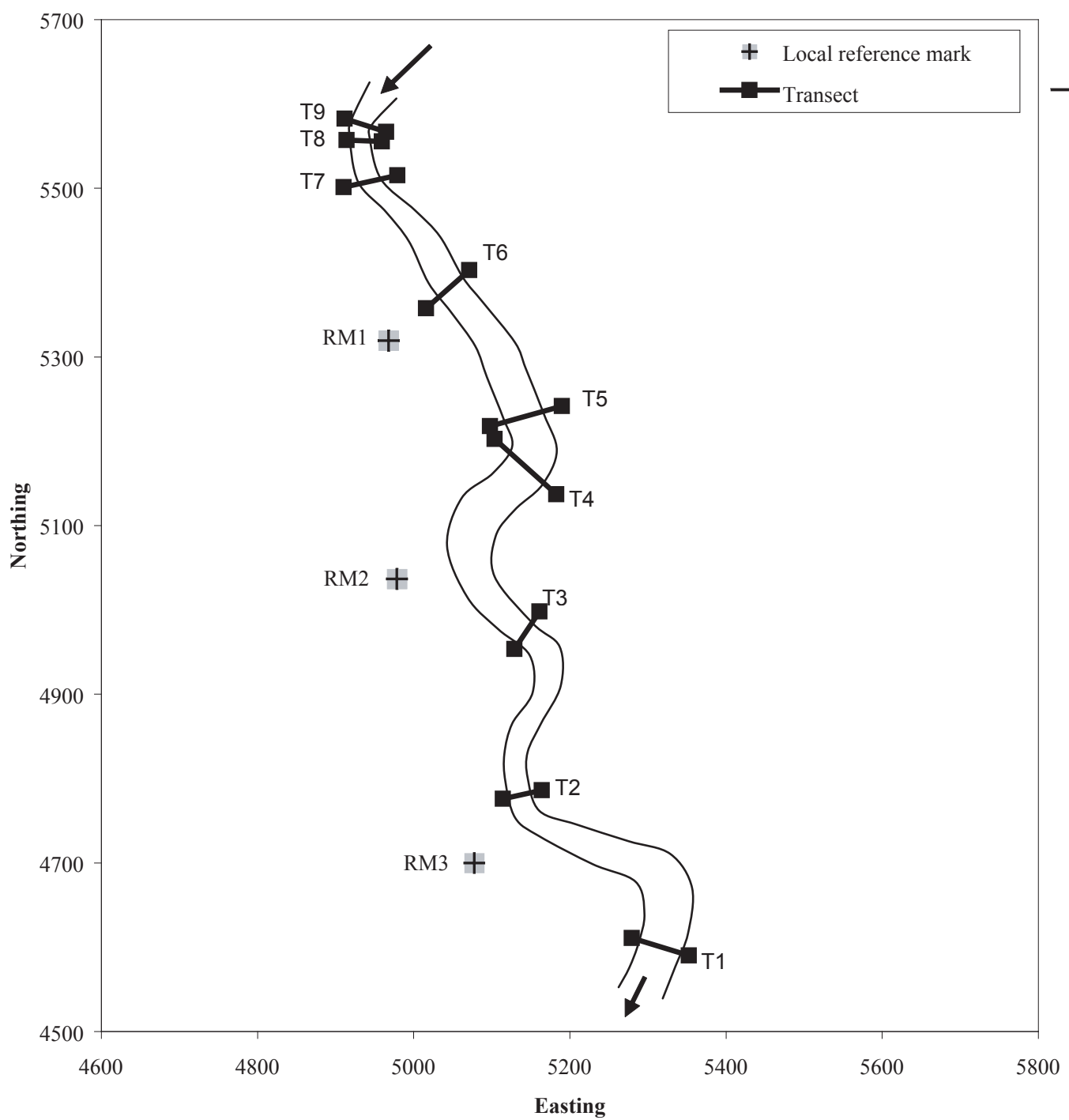

Transect Endpoint Coordinates (NAD 83)

Point Latitude Longitude

LB T1 $115^{\circ} 00^{\prime} 22.86^{\prime \prime} \mathrm{W} \quad 44^{\circ} 16^{\prime} 1.36^{\prime \prime} \mathrm{N}$

RB T1 $115^{\circ} 0^{\prime} 21.86^{\prime \prime} \mathrm{W} \quad 44^{\circ} 16^{\prime} 1.15^{\prime \prime} \mathrm{N}$

LB T2 $115^{\circ} 0^{\prime} 24.60^{\prime \prime} \mathrm{W} \quad 44^{\circ} 16^{\prime} 2.73^{\prime \prime} \mathrm{N}$

RB T2 $115^{\circ} 0^{\prime} 24.43^{\prime \prime} \mathrm{W} \quad 44^{\circ} 16^{\prime} 3.10^{\prime \prime} \mathrm{N}$

LB T3 $115^{\circ} 0^{\prime} 24.88^{\prime \prime} \mathrm{W} \quad 44^{\circ} 16^{\prime} 4.76^{\prime \prime} \mathrm{N}$

RB T3 $115^{\circ} 0^{\prime} 24.44^{\prime \prime} \mathrm{W} \quad 44^{\circ} 16^{\prime} 5.19^{\prime \prime} \mathrm{N}$

LB T4 $115^{\circ} 0^{\prime} 25.20^{\prime \prime} \mathrm{W} \quad 44^{\circ} 16^{\prime} 7.22^{\prime \prime} \mathrm{N}$

RB T4 $115^{\circ} 0^{\prime} 24.12^{\prime \prime} \mathrm{W} \quad 44^{\circ} 16^{\prime} 6.57^{\prime \prime} \mathrm{N}$

LB T5 $115^{\circ} 0^{\prime} 25.28^{\prime \prime} \mathrm{W} \quad 44^{\circ} 16^{\prime} 7.37^{\prime \prime} \mathrm{N}$

RB T5 $115^{\circ} 0^{\prime} 24.01^{\prime \prime} \mathrm{W} \quad 44^{\circ} 16^{\prime} 7.60^{\prime \prime} \mathrm{N}$

LB T6 $115^{\circ} 0^{\prime} 26.38^{\prime \prime} \mathrm{W} \quad 44^{\circ} 16^{\prime} 8.75^{\prime \prime} \mathrm{N}$

RB T6 $115^{\circ} 0^{\prime} 25.62^{\prime \prime} \mathrm{W} \quad 44^{\circ} 16^{\prime} 9.20^{\prime \prime} \mathrm{N}$

LB T7 $115^{\circ} 0^{\prime} 27.81^{\prime \prime} \mathrm{W} \quad 44^{\circ} 16^{\prime} 10.18^{\prime \prime} \mathrm{N}$

RB T7 $115^{\circ} 0^{\prime} 26.86^{\prime \prime} \mathrm{W} \quad 44^{\circ} 16^{\prime} 10.32^{\prime \prime} \mathrm{N}$

LB T8 $115^{\circ} 0^{\prime} 27.75^{\prime \prime} \mathrm{W} \quad 44^{\circ} 16^{\prime} 10.73^{\prime \prime} \mathrm{N}$

RB T8 $115^{\circ} 0^{\prime} 27.13^{\prime \prime} \mathrm{W} \quad 44^{\circ} 16^{\prime} 10.71{ }^{\prime \prime} \mathrm{N}$

LB T9 $115^{\circ} 0^{\prime} 27.78^{\prime \prime} \mathrm{W} \quad 44^{\circ} 16^{\prime} 10.99^{\prime \prime} \mathrm{N}$

RB T9 $115^{\circ} 0^{\prime} 27.05^{\prime \prime} \mathrm{W} \quad 44^{\circ} 16^{\prime} 10.82^{\prime \prime} \mathrm{N}$

For reference only; stream schematic not to scale.

Figure 66A

Lower Valley Creek - VC1

Plan View 
Figure 67A

Lower Valley Creek - VC1

Bull Trout WUA

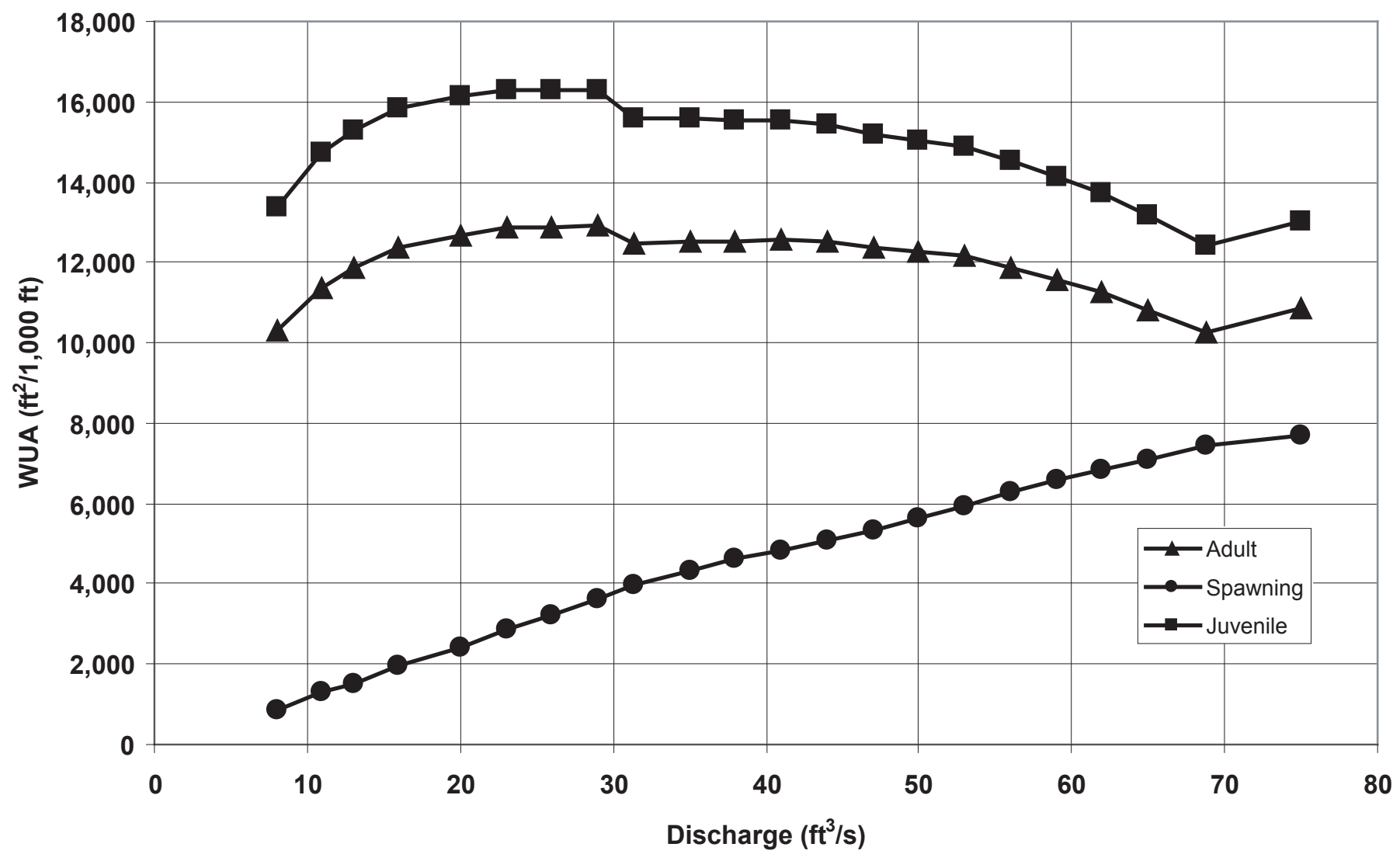


Figure 68A

Lower Valley Creek - VC1

Bull Trout WUA Normalized

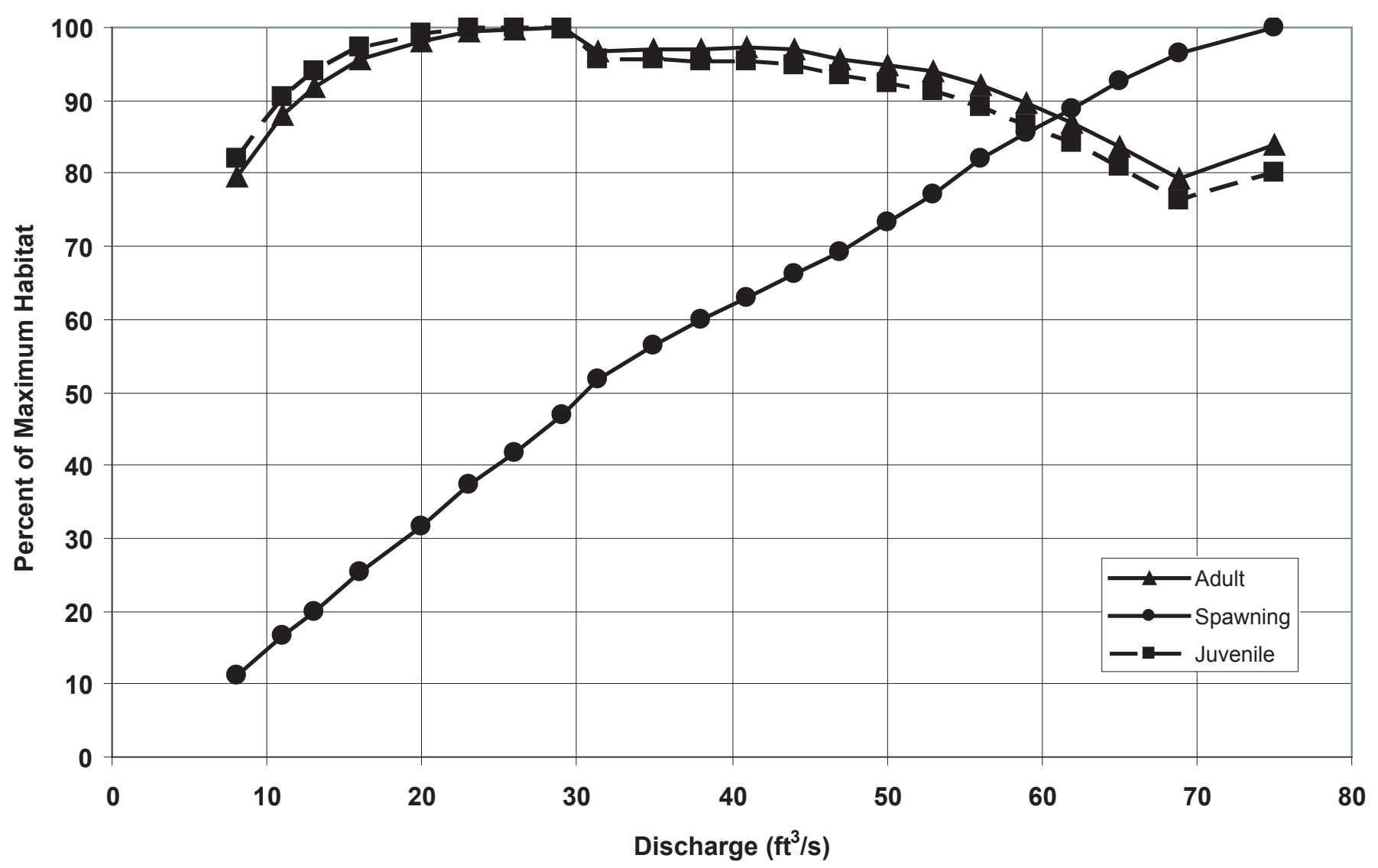


Figure 69A

Lower Valley Creek - VC1

Chinook Salmon WUA

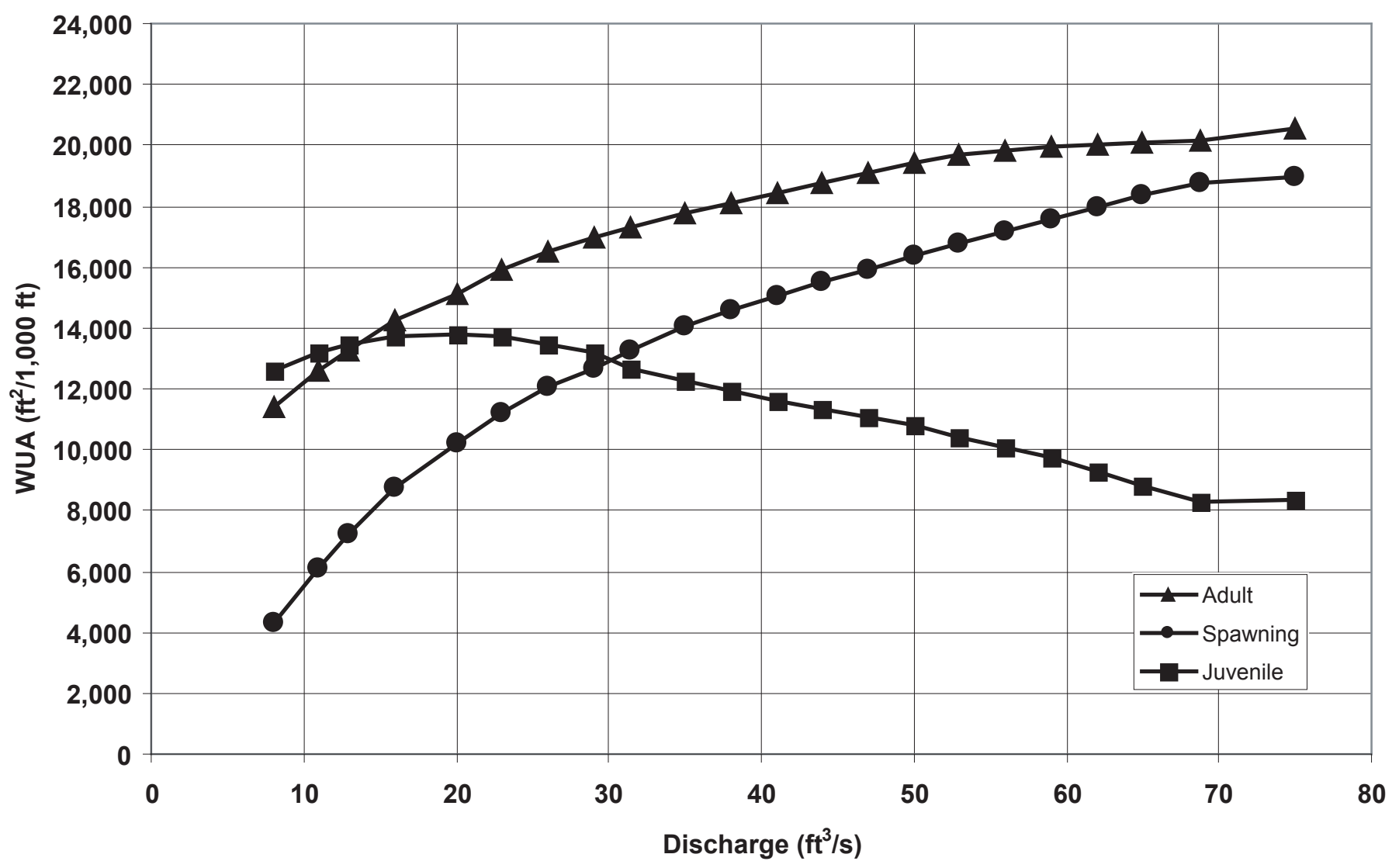


Figure 70A

Lower Valley Creek - VC1

Chinook Salmon WUA Normalized

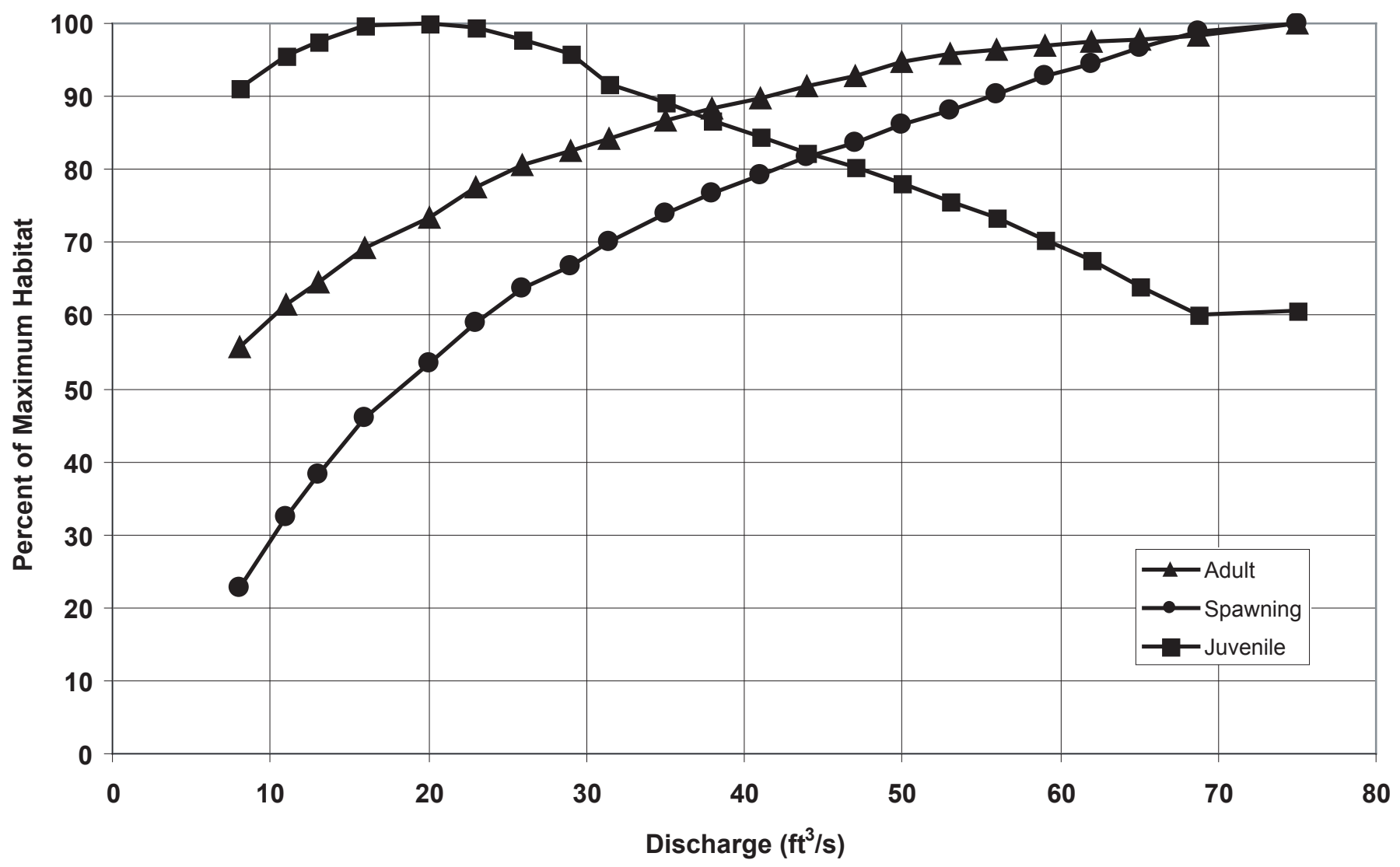

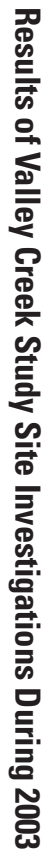


Figure 71A

Lower Valley Creek - VC1

Steelhead WUA

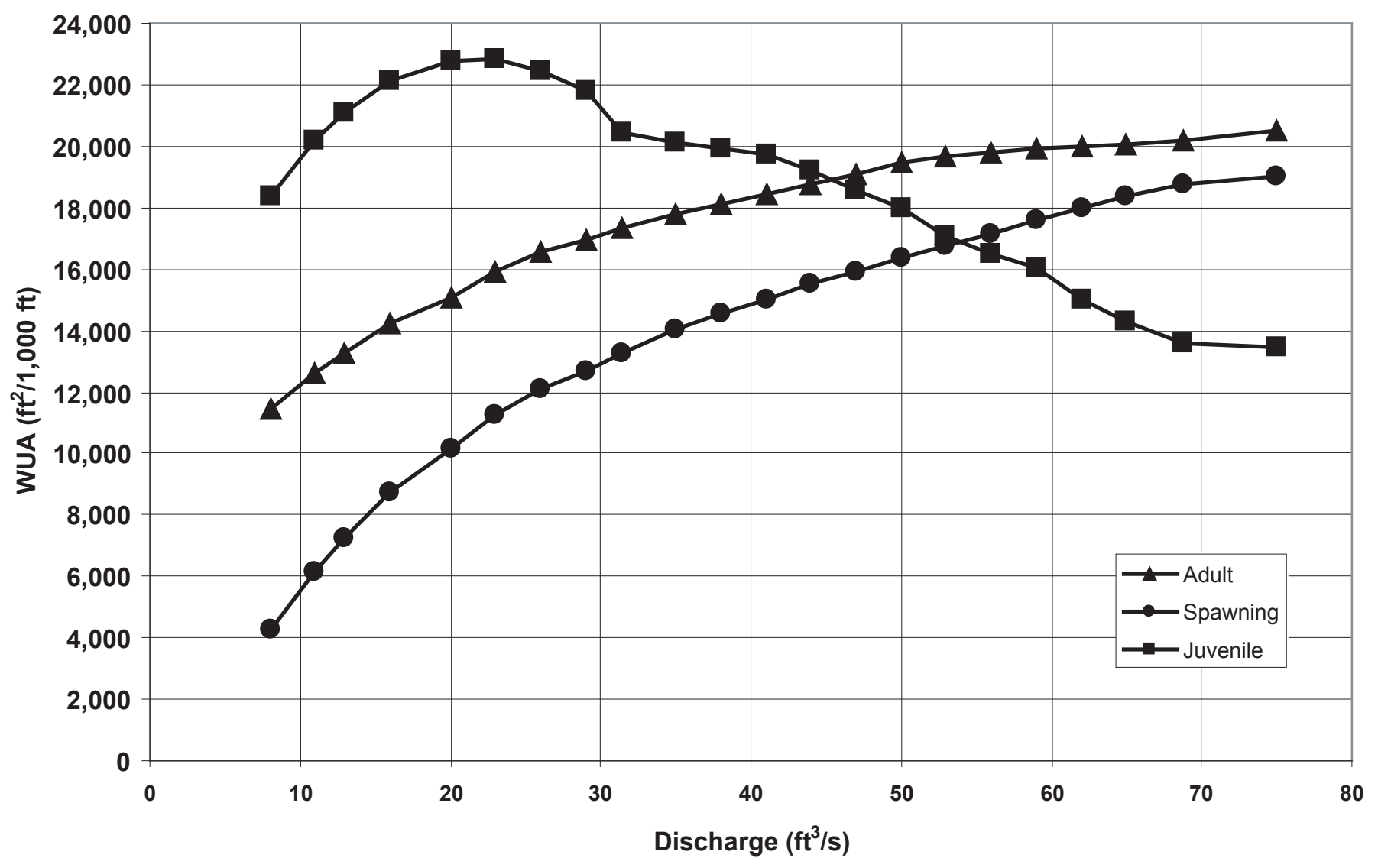


Figure 72A

Lower Valley Creek - VC1

Steelhead WUA Normalized

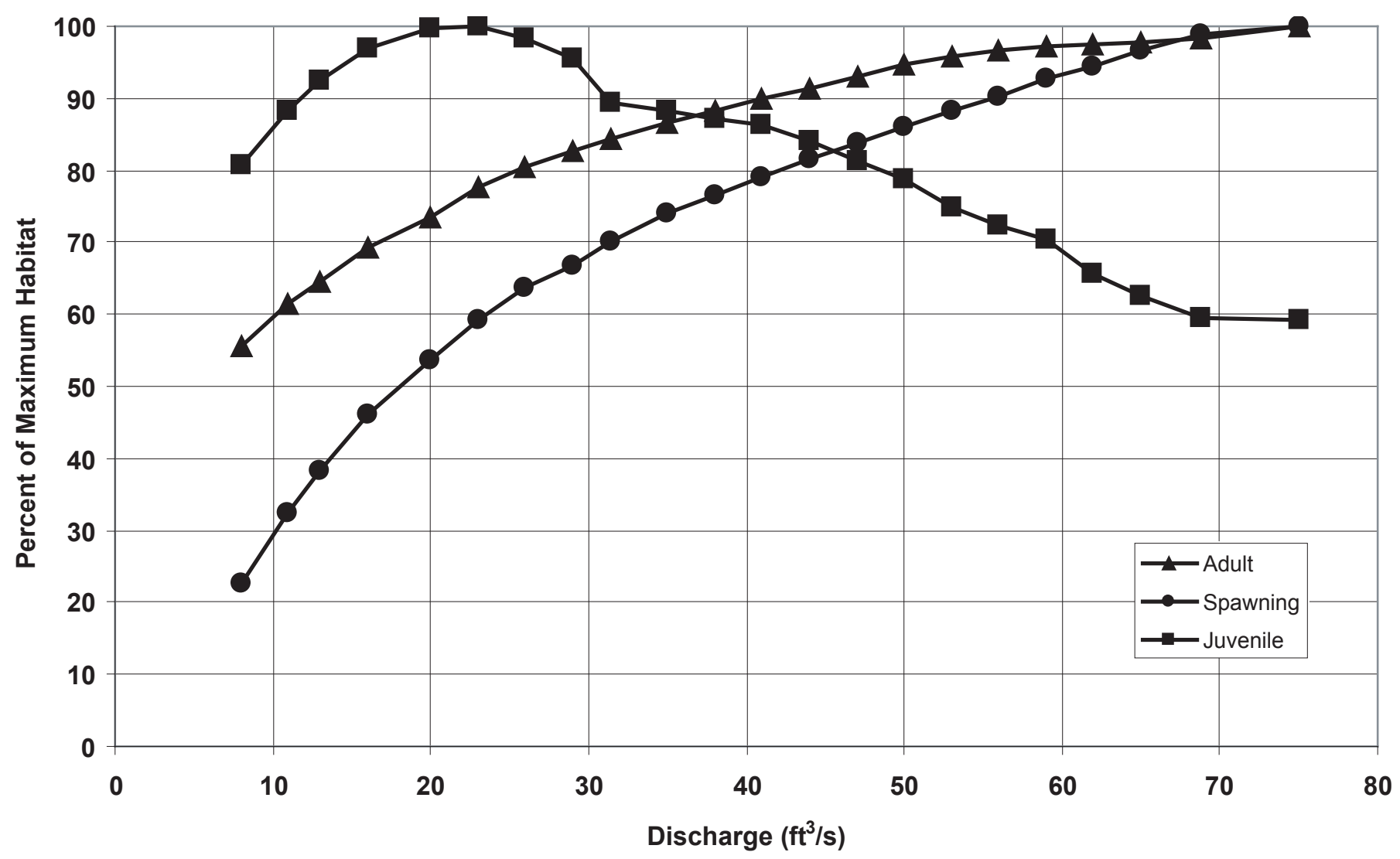


Table 16A. Weighted usable area for bull trout, chinook salmon, steelhead trout life stages, and cover for juvenile life stages, site VC1, lower Valley Creek, 2003

\section{BULL TROUT}

\begin{tabular}{|c|c|c|c|c|c|c|c|c|}
\hline \multirow{2}{*}{$\begin{array}{c}\text { Discharge } \\
\left(\mathrm{ft}^{3} / \mathrm{s}\right)\end{array}$} & \multirow{2}{*}{$\begin{array}{c}\text { Total Area } \\
\left(\mathrm{ft}^{2}\right)\end{array}$} & \multicolumn{4}{|c|}{ Summary of Weighted Usable Area $\left(\mathrm{ft}^{2} / 1000 \mathrm{ft}\right.$ ) } & \multicolumn{3}{|c|}{ Percent of Optimum } \\
\hline & & Adult & Spawning & Juvenile & Cover & Adult & Spawning & Juvenile \\
\hline 8 & 28040.5 & 10294.1 & 864.1 & 13379.8 & 442.7 & 79.62 & 11.25 & 82.15 \\
\hline 11 & 29074.1 & 11379.7 & 1284.8 & 14723.8 & 486.2 & 88.02 & 16.73 & 90.40 \\
\hline 13 & 29768.4 & 11856.8 & 1526.5 & 15294.5 & 504.3 & 91.71 & 19.88 & 93.90 \\
\hline 16 & 30983.9 & 12372.9 & 1938.4 & 15858.0 & 529.0 & 95.70 & 25.24 & 97.36 \\
\hline 20 & 32008.4 & 12685.0 & 2433.7 & 16149.5 & 545.6 & 98.11 & 31.69 & 99.15 \\
\hline 23 & 32616.5 & 12849.3 & 2859.5 & 16287.6 & 550.0 & 99.39 & 37.23 & 100.00 \\
\hline 26 & 33003.6 & 12895.5 & 3203.5 & 16286.3 & 594.6 & 99.74 & 41.71 & 99.99 \\
\hline 29 & 33349.0 & 12928.8 & 3602.4 & 16268.0 & 691.0 & 100.00 & 46.91 & 99.88 \\
\hline 31.4 & 34175.4 & 12494.3 & 3983.2 & 15592.3 & 748.3 & 96.64 & 51.87 & 95.73 \\
\hline 35 & 34566.3 & 12537.7 & 4332.5 & 15594.6 & 762.3 & 96.97 & 56.41 & 95.74 \\
\hline 38 & 34821.6 & 12539.7 & 4604.3 & 15543.6 & 745.9 & 96.99 & 59.95 & 95.43 \\
\hline 41 & 35062.3 & 12578.9 & 4836.6 & 15548.0 & 745.2 & 97.29 & 62.98 & 95.46 \\
\hline 44 & 35292.4 & 12535.5 & 5086.7 & 15451.5 & 729.2 & 96.96 & 66.23 & 94.87 \\
\hline 47 & 35511.1 & 12370.0 & 5310.2 & 15200.6 & 694.6 & 95.68 & 69.14 & 93.33 \\
\hline 50 & 35715.7 & 12262.8 & 5623.7 & 15038.3 & 691.4 & 94.85 & 73.23 & 92.33 \\
\hline 53 & 35911.1 & 12147.5 & 5917.4 & 14873.4 & 683.1 & 93.96 & 77.05 & 91.32 \\
\hline 56 & 36090.8 & 11890.2 & 6288.9 & 14523.9 & 668.5 & 91.97 & 81.89 & 89.17 \\
\hline 59 & 36262.5 & 11578.2 & 6571.1 & 14122.9 & 643.7 & 89.55 & 85.56 & 86.71 \\
\hline 62 & 36424.8 & 11246.5 & 6826.9 & 13716.0 & 591.6 & 86.99 & 88.89 & 84.21 \\
\hline 65 & 36574.6 & 10826.6 & 7111.9 & 13182.7 & 521.2 & 83.74 & 92.60 & 80.94 \\
\hline 68.8 & 37354.65 & 10267.7 & 7417.0 & 12433.9 & 460.0 & 79.42 & 96.58 & 76.34 \\
\hline 75 & 37958.25 & 10846.08 & 7680.0 & 13039.4 & 430.0 & 83.89 & 100.00 & 80.06 \\
\hline
\end{tabular}


Table 16A. Weighted usable area for bull trout, chinook salmon, steelhead trout life stages, and cover for juvenile life stages, site VC1, lower Valley Creek, 2003-Continued

\section{CHINOOK TROUT}

\begin{tabular}{lcccccccc}
\begin{tabular}{c} 
Discharge \\
\multicolumn{1}{c}{$\left.\mathbf{f t}^{3} \mathbf{s} \mathbf{s}\right)$}
\end{tabular} & $\begin{array}{c}\text { Total Area } \\
\left(\mathbf{f t}^{2}\right)\end{array}$ & \multicolumn{2}{c}{ Summary of Weighted Usable Area $\left(\mathbf{f t}^{2} / \mathbf{1 0 0 0} \mathbf{f t}\right)$} & \multicolumn{3}{c}{ Percent of Optimum } \\
8 & Adult & Spawning & Juvenile & Cover & Adult & Spawning & Juvenile \\
11 & 28040.47 & 11417.9 & 4301.6 & 12568.1 & 396.5 & 55.60 & 22.65 & 91.19 \\
13 & 29074.12 & 12609.0 & 6131.9 & 13178.5 & 442.5 & 61.40 & 32.28 & 95.61 \\
16 & 29768.38 & 13238.1 & 7251.3 & 13429.5 & 471.9 & 64.46 & 38.18 & 97.44 \\
20 & 30983.88 & 14247.6 & 8730.3 & 13740.3 & 513.9 & 69.38 & 45.96 & 99.69 \\
23 & 32008.38 & 15086.0 & 10180.6 & 13782.9 & 546.9 & 73.46 & 53.60 & 100.00 \\
26 & 32616.52 & 15924.3 & 11229.0 & 13706.8 & 563.2 & 77.54 & 59.12 & 99.45 \\
29 & 33003.61 & 16532.9 & 12075.1 & 13481.5 & 570.6 & 80.50 & 63.57 & 97.81 \\
31.4 & 33348.97 & 16971.9 & 12679.4 & 13209.2 & 570.9 & 82.64 & 66.76 & 95.84 \\
35 & 34175.37 & 17306.5 & 13290.5 & 12645.7 & 588.7 & 84.27 & 69.97 & 91.75 \\
38 & 34566.32 & 17789.5 & 14059.2 & 12295.1 & 586.3 & 86.62 & 74.02 & 89.21 \\
41 & 34821.64 & 18122.8 & 14559.6 & 11965.3 & 581.1 & 88.25 & 76.66 & 86.81 \\
44 & 35062.3 & 18453.5 & 15037.5 & 11633.8 & 571.0 & 89.86 & 79.17 & 84.41 \\
47 & 35292.43 & 18769.1 & 15507.6 & 11340.4 & 557.0 & 91.39 & 81.65 & 82.28 \\
50 & 35511.06 & 19080.0 & 15902.8 & 11077.5 & 540.8 & 92.91 & 83.73 & 80.37 \\
53 & 35715.73 & 19448.9 & 16346.1 & 10783.3 & 520.4 & 94.70 & 86.06 & 78.24 \\
56 & 35911.05 & 19661.8 & 16748.0 & 10440.6 & 494.6 & 95.74 & 88.18 & 75.75 \\
59 & 36090.75 & 19824.2 & 17140.6 & 10098.7 & 475.9 & 96.53 & 90.24 & 73.27 \\
62 & 36262.53 & 19934.8 & 17599.5 & 9713.7 & 448.6 & 97.07 & 92.66 & 70.48 \\
65 & 36424.79 & 20020.7 & 17958.1 & 9297.8 & 419.3 & 97.49 & 94.55 & 67.46 \\
68.8 & 36574.63 & 20084.3 & 18340.2 & 8828.5 & 400.5 & 97.80 & 96.56 & 64.05 \\
75 & 37354.6 & 20186.9 & 18760.5 & 8266.2 & 364.1 & 98.30 & 98.77 & 59.97 \\
& 37958.3 & 20536.6 & 18993.6 & 8368.6 & 331.3 & 100.00 & 100.00 & 60.72
\end{tabular}


Table 16A. Weighted usable area for bull trout, chinook salmon, steelhead trout life stages, and cover for juvenile life stages, site VC1, lower Valley Creek, 2003-Continued

\section{STEELHEAD}

\begin{tabular}{|c|c|c|c|c|c|c|c|c|}
\hline \multirow{2}{*}{$\begin{array}{c}\text { Discharge } \\
\left(\mathrm{ft}^{3} / \mathrm{s}\right)\end{array}$} & \multirow{2}{*}{$\begin{array}{c}\text { Total Area } \\
\left(\mathrm{ft}^{2}\right)\end{array}$} & \multicolumn{4}{|c|}{ Summary of Weighted Usable Area ( $\left.\mathrm{ft}^{2} / 1000 \mathrm{ft}\right)$} & \multicolumn{3}{|c|}{ Percent of Optimum } \\
\hline & & Adult & Spawning & Juvenile & Cover & Adult & Spawning & Juvenile \\
\hline 8 & 28040.5 & 11417.9 & 4301.6 & 18396.1 & 435.0 & 55.60 & 22.65 & 80.64 \\
\hline 11 & 29074.1 & 12609.0 & 6131.9 & 20153.6 & 502.6 & 61.40 & 32.28 & 88.35 \\
\hline 13 & 29768.4 & 13238.1 & 7251.3 & 21101.4 & 538.8 & 64.46 & 38.18 & 92.50 \\
\hline 16 & 30983.9 & 14247.6 & 8730.3 & 22110.7 & 591.6 & 69.38 & 45.96 & 96.93 \\
\hline 20 & 32008.4 & 15086.0 & 10180.6 & 22752.5 & 690.0 & 73.46 & 53.60 & 99.74 \\
\hline 23 & 32616.5 & 15924.3 & 11229.0 & 22812.0 & 734.9 & 77.54 & 59.12 & 100.00 \\
\hline 26 & 33003.6 & 16532.9 & 12075.1 & 22458.0 & 771.6 & 80.50 & 63.57 & 98.45 \\
\hline 29 & 33349.0 & 16971.9 & 12679.4 & 21821.2 & 805.3 & 82.64 & 66.76 & 95.66 \\
\hline 31.4 & 34175.4 & 17306.5 & 13290.5 & 20419.4 & 828.1 & 84.27 & 69.97 & 89.51 \\
\hline 35 & 34566.3 & 17789.5 & 14059.2 & 20144.6 & 834.5 & 86.62 & 74.02 & 88.31 \\
\hline 38 & 34821.6 & 18122.8 & 14559.6 & 19912.1 & 832.4 & 88.25 & 76.66 & 87.29 \\
\hline 41 & 35062.3 & 18453.5 & 15037.5 & 19719.4 & 822.5 & 89.86 & 79.17 & 86.44 \\
\hline 44 & 35292.4 & 18769.1 & 15507.6 & 19185.7 & 785.0 & 91.39 & 81.65 & 84.10 \\
\hline 47 & 35511.1 & 19080.0 & 15902.8 & 18566.8 & 772.0 & 92.91 & 83.73 & 81.39 \\
\hline 50 & 35715.7 & 19448.9 & 16346.1 & 17988.7 & 738.0 & 94.70 & 86.06 & 78.86 \\
\hline 53 & 35911.1 & 19661.8 & 16748.0 & 17046.9 & 648.8 & 95.74 & 88.18 & 74.73 \\
\hline 56 & 36090.8 & 19824.2 & 17140.6 & 16475.3 & 612.6 & 96.53 & 90.24 & 72.22 \\
\hline 59 & 36262.5 & 19934.8 & 17599.5 & 16033.3 & 554.0 & 97.07 & 92.66 & 70.28 \\
\hline 62 & 36424.8 & 20020.7 & 17958.1 & 14985.8 & 520.2 & 97.49 & 94.55 & 65.69 \\
\hline 65 & 36574.6 & 20084.3 & 18340.2 & 14290.9 & 455.9 & 97.80 & 96.56 & 62.65 \\
\hline 68.8 & 37354.6 & 20186.9 & 18760.5 & 13580.8 & 339.1 & 98.30 & 98.77 & 59.53 \\
\hline 75 & 37958.3 & 20536.6 & 18993.6 & 13479.5 & 276.1 & 100.00 & 100.00 & 59.09 \\
\hline
\end{tabular}


Figure 73A

Percent of Contiguous Stream Width

Lower Valley Creek - VC1

Passage Transect 4 (wide low slope)

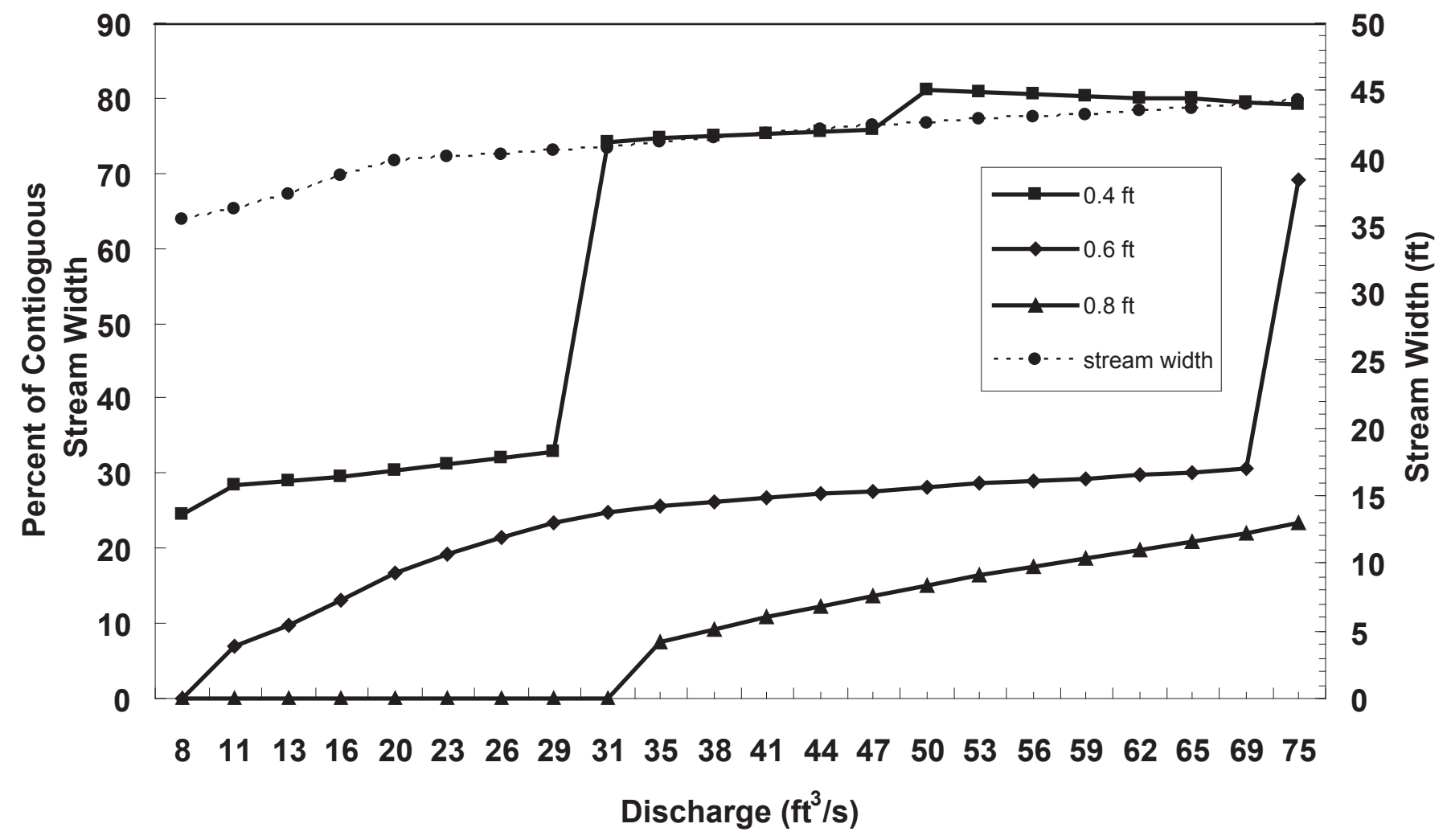


Figure 74A

Percent of Total Stream Width

Lower Valley Creek - VC1

Passage Transect 4 (wide low slope)

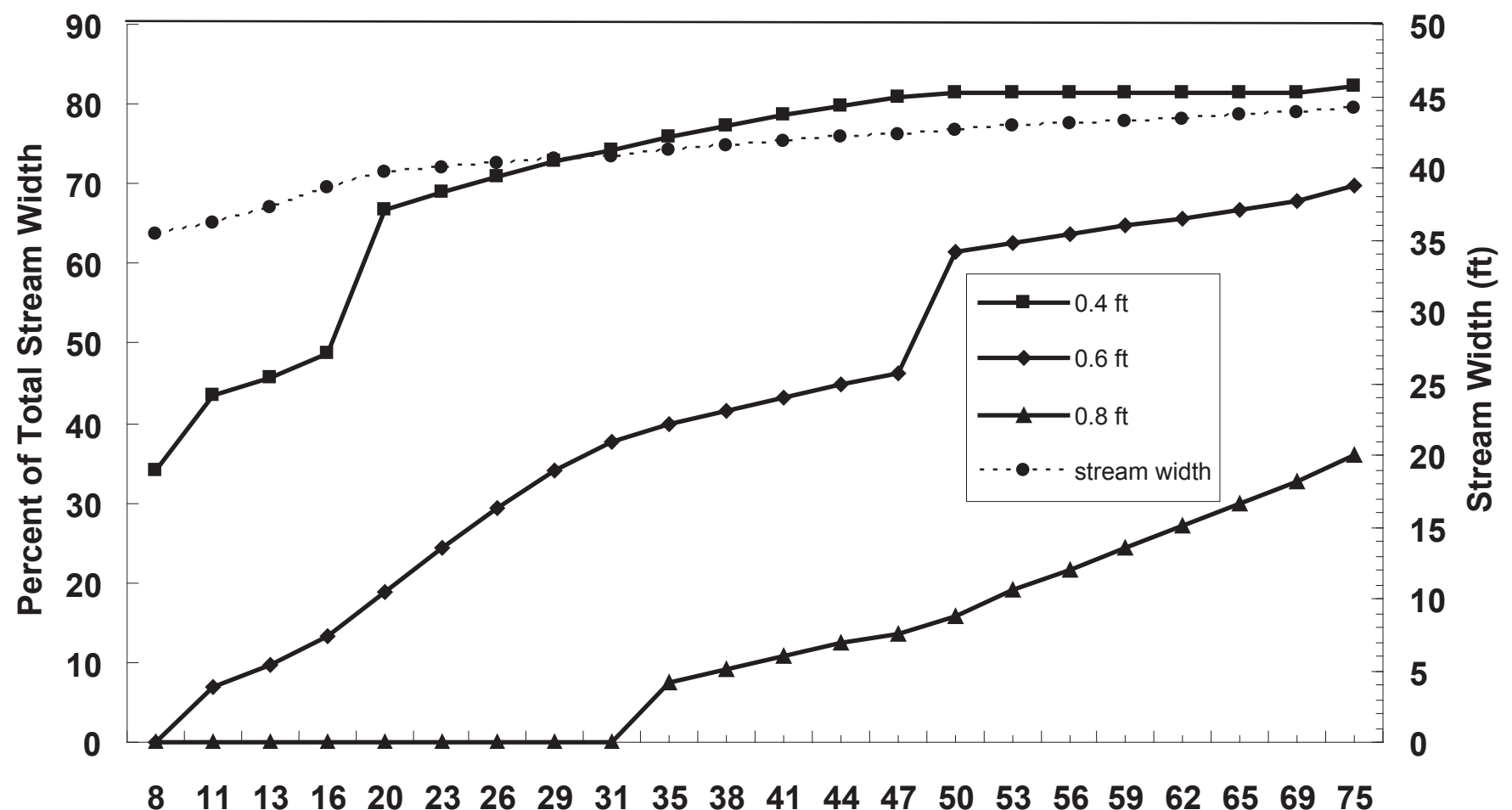

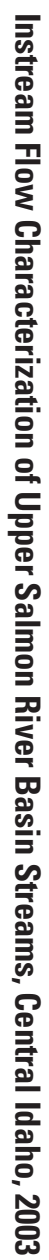

$\begin{array}{llllllllllllllllllllll}8 & 11 & 13 & 16 & 20 & 23 & 26 & 29 & 31 & 35 & 38 & 41 & 44 & 47 & 50 & 53 & 56 & 59 & 62 & 65 & 69 & 75\end{array}$ Discharge ( $\left.\mathrm{ft}^{3} / \mathrm{s}\right)$ 
Table 17A. Passage criteria assessment for transect 4 (wide low slope), site VC1, lower Valley Creek, 2003

\begin{tabular}{|c|c|c|c|c|c|}
\hline $\begin{array}{c}\text { Discharge } \\
\left(\mathrm{ft}^{3} / \mathrm{s}\right)\end{array}$ & $\begin{array}{c}\text { Stream width } \\
(\mathbf{f t})\end{array}$ & $\begin{array}{c}\text { Total Stream } \\
\text { Width Greater } \\
\text { Than } 0.4 \text { ft depth }\end{array}$ & $\begin{array}{l}\text { Percent Stream } \\
\text { Width Greater } \\
\text { Than } 0.4 \text { ft Depth }\end{array}$ & $\begin{array}{c}\text { Contiguous Stream } \\
\text { Width Greater Than } \\
0.4 \mathrm{ft} \text { Depth }\end{array}$ & $\begin{array}{l}\text { Percent Contiguous } \\
\text { Stream Width Greater } \\
\text { Than } 0.4 \mathrm{ft} \text { Depth }\end{array}$ \\
\hline 8 & 35.37 & 12.07 & 34.12 & 8.70 & 24.59 \\
\hline 11 & 36.20 & 15.77 & 43.56 & 10.28 & 28.40 \\
\hline 13 & 37.24 & 17.05 & 45.79 & 10.76 & 28.89 \\
\hline 16 & 38.64 & 18.78 & 48.60 & 11.41 & 29.52 \\
\hline 20 & 39.77 & 26.51 & 66.66 & 12.11 & 30.45 \\
\hline 23 & 40.05 & 27.58 & 68.88 & 12.54 & 31.32 \\
\hline 26 & 40.30 & 28.58 & 70.91 & 12.95 & 32.12 \\
\hline 29 & 40.54 & 29.50 & 72.76 & 13.32 & 32.85 \\
\hline 31.4 & 40.73 & 30.20 & 74.16 & 30.20 & 74.16 \\
\hline 35 & 41.17 & 31.29 & 76.00 & 30.72 & 74.63 \\
\hline 38 & 41.47 & 32.04 & 77.25 & 31.08 & 74.95 \\
\hline 41 & 41.78 & 32.80 & 78.51 & 31.45 & 75.27 \\
\hline 44 & 42.10 & 33.57 & 79.76 & 31.82 & 75.59 \\
\hline 47 & 42.37 & 34.24 & 80.81 & 32.14 & 75.87 \\
\hline 50 & 42.62 & 34.66 & 81.33 & 34.60 & 81.18 \\
\hline 53 & 42.85 & 34.85 & 81.32 & 34.66 & 80.88 \\
\hline 56 & 43.05 & 35.01 & 81.32 & 34.71 & 80.62 \\
\hline 59 & 43.26 & 35.17 & 81.31 & 34.76 & 80.35 \\
\hline 62 & 43.46 & 35.33 & 81.31 & 34.81 & 80.10 \\
\hline 65 & 43.67 & 35.50 & 81.30 & 34.86 & 79.83 \\
\hline 68.8 & 43.90 & 35.69 & 81.29 & 34.92 & 79.55 \\
\hline 75 & 44.22 & 36.34 & 82.19 & 35.01 & 79.18 \\
\hline $\begin{array}{c}\text { Discharge } \\
\left(\mathrm{ft}^{3} / \mathrm{s}\right)\end{array}$ & $\begin{array}{c}\text { Stream width } \\
\text { (ft) }\end{array}$ & $\begin{array}{c}\text { Total Stream } \\
\text { Width Greater } \\
\text { Than } 0.6 \mathrm{ft} \text { depth }\end{array}$ & $\begin{array}{l}\text { Percent Stream } \\
\text { Width Greater } \\
\text { Than } 0.6 \mathrm{ft} \text { Depth }\end{array}$ & $\begin{array}{c}\text { Contiguous Stream } \\
\text { Width Greater Than } \\
0.6 \mathrm{ft} \text { Depth }\end{array}$ & $\begin{array}{l}\text { Percent Contiguous } \\
\text { Stream Width Greater } \\
\text { Than } 0.6 \mathrm{ft} \text { Depth }\end{array}$ \\
\hline 8 & 35.37 & 0.00 & 0.00 & 0.00 & 0.00 \\
\hline 11 & 36.20 & 2.51 & 6.94 & 2.51 & 6.94 \\
\hline 13 & 37.24 & 3.61 & 9.69 & 3.61 & 9.69 \\
\hline 16 & 38.64 & 5.09 & 13.16 & 5.09 & 13.16 \\
\hline 20 & 39.77 & 7.46 & 18.77 & 6.69 & 16.83 \\
\hline 23 & 40.05 & 9.74 & 24.32 & 7.68 & 19.19 \\
\hline 26 & 40.30 & 11.85 & 29.41 & 8.61 & 21.35 \\
\hline 29 & 40.54 & 13.80 & 34.03 & 9.45 & 23.32 \\
\hline 31.4 & 40.73 & 15.28 & 37.53 & 10.10 & 24.80 \\
\hline 35 & 41.17 & 16.45 & 39.95 & 10.53 & 25.59 \\
\hline 38 & 41.47 & 17.25 & 41.60 & 10.84 & 26.13 \\
\hline 41 & 41.78 & 18.08 & 43.26 & 11.14 & 26.67 \\
\hline 44 & 42.10 & 18.90 & 44.90 & 11.45 & 27.21 \\
\hline 47 & 42.37 & 19.61 & 46.29 & 11.72 & 27.66 \\
\hline 50 & 42.62 & 26.19 & 61.46 & 11.98 & 28.11 \\
\hline 53 & 42.85 & 26.84 & 62.65 & 12.25 & 28.58 \\
\hline 56 & 43.05 & 27.40 & 63.65 & 12.47 & 28.96 \\
\hline 59 & 43.26 & 27.98 & 64.69 & 12.70 & 29.37 \\
\hline 62 & 43.46 & 28.54 & 65.68 & 12.93 & 29.76 \\
\hline 65 & 43.67 & 29.14 & 66.73 & 13.17 & 30.16 \\
\hline 68.8 & 43.90 & 29.78 & 67.84 & 13.43 & 30.59 \\
\hline 75 & 44.22 & 30.82 & 69.69 & 30.50 & 68.97 \\
\hline
\end{tabular}


Table 17A. Passage criteria assessment for transect 4 (wide low slope), site VC1, lower Valley Creek, 2003—Continued

$\begin{array}{cccccc}\begin{array}{c}\text { Discharge } \\ \left(\mathbf{f t}^{3} \mathbf{s}\right)\end{array} & \begin{array}{c}\text { Stream width } \\ (\mathbf{f t})\end{array} & \begin{array}{c}\text { Total Stream } \\ \text { Width Greater } \\ \text { Than } \mathbf{0 . 8} \mathbf{f t} \text { depth }\end{array} & \begin{array}{c}\text { Percent Stream } \\ \text { Width Greater } \\ \text { Than } \mathbf{0 . 8} \mathbf{f t} \text { Depth }\end{array} & \begin{array}{c}\text { Contiguous Stream } \\ \text { Width Greater Than } \\ \mathbf{0 . 8} \mathbf{f t} \text { Depth }\end{array} & \begin{array}{c}\text { Percent Contiguous } \\ \text { Stream Width Greater } \\ \text { Than } \mathbf{0 . 8} \mathbf{f t} \text { Depth }\end{array} \\ 8 & 35.37 & 0.00 & 0.00 & 0.00 & 0.00 \\ 11 & 36.20 & 0.00 & 0.00 & 0.00 & 0.00 \\ 13 & 37.24 & 0.00 & 0.00 & 0.00 & 0.00 \\ 16 & 38.64 & 0.00 & 0.00 & 0.00 & 0.00 \\ 20 & 39.77 & 0.00 & 0.00 & 0.00 & 0.00 \\ 23 & 40.05 & 0.00 & 0.00 & 0.00 & 0.00 \\ 26 & 40.30 & 0.00 & 0.00 & 0.00 & 0.00 \\ 29 & 40.54 & 0.00 & 0.00 & 0.00 & 0.00 \\ 31.4 & 40.73 & 0.00 & 0.00 & 0.00 & 0.00 \\ 35 & 41.17 & 3.09 & 7.52 & 3.09 & 7.52 \\ 38 & 41.47 & 3.78 & 9.12 & 3.78 & 10.74 \\ 41 & 41.78 & 4.49 & 10.74 & 4.49 & 12.33 \\ 44 & 42.10 & 5.19 & 12.33 & 5.19 & 13.68 \\ 47 & 42.37 & 5.80 & 13.68 & 5.80 & 15.01 \\ 50 & 42.62 & 6.78 & 15.92 & 6.40 & 16.34 \\ 53 & 42.85 & 8.17 & 19.07 & 7.00 & 17.46 \\ 56 & 43.05 & 9.35 & 21.71 & 7.51 & 18.61 \\ 59 & 43.26 & 10.58 & 24.46 & 8.05 & 19.72 \\ 62 & 43.46 & 11.77 & 27.09 & 8.57 & 20.89 \\ 65 & 43.67 & 13.04 & 29.85 & 9.12 & 22.12 \\ 68.8 & 43.90 & 14.39 & 32.78 & 9.71 & 23.40 \\ 75 & 44.22 & 15.94 & 36.06 & 10.35 & \end{array}$


Manuscript approved for publication, July 7, 2004.

Manuscript released on World Wide Web, December 2004, at URL: http://id.water.usgs.gov/public/reports.html

Prepared by U.S. Geological Survey Publishing staff, Idaho District, Boise, Idaho:

Launa H. Allen

Linda K. Channel

Linda Buckmaster

Richard L. Helton

For more information concerning the research in this report, contact:

Idaho District Chief

U.S. Geological Survey

230 Collins Road

Boise, Idaho 83702-4520

http://id.water.usgs.gov 
